Universidade de São Paulo

Instituto de Psicologia

Sandra Maria Patrício Ribeiro

\title{
ANATOMIA SOCIAL DE UM CRIME EM FAMÍLIA \\ Estudo psicossocial sobre a dialética dos discursos e representações sobre família, afetos, homens e mortes.
}

Dissertação apresentada ao Instituto de Psicologia da Universidade de São Paulo, como parte dos requisitos para obtenção do título de Mestre em Psicologia.

Área de Concentração: Psicologia Social e do Trabalho

Orientadora: Profa. Dra. Sueli Damergian

São Paulo 


\section{ANATOMIA SOCIAL DE UM CRIME EM FAMÍLIA}

Estudo psicossocial sobre a dialética dos discursos e representações sobre família, afetos, homens e mortes.

Sandra Maria Patrício Ribeiro

BANCA EXAMINADORA:

Prof ${ }^{\mathrm{a}} \mathrm{Dr}^{\mathrm{a}}$ Sueli Damergian (Orientadora)

Prof $^{a}$ Dr $^{\mathrm{a}}$ Eda Terezinha de Oliveira Tassara

Prof. Dr. Luiz Carlos Rocha

Dissertação defendida e aprovada em: 28/08/2001 
Porque a matéria-prima deste trabalho custou-lhes a todos o sacrifício de suas vidas, fica pesarosamente dedicado a

Mário,

Karin,

Roberto,

Cristina,

Paulo e

André. 


\section{Índice}

Resumo/ Abstract 5

Agradecimentos 7

Preâmbulo 8

\section{Parte Teórica}

Capítulo 1. O trabalho de teorizar sobre homicídios 25

O trabalho arqueológico de descobrir fábulas $\quad 32$

O trabalho genealógico de compreender fábulas $\mathbf{3 8}$

O trabalho ético de contar uma nova fábula 52

O trabalho fabuloso de construir um método para a psicologia social 57

Estudo de Caso

Capítulo 2. As confabulações sociais sobre homicídios violentos 66

Capítulo 3. Roberto e sua família... 95

Capítulo 4. Roberto, o patri-matri-fratricida... 107

Capítulo 5. O Estado contra Roberto 114

O incompreensível Roberto... 121

Roberto, o epiléptico condutopata... 127

Roberto, o assassino torpe... 135

Capítulo 6. Roberto, o monstro da zona sul. 144

\section{(In) conclusões}

Capítulo 7. As confabulações psi sobre os homicidas violentos 174

Feldman e os componentes hereditários da personalidade 178

Paiva e as origens do tanatismo 194

Palomba e a epilepsia condutopática 211

Notas para um novo modo de confabular dentro do campo psi 237

Capítulo 8. Um ensaio sobre homicidas e homens fabulosos 249

Bibliografia 269

Anexos 273 


\section{Resumo}

O presente estudo versa sobre os discursos policial, jurídico, psiquiátrico e jornalístico produzidos acerca de um jovem, autor de um quíntuplo homicídio em família (patri-matri-fratricídio). O dossier sobre o caso, e ainda mais três explicações para a conduta violenta, oriundas do campo psi, foram analisados a partir da arqueologia, genealogia e ética foucaultianas visando esclarecer os motivos e os modos de construção destes discursos. O estudo permitiu constatar que as diferentes instâncias sociais solidarizaram-se para forjar uma representação do homicida compatível com o consagrado modelo da psicopatia - a ausência de remorsos, a incapacidade para a empatia, a frieza afetiva e a insensibilidade moral; também, que produções do campo psi prestam-se a dar referendo científico às colusões sociais que retratam os homicidas como seres malígnos, portadores de aberrações biológicas que os incapacitam a desenvolver adequadamente a afetividade e a moralidade, condenando-os aos atos criminosos violentos. Estas constatações, discutidas pelo prisma das contradições da sociedade contemporânea, deixam vislumbrar parte daquilo que se obnubila por estes discursos: remetendo ao plano biológico as determinações da conduta irracional e violenta, poupa-se de crítica o ordenamento sistemático das relações sócio-econômicas. Em conclusão, apresenta-se como imperativo derivar para a ciência psi a injunção de conhecer e denunciar as interveniências dos planos individual e coletivo em toda e qualquer conduta humana - o mais irracional e violento dos crimes cometido por um homem, guarda obrigatoriamente os traços da irracionalidade e violência do sistema social que o envolve; aperceber-se deles é condição de transformá-los. 


\begin{abstract}
This present study considers the police, legal, psychiatric and journalistic speeches about a young man who is the author of a quintuplet family homicide (patricide-matricide-fraticide). The dossier about the case, and three explanations else for the violent behaviour from the psy area, were analysed from the archaeological, genealogical and ethical foucaultian considering to clear up the cause and way these speeches were constructed.The study has allowed to show up the different social resort to join forces to forging a representation of the murderer with the stablished model of psychopath - no remorses, the incapacity for empathy, coolness affection and moral insensibility; it is also to show that productions of the psy area are suitable for giving scientific endorsement to the social agreement that show the murderer as evil beings who are owners a such of biological aberrations that make them incapable of developing the affecting and morality and to sentence them to criminal violent actions. All these observations were talked about by the point of view of the contemporany society contradictions and they let to glimpse part of that are hided by those speeches: the systematic order of social economical relations indulgences itself of criticism when it sends the determinations of irrational and violent behaviour to the biological area. As conclusion, it shows the necessity to deduce to the psy science the obligation to knowing and denouncing the interference between individual and collective plans in all human behaviour - the most of irrational and violent crimes commited by a man hides traces of irrationality and violence of social system that involves it. The capacity of see the traces is the conditions to be able to change them.
\end{abstract}




\section{Agradeço:}

Aos mestres, próximos ou remotos, no tempo ou no espaço, que iluminaram meu caminho, e a todas as pessoas que facilitaram ou incentivaram minha caminhada.

Algumas pessoas do IP-USP/PST devem ser expressamente mencionadas, porque merecem minha especial gratidão: Profa. Dra. Sueli Damergian, Profa. Dra. Eda Terezinha de Oliveira Tassara, Sra. Nalva, Srta. Cecília.

Durante a realização deste estudo, estive forçada a enfrentar adversidades de toda ordem. Alguns amigos ajudaram-me na superação de cada uma delas e sou-lhes grata por isto. À Vera Helena Ostronoff agradeço, sobretudo, o acolhimento e a fé; ao Renato Accioly, seus imoderados elogios, nem sempre justos, mas sempre animadores.

Elisabete Rodrigues contribuiu de tantas maneiras para a realização deste trabalho que sempre faltarão palavras para agradecer-lhe o bastante. Resta-me registrar meu compromisso de fraternidade, que é como posso traduzir minha gratidão por sua amizade.

Ao Marcelo e às crianças, Lívia, Enzo, Ítalo e Leon, nem é caso de agradecimento. A eles, expresso meu amor.

Ao $\mathrm{CNPq}$, pela concessão da bolsa que viabilizou minha dedicação ao estudo, meu reconhecimento. 


\section{Preâmbulo}

Preciso começar contando o que chamarei a pré-história deste estudo. Não sei quando começou. Lembro-me apenas a partir do início dos anos 80, quando trabalhava com jovens infratores na periferia de São Paulo, visando sua reintegração comunitária. Eu estava em torno dos vinte anos e alguns deles eram meus coetâneos, embora a maioria fosse adolescente e alguns ainda crianças. Esta circunstância, aliada à nossa origem e condição social comum, determinava que eu estivesse mais próxima, tanto do ponto de vista afetivo-emocional quanto do ponto de vista intelectual, daqueles rapazes e moças que do grupo de monitores que desenvolvia o trabalho - estes, em sua maioria, mais velhos, oriundos da classe média alta e com formação superior. Minha relação com eles era bastante singular, quando comparada com as relações que estabeleciam com os demais monitores; minha posição comportava suficiente ambigüidade para constituir-me em interlocutora privilegiada destes jovens infratores: eu aparecia-lhes, simultaneamente, como sua igual e como diferente. Isto, por um lado, dificultava minha comunicação no grupo de

monitores e, de certo modo, afastava minha atuação junto ao grupo de infratores das diretrizes formalizadas do trabalho. Por outro lado, propiciou contatos bastante especiais, talvez impossíveis de ocorrer noutras condições.

Algumas situações vividas durante os quatro anos que dediquei a este trabalho foram particularmente marcantes, e penso poder considerá-las como pedras fundamentais das preocupações que enfrento no presente estudo. Uma destas situações refere-se a Quincas, de 15 anos, rapaz que vendia maconha, praticava furtos e participava de roubos à mão armada nos 
bairros próximos. Já estivera preso algumas vezes nas delegacias de polícia da região e em sua última prisão havia sido submetido a intensa tortura. Outra situação marcante refere-se ao conteúdo de algumas conversas que mantive com infratores, que ilustrarei contando uma das declarações de crueldade que ouvi. Impossível relatar, quase vinte anos depois, tudo quanto me atingiu e tudo quanto presenciei nestas situações - isto precisa estar claro. Não se pode relatar um caso, mas precisamos fazê-lo e isto causa infinita confusão. Acredito poder, ao menos, alertar o leitor de que meu relato encontra-se limitado pelos meus objetivos atuais e pela minha lembrança, e esta, por sua vez, além de limitar-se pelo que eu cheguei a conhecer da vida daquelas pessoas, limita-se ainda pelo que eu era capaz de apreender na época dos fatos e pelo que fui capaz de reter ao longo destes anos. Por estas e outras razões, peço ao leitor que se abstenha de julgar as atitudes dos protagonistas destes casos, ou de avaliá-las segundo qualquer gabarito. Eles, como todos nós, naquele, como em qualquer tempo e lugar, reagiam como podiam às contingências da vida e eram, na realidade, pessoas inteiras, que jamais poderei retratar num escrito.

Assim é que, quando Estela veio pedir-me que escondesse Quincas em minha casa, pois a polícia o acuara em um matagal próximo, concordei. Eu estava bastante impressionada com as marcas das cordas em seus pulsos e tornozelos, marcas do pau-de-arara, que ele havia exibido quando fora libertado da delegacia, menos de uma semana antes. Estela providenciou para que trouxessem Quincas, e ele chegou coberto de excrementos e sanguessugas, aterrorizado. Estivera escondido durante duas horas dentro de uma valeta de esgoto, disposto a tudo para não cair novamente nas mãos da polícia. Quincas ficou em minha casa por duas ou três semanas. Neste tempo, demonstrava uma gratidão e uma humildade 
desmedidas. Era gentil e externava francamente seu agradecimento. Falava baixo, comia pouco, antecipava-se em executar as tarefas domésticas de minha casa, procurava agradar-me e ao meu marido. Foi Estela quem contou porque a polícia o perseguia: naquele dia, durante uma discussão, Quincas havia espancado sua mãe (Dejanira), e quebrado vários móveis de sua casa. Dejanira, enraivecida, informara à polícia que Quincas guardava em casa um revólver, mas imediatamente disse isto à Quincas, que saiu levando a arma. Quando os policiais chegaram, não encontrando o revólver, passaram a perseguir Quincas pelo bairro, até acuá-lo no matagal. Quincas pouco falou sobre sua mãe enquanto esteve em minha casa. Eu a procurei dois ou três dias depois, junto com outro monitor do trabalho, e passei a ter contato frequente com ela: era muito pobre, analfabeta, tivera vários companheiros e atualmente viera morar consigo um homem de emprego muito modesto que comprava parte dos mantimentos para a casa, bebia muito e desentendia-se com Quincas e seus irmãos. Parecia aliviada porque alguém estivesse assumindo o encargo de cuidar de Quincas e orientá-lo. Era visível que mãe e filho se amavam, como era visível que se odiavam. Era visível, também, que um não podia contar com o outro e que nenhum dos dois podia esforçar-se mais para cuidar do outro. Ambos, mãe e filho, sentiam-se magoados e desamparados por isto, e recriminavam-se mutuamente. Daí as brigas e os espancamentos; primeiro de Quincas por Dejanira e depois, ele crescido, de Dejanira por Quincas. A nenhum deles ocorria que estavam ambos desamparados e machucados, e que cada um deles não podia prover o outro de cuidados porque nenhum deles tinha o bastante sequer para si mesmo; que o mais esforço necessário para alterar sua condição era despropositadamente grande. Parecia-lhes a ambos que o outro recusava-se provê-lo por desamor... ou pior: por maldade. Na época, mesmo para mim era difícil compreender as origens sociais destas mágoas e deste desamparo. Quincas ainda voltou para a casa de sua mãe e 
espancou-a novamente. Ela chamou a polícia, ele foi preso e novamente torturado numa delegacia. Pela intervenção da equipe de trabalho, Quincas foi finalmente levado à Febem. Através de uma Ordem Religiosa, conseguimos que um casal estrangeiro residente no interior paulista abrigassem Quincas. Sua mãe concordou em retirá-lo da Febem, para enviá-lo a este casal. Levei Quincas até sua nova cidade e visitei-o lá algumas vezes. O casal estava ensinando Quincas a ler e escrever, e também hinos cristãos e músicas de seu país. Quincas mandava-me cartas com as letras das músicas de que gostava - todas falavam de mãe. Sentia falta dos companheiros, das drogas e da vida no bairro. Acabou voltando para a casa da mãe, e para o mesmo modo de vida de antes. Entre seus pares, como entre os monitores, cristalizou-se contra ele um tom de recriminação e de desinteresse por sua sorte, que entretanto não impedia a simpatia, convívio e bem-querença. Perdi contato com ele quando deixei o trabalho e o bairro; eu não podia esforçar-me mais para cuidar daquelas pessoas, e o quanto eu podia não era o bastante para todos nós...

Lembro-me que a convivência com estes jovens infratores frequentemente causava-me certo incômodo que, na época, não podia ser convertido em palavras. Levou tempo para compreender as indagações contidas naqueles sentimentos difusos e desconfortáveis. Nem sempre eu podia tomar consciência de muito do que experimentava no contato com eles, e nem sempre podia compartilhar com o grupo de monitores minhas experiências. Havia quase um abismo entre os dois grupos, cavado pelas histórias de vida dos membros de cada um deles. Eu pairava sobre este abismo, sem poder constituir-me em elemento articulador entre os dois mundos que se abria para cada um de seus lados; eu não era uma ponte. Não poderia sê-lo: ali mesmo onde eu via pessoas submergindo em suas 
esperanças frustradas, em seu mútuo vexame por não se poderem redimir umas às outras, nem a si mesmas; ali mesmo submergia eu própria. De igual maneira, submergia também diante da loquacidade onipotente dos monitores, que queria aplainar o caminho da redenção para todos nós.

Pude, porém, constituir-me em elemento impressionável, e recolhi histórias, sentimentos, emoções, sensações; recolhi e guardei toda uma gama de impressões deixadas pela experiência daquele período em que estive exposta sobre o abismo. Deste material pouco palpável retiro agora uma declaração de crueldade que ouvi de um rapaz. Guardei desta conversa quase tão só o afeto despertado em mim, mas guardei-o inteiro, com todas as suas nuances. Estávamos conversando, eu e um pequeno grupo de moças e rapazes, dentre os que cometiam infrações mais graves (tráfico e roubo). Este era também o grupo do qual eu estava mais próxima, pois já havia assistido vários dentre eles em situações de prisão ilegal, problemas de saúde e outras dificuldades. Nestas ocasiões, sentia-me compelida a uma dedicação que extrapolava minha função de monitora, e em muitos casos isto rendeu-me o acesso ao cotidiano destes jovens e, em alguns, também de suas famílias. Assim, sob alguns aspectos, eu era membro daquele grupo, e era comum que conversássemos por muito tempo, sobre várias coisas. Neste dia, o assunto desagüou na carreira delinqüente de cada um. Naturalmente, a maioria das histórias eram contadas para mim, que era quem as desconhecia em sua maior parte. A conversa tinha um curso intimista, e todos estavam propensos às exposições mais francas. Não lembro ao certo qual dos rapazes, à minha memória parece poder ter sido quase qualquer um deles, por isto prefiro chamá-lo Fulano, narrava um período em que roubava junto com um ou dois outros, estranhos a este grupo. Contou-nos um episódio, que disse não 
poder esquecer: certa noite, assaltaram um casal de namorados usando um revólver sem munição. Então, curraram a moça enquanto o namorado, cheio de ódio e desespero visíveis, era mantido subjugado sob a mira do revólver desmuniciado. Ninguém ali, nem eu, tínhamos palavras para deslindar nossos incômodos. Tentei sustentar a situação perguntando porque não podia esquecer aquilo. Ele repetia a constatação do ódio e desespero do rapaz subjugado, e de sua própria consciência da falta de munição na arma. Repetia: O cara foi muito otário. Mas ele não sabia, não tinha como saber. A gente via nos olhos dele, o ódio, o desespero... se ele pudesse, ele matava a gente. Dava vontade de contar...até hoje dá vontade de encontrar o cara e contar pra ele. Mas o cara não sabia, etc... Via-se nos olhos do rapaz que ele sofria com a lembrança; seu próprio rosto contraía-se do ódio e do desespero de sua vítima, mas suas palavras não podiam ir além. Ninguém se podia fitar, mais. Pareceu-me estarmos todos envergonhados da compaixão que sentíamos por Fulano, ao mesmo tempo e precisamente porque sentíamos nojo dele e compaixão pelo rapaz assaltado. A ambivalência era extrema. Não pudemos perdoar nem punir Fulano: ele se apresentara demasiadamente humano, como todos nós. Instalou-se um mal-estar angustiado; a conversa esgotou-se. Eu também não pude mais esquecer aquilo.

Passados aproximadamente cinco anos do meu desligamento daquele trabalho, iniciei o curso de graduação em psicologia. A partir de então aquele incômodo foi, paulatinamente, ganhando nitidez, recebendo nomes. Aos poucos, as perguntas foram sendo formuladas. 
Assim como não posso contar todos os sentimentos que experimentei naquele trabalho, também não há como reproduzir todas as questões que estes sentimentos suscitaram em mim. Posso apenas indicar o rumo tomado por minhas indagações: meu pensamento caminhava em busca de compreender como tornava-se possível àqueles rapazes a prática da crueldade. Não é difícil compreender a infração às normas legais de conduta, quando se conhece de perto as condições de vida daqueles jovens. Incompreensível para mim eram as condições nas quais um jovem pudesse renunciar à possibilidade de redimir-se, quando comportavam-se de maneira que feria indistintamente a todos, inclusive a seus pares na delinqüência; inclusive a si mesmos. Era isto que incomodava nas situações relatadas a pouco. Em cada uma delas, vê-se um jovem acirrar sua própria exclusão social, apartando-se da possibilidade de compreensão, amor e cuidado. Eram todos marginais, do ponto de vista sócio-econômicocultural; pela violação da lei, rápido tornavam-se marginais em meio à sua própria família e à comunidade. Mas nisto, passavam a pertencer ao grupo de pares delinqüentes, adotando sua pauta de condutas. Alguns, porém, pela prática da crueldade, tornam-se marginais aí também; tornam-se execráveis aos seus pares e aos seus próprios olhos.

É preciso dizer que espancar a mãe e currar moças, além de condutas recriminadas por toda a sociedade, são procedimentos execrados entre bandidos, e nenhum deles desconhece as regras de sua punição. Quincas e Fulano conheciam estas regras e, aparentemente, execravam também suas próprias condutas, cultivando idéias fantasiosas de reparação ou compensação, mediante a punição: Quincas mantinha-se embebido na idéia de mãe e a venerava (lembro-me de uma de suas cartas na qual, repetida numerosas vezes sobre o papel, aparecia a palavra mère, rebordada 
com linhas sinuosas, sublinhados e estampas, e ao lado de mais de uma delas sua tradução do francês, mãe. No corpo da carta contava-me que a mulher do casal com o qual residia estava ensinando a ele algumas palavras deste idioma), voltando sempre para junto da sua própria mãe real e reiniciando o ciclo de violências que culminava com ele sendo torturado na prisão; Fulano, já no momento da prática da crueldade, sentia vontade de confessar a ineficácia de sua arma, dando à sua vítima a possibilidade de defesa e revide - vontade que persistia muito tempo depois e que, de certa maneira, foi atuada quando narrou o episódio diante de um grupo que sabidamente execraria sua conduta.

Venho deixando grifada a expressão prática da crueldade, porque quero marcar a idéia de lidar com os atos cruéis praticados por estes indivíduos sem atribuir a eles o traço da crueldade, posto que uma tal atribuição faria esboroar minha questão. Obviamente pode-se perguntar em que condições torna-se possível que um sujeito cruel pratique uma crueldade, mas isto já não seria mais a mesma coisa. Quando nos deparamos com o relato de uma crueldade, é comum perguntarmos: como é possível que um ser humano tenha podido fazer isto? Esta é, em suma, minha questão; é a questão emocionada de alguém que testemunhou seres humanos praticando crueldades.

Quando fazemos este gênero de perguntas, as aulas de psicologia conduzem aos estudos sobre crimes e criminosos. Neste campo, algumas respostas são clássicas. As teses mais consagradas tratam de somar fatores biológicos, como anomalias cromossômicas e distúrbios neurológicos, com fatores mesológicos, como desestruturação familiar e modelos sociais 
agressivos. Uma vertente variante aponta a importância crucial de desvios no desenvolvimento emocional, especialmente no estabelecimento de relações objetais adequadas. De maneira geral, todas estas respostas confluem para uma classificação dos criminosos que subscreve os autores de crimes cruéis na rubrica das personalidades psicopáticas, particularmente entre os psicopatas desalmados e os explosivos, na nomenclatura proposta por Kurt Schneider em 1923. Isto permanece verdadeiro mesmo quando esta nomenclatura é explicitamente contestada: em essência, todos os teóricos do comportamento criminoso aceitam que a crueldade patente em alguns crimes decorre da incapacidade de seu autor para adquirir os valores morais da sociedade na qual estão inseridos, para perceber empaticamente o sofrimento de suas vítimas e para sentir remorsos pelas violências praticadas - em poucas palavras, incapacidade para experimentar psiquicamente o conflito entre sua conduta e as normas de convivência humana. $\mathrm{O}$ que de fato distingue as várias teorias existentes é o peso que atribuem aos fatores biológicos, ambientais e psicológicos envolvidos na determinação destas incapacidades.

Percorri cada uma destas explicações, mas nenhuma respondia inteiramente minha questão, pois todas partem de considerar o criminoso como portador de algo errado, ou como deficiente de algo certo, como se residisse neles a presença do mal ou a ausência do bem. Eu, entretanto, só encontrei na vida, entre aqueles infratores e seus familiares e entre as pessoas que conheci antes e depois daquele tempo, pessoas habitadas pelo conflito; os casos de Quincas e de Fulano o ilustram. 
Mas ambos os casos, nos respectivos momentos em que se tornou aparente a experiência do conflito - a palavra mère rebordada na carta de Quincas e a confissão emocionada de Fulano - traziam algo de especial: em ambas as situações havia desnudamento e cumplicidade entre as pessoas envolvidas. Não estou certa de haver encontrado as melhores palavras; talvez eu pudesse recorrer a algumas expressões já consagradas pela clínica psicológica, mas não seria verdadeiro fazer isto. Naquelas ocasiões, eu não era ainda psicóloga. Ainda não aprendera a fazer do reconhecimento dos meus limites e da aceitação do outro em seus limites a ferramenta de minhas relações. Eu apenas vivia nestes limites, como aquelas pessoas, porque não se pode fazer de outro modo. Assim é que a chegada inopinada de Quincas sujo e aterrorizado desnudava-nos a ambos nos limites de seu orgulho sangrado pelos vermes, de sua auto-imagem enlameada pelos excrementos, de meu nojo, de meu medo da polícia, de minha compaixão pelo seu aviltamento, de minha possibilidade de superar o nojo e o medo porque com-padecia de seus sofrimentos, porque era vulnerável também às desditas de meu orgulho e de minha auto-imagem. Isto tornava-me cúmplice de Quincas, e o acoitamento que eu the dava exauria esta cumplicidade. Doravante, e enquanto durasse esta cumplicidade, Quincas poderia confessar-me tudo quanto nela coubesse, inclusive seus remorsos. No caso de Fulano, aquela conversa havia sido precedida de um processo mais longo de desnudamento recíproco, que envolvia todas as pessoas presentes à sua confissão e que propiciava $\mathrm{o}$ clima de cumplicidade que a permitiu; seria extenso, e redundante, o relato deste desnudamento prévio, por isto não o faço. $O$ que me parece necessário assinalar é o quanto aquele clima de cumplicidade pode propiciar de sustentação para os sentimentos ambivalentes que Fulano, eu e os demais, nós todos, experimentamos. Naquela situação, ninguém pôde atuar senão o conflito; ninguém pôde reduzir qualquer outro à sede do bem 
ou do mal: a confissão de Fulano, nos termos em que se fez, impedia isto. É verdade que Fulano lançou mão de um mecanismo primário de defesa, procurando depreciar sua vítima como modo de reduzir a dissonância psíquica provocada por sua conduta; mas ele próprio não sustentava isto, e afirmava o tempo todo a vontade de encerrar a crueldade, dando chance de defesa ao rapaz. Porque confessou simultaneamente seu mal e seu bem, Fulano permitiu-nos acumpliciar-nos dele; Fulano lembrou-nos nossos pecados voluntários, nossos deslizes conscientes, nossas humanas contradições. A empatia tornou-se possível entre nós.

Penso ter dito o bastante para sustentar a afirmação de que, segundo minha experiência, a manifestação do conflito experimentado pelo sujeito está condicionada pela relação estabelecida entre ele e as outras pessoas. Faltaria afirmar que a qualidade desta relação, por sua vez, está condicionada pela possibilidade do outro em acumpliciar-se emocionalmente com o sujeito; possibilidade cambiante, sensível a múltiplos fatores. Hoje, apenas posso ilustrar o que estou afirmando; não posso explaná-lo melhor. Tomarei para tanto uma outra situação, ocorrida na mesma época, na qual mostrei-me incapaz de acumpliciar-me de um menino de 13 anos, Inha. Entre nós, não houve genuíno desnudar-se pois, embora nossos limites tenham se apresentado na relação, como é obrigatório, nenhum de nós podia reconhecê-los naquele momento, logo, nenhum de nós pôde aceitar verdadeiramente o outro.

Inha foi para a minha casa porque a mãe tentou interná-lo na Febem, denunciando sua participação no tráfico de drogas, também por causa de uma briga doméstica. Diante da assertividade com que Inha 
reagira às suas reprimendas e da ineficácia das punições físicas, a mãe entendeu que seus recursos educativos para afastar o menino da criminalidade haviam se esgotado, e acreditava que a Febem pudesse corrigi-lo. Ele não precisou esconder-se, apenas residiu em minha casa por cerca de dois meses, a poucos quarteirões da casa de sua mãe. Depois, acalmados os ânimos, voltou para sua família. Como pudesse circular pelas ruas, Inha continuava vendendo maconha. Como Quincas, mostrava-se tímido em minha casa, falava pouco e baixo. Se solicitado, executava prontamente qualquer tarefa mas nunca tomava a iniciativa de contribuir com os cuidados da casa. Nos primeiros dias, ofereceu-me dinheiro para as despesas domésticas e, como recusei, de outra vez trouxe-me bifes. É difícil contar isto, mas lá vai: fiz-lhe então uma preleção gentilíssima, muito bem intencionada, mas inteiramente desastrada, dizendo que quando ele arranjasse emprego (obtivesse dinheiro mediante uma atividade lícita), sua contribuição para a manutenção da casa poderia ser aceita; que sua permanência em minha casa não estava condicionada ao abandono do tráfico e ao retorno à escola, que ele abandonara nos primeiros anos, mas que isto seria preferível; e que eu, como os demais monitores do trabalho, o apoiaríamos nesta direção, se ele quisesse. Inha não abandonou o tráfico, não retornou à escola nem arranjou emprego - o que aliás seria muito difícil para um garoto de 13 anos, semi-analfabeto, de aparência malcuidada e linguajar grosseiro, que jamais saíra daquele bairro. O que ele fez foi passar a recusar alimentos em minha casa. Fazia isto também com muita gentileza: dizia sempre estar sem fome. Nunca contestou o que eu dizia. Também nunca aceitou meus conselhos nem seguiu minhas exortações; aparentemente, não podia assimilar qualquer coisa que eu lhe transmitisse, embora fosse cordata e atencioso comigo. Jamais confessou-me seus sentimentos. Às vezes, passando em frente ao bar onde funcionava a boca de fumo, eu o via comendo paçoquinhas de amendoim ou tabletes de doce 
de abóbora, que era tudo o que se vendia alí, além de cachaça e maconha. Hoje, penso que Inha pediu-me abrigo, a mim e não a outro dos monitores ou a um dos infratores, em parte porque eu já abrigara Quincas, mas principalmente porque eu era mais igual a ele, e à sua família, do que os outros monitores, além de ser suficientemente diferente dele, e dos outros infratores, para que ele acreditasse poder encontrar em minha casa maior compreensão e melhores condições para redirecionar sua vida. Minha preleção desastrada exagerou as diferenças entre nós dois, exatamente quando as pretendia negar. Aquele menino sentia suas limitações mais do que eu podia saber, das suas e das minhas; mais do que eu podia saber, porque sentir, eu as sentia inteiramente. Ele não intentaria um projeto para o qual faltavam-lhe os recursos mínimos até para a primeira etapa. Com o tempo, arrefeceu o empenho da mãe em desviar do crime seus filhos - Inha não foi o único deles que seguiu por esta senda. Com o tempo, também, Inha tornou-se mais poderoso e mais perigoso. Passou a ser conhecido e perseguido pela polícia, como Quincas. Diferentemente deste, porém, Inha tornou-se respeitado e admirado entre seus pares, pelo menos enquanto tive notícias dele.

Retomando agora minhas afirmações de há pouco, posso dizer que lá pelo quarto ano da graduação em psicologia eu delas concluía que devia ser na relação de um criminoso cruel com seus sócios culturais que se engendrava a idéia da psicopatia, conforme se apresenta na literatura. Imaginava mais: que esta idéia, circulando no meio social, devia engendrar as condições subjetivas nas quais tornava-se possível a um ser humano a prática da crueldade. Tratar-se-ia evidentemente de uma dialética. Tratarse-ia do engendramento social de um ser mítico, um homem monstruoso. Para mim, as forças de sua criação brotariam da impossibilidade cultural de 
suportar a angústia despertada pela ambigüidade, de sustentar a ambivalência. Inclinamo-nos a depurar nossos sentimentos, e diante de qualquer criminoso, violento ou não, sentimo-nos compelidos a desprezar nossos sutis estremecimentos de piedade, de simpatia, de com-paixão. Inclinamo-nos a depurar nossa apercepção das demonstrações dadas pelo criminoso, e nos deixamos afetar bastante por suas demonstrações de crueldade, insensibilidade, frieza; e quase nada, em contrapartida, por suas demonstrações de piedade, sensibilidade, afetividade. Pouco mais, e teremos pintado um diabo bem mais feio do que é. Pouco mais um tanto, e teremos criado um modelo de conduta para criminosos, que muitos deles adotarão diante das pessoas de bem. A psicopatia é um nome para este modelo.

Entremos agora na história deste estudo. Foi pelos comentários de Peter e Favret ao caso de Pierre Riviére, jovem que matou a mãe, a irmã e o irmão em 1835, e pela metáfora sublinhada por Junito Brandão na lenda do Minotauro, que comecei a organizar a idéia de uma construção social do crime monstruoso.

J. P. Peter e Jeanne Favret [Peter e Favret, 1977] fazem notar que o ato parricida de Pierre Riviére teve lugar em meio a uma onda de crimes assustadores, nas primeiras décadas do século XIX. Reconhecem nestas "belas monstruosidades" o caráter de um discurso emergente do campesinato, que o criminoso profere com seu ato, cuja forma pode ter sido forjada pela violência das carnificinas que se seguiram à Revolução de 1789. Dizem estes autores: "Suas ações são discursos, mas o que dizem eles, e por que falam esta língua assustadora do crime?". As respostas, para 
o caso de Pierre Riviére e dos "ogros e ogras" daquela época, encontramnas nas condições sócio-políticas que oprimiam o campo francês no advento do liberalismo. A exegese destes discursos, cifrados no parricídio, no filicídio e no canibalismo, fazem-na pela frase: "fixem na verdade, e não no engodo, um limite da natureza humana no qual possamos nos reconhecer. E eu cessarei de espantá-los com estas máscaras monstruosas". Mas a "máscara monstruosa" dos crimes cruéis continua a espantar a humanidade, ainda hoje, e ainda exige compreensão...

Relembremos agora a lenda do Minotauro: Zeus, assumindo a forma de um belo touro, seduziu a jovem Europa por quem se apaixonara. Tornaram-se amantes e, sob o céu de Creta, geraram três filhos: Minos, Sarpedon e Radamante. Minos tornou-se rei de Creta e desposou Pasífae. Dominada pela incontrolável paixão que lhe despertou certo touro, Pasífae recorreu a Dédalus, espetacular artesão e arquiteto. Este construiu em ouro o simulacro de uma novilha, sob o qual Pasífae logrou ser fecundada pelo touro. Desta união, nasceu um ser monstruoso, metade homem, metade animal. Minos chamou-o Minotauro, e ordenou a Dédalus que construísse um labirinto onde encerrá-lo por toda a vida. Junito Brandão assinala que o monstro representa (re-apresenta) uma faceta remota e essencial de Minos, negada entretanto na existência do rei [Brandão, 1995]. Minos, um homem, originou-se da união de um touro e uma mulher. O monstro vem apresentar-lhe sua porção taurina, daí o nome Minotauro, o touro de Minos. Daí também a necessidade de encerrá-lo no labirinto, símbolo do inconsciente, de onde nem o monstro nem pessoa que o avistasse poderia sair. Daí, ainda, a necessidade de preservar e alimentar o monstro - o que é feito com carne humana jovem, requisitada à Atenas como tributo de guerra. Teseu, príncipe ateniense, conseguirá finalmente abater $\mathrm{o}$ 
Minotauro. Ariadne, filha de Minos, deu-lhe um novelo com o qual marcará o caminho percorrido no labirinto, e saberá conquistar a saída.

Quando iniciei este estudo, há cerca de cinco anos (isto foi antes de iniciar o mestrado), parecia-me ter nas mãos o fio de Ariadne. Pensava: o aspecto monstruoso de alguns crimes deve revelar uma verdade intolerável aos homens; é isto que nos leva a encerrar tais crimes num labirinto de perplexidade e repugnância; é isto que nos impede a compreensão de seu sentido, que nos obsta a empatia para com seus autores, que nos obriga a negar seus traços de humanidade. Pensava mais: devemos conhecer, porém, esta verdade; caso contrário, a notícia de crimes bárbaros tornar-se-ia intolerável, e há muito teríamos cerceado sua veiculação. Em vez disto, alguns crimes monstruosos ganham celebridade na mídia, e não é raro serem imortalizados na literatura e no cinema. Mais que isto, cultuamos, ou consentimos em que muitas pessoas dediquem-se a cultuar, publicamente os autores de crimes cuja atrocidade estarreceram a humanidade. Ainda hoje penso que este culto, praticado ou consentido em nossa civilização, acusa-nos, não tanto ou nada de cumplicidade nos instintos ou desejos cruéis do criminoso, mas de certo remorso por fingirmos ignorar o sentido e o significado de seus atos, com o que convertemos estes criminosos em monstros destituídos dos sentimentos e códigos propriamente humanos. Ainda penso que tal culto não louva suas ações, não expressa admiração ou cumplicidade; apenas busca apaziguar em todos, criminosos ou não, o sentimento de uma atrocidade sem culpado. Então, pensei estudar um caso de crime, destes que parecem despertar a perplexidade e repugnância de todos; acreditava que, se o tomasse como um discurso, encontraria o sentido humano que revelava. Escolhi um caso: um quíntuplo homicídio ocorrido em meio a uma família... o estudo de um 
único caso, porém, resultou na imposição de que minha análise esteja restrita à sua singular concretude.

Sinto haver perdido o fio... mais adiante tentarei retomá-lo. Por ora, passo à minha dissertação de mestrado. Devo embrenhar-me na consideração específica dos crimes em família, e da família, portanto. Devo embrenhar-me na consideração específica das reações sociais ao autor dos homicídios em questão. Mas não poderia omitir os antecedentes deste estudo, sua história e sua pré-história, que em verdade muito condicionam seus limites e traçam seus contornos. 


\section{Capítulo 1:}

O trabalho de teorizar sobre homicídios 


\section{In t r o d u çã o}

Em junho de 1835, numa pequena aldeia francesa, Pierre Rivière, um jovem camponês, degolou sua mãe, sua irmã e seu irmão. Preso, escreveu um memorial pelo qual pretendia tornar conhecidos os motivos que o levaram a cometer tal crime. Condenado ao suplício dos parricidas, teve a pena comutada para prisão perpétua, em razão das dúvidas acerca de seu estado mental. Enforcou-se na prisão, em outubro de 1840.

Em janeiro de 1985, na periferia de São Paulo, Roberto, um jovem estudante desempregado, matou sua mãe, seu pai, sua irmã e seus dois irmãos. Preso, escreveram-se milhares de páginas, as quais pretendiam tornar inteligível os motivos que o levaram a cometer tal crime. Condenado a 25 anos de reclusão, teve a pena substituída por internação em manicômio judiciário pelo prazo mínimo de 3 anos, em razão do laudo psiquiátrico que atestava seu estado mental fronteiriço entre a normalidade e a loucura. Encontra-se internado até hoje, maio de 2001.

Entre ambos os casos, desdobram-se diferenças e semelhanças. Não as seguiremos, todas. Apresentei-os juntos para assinalar que a matança de uma família por um de seus filhos não é inusitada, nem indício do final dos tempos. Também para introduzir a idéia de que estaremos tratando de um modelo familiar específico - a família burguesa característico da modernidade. 
No primeiro caso, figuram como protagonistas a tríade formada por Pierre Rivière, seu pai e sua mãe. Segundo seu memorial, Pierre Rivère degolou sua mãe para por fim às aflições sofridas por seu pai, homem trabalhador constantemente enganado e desafiado pela mulher interesseira que o desprezava. A morte da irmã e do irmão prendiam-se a este mesmo propósito.

Será útil retomar a compreensão de Peter e Favret sobre o caso de Pierre Rivière, embora isto não substitua sua leitura direta. Tomado como um discurso emergente do campesinato francês, este crime pode ser interpretado por estes autores como um drama que colocou em cena os conflitos sociais daquele tempo e lugar. Peter e Favret assinalam no crime de Pierre Rivière o caráter de uma revolta contra a hipocrisia do liberalismo nascente, contra o quanto de tirania persistia aí, camuflada sob o regime dos contratos. Na dramática cena dos assassinatos, o pai representaria o povo trabalhador, ludibriado pela crença na igualdade entre pessoas desiguais, enganado pela idéia de uma liberdade vazia, sem recursos para ser exercida. A mãe representaria a tirania dissimulada, a rompedora dos contratos, nos quais a ordem da nova sociedade liberal dispôs seus elementos de controle (...) para aí ter em mãos e aí perpetuar hierarquias e desigualdades, mas desta vez e na hipocrisia, "livremente" consentidas [Obra citada, pág. 192]. Assim, Pierre Rivière se apresenta como aquele que levanta a questão do direito e do torto, do justo e do injusto, é aquele que, matando, poderá dizer a verdade e, monstro, deixar transparecer em seus dias monstruosos a regra de mentira e a máquina imunda ao sabor da 
qual seus semelhantes, os danados da terra, são e foram triturados, a cada dia, a cada vida [pág. 189].

O texto deste drama aparece cifrado no estilo das belas carnificinas que marcaram a derrubada do Antigo Regime, inaugurando a ordem liberal: a violência, Pierre Rivière e seus irmãos em assassinato, ogros e ogras de aldeia, mulheres frágeis cortando cabeças de crianças, não inventaram-na sozinhos. Nem este parricida, sedento de glória, a idéia dos holocaustos que lhe convinha realizar para o bem [pág. 195]; acontece que todos estes assassinos haviam sido instruídos, pela história recente, no gosto pelo sangue e, também, a matar e morrer para que na imobilidade imortal, alguma coisa ocorra, se ponha a viver, a mexer, a questionar, a alterar (...) o assassinato visa aqui, num mundo estático, ao intemporal da opressão e à ordem do poder [pág. 197]. Também visa tornar audível aos detentores do poder a pergunta: diga-nos então a natureza confessável por vocês daqueles com quem vocês aceitam contratar, mas de igual para igual. Quer dizer: fixem na verdade, e não no engodo, um limite da natureza humana no qual possamos nos reconhecer [pág.200].

Mas justiça e medicina logo fazem desaparecer numa névoa de palavras a pergunta que lhes é trazida [pág.200]. Isto porque, dominados, estes assassinos apenas matam seus irmãos de servidão. Dominados exemplares (...) não pensam em matar aqueles que contra eles asseguram o poder da lei - da mentira. É apenas nas pessoas próximas, nas pessoas familiares, no seio da família, que aquele que está alienado do jogo social pode reconhecer a dominação e atacá-la, redobrando os golpes: de uma vez matar vários, matar várias vezes. No caso de Pierre Rivière, é isto mesmo 
que permite aos juízes e médicos deixarem de reconhecer nele um camponês perdedor, que acredita instaurar uma nova era cortando a cabeça de um tirano (...) que aquela que torna os contratos irrisórios seja aqui a mãe, e não o soberano, isto permite à medicina reduzir o assassinato à sua dimensão sintomática, e o assassino à abstração de um caso clínico [pág.202]. Redução à loucura, contestável, incipiente, mas suficiente para limitar o alcance do ato de Pierre Rivière; sequer será morto como parricida: fazendo-o indultar, recusavam-se a ouvi-lo; declaravam, em suma, que a palavra nativa (camponesa) não tem peso (...) o ressentimento que pregam não tem razão de ser, é um produto de sua imaginação [pág. 208].

Também Roberto redobrou seus golpes contra seus familiares. Seria também possível ler seu crime como transcrição privada de um drama social? Seria precoce intentá-lo, nós, seus contemporâneos? Quem o faria?

Pois pareceu-me não apenas possível como necessário intentar esta leitura, e ainda mais produtiva quanto seja realizada agora, na contemporaneidade do caso - neste nosso momento, quando o noticiário assombra-nos com monstruosidades quase diárias, tal tarefa reveste-se de evidente importância. Claro que afirmar isto equivale a uma profissão de fé: penso que, se pudermos compreender as relações sociais - e nisto estão incluídas as relações familiares, as relações entre justiça, psiquiatria, imprensa, etc. - patenteadas pelo caso de Roberto em sua atualidade, então poderemos assumir uma postura política nessas relações, contribuindo para reproduzi-las ou para transformá-las. 
Mas há uma diferença importante entre os dois casos: Pierre Rivière escreveu, na solidão de sua cela, seu memorial. É este documento que virá a servir para Michel Foucault e seus colaboradores como ponto zero para medir a distância entre os outros discursos e as relações que entre eles se estabeleciam [conforme a Apresentação do livro, pág. XIV], permitindo a genealogia que caracteriza as notas acrescentadas ao final do dossier, inclusive a leitura proposta por Peter e Favret. Esta leitura trata de correlacionar símbolos, reconhecer papéis, identificar equivalências entre a história da sociedade e a história familiar, tudo isto com o ânimo próprio do projeto genealógico: compreender, naquele contexto, como as falas e os atos de cada sujeito estavam condicionados pelas relações de poder que vinculavam as pessoas e as instituições entre si; em outras palavras, como cada eu podia (tinha poder para) relacionar-se com os outros. Além disto, há um lapso de quase um século e meio de história iluminando o olhar destes autores. Resultado importante da análise que efetuam é a constatação da impossibilidade reservada a Pierre Rivière e seus conterrâneos para a fala e o ato transformador. Aos camponeses, apenas o trabalho e o falar cotidiano que sanciona o discurso dos notáveis, os donos do poder e das palavras; jamais o ato transformador, jamais a fala emancipadora. Pierre Rivière ousou ambas as coisas, da maneira como era possível a ele em sua condição: para ser ouvido, era preciso matar e aceitar morrer; feito isto, ele ainda legou sua palavra, o que tinha a dizer, em seu memorial.

Não recebemos, porém, igual legado de Roberto. Temos o registro dos depoimentos prestados durante o Inquérito Policial e o Processo Penal, mas estas falas foram colhidas por escrivãos e 
mediatizadas pela interpretação da autoridade policial ou judiciária que presidia a tomada dos depoimentos. Suas declarações publicadas pela imprensa escrita guardam a interpretação e a edição impostas sobre sua fala pelo repórter. Da mesma maneira, a confissão e a narrativa do crime feita por Roberto ao psiquiatra forense designado para examinar sua sanidade mental, aparecem registradas nos autos modificadas pelo perito, conforme ele explica: para melhor ilustrar a narrativa do réu, irão os peritos trazê-la à Justiça como se fosse um diálogo, semelhante ao que ocorrera naquela sala de entrevistas; ou seja, não se trata evidentemente do registro direto do diálogo que efetivamente ocorreu naquela sala. Há apenas um registro direto do discurso de Roberto, na transcrição de uma fita magnética na qual foi gravada uma de suas entrevistas; não é porém um discurso espontâneo, como o de Pierre Rivière em seu memorial, pois durante a entrevista Roberto apenas respondia às perguntas do repórter. Uma carta dele juntada ao processo penal dois anos depois do seu julgamento informa-nos que estava escrevendo, no manicômio, uma auto-biografia. Pedia ao juiz corregedor dos presídios do estado a cópia integral das ocorrências e depoimentos havidas durante o júri popular; aparentemente, seu pedido perdeu-se entre os trâmites burocráticos da Justiça. Na última entrevista dele ao jornal Folha de São Paulo, passados mais dois anos, Roberto diz que escreveu um livro de memórias, com 340 páginas manuscritas; este livro, até onde pude averigüar, não foi publicado.

$\mathrm{Na}$ falta do discurso de Roberto sobre si mesmo e sobre seu crime, ainda seria possível efetuar a genealogia dos discursos referentes ao seu caso? Ou seja, como se poderia medir as distâncias entre os diferentes discursos registrados sobre Roberto e seus crimes, de modo a desvelar, ainda na atualidade dos acontecimentos, as relações de poder entre as 
pessoas e as instituições que enunciaram estes discursos? Parece-me que um dos modos é inferir esta distância da medida entre o que está e o que não está dito sobre o caso. Estou sugerindo, então, um passo da arqueologia à genealogia.

A referência ao livro Morte em Família, de Mariza Corrêa [Corrêa, 1983], pode ajudar a esclarecer o sentido desta minha sugestão. Em verdade, o planejamento e a execução do estudo sobre o caso de Roberto precedeu minha leitura do trabalho de Mariza Corrêa. Entretanto, encontrei em seu livro boas justificativas para parte do que eu já havia feito e, por isto, valho-me delas para sustentar a estratégia que adotei na investigação, ou antes, o primeiro passo de minha análise.

\section{O trabalho arqueológico de descobrir fábulas}

“Claro, por último existem sempre três versões: a sua, a minha e a verdadeira ${ }^{1}$,

Mariza Corrêa analisou 48 processos penais relativos a homicídios e tentativas de homicídio entre casais e levados a julgamento pelo tribunal do júri da cidade de Campinas, São Paulo. Segundo a própria

\footnotetext{
${ }^{1}$ Frase de um promotor, citada por Mariza Corrêa [pág. 41], para enfatizar que os atores jurídicos têm plena consciência da manipulação que realizam todo o tempo durante o processo.
} 
autora, ela buscava compreender de que elementos se compõem as idéias sobre a mulher em nossa sociedade, e os processos jurídicos de homicídio entre homens e mulheres pareceu-lhe o material ideal para o estudo daqueles elementos, porque não só apanharia a discussão de casos onde os direitos e deveres de cada um em relação ao outro seriam necessariamente confrontados, como também uma decisão social a eles atribuída, uma vez que no Brasil os casos de homicídio (...) são julgados pelo tribunal do júri [Obra citada, págs. 21/22]. Ela reforça os fundamentos de sua estratégia, ainda, pela afirmação de que um momento de crise extrema da união entre um homem e uma mulher, a eliminação de uma parte dessa sociedade pela outra, pode ajudar a pôr a nu os pressupostos de sua existência, a identidade social atribuída a homens e mulheres em nossa sociedade enquanto figuras complementares de uma unidade básica, a família [pág. 23].

Mas, ao aproximar-se do seu material de estudo - os processos penais - a autora percebe estar deixando o campo da realidade factual, e adentrando o campo do simbólico. Dá-se conta, conforme suas palavras que secundo, de estar lidando o tempo inteiro com metáforas, com símbolos e sua utilização. A morte de uma pessoa pela outra é imediatamente despojada de seu peso concreto, espesso, da espessura que possui em sua esfera de ação, e transformada numa parábola, numa fábula, onde estão contidas todas as mortes possíveis de acontecer neste mundo para o qual se volta a visão jurídica, uma visão que ordena a realidade de acordo com normas legais (escritas) preestabelecidas, mas também de acordo com normas sociais (não escritas), que serão debatidas perante o grupo julgador [pág. 24]. Esta compreensão leva a autora a efetuar duas leituras dos processos: Na primeira tento mostrar como a construção da fábula 
obedece a um plano já traçado, um plano assim mesmo flexível e a utilização dessa possibilidade de acomodação pelos atores jurídicos e, na segunda, quais os elementos de que a fábula é construída, que fábula masculina e que fábula feminina são aceitas em nossa sociedade [pág. 27].

Desta análise, a autora extrai conclusões relevantes para a compreensão das definições aceitas pela sociedade brasileira para os papéis feminino e masculino e para a instituição conjugal e, mais importante para o tema que ora temos em pauta, do modo como estas definições são sancionadas pelo sistema jurídico. Ainda mais uma vez, embora seja um longo trecho, será melhor ler a própria autora:

Quisemos mostrar que os procedimentos de constituição, de construção de um caso levam à instauração de uma espécie de verdade que se expressará afinal no resultado do julgamento. Mas esta 'verdade' constrói-se não apenas por analogia com as situações reais, vividas pelos que sofrem o processo, ou com os códigos onde elas deveriam estar previstas - mas também de acordo com os "modelos admitidos"(Chaim Perelman, "Le Champ de l'Argumentation", Presses Universitaires de Bruxelles, 1970, pp. 62) nesta sociedade. Quando um caso está sendo construído, ele está ao mesmo tempo constituindo seu próprio código, delineando seus próprios limites, escolhendo o que não será, o que não pode ser dito ao mesmo tempo que o que pode e deve ser dito (...) tendo decidido como enquadrar legalmente um caso, os manipuladores técnicos utilizam o tempo do processo selecionando e ajustando os elementos 
das situações, as 'peças' do processo, que mais se adequem à composição da figura desejada, da verdade a ser demonstrada.(...) As situações que acontecem no mundo, fora dos autos, são espessas e ambígüas, possuem mais de um significado e delas se permitem várias interpretações. As relações que aí se estabelecem são determinadas pelas condições de vida a que estão sujeitas as pessoas que as põem em prática. Essa diversidade e ambiguidade são negadas no momento em que os fatos e relações passam pelo crivo de uma linguagem formalizada que transforma a possibilidade de interpretações múltiplas, reduzindo-as à possibilidade de apenas duas interpretações, ambas tributárias do mesmo modelo [refere-se às teses de acusação e defesa]. No processo é produzida uma mediação que achata a espessura inicial dos acontecimentos e despolitiza as relações entre as pessoas no mundo, ao ignorar o seu contexto básico (...) As duas interpretações possíveis serão ainda uma vez reduzidas na decisão que será, além da escolha da apresentação mais coerente com o modelo que os julgadores visualizam para a sociedade onde vivem, também um selo de aprovação dos procedimentos escolhidos por essa mesma sociedade na transformação mencionada [pág. 300/301. Grifei.].

A análise das fábulas judiciais construídas durante os processos penais dos homicídios cometidos no âmbito conjugal conduziu Mariza Corrêa a localizar nas relações de poder admitidas na sociedade as condições de sustentação tanto das conflitivas relações conjugais que resultaram nos homicídios, quanto do modo como o poder judiciário 
formula sua resposta aos crimes: No momento em que a morte de uma pessoa pela outra é apresentada como o resultado de uma luta de forças internas, intimas, domésticas, que podem ser quase reproduzidas no processo e no julgamento (...) escondem-se, ao mesmo tempo que se as revelam, as tensões inerentes a essa relação doméstica, ao tomá-las como ecos de um jogo natural e a-histórico e como equivalentes e homogêneos os motivos que a desencadearam. Esconde-se também a luta mais ampla onde essa luta íntima está contida, a tensão a que estão submetidos os mais fracos nessa luta, os mais afastados do poder, a grande maioria das pessoas [pág. 308].

Mas o que tornou possível esta transição, da investigação daquilo que está dito ou não dito nos autos para o reencontro das relações de poder que fundamentaram a construção dos discursos? Segundo a autora, trata-se da estratégia adotada: procurar analisar muitos processos, não para abstrair deles o código ideal que regula suas constituições, mas para poder confrontar a construção singular de cada um deles com a construção de cada um dos demais. Esta confrontação permitiria perceber a repetição de símbolos que enquadram a figura da mulher e do homem na grade das regras sociais tácitas que ordenam suas relações, operando com maior força que a máxima legal explícita da igualdade. Mas a própria autora deixa entre as frases finais do livro uma advertência: Esta utilização reiterada de um aglomerado de signos que definem a identidade social de homens $e$ mulheres só faz sentido no entanto se tentarmos perceber os princípios mais gerais que regem não só a aplicação das leis mas também a vida em nossa sociedade [pág. 311]. Retomando a Introdução do livro, vê-se que desde então a autora deixou restar a questão de como se pode conhecer 
estes princípios, admitindo simplesmente que sua leitura dos autos esteve carregada do que sei [pág. 26].

O memorial de Pierre Rivière, mais 150 anos de história, serviram para iluminar a análise de Peter e Favret daquilo que sobre ele disseram em sua época. Penso que a análise de Mariza Corrêa sobre os 48 processos penais contemporâneos que estudou esteve, por sua vez, iluminada pelo que a pesquisadora sabia sobre as questões de gênero na sociedade burguesa.

Acreditando-se no trabalho de Mariza Corrêa, é perfeitamente aceitável tomar os autos do processo judicial do caso de Roberto como meio adequado para investigar os estereótipos aceitos na sociedade para os papéis familiares de pais, filhos e irmãos; também para investigar o modo jurídico de restaurar a validade destes estereótipos, abalada pelo crime. Nesta tarefa, a justiça receberá apoio da psiquiatria. O processo penal " $O$ Estado contra Roberto..." pode ser lido como a fábula juspsiquiátrica possível nas circunstâncias do crime - aquele crime particular, naquele particular momento da justiça e da psiquiatria, não poderia ser falado de outro modo. Estes limites podem ser revelados pelo contraste entre aquilo que é dito e aquilo que não é dito nos autos; trata-se, até este ponto, da análise arqueológica do discurso. Entretanto, o contraste - que naturalmente não é imediato - da fábula da família assim revelada com o sistema sócio-político contemporâneo adentra o nível de análise genealógica, ou seja, conduz às relações de poder que sustentam ambas as coisas. 


\title{
O trabalho genealógico de compreensão das fábulas
}

\author{
"Se se examina com rigor, a 'família burguesa' é algo que \\ não existe: nela, o pretenso princípio racional do individualismo \\ entra em contradição consigo mesmo $(. . .)^{2}$ "
}

Este percurso entre a arqueologia e a genealogia, na falta do memorial de Roberto e de 150 anos de história, precisa ser iluminado, necessariamente, por uma reflexão sobre as relações entre família e sociedade no sistema capitalista; e quero deixar explicitada ao menos uma das fontes onde busquei elementos para esta reflexão. Para tanto, pode valer a Introdução escrita por Massimo Canevacci para a coletânea de textos entitulada Dialética da Família. Gênese, estrutura e dinâmica de uma instituição repressiva, [Canevacci, 1981] especialmente porque beneficia a concisão sem prejudicar a profundidade necessária e suficiente para subsidiar a discussão que quero empreender.

O objetivo central que move a escrita de Canevacci, bem como a seleção dos textos que compõem a coletânea, é sugerir uma abordagem da família tardo-burguesa - a família nuclear, monogâmica e patriarcal - que propicie sua superação ${ }^{3}$. Entretanto, não será preciso acompanhar Canevacci por todo o trajeto que faz até chegar às conclusões sobre a

\footnotetext{
${ }^{2}$ Frase de Adorno e Horkheimer, discutindo a crise da família no tardo-capitalismo, em Sociologia da família; excerto publicado in: Canevacci, citado, págs. 213-222.

${ }^{3}$ Esta abordagem estaria caracterizada por uma atitude científica interdisciplinar, rompendo com o espírito de especialização que reflete e reproduz a divisão do trabalho; também por uma atitude política dialética, promotora da transformação das relações humanas na direção de
} 
estrutura e a dinâmica que garantem o cumprimento das funções da família na sociedade tardo-capitalista e às sugestões para sua transformação; para meu propósito, bastará recuperar em traços largos apenas três momentos deste percurso. Estes momentos referem-se aos vínculos da instituição familiar com o autoritarismo, ou seja, com a dominação do homem pelo homem; com a exploração, mais especificamente com a exploração capitalista; e com a reprodução das relações entre capital e trabalho.

Inicialmente, será preciso relembrar a consagrada tese de LéviStrauss, segundo a qual a tríade formada pelo fato natural da procriação - a família biológica: pai, mãe e filho - não constitui a base das relações familiares e sociais. A verdadeira estrutura elementar do parentesco fundase sobre o fato cultural da proibição do incesto, que institui laços sociais de reciprocidade entre os cunhados: a doação da irmã pelo irmão para esposa do cunhado faz deste obrigado a doar, por sua vez, suas próprias irmãs à outrem, estabelecendo assim uma rede de relações sociais. O átomo social seria, então, constituído pelo irmão da mãe, pai, mãe e filho; neste quarteto, os vínculos de afeto e de autoridade são distribuídos de maneira a formar dois pares de oposições: pai-filho, tio-sobrinho e marido-mulher, irmãoirmã. Canevacci sublinha duas conseqüências derivadas desta concepção: primeira, a afirmação da supremacia da afinidade como fundamento das relações de parentesco, contra a tese mais ou menos universalmente reconhecida da filiação, que conduz de fato à aceitação irracionalista de uma naturalidade objetiva e imperscrutável, fatalisticamente teleológica, e segunda, a afirmação de que a proibição do incesto é a regra de reciprocidade por excelência, e a exogamia é sua expressão socialmente

novas formas familiais contrárias à dominação, rompendo com as racionalizações legitimadoras mas também com as propostas idealistas (e inócuas) de destruição da família. 
ampliada (...). Com a invenção universal do tabu do incesto, a família assinala o momento da passagem da natureza à cultura [Obra citada, págs. 26-27].

Destas afirmações, Canevacci conclui que a família não é tanto um microssistema a ser relacionado com um macrossistema social (...) mas sim a estrutura que - mais do que qualquer outra - contém em si a esfera da cultura e a esfera da natureza. Numa perspectiva antropológica, a supremacia da primeira deverá afirmar a vitória do princípio da afinidade, da razão e, portanto, da solidariedade humana autoconsciente, contra o perigo de um retorno à naturalidade cega e ao direito absolutista de filiação. Esse último, na sociedade tardo-burguesa (...) transforma-se em puro irracionalismo, sem outro fim que não a própria autoconservação autoritária [pág. 29].

Será interessante seguir agora um trecho que aparece mais adiante em seu texto: $\mathrm{Na}$ adequação ao que é aparentemente natural (quando na realidade é cultural) e sancionado por uma tradição atávica, forma-se o complexo de Édipo, que encontra seu primeiro terreno na absoluta desproporção entre o poder do pai e a impotência do filho [pág. 34]. Depois, Canevacci ainda dirá que o complexo de Édipo deve ser visto como reflexo do terror de Laio, que tem sua origem na condenação histórico-natural que toda geração paterna experimenta em relação a si mesma, como conseqüência da pura e simples presença de um filho: a sucessão na vida, nos bens, no sexo (...) o complexo de Édipo é o produto do terror autoritário de Laio negado, invertido e projetado [pág. 36]. 
Será preciso recuperar, também, um outro ponto de apoio importante para as conclusões de Canevacci: o reconhecimento das relações históricas entre as formas familiares específicas e a propriedade privada, proposto inicialmente por Morgan e Engels. A contribuição pioneira destes autores ressaltou, basicamente, dois aspectos essenciais para compreender a instituição do modelo familiar monogâmico e patriarcal: primeiro, que esta não é a forma mais primitiva e natural da família, mas sim o resultado de um desenvolvimento histórico; segundo, que este modelo responde ao surgimento, também histórico, da idéia de propriedade privada e à conseqüente necessidade de regular sua transmissão.

As observações de Malinovski entre os trobriandenses - que ignoram a participação do sexo masculino na geração dos filhos, tidos como produto exclusivo da mulher - constatando as relações amistosas e desinteressadas entre pai e filho - cujo vínculo biológico não encontra qualquer reconhecimento social - em contraste com as relações hierárquicas e autoritárias entre tio materno e sobrinho, são interpretadas por Canevacci como testemunho de que a descoberta do nexo causal entre ato sexual e procriação, na medida em que permite estabelecer uma descendência certa e legítima, foi a viravolta histórica para a transmissão hereditária dos bens e, portanto, para a "invenção" da família monogâmica patrilinear. Com ela, afirma-se uma lei cíclica pela qual o pai tem, em face do filho, todos os direitos, a fim de que, quando da sua morte, 
o próprio filho lhe suceda, reinvindicando por sua vez os mesmos privilégios em face do seu descendente [pág. 34] $]^{4}$.

Finalmente, será preciso mencionar o reconhecimento da crise do modelo familiar burguês no capitalismo tardio, relacionado com o progressivo solapamento do poder paterno pela expansão do poder social e econômico. Como o próprio Canevacci, sobre isto, sugere a seus leitores recordar as conclusões da Escola de Frankfurt, será conveniente abandonar por um momento seu texto para resumir, da Sociologia da família de Adorno e Horkheimer, estas conclusões. Estes autores fazem notar que a crise da família pode ser compreendida como efeito do desdobramento do antagonismo fundado no momento mesmo em que esta instituição - essencialmente feudal, fundada no principio do "sangue" e do parentesco natural - passa a operar como instância de adaptação à sociedade moderna - orientada ao contrário para ordenações racionalistas. Claro que, do ponto de vista dialético, precisamente este anacronismo permitiu à família desempenhar tal função; só a autoridade irracional que tomava corpo na família foi capaz, no curso do tempo, de levar os homens a realizar os esforços indispensáveis para reproduzir, nas condições de assalariados separados da propriedade dos meios de produção, a sua força de trabalho e, com isso, a sua vida.[In: Canevacci, obra citada, pág. 215]. A submissão ao poder paterno, a idealização deste poder, sua internalização como instância moral do indivíduo, numa palavra, o desfecho normal do Édipo freudiano, isto estabelecia o substrato inconsciente sobre o qual as relações irracionais do sujeito com seu patrão capitalista podiam aparecer racionalizadas à sua consciência: (...) a criança

\footnotetext{
${ }^{4}$ Canevacci não esclarece a razão da necessidade da transmissão hereditária dos bens, ou seja, que motivo levaria a aceitar-se que o filho tenha, obrigatoriamente, que ser o herdeiro.
} 
- que forjava a partir da força paterna suas próprias instâncias morais e, portanto, sua consciência-para aprender finalmente a respeitar e amar o que se oferecia ao seu intelecto como efetivamente existente, aprendia também a relação burguesa com a autoridade, e não apenas no referente à esfera parcial da família (...) Na irracionalidade da família refletia-se assim a irracionalidade de uma sociedade na qual aparentemente tudo acontece segundo a razão, mas na qual domina a irracionalidade de relações cegas, subtraídas à liberdade da razão [Idem, pág. 217].

Mas o poder paterno, se é feito da assimetria da força bruta, também é feito de carinho, proteção e orientação; se o direito irracional da filiação dá razão sempre ao pai durante a vida, em sua morte recompensa o filho com a herança. Ora, estas sutilezas de reciprocidade não encontram guarida na lógica individualista e competitiva do capital. O desenvolvimento do capitalismo solapa inexoravelmente o poder da figura paterna, atingindo-o em ambas as bases: do ponto de vista econômico, a expansão monopolista tornou escassos os pais que podem garantir segurança material aos filhos, e mais ainda os que possuem bens hereditários suficientes para garantir a obediência; do ponto de vista afetivo, a crescente especialização do trabalho destituiu os pais de sua aura de sabedoria e independência - isto aliás atinge facilmente o grau da franca obsolescência da geração dos pais frente aos avanços da tecnologia restringindo sua função educativa e orientadora, cada vez mais açambarcada por instâncias sociais exteriores à família ${ }^{5}$. Da antiga

\footnotetext{
${ }^{5}$ Especificamente sobre este tópico, é ainda mais esclarecedora a análise efetuada por Alexander Mitscherlich no texto $A$ ausência do Pai [extraído de Mitscherlich, A. Verso una socitá senza padre. Milão, Feltrinelli, 1970], publicado em Canevacci, citado, às páginas 236243.
} 
autoridade paterna, não resta muito mais que o efêmero papel de repressores da sexualidade e, mesmo neste campo, com poder cada dia mais diminuído.

Esta é a análise que permite a Canevacci cunhar a expressão família-fetiche para referir-se à família tardo-burguesa. $\mathrm{O}$ autor não se ilude, porém, acreditando que este aparente estertor prenuncie a morte da família burguesa; não enquanto instituição reprodutora das relações sociais de domínio e exploração. Ao contrário, faz observar que a superação deste seu aspecto apenas será alcançada mediante a disseminação e estabilização de comportamentos familiares emancipados dos vínculos com o autoritarismo e com as contradições entre capital e trabalho assalariado. Para contribuir com este processo, propõe a intervenção teórica e prática de toda antropologia que se pretenda libertária sobre o tríptico família-escolafábrica, sublinhando as correspondências entre estas instâncias sociais: Pai-professor-patrão, diz ele, são símbolos agora gastos de direitos usurpados: o primeiro, da natural capacidade biológica de procriação e da transmissão hereditária dos bens; o segundo, do trabalho intelectual "dividido"; o terceiro, da apropriação privada da riqueza social produzida e do trabalho executivo dividido [pág. 46]. Lucidamente, Canevacci recusa ocupar-se da idealização de uma nova família da esquerda. Neste sentido, aponta apenas que o único caminho praticável, elevado à clareza do conceito e da consciência, será a necessidade de destruir o complexo de Laio e o cego autoritarismo das relações sociais tardo-burguesas... [pág. 50]. 
Para o presente estudo, estas considerações sobre a família tardoburguesa têm a mesma serventia da planta fundacional de um edifício, quando estamos perdidos em seus corredores: suas marcações não indicam o caminho a seguir, mas oferecem pontos de referência que podem servir para encontrar a saída. Conclusão obrigatória da leitura de Canevacci é que a família sustenta-se, na atualidade ${ }^{6}$, sobre apoios muito precários, que se desestabilizam mutuamente. No nível da estrutura sócio-econômica, sua função primordial - e seu principal apoio - parece ser a garantia da transmissão privilegiada do capital, sancionada pelo direito hereditário; nos meios urbanos, quase nada restou do seu caráter de agência socializadora, e mesmo este mínimo é disputado palmo a palmo pela puericultura, pedagogia e saberes psi. No nível ideológico, a preleção individualista e competitiva erode diuturnamente o senso originário do dever de solidariedade recíproca entre os familiares; em acréscimo, determina um ordenamento da vida cotidiana impeditivo das práticas de apoio mútuo, quando não obriga ao total distanciamento. Nestas condições, tornam-se bem frouxos os laços do parentesco, e disto a enxurrada de leis de proteção à família é um paradoxal testemunho - que outra coisa dizer, por exemplo, da recente tipificação do crime de abandono material do idoso?

Caso não seja sublinhada, é fácil perder de vista a enormidade do que se enuncia nesta conclusão. Ultrapassado o montante do amor natural entre pais e filhos, que elos se criam no interior de uma família? Pois bem, é preciso dizer que são os elos da acumulação, da concentração e da

\footnotetext{
${ }^{6}$ Canevacci chamou de família tardo-burguesa ao modelo nuclear, monogâmico e patrilinear típico dos países de capitalismo maduro. Creio, porém, que não pode haver controvérsia sobre aceitarmos este modelo como característico dos arranjos familiares da classe média paulistana nas últimas décadas (pelo menos em torno de 1985, data do crime em pauta), que é com que se ocupa este estudo. Para maior clareza, doravante direi família moderna para referir tal modelo, ou tão somente família.
} 
transmissão do capital. Nos limites deste trabalho, não seria possível extrair todas as conseqüências desta fórmula, aplicando-as às formas familiares concretas distribuídas ao longo das posições sócio-econômicas possíveis. Mas é evidente que não serão as mesmas para uma família burguesa, realmente detentora de capital, ou para uma família trabalhadora, inteiramente despojada de capital. Interessa particularmente a situação da chamada pequena burguesia, expressão em desuso mas que guarda a conveniência de resumir a situação ambígüa daquele que tem suficiente dinheiro para arremedar o burguês sem ter, entretanto, seu atributo essencial, o capital - pois aí, na família pequeno burguesa, estarão mais visíveis as condições que fazem da instituição familiar um verdadeiro dispositivo de absorção dos conflitos resultantes da ordem contraditória do capitalismo.

O imperativo de classe para o pequeno burguês, todos sabemos, é tornar-se burguês, é acumular capital. Não pode fazê-lo, porém, se não o tem; torna-se imperativo, então, obtê-lo através do trabalho, ou seja, do salário. Pela força do direito hereditário este imperativo visa a família pequeno burguesa; é preciso que nela se concentre dinheiro suficiente para converter-se em capital. Para isto, será preciso driblar a lógica do salário, orientada para a perpetuação das relações de classe. Lembremos que esta lógica assenta-se sobre dois cálculos: o valor social do trabalho, e o custo de reprodução da força de trabalho; esta lógica decalca-se automaticamente no cotidiano daqueles que devem administrar um salário. Em tese, o drible seria possível, então, por dois movimentos: valorizar o trabalho individual e poupar a parcela possível do salário equivalente à reprodução da força de trabalho.

A família é guardiã, já anedótica, da receita prática do primeiro movimento: estudar. Todos conhecemos a expressão bricalhona de quem 
reclama das próprias condições de trabalho dizendo: bem que minha mãe mandava eu estudar..., e conhecemos também a ansiedade despertada na família de classe média quando um filho vai mal na escola ou interrompe os estudos; ninguém estranha isto, mesmo quem não ignora que tal receita funciona na nossa sociedade como um ardil ideológico. É que a exortação ao estudo coaduna-se bem com a imagem da preparação do jovem para o futuro - imagem benigna, harmoniosa com a idéia da família como união amorosa que gera a vida.

Passa-se o contrário quanto à receita prática do segundo movimento necessário à concentração do dinheiro no âmbito familiar. Não há modo de enunciá-la senão pela exortação ao celibato. Ora, mas não há modo de enunciar uma tal exortação dentro da família sem incorrer em uma contradição notável, sem evidenciar a usurpação do direito de procriação que Canevacci sublinha; trata-se de uma exortação mortífera, sem dúvida. Contudo, a condição sócio-econômica da família pequeno burguesa torna imperativo fazê-la, e será feita. Logicamente a família não o fará na forma direta que, com o mesmo propósito, todos sabem, o fez a Igreja Católica Apostólica Romana quando instituiu a castidade e o celibato dos padres. $\mathrm{Na}$ família, esta exortação se faz ao preço de conflitos, subjetivos em primeiro $\operatorname{lugar}^{7}$, que a revestem dos disfarces típicos do desejo inconfessável. A família pequeno burguesa fala, de preferência, em um adiamento do casamento e da prole, para depois da acumulação suficiente; trata-se de uma tentativa de instaurar a temporalidade do desejo - adiar fala duas coisas: não será feito agora, será feito depois.

\footnotetext{
${ }^{7}$ As categorias "pai" e "filho" são posições relativas, não temporais. Laio, o pai, é também filho de Labdaco; Édipo, o filho, é pai de Etéocles, Polínices, Ismênia e Antígona. É preciso lembrar que somos inconscientemente habitados pelo desejo de pai e pelo desejo de filho, simultaneamente - desejo atemporal que engendra o conflito subjetivo manifestado diuturnamente em nossa vida cotidiana; isto vale para os pais e para os filhos reais.
} 
Isto, $\log$ o se vê, difere fundamentalmente do compromisso de pais e filhos no desfecho edípico freudiano - neste, há uma regra intransponível cuja obediência é condição da satisfação do desejo: não o fará com a mãe, mas com qualquer outra mulher. A regra pequeno burguesa que pretende adiar esta satisfação para depois da acumulação do capital suficiente, o pai pequeno burguês está desacreditado para abonar posto que ele é a prova viva da impossibilidade desta acumulação. A herança futura em favor da qual exorta seus filhos a renunciarem agora a seus desejos de pai, eles mesmos, os filhos, devem ajudar a construir. Fica pervertida, assim, a temporalidade cíclica que sustenta o direito hereditário em sua função de garantidor da obediência filial.

O enunciado desta exortação, mediante miríades de disfarces, deverá deslocar o acento de sobre as barreiras estruturais erguidas contra a realização da acumulação, colocando-o sobre os indivíduos que se defrontam com tais barreiras. Bem outro seria o destino do pequeno Édipo se Laio, em vez de um rei, fosse um trabalhador assalariado que não pudesse dispensar a colaboração do filho; não teria o pequeno sido aleijado no Citerão, mas em sua própria casa. É que seria preciso mantê-lo vivo e casto, e ainda convencê-lo da necessidade de ajudar seu pai a realizar sua tarefa - agora imperativa tarefa de Édipo. Em se tratando de uma tarefa impossível, mas que não se poderia revelar como tal, todas as dificuldades deveriam ser atribuídas tão somente a ele próprio; em vez de seu bordão, de outros instrumentos seria munido para enfrentar seu pai: da rivalidade, da depreciação e do escárnio. Estas as contradições que são objetivadas no chamado conflito de gerações.

Se confiamos nas análises apresentadas, é inevitável reconhecer que a família presta-se muito bem como véu para ocultar as contradições do sistema capitalista, e como malha ideológica que sustenta a 
institucionalização do autoritarismo, ou seja, das relações de poder que subjugam o homem. Não admira que as celebrações santificadoras da instituição familiar dificilmente deixem de apresentar o sabor do exagero quase tão ruim quanto o das imagens publicitárias do ideal familiar moderno, temperadas com hipócrita manipulação: é que estas representações precisam despi-la momentaneamente do véu e da malha que compõem suas vestes habituais, com as quais a conhecemos no dia-a-dia. $\mathrm{Na}$ realidade, o efeito teatral desta operação aparece invertido: em vez de iludir o espectador, o figurino realça precisamente os aspectos que pretendeu disfarçar, e assim os revela. Todavia, revelar é desnudar, mas é também velar de novo. Para descrever a família, são enganosas tanto a imagem do amor altruísta, desinteressado e perene quanto a imagem do despotismo egoísta, insidioso e cruel. Quando nascemos e sobrevivemos humanos e modernos, experimentamos ambas as coisas, necessariamente; nisto reside o potencial dialético da família e sua importância histórica na formação das subjetividades - em última análise, na transformação das relações de alteridade.

Principalmente, não é possível falar do despotismo engendrado na família pequeno burguesa sem que o venha iluminar a compreensão da contradição fundamental entre suas preleções e a lógica da acumulação capitalista. Como discernir a função despótica dos conselhos paternos para o afinco nos estudos e para o adiamento do casamento até alcançar condições financeiras favoráveis, sem levantar questões relativas ao modelo sócio econômico vigente? Entretanto, o propalado conflito de gerações impõe sua presença ao discurso, e muito se haverá de falar sobre sua ocorrência; sob o interdito, porém, de tudo quanto toque precisamente o que este conflito vem esconder. O mais seguro é falar disto apenas 
genericamente, evitando o mais possível a consideração dos modos concretos como se articula e se apresenta em cada família real.

A leitura das páginas que registram a verdade juspsiquiátrica sobre o quíntuplo homicídio praticado por Roberto traz sabor de propaganda de shopping center no mês de maio: sabor de exagero, de maniqueísmo, de manipulação e de hipocrisia. É que o crime real aparece transfigurado como cerimônia de vilipêndio da família ideal, o avesso de sua santificação; a família morta, real, é abstraída; o homicida real é convertido num monstro fabuloso, num homem desumano. Parece-me plausível que a razão deste procedimento possa derivar da circunstância da família ideal figurar como justificativa para as contradições de um sistema sócio-econômico cuja força de dominação reside precisamente no fato de que à muda exploração engendrada pela propriedade privada dos meios de produção corresponde a eloqüente apologia da liberdade e da igualdade neste sistema, não se pode falar de formas mudas de domínio, exploração e revolta; deve-se, sim, louvar as formas bem falantes da resistência diálogo, democracia, opinião, contrato. Neste sistema, a violência muda de um homicídio, especialmente quando ocorrido no âmbito da família, deve ser falada com exagerada cautela para não incorrer no risco de denunciar a presença silenciosa da dominação.

Retificar as distorções operadas na realidade pela função política destes discursos excessivamente cautelosos é tarefa impossível. Contra os sedutores apelos da vontade de verdade, será preciso lembrar a advertência de Mariza Corrêa sobre os processos penais, que serve aqui perfeitamente: Estamos no nível do simbólico: este trabalho é uma leitura de discursos 
que expressam uma ordenação da realidade. A escolha da palavra fábula para designar essa ordenação enfatiza a idéia de que os fatos estão suspensos, de que não há mais a possibilidade de, através dos processos, revivê-los, fazer a caminhada inversa e chegar aos fatos reais, às relações concretas existentes por detrás de cada crime [Corrêa, obra citada, pág. 26].

A tarefa, então, será utilizar a luz desta compreensão para tão somente desentronizar destes discursos as fábulas gestadas no arranjo social e na cautela dominante. Ou seja, estou defendendo a necessidade de uma composição dos trabalhos arqueológico e genealógico como maneira, talvez única, de alcançar a descoberta e a compreensão dos condicionantes da fábula juspsiquiátrica escrita sobre o caso de Roberto. Precisamente porque sua construção responde, do lugar da sociedade, ao crime cometido por Roberto, no lugar do indivíduo, o reconhecimento desta fábula permite a leitura daqueles homicídios como transcrição privada de um drama social - como resposta muda de um indivíduo à uma situação social conflituosa e opressiva.

Embora seja um momento imprescindível de sua preparação, esta não é ainda a tarefa própria da psicologia social. Faltaria compreender que a transcrição privada de um drama social deve implicar processos de interação entre indivíduos e coletividades, e que a elucidação destes processos é fundamental para o entendimento de ambos os dramas, o privado e o social. Isto implica uma dimensão técnica, de reconhecimento, conceituação e explicação destes processos; mas, fundamentalmente, 
implica uma dimensão ética - uma preocupação constante com a honestidade do aspecto emancipador deste conhecimento.

\section{O trabalho ético de contar uma nova fábula}

“Comer ou ser comido, essa a lei da selva.

Definir ou ser definido, essa a lei do homem $^{8,}$

Mariza Corrêa lembra-nos: a etimologia da palavra fábula revela o seu sentido primeiro: ter a faculdade de falar [pág. 299]. Faculdade inerente à condição humana, mas facilmente usurpável entre os homens; em nossa sociedade, a bem poucos compete falar a verdade social sobre os acontecimentos.

Pertence à justiça, por direito - pela força do direito - a competência para falar a verdade sobre Roberto e seu crime. Por isto, seus manipuladores técnicos ${ }^{9}$ possuem o poder de transmitir esta competência, mandando falar os auxiliares da justiça, entre eles o psiquiatra. A fábula juspsiquiátrica é uma versão privilegiada, entre as incontáveis que narram e

\footnotetext{
${ }^{8}$ A frase, atribuída ao psiquiatra norte-americano Thomas Szasz, é citada in: Jaccard, R. A Loucura, Rio de Janeiro, Zahar, 1981 [Capítulo 3: Linguagem e Poder: Rotulagem Psiquiátrica e Invalidação Social, pág. 37].

${ }^{9}$ A expressão, utilizada por Mariza Corrêa, refere-se aos advogados, juízes e promotores, ou seja, àqueles que detém o conhecimento dos recursos legais possíveis em cada caso e também no âmbito de sua manipulação [Obra citada, nota 6 à pág. 25].
} 
interpretam um crime, porque está referendada de antemão, porque guarda o poder da verdade.

Um dos aspectos em que se manifesta a concretude deste poder é a absolvição, que legitima a conduta do réu, e a condenação, que propicia seu apenamento. A lei prescreve a individualização das penas, que se constituem basicamente pela privação ou restrição da liberdade, perda de bens, multa, prestação social alternativa, suspensão ou interdição de direitos. Será preciso lembrar que, para qualquer de suas modalidades, o apenamento sempre representa uma redistribuição da possibilidade ou do impedimento de exercer direitos bastante tangíveis, atingindo sempre mais que a pessoa do réu: tudo que dele é retirado, transfere-se a outrem - isto é mais óbvio no caso de perdas materiais, mas é igualmente válido para as demais; a prisão e seus agentes, por exemplo, tornam-se depositários do direito, ou seja, concretizam o poder, de dispor do corpo daquele que está apenado com a perda da liberdade.

Mas os efeitos do poder de verdade da fábula juspsiquiátrica não se esgotam neste primeiro aspecto de sua concretude. Do alto de seu poder, esta fábula dita ainda mais dois ordenamentos: o que deve ser o homem, e como deve ser julgado pelos homens. Pode-se dizer que o julgamento é o referendo social à fábula que, no caso dos homicídios, ritualiza-se na instituição do tribunal do júri popular. Mas o conteúdo desta fábula - a normatização do que é ser humano - e a fórmula de sua construção - o modo de coletar e selecionar os elementos que irão integrar seu conteúdo, ou seja, a definição dos papéis do policial, do advogado, do juiz, etc. - são sancionados automaticamente pelo mesmo processo. A fábula 
juspsiquiátrica converte-se na verdade socialmente aceita e, inquestionada, na verdade absoluta, na realidade - e o real é nada menos que o torno no qual são modeladas as subjetividades.

Ao vencedor, as palavras. Dele o privilégio de recitar a cultura e constituir-se em seu Mesmo, quando, deste lugar, define o seu Outro. Estamos tratando, então, de uma relação de alteridade, na qual o Mesmo e o Outro definem-se no bojo de um só processo. Penso que o crime de Roberto, como tantos outros acontecimentos, desafiava os porta-vozes da sociedade a formular um discurso capaz de compreendê-lo. A resposta possível seguiu o caminho de uma dupla desumanização, permitida pela redução de cada um dos membros reais daquela família ao desempenho do papel idealizado de pai, mãe, filho, irmã(o); por este procedimento, restaura-se o ideal da família moderna, e assim limita-se o alcance da denúncia de suas contradições que o crime tinha o potencial de assinalar; por este procedimento, as vítimas, seres humanos, desejantes, políticos, são travestidas em manifestações da Mãe, do Pai, da(o) Irmã(o); o homicida é travestido na manifestação do Epiléptico Condutopata. Fica como questão qual o modelo de homem, de relações humanas, daí deriva. Certo é que será influente na formação das subjetividades, será componente importante do assujeitamento do indivíduo à ordem social.

Michel Foucault, precisamente no momento que marca em sua obra a passagem ao nível genealógico de análise, enfatiza a centralidade do discurso nas disputas pelo poder: o discurso, diz ele, não é simplesmente aquilo que traduz as lutas ou os sistemas de dominação, mas aquilo 
porque, pelo que se luta, o poder do qual nos queremos apoderar ${ }^{10}$. Penso que esta afirmação guarda um potencial duplamente subversivo. Primeiro, porque sugere atenção às disputas pelo direito de falar e isto faz aguçar a escuta, permitindo ouvir coisas que, por serem inconvenientes ao sistema, a repressão/opressão reduziu a murmúrios. Segundo, porque nos alerta da valência de nosso próprio discurso: tudo quanto falamos, porque se incorpora à ordem do discurso, ingressa numa batalha em andamento; o sistema de dominação que experimentamos pode ser entendido como seu instante presente. Sabedores disto, a neutralidade não pode ser honesta resta-nos averigüar exaustivamente com que lado afinam-se nossas declarações; resta-nos assumir nosso compromisso na disputa.

Minha tentativa no presente estudo é fazer frutificar ambas as consequiências da lição de Foucault. Isto significa, para a primeira delas que apontei, realizar uma leitura do processo penal "O Estado contra Roberto..." que atente particularmente para as falas que nele aparecem enfraquecidas, interrompidas, interditadas. Assumo que minha própria dissertação é a defesa de um ponto de vista discordante quanto ao modo como a sociedade respondeu ao crime de Roberto, logo, é a proposição de alterações no modo de formular esta resposta; neste sentido, minha dissertação, como qualquer discurso, é política. Tratando de falar sobre aquelas respostas, é inevitável construir mais uma fábula sobre Roberto e seu crime. Como evitar que minha escrita perpetue o modo de assujeitamento - a usurpação do direito de falar, operada pela restrição do campo discursivo - que pretende contestar? Dito de outra maneira, como torná-la ética?

\footnotetext{
${ }^{10}$ Foucault, Michel A Ordem do Discurso, pág. 9 [Foucault, M. 1996].
} 
Parece-me que a única forma é fazê-la tribuna de tudo quanto foi calado nos discursos policial, juspsiquiátrico e jornalístico. Isto para mim adquire o significado de reintegrar, de dar direito a ser falado, tudo quanto cada falante - o policial, o jurista, o psiquiatra, o jornalista - teve que calar no discurso oficial sobre Roberto e seu crime. Claro que só posso fazê-lo na medida em que me aperceba do silenciamento; penso que é possível aperceber-se disto utilizando o conhecimento psicológico da experiência humana: por exemplo, diante da morte o homem experimenta a angústia e o medo - se isto não transparece no relatório de um inquérito policial, então foi calado. Este é um trabalho psicológico. Ponderar a função social das interdições que fizeram com que os sujeitos falantes calassem parte de sua experiência é um trabalho sociológico. Realizar conjuntamente ambos os trabalhos, sobre o mesmo objeto, é a tarefa da psicologia social em seu papel charneiro, de encruzilhada entre a psicologia e a sociologia [Maisonneuve, 1977]. Esta é a tarefa que ocupa os próximos cinco capítulos desta dissertação. Evidentemente este estudo dos discursos policial, juspsiquiátrico e jornalístico sobre o caso Roberto, para atingir simultaneamente os níveis da arqueologia e da genealogia, não poderá ser exaustivo.

O penúltimo capítulo será ocupado pela discussão do conteúdo da fabulação realizada pelos saberes $p s i$, sobre os homicidas violentos.

No último capítulo, à guisa de conclusão, procuro demonstrar a influência destas fábulas, veiculadas pela mídia e transmitidas nas relações interpessoais, sobre os processos de subjetivação, ou seja, de assujeitamento do indivíduo a um certo papel social - ao papel social monstruoso, psicopático, desempenhado por alguns homicidas. Neste sentido, representa um salto ensaístico dos resultados obtidos pela análise efetuada sobre o caso Roberto para o nível da ética foucaultiana, enquanto 
método de análise que visa a compreensão dos modos de subjetivação típicos da modernidade, em busca de uma resposta para minha questão: como é possível que um ser humano torne-se capaz de praticar tamanhas crueldades?

\title{
O trabalho fabuloso de construir um método
}

\section{para a psicologia social.}

\author{
... exterminando a Esfinge, a virgem cantadeira \\ de gadanhos aduncos, ele se ergueu como um bastião \\ diante de Tebas contra os assaltos da Morte ${ }^{11}$.
}

Precede a questão do método deste trabalho o entendimento sobre as relações da psicologia social com a Ciência. Felizmente, este entendimento pode ser fundeado ao largo da difícil questão sobre o status científico da psicologia social e mesmo das ciências humanas. Creio não haver dúvidas quanto ao fato de que as ciências humanas, entre elas a psicologia social, partilham o campo da Ciência: seus espaços, seus recursos, seus títulos, seu prestígio social. Se esta partilha é eqüanime, ou se a convivência é fraternal, não importa; é suficiente reconhecer que esta situação em si, embora não baste para conferir às ciências humanas o atributo da cientificidade, pressupõe expectativas e compromissos, de parte a parte, no sentido de que elas possam conhecer deste atributo. Não se ignora que, neste campo, busca-se metodicamente a verdade sobre algo,

\footnotetext{
${ }^{11}$ Antístrofe primeira do terceiro estásimo do Rei Édipo, de Sófocles (tradução de Jaime Bruna).
} 
que a qualidade desta verdade supõe-se relacionada com o rigor do método empregado em sua busca, e que a observação constitui-se seu método por excelência $^{12}$.

Com tudo isto a psicologia social, como as demais ciências, não pode romper sem injuriar-se. Também não pode, sem ser iníqüa, abdicar de sua competência para buscar a verdade sobre o objeto que reinvindica e guarda; compete ao psicólogo social empreender esta busca, o que implica deliberar sobre seu sentido, sobre para onde dirigir sua observação. Esta não é uma de suas prerrogativas: é seu dever inescusável. Deve o psicólogo social conhecer da construção de sua ciência, da definição de seu objeto, seu objetivo e seu método, como deve conhecer da Ciência e de suas exigências, e das humanidades e de suas controvérsias.

Nisto se pode ancorar o entendimento pretendido: enquanto honra, através de seus membros, tais compromissos, a psicologia social mantém-se digna de permanecer no campo da Ciência; enquanto este campo permanecer configurado, compete a todos e a cada um de seus membros definir e judiciar sobre a distribuição de seus atributos. Enquanto partilha deste campo, falando ou calando, ninguém se pode furtar a estes compromissos científicos.

Em matéria das ciências humanas, a constituição de uma porção da realidade enquanto objeto de estudo faz-se mediante uma atitude consciente do pesquisador, que implica escolha e decisão amparadas em duas ordens de critérios:

Na primeira ordem, para que algo seja constituído como objeto de estudo, é preciso que um sujeito, ao defrontar-se com o mundo, perceba

\footnotetext{
${ }^{12}$ A experimentação inclui-se como caso especial. Trata-se, evidentemente, de uma observação controlada.
} 
nele alguma coisa duvidosa, incompreensível, que o intrigue e o leve a prestar-lhe atenção. Além disso, será necessário que este sujeito delimite a extensão desta coisa intrigante, que postule sua possível composição interna, as relações de suas várias partes entre si e com seu todo, e ainda suas relações com as coisas do mundo que lhe parecem inteligíveis. Portanto, o sujeito parte do que não sabe mas, para delimitá-lo, apenas pode valer-se daquilo que supostamente já sabe. Logicamente, isto implica que o recorte do objeto de estudo não se faz por sua natureza ou características, mas pelo montante de saber disponível para o pesquisador naquele momento.

$\mathrm{Na}$ segunda ordem, é preciso que este sujeito mobilize e invista suficiente energia psíquica para transformar esta incompreensão num projeto de pesquisa, e executá-lo. Ao recortar a realidade para constituir seu objeto de estudo, o sujeito move-se num campo pleno de alternativas, e em suas escolhas há de guiar-se em larga medida pela articulação entre sua percepção do mundo (coisa percebidas como naturais ou como estranhas, duvidosas ), seus sentimentos desejantes (desejo de compreender algo que lhe escapa, angústia diante do desconhecido, piedade ou rancor para com determinado grupo social, vaidade científica, ambição), e uma determinada situação social (disposição acadêmica para acatar e/ou custear sua pesquisa, interesse político e/ou relevância social do tema, etc.).

Conjugando estas duas ordens de critérios, é forçosa a conclusão de que a delimitação do objeto de estudo nas ciências humanas tem menos de descoberta ou reconhecimento dos limites dados pela natureza do objeto, que de elaborações das possibilidades deixadas ao sujeito pelas condições momentâneas dos jogos individuais e coletivos do desejo e do poder para o exercício de sua razão. Em outras palavras, o pesquisador terá de lidar com seu objeto de estudo mediante os recursos disponíveis no 
momento, os que detém enquanto indivíduo, e os que estão presentes em seu campo de atuação.

Tudo isto continua valendo para as sucessivas etapas da pesquisa, até sua conclusão, o que equivale a dizer que o discurso científico, ao enunciar a verdade encontrada em um objeto está enunciando também, embora veladamente, uma verdade sobre o realizador da pesquisa, compreendido em suas dimensões pessoal e coletiva - enquanto indivíduo e enquanto agente engajado num campo científico determinado, com suas prescrições teóricas e práticas, condutas padronizadas e configurações políticas. Equivale a dizer ainda que, junto com o conhecimento científico sobre o objeto, constróem-se duas coisas bem distintas dele, embora os três constructos permaneçam sempre vinculados e solidários entre si: uma, é a própria existência do objeto, conforme foi configurado, enquanto idéia que passará a integrar não apenas os raciocínios e discursos daquele campo científico que a gerou mas, muitas vezes, será apropriada também por outros campos de saber, orientando decisões e práticas pessoais, grupais e sociais. Outra, é a ciência mesma, cujos contornos são definidos precisamente a partir das pesquisas concretas que logram abrigar-se sob sua rubrica. Então, cada estudo empreendido, ao ser acolhido no campo daquela ciência, vem professar um conjunto de prescrições sobre quais sejam seus limites metodológicos e teóricos, bem como uma pauta das condutas e procedimentos adequados aos seus membros.

Para a psicologia social, quais seriam estes limites? Responder a isto implica estabelecer quais são os objetivos e métodos próprios a esta ciência, e isto se pode fazer por dois caminhos: um, o resgate de sua história e o arrolamento dos trabalhos realizados em seu campo, a fim de traçar um panorama atual de suas atividades. Mas este caminho exige, no final, que seja estabelecida a posição de cada trabalho em relação ao 
demais atinentes ao campo da psicologia social, subordinando-o a uma tendência ou corrente de práticas majoritárias. Penso que uma tal operação de subscrição do singular ao majoritário tende a apagar a contribuição específica da singularidade, tende a escamotear as diferenças, os conflitos, as disputas até, projetando uma imagem ilusória de hegemonia.

Outro caminho possível - quase o inverso do primeiro - é a afirmação da autonomia de cada pesquisador, e da legitimidade de sua forma singular de investigação, fundamentada simplesmente em sua formação específica nesta área. Esta afirmação levaria a um outro modo de estabelecer os objetivos e métodos próprios a esta ciência, pautados não mais pela busca de uma verdade universal e atemporal sobre o objeto busca que se confunde com o desejo de "depurar" o sujeito cognoscente, até o impossível ideal da objetividade. O objetivo seria, então, a explicitação da compreensão do pesquisador sobre a psicologia social, tanto quanto sobre o fenômeno que se propõe estudar, e a aplicação desta compreensão no programa da pesquisa, num processo contínuo e interminável de retomadas significativas, de redefinições comprometedoras.

Naturalmente, esta mudança de objetivos determinaria profundas mudanças no método, no sentido de exigências mais específicas quanto à formação do pesquisador, enfatizando o desenvolvimento de uma visão e uma atitude auto-críticas, e quanto aos procedimentos empregados na pesquisa, enfatizando sua dupla função: sistematizar a aplicação do método ao objeto, tanto quanto ao pesquisador e à própria psicologia social. Estes procedimentos não poderiam mais, por seu silêncio, relegar aos epistemólogos a tarefa de analisar as concepções prévias do pesquisador e suas implicações sobre o método e os resultados da pesquisa. Ao contrário, deveriam assumir explicitamente esta tarefa, que constitui um exercício de 
auto-crítica fundamental, intrínseco ao trabalho de pesquisa, cuja realização condiciona sua qualidade posto que apenas esta reflexão pode esclarecer melhor - embora nunca completamente - as origens e os limites da compreensão adquirida sobre o objeto de estudo, circunscrevendo a validade do discurso que a relata e comprometendo, epistemológica e éticamente, neste discurso o seu autor. Objetivo e método da psicologia social seriam, então, como que uma reedição perpétua e descrente do "conhece-te a ti mesmo".

As interações entre os indivíduos e as coletividades envolvidas com as investigações, relatos e julgamento de um homicídio encontram-se consubstanciadas nos discursos juspsiquiátrico e jornalísticos registrados sobre o caso. Assim, estes discursos guardam espessa matéria de interesse para a psicologia social, porquanto retratam uma forma assumida por seu objeto, oferecendo-a à investigação.

O método deste estudo, portanto, resume-se na observação, ou seja, numa leitura crítica, do discurso que relata, interpreta e explica o crime de Roberto.

A primeira condição de rigor para esta observação é que o mesmo esforço de crítica seja exercido sobre o discurso que eu própria estou construindo, à medida que o faço, embora, evidentemente, isto não possa ser explicitado na escrita sob pena de eternizá-la; em meu próprio discurso, o rigor possível é a assumpção ética de meu comprometimento subjetivo nele.

Há uma outra ordem de condição de rigor, que se refere não mais a qual discurso deve ser observado, mas a como deve ser observado, ou seja, refere-se ao instrumental empregado nesta observação. A análise do discurso, conforme foi preconizada por Michel Foucault, serviu-me para 
perceber as relações de poder entre as diversas instituições encarregadas de falar a verdade sobre o crime, bem como as questões relativas ao regime de verdade que permeia a construção dos discursos de interesse; por outro lado, contribuições mais recentes neste campo, apresentadas por Dominique Maingueneau em Novas Tendências em Análise do Discurso [Maingueneau, 1989] e durante o curso Análise do Discurso: Correntes Pragmáticas e Teoria da Enunciação [IP-USP/ PSA-5830, 1997], ofereceram elementos para a identificação, no discurso, de questões relativas ao seu contexto, às suas conotações implícitas, às relações interindividuais patenteadas por estas conotações, etc.

Naturalmente, pela minha formação, a psicanálise também valeume como instrumento importante para a análise, sensibilizando-me para a percepção de lacunas, fissuras, contradições, equívocos, para aquilo que possa sinalizar a necessidade de redobrar a atenção, de aprofundar o exame. Mas creio que sua maior contribuição deriva do treino para a autoobservação, para a consciência dos próprios sentimentos, pista ainda melhor para orientar-se na sondagem do terreno humano. Penso que a consideração de minhas reações totais, inclusive aquelas de ordem afetivoemocionais, é condição de possibilidade para acessar o conteúdo da interação humana encerrado no texto. Não me detenho, porém, em eleger o modo de operar estes instrumentos, ou mais explicitamente, em filiar-me a uma ou outra escola psicanalítica. A idéia não é psicanalisar os discursos de interesse - o que sequer teria sentido, posto que não posso interagir com um texto - mas tão somente servir-me das reflexões psicanalíticas para apurar a leitura, como na clínica se busca apurar a escuta.

Finalmente, há uma terceira ordem de condição de rigor, correlacionada com a atitude necessária na investigação em ciências humanas. Primeiro, a importância de manter-se uma atitude intelectual 
zelosa do conteúdo denotado e conotado pelos conceitos e termos empregados nas explanações teóricas, sob pena de a teorização cristalizar expressões e sentidos, apartados de qualquer significação genuína por parte do sujeito que os repete. Segundo, a importância de manter-se a preocupação com preservar a integralidade do objeto, com sua apreensão global. Sob certo enfoque, esta é uma condição irrealizável: não há como manter a pretensão de conhecer tudo quanto sustenta nosso linguajar, e ultrapassa a possibilidade humana apreender um processo humano em sua totalidade.

Entretanto, não é lícito ao cientista social deixar de criticar a linguagem - penso, até, que não é outro o nosso ofício. Quando utilizamos as definições propostas por outrem, estamos reafirmando-as; mas o emprego de sua nomenclatura faz que se dilua nosso compromisso com esta reafirmação. Por isto, deveríamos sempre ressimbolizar a verdade que afirmamos e evitar as citações; tento fazê-lo, na medida do possível.

Também não podemos ignorar que, se recortamos um processo humano, à maneira das ciências ditas naturais, perdêmo-lo inteiramente. Os processos humanos são rigorosamente complexos, e seus componentes são rigorosamente integrados. Compete ao psicólogo social afirmar esta integralidade no delineamento de sua investigação, e tratar sempre de buscar compreendê-la, no grau possível.

Isto é precisamente o que recomenda e justifica, neste trabalho, o "estudo de caso"; trata-se de uma tentativa de integrar as diversas respostas oferecidas a um caso real, evitando imprimir-lhes, através de uma seleção arbitrária, um recorte excessivamente mutilador. Deve ser notado, porém, que nem todos os discursos produzidos sobre o caso puderam ser coletados 
para análise, alguns por sua natureza efêmera, outros pelos obstáculos práticos que se impõem à pesquisa acadêmica.

O discurso jurídico esteve representado pelos autos do processo judicial $O$ Estado Contra Roberto..., que culminou no julgamento pelo $1^{\circ}$ Tribunal do Júri da Capital de São Paulo. Como amostra do discurso policial, foram utilizados os autos do Inquérito Policial, constantes no processo penal. O discurso juspsiquiátrico compreendeu os autos apensos, referentes ao Incidente de Insanidade Mental, particularmente o Laudo da perícia psiquiátrica, e os depoimentos em juízo do perito Dr. Guido Arturo Palomba; também utilizei a apresentação do caso em seu livro Loucura e Crime, publicado cerca de 11 anos após a perícia. O material jornalístico compilado sobre o caso compreende 42 reportagens sobre o caso, publicadas pelos jornais Notícias Populares (18 matérias) e Folha de São Paulo (23 matérias), e pela revista Veja (1 matéria), num período que abrange os 6 anos seguintes ao crime, além de uma entrevista de Roberto gravada em fita magnética e transcrita nos autos do processo penal.

Todo este material é público: o jornalístico por sua própria natureza; o policial, o juspsiquiátrico e o jurídico, por princípio e por $\operatorname{lei}^{13}$. Não obstante, optei por suprimir os endereços completos e os nomes de família citados no processo. Os nomes das pessoas públicas que comentaram o caso através da imprensa, entretanto, mencionei-os inteiros, acompanhados dos títulos que os jornais atribuíram-lhes na ocasião.

\footnotetext{
${ }^{13}$ Reza a Constituição brasileira de 1988, em seu artigo $5^{\circ}$, parágrafo LX, que a lei só poderá restringir a publicidade dos atos processuais quando a defesa da intimidade ou o interesse social o exigirem. Especialmente o julgamento pelo tribunal do júri deve ser realizado com as portas abertas.
} 
Capítulo 2:

As confabulações sociais sobre homicídios violentos 


\section{As confabulações sociais sobre os homicídios violentos ${ }^{14}$}

$\mathrm{O}$ ato de matar uma pessoa recebe diferentes designações, de acordo com o contexto de sua ocorrência e de sua interpretação: assassinar, executar, sacrificar. O direito designa-o pela palavra "homicídio"; o Código Penal brasileiro tipifica como crime de homicídio a conduta de "matar alguém". Este é, portanto, o enfoque obrigatório para o presente estudo. A falta de familiaridade com o modo peculiar de ordenamento do discurso jurídico pode criar embaraços à compreensão dos argumentos que serão desenvolvidos a respeito do caso de Roberto.

Mariza Corrêa, em seu livro já citado, faz uma interessante apresentação dos atores jurídicos e de suas respectivas estratégias de investigação, acusação e defesa, e traz ainda um quadro sinóptico sobre as etapas formais do processo penal de homicídio, cuja leitura pode ser bastante útil a quem ignora inteiramente o assunto [Corrêa, obra citada. Capítulo 1: Os construtores da fábula. Págs. 31-84].

Seria impertinente deter-me a realizar aqui uma introdução ao direito penal; entretanto, não poderia deixar de informar sobre alguns aspectos essenciais do processamento judicial dos casos de homicídio em nossa sociedade. A solução que encontrei aparece neste capítulo como uma tentativa de apresentar concomitantemente as várias respostas sociais ao homicídio, onde se inclui a resposta do direito. Em certa medida, isto servirá para resumir o modo de ação da justiça criminal, com a vantagem

\footnotetext{
${ }^{14}$ Emprego a expressão homicídios violentos para distingüi-los dos homicídios culposos e eutanásias. Com certa licença, pode-se considerar aí outras situações de morte que o Código Penal tipifica sob outras rubricas, como o latrocínio e o seqüestro seguido de morte.
} 
de servir também como introdução à análise crítica de sua aplicação ao caso de Roberto.

Em linhas gerais, a busca da verdade e a produção de conhecimento acerca dos homicídios violentos registrados em nossa sociedade é empreendida basicamente em duas frentes: uma, repressiva - a polícia repressiva (hoje, a polícia civil) e a justiça criminal, e outra, compreensiva - a criminologia e seus diversos ramos, entre eles a sociologia e a psicologia criminais ${ }^{15}$.

Como geralmente os dados utilizados para as demais análises são coletados e organizados pelas instâncias repressivas, convém expor, inicialmente, o modo próprio de ordenamento de seus discursos.

Basicamente, tudo quanto venha a ser dito sobre um homicídio, no âmbito repressivo, estará referido a três entidades relativamente abstratas, quais sejam o autor (criminoso, homicida, indiciado, réu, etc., conforme o prisma pelo qual é tomado), a vítima e o fato. Importa notar isto, pois este ordenamento tende a reproduzir-se em todos os demais discursos acerca do assunto, em todos os campos de saber. E, no entanto, tratam-se estas entidades de construções do Direito Penal, necessárias à consecução de seus fins repressivos, que nem sempre auxiliam a compreensão do fenômeno em outras áreas de investigação.

O que o Direito Penal zela por estabelecer e manter, em face da sua primordial finalidade repressiva, é uma rígida distinção entre autor e vítima, que exige a depuração destas duas entidades, realizada mediante uma operação intelectual com vistas a preservar em toda a plenitude a liberdade do arbítrio do agente, em relação à conduta criminosa - condição

\footnotetext{
${ }^{15}$ Neste capítulo, estarei utilizando a nomenclatura conforme aparece em [Mirabete, 1996]; não me deterei, portanto, a discutir a propriedade da expressão psicologia criminal.
} 
necessária de sua censurabilidade e punição - enquanto preserva a passividade da vítima, ao menos até um limiar que não comprometa o enquadramento da conduta do agente na pauta da antijuridicidade. Para ilustrar este ponto, pode-se observar o delicado equilíbrio destas duas posições quando se admite que a vítima tenha despertado uma violenta emoção no autor, mediante uma provocação injusta, e que o reconhecimento desta circunstância deverá atenuar a pena pelo homicídio; ao mesmo tempo, não se pode admitir que o comportamento da vítima tivesse o poder de coagir irresistivelmente o agente, sob pena de restar inócua a tutela penal da vida desta vítima, já que a coação irresistível exclui a culpabilidade e, logo, a punibilidade do agente. Quando esta depuração não é logicamente possível por ser a conduta da vítima causa inarredável da conduta criminosa do agente, como no caso da legítima defesa, o que se extingue é o próprio crime, pela exclusão da antijuridicidade do fato, ou seja; não há mais que se falar em homicídio, e menos ainda em vítima.

Isto posto, vislumbra-se que uma das conseqüências de admitirse, nos demais campos do saber, esta distinção que configura as entidades jurídicas de autor e vítima, é encampar-se uma depuração justificável para as finalidades do Direito Penal, mas muitas vezes inadequada para as análises de outra natureza. Para cumprir suas finalidades, a justiça criminal opera um recorte que destaca autor e vítima do contexto real onde se travou o embate que resultou no homicídio; as relações concretas entre ambos são abstraídas, e cada um destes protagonistas passa a figurar como puras manifestações do livre-arbítrio e do sofrimento, respectivamente. O ordenamento do Direito Penal, generalizando-se nos discursos político, jornalístico, literário, bem como no falar cotidiano das pessoas comuns, 
tece a verdade aceita sobre os crimes particulares e a criminalidade; tornase assim bem difícil criticar os limites destas verdades.

A expressão Direito Penal designa simultaneamente a "reunião das normas jurídicas pelas quais o Estado proíbe determinadas condutas (tidas como profundamente lesivas à vida social), sob ameaça de sanção penal, estabelecendo ainda os princípios gerais e os pressupostos para a aplicação das penas e das medidas de segurança" e "o sistema de interpretação da legislação penal, ou seja, a Ciência do Direito Penal, conjunto de conhecimentos e princípios ordenados metodicamente, de modo que torne possivel a elucidação do conteúdo das normas e dos institutos em que eles se agrupam, com vistas na sua aplicação aos casos ocorrentes, segundo critérios rigorosos de justiça” [Mirabete, 1996. Pág. 19].

O Direito Penal ocupa-se do homicídio, como já foi dito, com finalidade essencialmente repressiva e secundariamente ética. De sua caracterização, conforme apresentada por Júlio Fabbrini Mirabete, pode-se destacar dois aspectos de interesse para nossa discussão: primeiro, o tratarse de ciência cultural e normativa, preocupada com o dever ser (moral) e com a norma (legal), como dados indiscutíveis, a cujos ditames deve dobrar-se qualquer indivíduo, em qualquer circunstância. Não há, em regra, na apreciação de um crime concreto, abertura possível para a consideração de elementos ou circunstâncias não previstos anteriormente. Em outras palavras, o episódio real não deve ser tomado pelo que é, mas pelo que deveria ser, em obediência às normas vigentes. Por exemplo, não cabe considerar, para julgar a imputabilidade, a emoção ou paixão que motivou o sujeito no momento do crime, mas tão somente sua capacidade de 
entender o caráter ilícito de sua conduta e de conduzir-se de acordo com este entendimento, uma vez que o Código Penal não admite que uma emoção ou paixão altere momentaneamente a capacidade de discernimento ou de autodeterminação do indivíduo ${ }^{16}$, salvo nos casos de uma emoção causada por "injusta provocação da vítima" - que não exclui a imputabilidade, mas apenas pode atenuar o crime ou reduzir a pena. $\mathrm{Ou}$ seja: não cabe investigar se a emoção ou paixão alterou momentaneamente o discernimento ou a capacidade de autodeterminação do indivíduo, mas apenas acatar que, segundo o código, não deveria ter alterado.

Um segundo aspecto a considerar é o caráter predominantemente sancionador do Direito Penal, uma vez que reforça a tutela jurídica de bens e instituições protegidos por leis extrapenais (por exemplo, protege a instituição familiar adotando como agravante genérica para qualquer crime a circunstância de haver sido cometido contra cônjuge, ascendentes, descendentes ou irmão). Pode-se ampliar a consideração deste caráter sancionador, reconhecendo que em larga medida o Direito Penal acata e reproduz a ideologia, as exigências e os costumes da sociedade. Isto poderia ser apontado em qualquer área ou instrumento do Direito Penal, mas fugiria aos limites e objetivos deste trabalho fazê-lo exaustivamente. Basta, para exemplificar, mencionar alguns detalhes do Código Penal, que pela ambigüidade sinalizam sua origem eclética e política, em meio às controvérsias, preconceitos, comoções, interesses e disputas sociais.

Assim, temos que emoções ou paixões não são admitidas como excludentes da culpabilidade do agente mas, não obstante, podem tornar privilegiado o crime, atenuando-lhe as penas, quando estiverem

\footnotetext{
${ }^{16}$ Segundo o Artigo 28, inciso I do Código Penal, não excluem a imputabilidade penal a emoção ou a paixão.
} 
relacionadas a "motivos de relevante valor social ou moral"17, ou ao contrário, serem tomadas como circunstância agravante ou mesmo qualificadora, se forem consideradas como anti-sociais. É o caso, por exemplo, do crime de homicídio, que qualifica-se quando praticado "mediante paga ou promessa de recompensa, ou por outro motivo torpe", sendo torpes os motivos inspirados pelas paixões tidas como anti-sociais, como a cobiça e a ambição, ou ainda o latrocínio, para o qual o desejo de apropriar-se da coisa alheia vem mesmo tipificar o crime ${ }^{18}$. Note-se que estas circunstâncias elevam a conduta criminosa de matar alguém à categoria de crime hediondo, com implicações práticas importantes, relativas às condições em que se processará o julgamento do réu, e ao montante das penas aplicáveis. Note-se, também, quão controversa pode ser a apreciação do caráter social ou anti-social das paixões, como o amor, a piedade, o patriotismo, a cobiça, a ambição, etc., e quanto da atribuição de valor ou desvalor social a cada uma delas depende de manipulações da opinião pública, das transformações dos costumes, da ética, etc. ${ }^{19}$.

A Criminologia, por sua vez, ocupa-se do crime em geral, logo também do homicídio violento, com finalidade basicamente compreensiva. Nas palavras de Mirabete, a criminologia estuda "a causação do crime, as medidas recomendadas para tentar evitá-lo, a pessoa do delinqüente e os caminhos para sua recuperação", valendo-se do "conjunto de estudos que compõem a enciclopédia das ciências penais". Enquanto no Direito Penal a preocupação básica é dogmática, nela é causal-explicativa: "o crime é

\footnotetext{
${ }^{17}$ De acordo com o Artigo 121, parágrafo $1^{\circ}$, do Código Penal, é privilegiado o homicídio praticado por relevante valor moral [ eutanásia, por exemplo].

${ }^{18}$ O latrocínio - roubo seguido de morte - é previsto no artigo 157, parág. $3^{\circ}$ do Código Penal, estando, portanto, sob a rubrica dos crimes contra o patrimônio.

${ }^{19}$ Desnecessário mencionar os chamados “crimes de amor", e o quanto de injustiça e prepotência neles foram denunciadas, especialmente pelo movimento feminista.
} 
considerado como fato humano e social; o criminoso é tido como ser biológico e agente social, influenciado por fatores genéticos e constitucionais, bem como pelas injunções externas que conduzem à prática da infração penal, e, numa postura moderna, agente de comportamento desviante, ,'[pág. 20].

Mas isto não significa que Direito Penal e Criminologia sejam áreas de saber estanques e independentes; ao contrário, os conhecimentos criminológicos exercem influência sobre o sistema jurídico assim como o ordenamento jurídico muitas vezes baliza os estudos realizados no âmbito da criminologia, por exemplo, quando são aceitas definições legais das condutas criminosas e de suas gravidades. Também ocorre uma imbricação entre os dois campos no posicionamento crítico da criminologia, quanto aos princípios e práticas do Direito Penal.

Aceita-se, geralmente, que a criminologia está constituída por dois grandes ramos de disciplinas: a biologia criminal, que inclui os estudos da antropologia, psicologia e endocrinologia criminais; e a sociologia criminal, que trabalha com a estatística criminal e inclui, ainda, os estudos de vitimologia e de biotipologia criminal, além da análise das experiências resultantes da adoção, por parte do Estado, de diferentes políticas criminais. Mirabete resume a atuação da criminologia na frase: " $O$ estudo do delito como fenômeno social (...) é do âmbito da Sociologia Criminal, assim como o crime, como fato individual, pertence ao campo de observação da Biologia Criminal”, mesmo reconhecendo a incontestável interpenetração dessas ciências, para o estudo da gênese do delito [pág. 32].

De fato, verifica-se uma ruptura nas análises oriundas da Sociologia e da Biologia criminais, que não se justifica inteiramente pela diversidade de métodos e objetos. Embora estudiosos de ambos os campos 
reconheçam, nas introduções teóricas de seus trabalhos, a necessidade de romper os limites convencionais das disciplinas acadêmicas para melhor compreender crime e criminoso, a regra geral é que estas considerações não frutifiquem em procedimentos, conceituações e conclusões que promovam um olhar mais abrangente sobre a criminalidade, sob o qual pudessem ser desvendadas as relações entre o fato criminoso individual e o seu contexto social mais amplo, e vice-versa.

Em 1984, Luiz Carlos da Rocha afirmava, em tom animador, parecer "que muita gente acredita que a questão da criminalidade, entre outras, não pode ser bem compreendida sob os restritivos limites de uma ou outra das numerosas ciências em que o conhecimento do Homem e de suas relações foi arbitrariamente retalhado (...) estamos todos reaprendendo que a divisão e isolamento das ciências humanas nunca teve por objetivo descobrir, mas ocultar as questões incômodas em vias de serem conhecidas" [Rocha, 1984]. Mais de uma década depois, penso que ainda é um desafio realizar esta ampliação do olhar.

Mas é importante perceber que a ocultação da verdade, embora resulte da fragmentação das ciências não é seu objetivo, mas decorrência quase fortuita de seu modo de construção e desenvolvimento histórico. Romper com o isolamento é um desafio arriscado, pois não se pode ter a pretensão de abarcar o conhecimento acumulado nas várias frentes científicas, e são escassos, ainda, os recursos teóricos de articulação entre estes conhecimentos. Além disso, a construção do conhecimento científico ainda se pauta por regras acadêmicas que corroboram, e assim promovem, a divisão disciplinar. 
Por tudo isto, penso que o estudo do crime, nesta perspectiva ampliada, deve ser a um só tempo modesto, pois trata-se de arriscar um novo olhar que tenta abranger elementos até então dispersos e, por isto, desconhecido em suas relações recíprocas; e ambicioso, pois visa estabelecer um novo enfoque, capaz de permitir a realização das pretensões de unificação dos saberes acerca do objeto. Inclino-me a concordar com Luiz Miller de Paiva, sem prejuízo das críticas que venha a fazer-lhe ao longo deste trabalho quanto ao seu enfoque da conduta homicida, quando afirma que "a solução preferível para a atual dicotomia entre as práticas clínicas $e$ as teorias sociológicas, seria o ensino integrado $e$ interdisciplinar da criminologia. As escolas existentes ou são predominantemente clínicas ou sociológicas ou de ciência normativa [...] a psicanálise, psiquiatria, psicologia, sociologia, em nível acadêmico, e a criminologia clínica e a teórica, em nível das ações práticas, tanto no campo preventivo como no penitenciário, devem fundir-se em um todo integrado para permitir à criminologia absorver as tarefas que a sociedade lhe impõe” [Paiva, 1981]. O mesmo raciocínio parece-me válido para as tarefas próprias da investigação teórica. Especialmente no campo da psicologia social, é imperioso desenvolver procedimentos e recursos teóricos integrados, que permitam compreender as relações entre $o$ homicídio particular e o fenômeno social do crime, especialmente dos homicídios violentos.

Aplica-se o Direito Penal às ocorrências criminosas valendo-se das chamadas ciências auxiliares: a medicina legal, a criminalística (ou polícia científica) e a psiquiatria forense. Antes de chegar à discussão do papel destas ciências auxiliares será necessário informar e discutir, ainda 
que superficialmente, a longa e complexa seqüência de eventos posta em marcha quando um homicídio é conhecido pela autoridade policial.

O julgamento dos crimes dolosos contra a vida - homicídios, abortos, infanticídios e auxílio, induzimento ou instigação ao suicídio - é de competência do Tribunal do Júri. Destes, apenas o homicídio e o aborto praticado sem o consentimento da gestante são inafiançáveis. Escapam à competência do júri os crimes culposos (não intencionais) contra a vida e o latrocínio, que é considerado crime contra o patrimônio e não contra a vida.

O homicídio qualificado está incluído entre os crimes hediondos a partir da Lei 8.930 de 6.9.94, o que o torna insuscetível de anistia, graça, indulto, fiança e liberdade provisória. A pena aplicada por tal crime deve ser executada integralmente em regime fechado e o livramento condicional só é permitido após o cumprimento de dois terços da pena, se o agente não for reincidente específico em crime desta natureza.

Note-se, então, que a convicção de que houve dolo (o agente quis o resultado ou assumiu o risco de produzi-lo) na prática de um homicídio traz, além do aumento da pena, importantes consequiências para o respectivo processo penal: julgamento pelo júri e insuscetibilidade de fiança. A afirmação de circunstâncias qualificadoras torna-o hediondo, acrescentando maiores conseqüências processuais e penais. Qualificam um homicídio, conforme o Artigo 121, parágrafo $2^{\circ}$ do Código Penal, ser praticado: I. mediante paga ou promessa de recompensa ou por outro motivo torpe, II. por motivo fútil, III. por meio insidioso ou cruel, IV. de modo que impossibilita a defesa da vítima e V. visando ocultar outros crimes praticados pelo agente. 
Note-se, também, que o caráter hediondo de um crime, mesmo do homicídio, não deriva, legalmente falando, de atentar contra a vida bem preciosíssimo em nossa cultura. Outros crimes contra a vida recebem tratamento processual e penal bem mais brandos, e mesmo um homicídio doloso não será considerado hediondo se não for qualificado. Aliás, apenas em 1994, pela Lei 8.930, foram eles incluídos entre os crimes hediondos, juntamente com os homicídios praticados em atividades típicas de grupos de extermínio ${ }^{20}$.

Verificada a ocorrência do homicídio, compete à autoridade policial instaurar o Inquérito, que tentará identificar a vítima, apurar as circunstâncias do fato e conhecer sua autoria. Nestas tarefas, será auxiliado pela Medicina Legal e pela Criminalística. Caberá à Medicina Legal responder, a partir do exame necroscópico do corpo da vítima, fundamentalmente, aos quesitos: a) Houve morte?, b) Qual a causa?, c) Qual a natureza do agente, instrumento ou meio que a produziu? d) Foi produzida por meio de veneno, fogo, explosivo, asfixia ou tortura, ou por outro meio insidioso ou cruel? As respostas médicas a estas perguntas constituirão, no processo, provas da tipicidade da conduta do agente, do nexo causal entre esta conduta e o evento morte e da possível qualificação, por meio ou modo insidioso ou cruel, do homicídio. Eventualmente, deve ainda a Medicina Legal proceder à identificação de pessoas e à verificação

\footnotetext{
${ }^{20}$ Entretanto, o latrocínio, a extorsão qualificada pela morte, a extorsão mediante seqüestro e na forma qualificada, o estupro, o atentado violento ao pudor, a epidemia com resultado morte, o envenenamento de água potável ou de substância alimentícia ou medicinal qualificado pela morte e o genocídio, tentado ou consumado, eram assim considerados desde 25.7.90, nos termos da Lei 8.072, e a eles se equiparam, segundo o Artigo $5^{\circ}$, inciso XLIII da Constituição Federal, de 1988, a tortura, o tráfico ilícito de entorpecentes e drogas afins e o terrorismo. Para Antonio Lopes Monteiro, a inclusão de uma modalidade de crime na categoria legal de hediondo tem servido, basicamente, para responder ao clamor social quando as autoridades não logram concretizar medidas preventivas e repressivas eficazes em seu combate [Monteiro, 1997].
} 
de lesões físicas em quaisquer dos envolvidos no crime, bem como prestar outros serviços de sua competência no sentido de auxiliar seu esclarecimento.

Quanto à Criminalística, fica-lhe a incumbência de verificar e atestar as informações, hipóteses ou suspeitas, levantadas pela investigação policial, através de exames periciais de instrumentos, armas, projéteis, resíduos, materiais, etc., relacionados com a cena e os resultados do crime.

Boa parte de tudo quanto venha a ser afirmado sobre o crime, no processo judicial posterior, estará fundamentado sobre os laudos periciais da Criminalística e da Medicina Legal. Entretanto, parte considerável do Inquérito Policial assenta-se sobre a argüição preliminar das testemunhas, a investigação sobre a vida pregressa dos envolvidos, notadamente do acusado, e a elaboração de hipóteses sobre os aspectos obscuros do crime, especialmente sobre seus motivos. Naturalmente, estas hipóteses servirão para orientar, passo a passo, as investigações e as solicitações de exames periciais.

Baseado nas conclusões do Inquérito Policial, deve o promotor público oferecer ao juiz a Denúncia do acusado, desde que reste atestado, pelo trabalho policial, que houve um crime doloso contra a vida e que há indícios de ser o acusado o autor deste crime. Também devem ser ponderadas eventuais circunstâncias que excluam a ilicitude da conduta, como a legítima defesa ou o estado de necessidade. 
Segundo afirma Sérgio Adorno, com base na análise de 297 processos penais instaurados e julgados em um dos tribunais de júri da capital de São Paulo, no período de janeiro de 1984 a junho de 1988, "constitui estratégia da promotoria caracterizar a ocorrência em sua maior gravidade, postura que ela procura manter até o desfecho final do processo. Não raro, vale-se das circunstâncias qualificadoras contidas no próprio Código Penal (...). Em contrapartida, a defensoria cuida de atenuar as circunstâncias do crime, buscando desqualificá-lo (...).É, por conseguinte, em torno dessa questão - presença ou ausência de qualificadoras - que se apegam os debates no tribunal de júri, razão por que se apela com freqüencia ao modo de vida e às características de personalidade dos protagonistas" [Adorno, 1994]. As mesmas conclusões foram alcançadas antes, por Mariza Corrêa, sobre o tribunal do júri de Campinas, no interior do estado.

Evidentemente estas estratégias de acusação e defesa, além de dependerem mais da astúcia e habilidade dos promotores e advogados que de fatos, tendem a potencializar os efeitos das hipóteses policiais que anteriormente orientaram as investigações, na medida que acatam e enfatizam aspectos de difícil avaliação objetiva, tais como motivos, conduta moral dos envolvidos, emoções que permearam o crime, etc., e que não são passíveis de apreensão em provas cabais. Neste processo, além da seletividade do olhar e dos preconceitos, pessoais e profissionais, dos policiais, também acabam por serem referendadas as hipóteses, preconceitos, opiniões, e toda sorte de avaliações pessoais das testemunhas que instruíram o inquérito. 
Denunciado o acusado e não havendo motivo legal para sua pronta absolvição - os casos de exclusão de ilicitude ou de culpabilidade deverá o juiz julgar o conteúdo e os aspectos formais da Denúncia, e a pertinência do caso ao âmbito de competência do Tribunal do Júri. Para tanto, interrogará o acusado, ouvirá testemunhas e, se achar necessário, solicitará investigações e perícias complementares. Comumente, é neste momento que se instaura o Incidente de Insanidade Mental: "se houver dúvida sobre a integridade mental do réu, o juiz ordenará de ofício ou a requerimento do Ministério Público, do defensor, do curador, do ascendente, descendente, irmão ou cônjuge do acusado, seja este submetido a exame médico-legal ${ }^{, 21}$.

Concluída esta fase de instrução, sendo o acusado considerado imputável ou semi-imputável ${ }^{22}$, e a Denúncia válida e pertinente, o juiz (singular) sentenciará a Pronúncia do réu, para que seja julgado pelo tribunal do júri.

\footnotetext{
${ }^{21}$ Conforme o Artigo 149 do Código de Processo Penal, comentado por Mirabete, J.F. , obra citada, pág. 210.

${ }^{22}$ Há imputabilidade quando o sujeito é inteiramente capaz de compreender a ilicitude de sua conduta e de conduzir-se de acordo com este entendimento. Excluem a imputabilidade, logo também a culpabilidade, a doença mental e o desenvolvimento mental incompleto ou retardado [artigo 26], a menoridade, por presumir-se incompleto o desenvolvimento mental [artigo 27] e a embriaguez fortuita completa [artigo 28, parág. $1^{\circ}$ ]. O imputável deve ser julgado e pode ser condenado a pena. O inimputável não pode ser apenado, e uma vez tendo praticado uma conduta ilícita presume-se sua periculosidade, impondo-se obrigatoriamente a medida de segurança de internação em hospital de custódia e tratamento psiquiátrico, se o crime praticado seria apenado com reclusão; ou de tratamento ambulatorial, se o crime praticado seria apenado com detenção. Quanto ao semi-imputável, vigora a partir de 1984 o sistema vicariante, pelo qual compete ao juiz arbitrar o cumprimento de pena ou de medida de segurança, sendo que neste último caso passará o sentenciado à condição de inimputável.
} 
Pronunciado, o réu será então submetido ao júri popular, na forma da lei. O julgamento se faz mediante as respostas ["sim" ou "não"] dadas por sete jurados aos quesitos formulados pelo juízo, versando, ítem por ítem, sobre a materialidade e autoria do crime, e sobre a culpabilidade do réu. As decisões dos jurados, obtidas pela maioria simples das sete respostas aos quesitos, devem referendar as provas obtidas nas investigações e perícias e também as conclusões que, mesmo sem possibilidade de provas cabais, conferem ao libelo-crime ${ }^{23}$ um corpo coerente.

Sérgio Adorno comenta as "opiniões ambíguas e paradoxais" de promotores públicos e magistrados quanto ao tribunal do júri, onde reconhecem um espaço de "distinção e prestígio social" ao mesmo tempo em que consideram os jurados "despreparados para a delicada e complexa função de julgar e punir (...). Daí a necessidade de se 'conduzir' com alguma tendenciosidade o curso dos trabalhos e procedimentos durante a sessão do júri, a fim de evitar que a injustiça se instalasse no Tribunal. Em outras palavras, manipuladores técnicos valiam-se de certa distorção nos procedimentos com vistas a assegurar a justiça". O autor pondera que, "legítimos ou não, esses argumentos acabam colocando a instituição do tribunal do júri sob suspeição” [Adorno, 1994. Pág.136].

Isto parece mesmo verdade, ao menos quanto à elaboração dos quesitos para o julgamento. Formulados com base no libelo-crime, que reproduz a Pronúncia que, por sua vez, fundamenta-se sobre a Denúncia e

\footnotetext{
${ }^{23}$ O libelo-crime é uma exposição articulada daquilo que se pretende provar contra um réu, apresentada [pelo Ministério Público] após a sentença de pronúncia, à qual deve conformar-se (Novo Dicionário Aurélio da Língua Portuguesa).
} 
esta sobre o Inquérito Policial, estes quesitos tendem a promover a validação soberana do júri não apenas dos resultados mais objetivos (provas, laudos, etc.), como também dos mais subjetivos, das investigações e conclusões do processo. Para ilustrar estas afirmações, pode-se tomar dois dos quesitos formulados para o julgamento do caso de Roberto, quanto a cada um dos homicídios:

$\mathbf{2}^{\circ}$ quesito - Tais lesões [descritas no laudo de exame necroscópico], por sua natureza e sede, foram a causa da morte da vítima? (materialidade acolhida por sete votos a zero).

$5^{\circ}$ quesito - $\mathrm{O}$ crime foi praticado por motivo torpe [afirmado no libelo-crime: tinha por escopo ficar com a herança da vítima]? (qualificadora reconhecida por cinco votos contra dois).

Note-se que o tema do segundo quesito é matéria incontroversa, plenamente verificada e atestada pelo exame necroscópico realizado por médicos legistas, e chega a parecer risível a necessidade de que sete pessoas do povo venham confirmar os resultados da perícia. Mas a força de validação que assim é conferida ao corpo de jurados quase obnubila o estratagema de lançar-lhe, no quinto quesito, uma conclusão não corroborada por qualquer prova, e ainda em flagrante contradição com outros elementos apurados e atestados no processo, como a ausência de premeditação. A decisão dos jurados, porém, é soberana e torna incontestável as afirmações acolhidas ${ }^{24}$.

\footnotetext{
${ }^{24}$ De acordo com a Constituição Federal, Artigo 5 - XXXVIII, c, os veredictos do júri são soberanos e não podem ser reformados pelo Tribunal de Justiça. Caso o juiz entenda que este veredicto é contrário às provas, pode apenas determinar um novo julgamento.
} 
Finalmente, com base nas decisões dos jurados, compete ao magistrado que presidiu o julgamento fixar a pena para o condenado, de acordo com os critérios legais.

Durante todo o processo, as atenções dos manipuladores técnicos concentram-se primariamente no autor (acusado) e no fato, e secundariamente na vítima. Sobre o autor, perscruta-se especialmente seus antecedentes criminais, sua personalidade, funcionamento mental, adequação aos padrões sociais, condições socioculturais e aspectos orgânicos supostamente ligados à conduta criminosa. Quanto ao fato, procura-se estabelecer os motivos que levaram o autor ao delito, os meios, modos e circunstâncias da conduta criminosa e seus resultados. Sobre a vítima, importa saber suas relações com o acusado e os efeitos sofridos por ela e por seus familiares em razão do crime. Apenas se a estratégia de defesa pauta-se por promover uma "inversão simbólica das posições de réu e vítima”, nas palavras de Sérgio Adorno ${ }^{25}$, passa-se a investigar sua vida pregressa criminal, social e moral.

A forma assumida pelo relato policial, pericial e jurídico da investigações e conclusões sobre o crime, até o desfecho do julgamento pelo júri, com a anexação de inúmeros documentos independentes entre si (autos, relatórios, boletins, laudos, etc.) e com a supressão do registro de boa parte das falas dos manipuladores técnicos que trabalharam no caso, contribui para que a leitura do processo judicial transmita uma tal

\footnotetext{
${ }^{25}$ Adorno, S. Obra citada, pág. 142. Refere-se o autor às vítimas dos chamados "crimes de paixão" e às "vítimas criminosas", que freqüentemente têm sua figura poluída pela estratégia de defesa do réu. Trata-se da estratégia de defesa mais recorrente nos casos estudados por
} 
impressão de objetividade, capaz de velar o longo trabalho de apuração ou de construção - da verdade sobre o crime e os envolvidos.

Mas, para que tal impressão não resista a um segundo olhar, bastará a lembrança de que este trabalho foi, forçosamente, efetuado por homens... pessoas que se defrontaram com a notícia de uma morte e que, em função de suas profissões, tinham o dever de olhar para ela, tocá-la, manipulá-la, registrá-la em todos os seus detalhes, contrariando todos os sentimentos aversivos que este ofício provoca nos homens; operacionalizando, no grau extremo possível, dentro de padrões de condutas técnicas e ritualizadas, todos os humanos sentimentos de fascínio e curiosidade; transpondo os abismos criados pelo ancestral tabu da morte...

Pode ser cômodo, para o comum dos homens, pensar que estas pessoas escolhem suas profissões em razão de idiossincrasias prévias, ou que as desenvolvem no exercício destas profissões, que as tornam imunes a estes sentimentos, ou que lhes conferem, até, possibilidade de genuína gratificação ao lidar com estas situações. Isto tudo pode ser, em parte, verdadeiro. Mas o alto índice de alcoolismo entre os funcionários dos Institutos Médico-Legais, para citar apenas um elemento de dúvida, deve bastar para sustentar a suspeita de que estas pessoas trabalham expostas a exigências emocionais acima do limite tolerável, mesmo para quem escolheu este trabalho e o executa a muito tempo.

Apenas por isto, já é razoável supor que os registros da morte pedra fundamental de toda a investigação posterior, bem como de todos os discursos que serão produzidos sobre o fato - estarão bem mais distorcidos pela subjetividade que os efetuou do que as instâncias sociais encarregadas de estabelecer a verdade, em seu desejo de pura objetividade e razão,

Mariza Corrêa em Morte em Família, citado; no caso de Roberto, tal estratégia não foi sequer esboçada. 
gostariam de admitir. E este efeito deformador não se esgota no momento do registro da morte. Ao contrário, a cada desdobramento de sua apuração e julgamento novas exigências, técnicas, éticas, emocionais, impõem-se aos profissionais envolvidos, além das confrontações com as opiniões, preconceitos, sentimentos, interesses, limitações, os mais diversos, partindo das mais diversas figuras e instituições sociais.

Gestada neste caldo, onde se mesclam as mais imponderáveis angústias, as mais irracionais defesas, as pressões mais difusas e poderosas, a verdade sobre um homicídio não poderia resultar menos humana. Tratarse-á sempre de uma interpretação, lábil, fugaz, contingente, parcial... jamais uma representação adequada, conforme ao acontecido. Neste sentido, um homicídio pode assemelhar-se a uma obra de arte que, no pensar de Merleau-Ponty, não se cumpre ao existir em si como coisa, mas quando "atinge o espectador, convidando-o a retomar o gesto que a

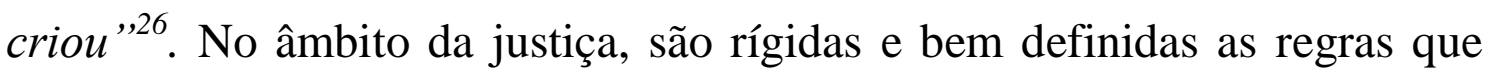
fazem cessar a produção destas interpretações, quando transitada em julgado a sentença. Mas isto não impede a contínua retomada interpretativa de um crime, em outras esferas. Retomadas que parecem tender tanto mais ao infinito quanto mais tenha o crime horrorizado seus espectadores, na época de sua ocorrência.

Este olhar humano que reconstrói o homicídio é, além de seletivo porque emocionado, também um olhar que impele à busca - que fica a exigir - a palavra definidora capaz de apaziguar os sentimentos. Em sua dissertação de mestrado, José Moura Gonçalves Filho comenta o relato da moradora de um bairro periférico em São Paulo, que conta como subia num

\footnotetext{
${ }^{26}$ Merleau-Ponty, M. A Linguagem Indireta e as Vozes do Silêncio. São Paulo, Abril Cultural, 1975 (os Pensadores), pág. 341.
} 
armário para espiar pela janela quando ouvia, vindos da rua, os sons da violência. Diz o pesquisador: "a necessidade de ver, angustiante, é o esforço para conter impulsos sem nome, é o pedido de nomes, pedido de significado - enquanto não vem a palavra, o homem é paralisado ou responde com violência à violência (...) apenas a palavra pode orientar na violência. E o exercício da palavra, seu desdobramento, só é possível fora de toda violência. A violência e a palavra, lembra Hannah Arendt, excluem-se mutuamente” [Gonçalves Filho, 1995. Pag. 106].

Esta afirmação, sempre verdadeira, o é tão mais quanto mais contundente e franca é a violência de que se trata. No extremo, a coação, a tortura, a exploração, a humilhação, o desrespeito, a miséria, e todas as formas de violência, enfim, suprimem a palavra autêntica de quem a sofre ou exerce. A vítima emudece frente ao terror, à dor ou à impotência; mas também seu algoz, enquanto sujeito falante, há de sucumbir diante da violência praticada: o patrão explorador recusa-se a conversar com seus empregados; o torturador alega estar cumprindo ordens de outrem; o espancador profere interjeições e palavras desconexas.

Penso, entretanto, que mesmo longe de toda violência contundente e franca, persistem ainda condições muito adversas ao pleno exercício da palavra, seu desdobramento autêntico e livre. Michel Foucault aponta que "em toda sociedade [grifo meu] a produção do discurso é ao mesmo tempo controlada, selecionada, organizada e redistribuída por certo número de procedimentos que tem por função conjurar seus poderes e perigos, dominar seu acontecimento aleatório, esquivar sua pesada e terrivel materialidade,27.

\footnotetext{
27 Ao longo da conferência, o autor apresenta-nos os procedimentos de controle, que visam I. Dominar os poderes do discurso: a interdição de temas, a segregação da loucura, a oposição verdadeiro- falso; II. Conjurar o acaso da aparição do discurso: a exegese, a identidade do autor, o regime de disciplinas; III. Qualificar (rarefazer) os sujeitos que falam: os rituais de
} 
São os vínculos da palavra com o desejo e o poder que traçam os limites e as características do discurso. A análise destes vínculos poderia, partindo de qualquer uma das realizações humanas, retroceder até os processos primitivos de simbolização e de aquisição e desenvolvimento da linguagem e do pensamento pelo bebê; deve-se lembrar que, em seus primórdios, símbolo, fala e pensamento estão a serviço do enfrentamento de frustrações e/ou da influência sobre o meio, especialmente sobre o comportamento de outrem, com o propósito de alcançar gratificações. De qualquer modo que os tomemos, sempre serão tentativas do indivíduo que visam controlar as condições, internas ou externas, de realização dos seus desejos. E se já em sua mais remota origem a linguagem dá-nos a conhecer seus vínculos com o desejo e o poder, o mesmo acontece com suas mais altas e elaboradas expressões, coisa da qual os embates político-ideológicos podem ser o mais ilustrativo exemplo mas nem de longe são o único. Atualmente, tão denunciadas foram suas tendenciosidades, que nem os mais ingênuos podem estar convictos da pretensa racionalidade e isenção mesmo dos discursos filosóficos e científicos.

Resultado infalível de um homicídio violento é uma generalizada e incoercível loquacidade social a respeito de seus motivos, detalhes e conseqüências. O burburinho instala-se nos arredores de sua ocorrência, mesmo que à boca miúda quando assim o exige a lei do silêncio. A "máquina tagarela da justiça", nas palavras de Peter e Favret, imediatamente põe-se a funcionar, produzindo seus boletins, relatórios, laudos, pareceres e sentenças. E tudo isto vai ampliar-se e reverberar na imprensa escrita e falada, quiçá ainda nas narrativas literárias. Mas toda

qualificacão dos falantes e dos ouvintes e os rituais de distribuição dos discursos [Foucault, 1996]. 
esta verborragia fala também, senão mais, da sociedade na qual ocorreu o crime.

Sérgio Adorno informa-nos, no artigo Violência Urbana, Justiça Criminal e Organização Social do Crime [Adorno, 1991], como o exame das práticas de produção da verdade jurídica pode revelar móveis extralegais, subjetivos, que intervêm nas decisões judiciárias. O próprio autor resume, em artigo mais recente, as conclusões daquele trabalho. Embora o trecho seja um pouco longo, sua clareza insuperável exige sua citação literal:

“(...) Naquele ensaio, observou-se que o desfecho processual resultava da conexão de duas ordens de motivação da conduta institucional: por um lado, motivações de ordem burocrática, presas aos códigos e aos procedimentos formais e que se atinham às posições previamente demarcadas de vítimas, agressores ou acusadores. Sob essa ótica, o objeto do litígio gravitava em torno do crime, das informações processuais, dos documentos anexados aos autos, do estrito cumprimento dos dispositivos legais. Deficiências certamente poderiam ser detectadas, porém se deviam às imprecisões técnicas e às divergências nas interpretações dos estatutos legais. Os dilemas e impasses estavam, por conseguinte, a reclamar progressiva racionalização técnica e administrativa, expressa na necessidade de uma polícia judiciária tecnicamente eficiente, de reforma na legislação penal e de serviços judiciais mais céleres.

Quando, porém, dirigiu-se o foco de atenção para os móveis subjetivos, o interesse processual se deslocou do âmbito do crime para o do comportamento criminoso. 
Nesse deslocamento, iluminou-se objeto distinto: o mundo dos homens com seus comportamentos, seus desejos, suas virtudes e vícios, suas grandezas e fraquezas, os pequenos dramas da vida cotidiana, a violência endêmica entre iguais, a pobreza de direitos que caracteriza a vida dos protagonistas, alguns dos quais incidentalmente convertidos em agressores, enfim a trama que enreda homens comuns e agentes da ordem em uma esquizofrênica busca de obediência a modelos de comportamento considerados dignos, justos, normais, naturais, universais e desejáveis. Sob esse prisma, os embates do tribunal concentravam-se menos na proteção da vida enquanto um dos valores capitais de nossa cultura ocidental, porém gravitavam em torno dos dilemas entre moralidade privada e moralidade pública, cujo desfecho podia convergir arbitrariamente para a condenação ou absolvição. Aqui, não se pode falar rigorosamente em deficiências técnicas ou administrativas, todavia na maior ou menor sagacidade dos acusadores ou defensores em explorar espaços de avanço ou recuo, em surpreender o adversário em suas contradições $e$ paradoxos, em poluir ou heroificar personagens. Nesse terreno, estavam gestadas as condições para promover a injustiça. ”[Adorno, 1994, págs. 135/6. Grifos meus].

Para admitir que assim seja, se as conclusões do pesquisador não bastarem, novamente deveria ser suficiente a lembrança de que a justiça é obra humana. E se em seus discursos, tão minuciosamente regrados, vêm imiscuir-se os valores, modelos, ideais, disputas e desigualdades sociais, quando pretendem apenas patentear cegamente as constatações sobre fatos 
e indivíduos - réu, vítima, testemunhas - é porque interagem no processo indivíduos, sim, detentores de ânimo próprio, mas que se forjaram imersos num contexto sócio-cultural; e isto inclui, enfatizo, os manipuladores técnicos que falam acerca do caso. Pode-se afirmar, sem receios, que isto é verdadeiro para quaisquer outros discursos produzidos sobre um homicídio - como, de resto, sobre qualquer ação humana. Tratar-se-ão sempre, como já ficou dito, de interpretações oferecidas pela coletividade social para um ato que em sua presença foi praticado.

Importa observar que, ao reverso, o homicida também é partícipe da construção coletiva desta interpretação e, de certa forma, avaliza-a, na medida em que esteve sempre imbuído da mesma cultura que irá julgá-lo e portanto podia saber de antemão os julgamentos aos quais era passível seu crime, não apenas enquanto ato proibido - matar alguém - mas também quanto às particularidades de sua execução. Por exemplo, ao acrescentar um tom de crueldade ou aviltamento contra a vítima, o homicida sabe que estará angariando uma dose maior de repulsa social. Insinua-se aqui um paradoxo $^{28}$ : ainda na prática do ato anti-social por excelência, o homem permanece um ser social; e se é verdade que muitas vezes seu crime afronta os cânones da civilidade, também o é que mesmo o mais brutal deles deixa vestígios de haver trepidado ante as interdições culturais, e de ter valido-se de seus modelos, técnicas, códigos e símbolos.

Encontra-se um exemplo disto no caso de Francisco de Assis Pereira, cujos crimes estarreceram a humanidade: ele disse em seus depoimentos à polícia que, sentindo fome e desejando comer o corpo de uma moça que acabara de violentar, apiedou-se dela e matou-a antes de

\footnotetext{
${ }^{28}$ Melhor seria dizer um falso paradoxo, como pretendem demonstrar as análises desenvolvidas neste trabalho.
} 
começar a mordê-la ${ }^{29}$, e que jamais chegou a ingerir a carne de suas vítimas, embora o atormentasse a idéia de que, mais cedo ou mais tarde, o faria. Aqui, não importa saber se estes depoimentos correspondem ou não à verdade, mas tão somente reconhecer a preocupação do autor, tido como um maníaco, em afirmar diante da sociedade haver refreado seus impulsos que atentavam contra um de seus maiores, senão o maior, tabus.

O assassino feroz, atuando sem limites seus desejos cruéis, não é mais que uma ficção. Homens, e não feras, cometem homicídios; e homens estão, inexoravelmente, sob a influência das leis culturais. Isto permanece válido mesmo quando o homicida procura ocultar seu crime, pois que o faz levando em consideração precisamente o julgamento (em sentido amplo) esperado da parte de seus pares sociais. Que outro motivo levaria os seqüestradores e homicidas do menino Yves a ocultar seu corpo sob o berço de uma criança, e não noutra parte da casa, senão a idéia de que a ninguém ocorreria procurar ali, pois que em nossa cultura a morte não se associa ao berço, símbolo do nascimento e da vida?

Também quando falta em absoluto a premeditação do ato homicida, amiúde ainda se pode reconhecer nele traços de um código compartilhado entre seu autor e seus sócios culturais. Assombra-nos que o parricida não raro decepe a cabeça de sua vítima [conforme Palomba, 1996, à página 202] e, no entanto, a decapitação do deposto é, historicamente, o símbolo mais claro da insurreição, da qual o parricídio é protótipo. Em acréscimo, deve-se notar que quando se busca depurar o papel da vontade do indivíduo criminoso na culpabilidade de sua ação, como se faz no

\footnotetext{
${ }^{29}$ Segundo reportagem sobre o depoimento à polícia, publicada no jornal Folha de São Paulo, edição de 13 de agosto de 1998, caderno 3, página 2 [Acusado confessa ter matado rápido vendedora e é indiciado].
} 
Direito moderno, o que sai enfatizado é na verdade o papel da cultura na formação desta vontade e é por isto que na doutrina da responsabilidade subjetiva aos silvícolas, aos jovens e aos alienados não se pode imputar culpa. De todo este longo e controvertido capítulo do Direito Penal resta dito que pode ser inculpado, e portanto punido, o homem que, sendo plenamente aculturado, é capaz de conhecer a lei, de compreender o caráter ilícito de uma dada conduta e de conduzir-se segundo esta compreensão e, estando em situação na qual pudesse agir legalmente, ainda assim deseja e escolhe praticar a conduta ilícita. Inadvertidamente talvez, os legisladores, juristas e médicos estão, no cuidado com que defendem o princípio da responsabilidade subjetiva e as condições para sua atribuição ao réu, reconhecendo a intersecção entre fatores individuais e coletivos que configuram esta responsabilidade.

Essas ponderações fazem-me acreditar que, na interpretação, ou seja, na construção da verdade sobre um homicídio, há uma colusão, inconsciente com certeza, entre seu autor e os demais membros da sociedade que o testemunhou. Estou, então, afirmando que a verdade assim construída não é da ordem de uma representação fidedigna dos fatos, mas de interpretações coletivas que não são nem estritamente racionais, nem tampouco caprichosas, como não o são os motivos e modos pelos quais os homicídios consumam-se. Antes, umas e outros seguem padrões estreitamente vinculados ao momento sócio-histórico e ao contexto cultural de suas ocorrências, que são as unidades macroscópicas de análise, respectivamente, das disputas de poder e das figurações do desejo ${ }^{30}$.

\footnotetext{
${ }^{30}$ Michel Foucault chega a afirmar, para o caso de Pierre Rivière, que seu "campo histórico foi menos a marca ou o conteúdo explicativo que a condição de possibilidade [daquele] assassinato-memorial" [grifo meu]. Talvez uma análise suficientemente aplicada de assassinatos contemporâneos possa demonstrar para esta afirmação uma validade muito mais ampla do que a pretendida por seu autor. [Foucault, M., 1977. Pág. 220].
} 
A repercussão na imprensa parece fornecer o índice mais claro da amplitude do estarrecimento social catalisado por um homicídio - seja por retratá-lo ou por fomentá-lo - especialmente quando aparece marcada pela perplexidade e repugnância. Estes sentimentos parecem estar indefectivelmente presentes em todos os modos de reação social a certos crimes. É revelador do sentimento de perplexidade a negação ao crime de um sentido apreensível pela comunidade, que manifesta-se pelo insistente questionamento sobre a causa ou razão do crime, traduzido nas repetidas consultas a figuras sociais representativas de determinados campos de saber: o policial, o jurista, o psiquiatra, o psicólogo, o vidente, o religioso; e se multiplica nas entrevistas com pessoas relacionadas aos envolvidos, como parentes, vizinhos, conhecidos antigos.

Parece haver, também, uma tentativa de classificação, que é um modo básico de compreender, quando a imprensa, principalmente a escrita, relembra episódios similares do passado. Forma-se, assim, uma verdadeira galeria de homicidas exemplares, sempre pronta a atestar que o caso atual não é único. A revista Época, para ilustrar a notícia da prisão do colombiano Luís Alfredo Garavito Cubillos, que confessou o assassinato de 140 meninos, estampa no rodapé da página, sob o título "galeria dos assassinos", breves históricos sobre Pedro Alonso Lopes, Henry Lee Lucas, Bruno Ludke e Andrei Chikatilo, responsáveis pelo homicídio de, respectivamente, 300 mulheres, 200 pessoas, 80 mulheres e 53 crianças e adolescentes $^{31}$. Na mesma edição, para ilustrar o caso de Mateus da Costa Meira, que abriu fogo contra a platéia de um cinema em São Paulo, matando três pessoas, a revista utiliza-se de um quadro sobre os random shootings americanos, com destaque para o caso de Byran Uyesugi, que

\footnotetext{
${ }^{31}$ Revista Época, 77, de 8 de novembro de 1999 (Ed. Globo). Página 147.
} 
matou sete pessoas num escritório, poucos dias antes ${ }^{32}$. O jornal Folha de São Paulo utilizou Roberto como ilustração para dois outros crimes em família, em 24NOV89 e 26MAI90, e para o caso de um rapaz que matou a família vizinha, em 30MAR90.

Quanto ao sentimento de repugnância, isto transparece nos apelidos dados ao homicida e nos adjetivos usados para descrevê-lo e aos seus crimes. As páginas policiais dos jornais diários trazem nas manchetes toda sorte de monstros e maníacos, aos quais atribui-se, sem muito critério, frieza, indiferença, brutalidade. Seus crimes são descritos como hediondos, brutais, bárbaros, desumanos, animalescos. A forma assumida por estes relatos repudia a pessoa do homicida até o extremo de exclui-lo dos limites da categoria humana. Sobre Francisco de Assis Pereira, o maníaco do parque, o jornal Folha de São Paulo publicou na seção Opinião um texto no qual Carlos Heitor Cony chega a argumentar tratar-se de uma besta nascida em meio à sociedade ${ }^{33}$. Roberto recebeu, do jornal Notícias Populares, o epíteto de o monstro da zona sul, e a Folha de São Paulo chamou-o $o$ matador.

\footnotetext{
${ }^{32}$ Idem, página 30.

${ }^{33}$ Folha de São Paulo, edição de 10 de agosto de 1998, caderno 1, página 2 ( $A$ Besta Humana).
} 
Capítulo 3:

Roberto e sua família... 


\section{Roberto $^{34}$ e sua família... ${ }^{35}$}

\section{O fantasma da morte paira sobre a família ${ }^{36}$.}

Roberto nasceu na Venezuela, mas ainda bem pequeno passou a residir no Brasil. Seu pai, Mário, nascera em Portugal; sua mãe, Karin, na Polônia. Seus irmãos, Paulo, Cristina e André, mais jovens que ele, nasceram todos em São Paulo.

Sobre os pais de Mário não há outras informações, além de que eram portugueses e de que sua mãe vivia na Venezuela. Apenas um de seus irmãos, Raul (empresário), morava no Brasil. Sobre a mãe de Karin, polonesa, diz-se que havia sido neurotizada pela $2^{\text {a }}$ Grande Guerra; uma amiga diz que a própria Karin guardava fortes impressões deste período, quando até fome passou. Sua mãe e um irmão, Ricardo (empresário), viviam no Brasil.

\footnotetext{
${ }^{34}$ Estive muitas vezes tentada a procurar Roberto, mas desisti sempre, impedida basicamente pelo medo de que ele correspondesse à imagem que dele restou nos discursos que li a seu respeito, mas principalmente, medo de que ele não correspondesse. Neste caso, pensava, minha visita reabriria as feridas que aqueles discursos então lhe provocaram. Talvez soasse mais elegante dizer que não o procurei para não contaminar minha análise do caso, mas não foi por isto. Foi por sentimentos amedrontadores, diante dos quais me acovardei.
}

\footnotetext{
${ }^{35}$ A idéia neste tópico é traçar o quadro sócio-econômico e cultural daquela família. Eu e o leitor temos que aceitar a ausência de algumas informações; o processo penal e as reportagens sobre o caso não trataram de traçar este quadro.

${ }^{36}$ Frase de Massimo Canevacci, comentando as relações naturais da família com a morte.
} 
$\mathrm{Na}$ época do crime, Mário tinha 46 anos de idade, e trabalhava como desenhista projetista numa indústria automobilística multinacional. Karin tinha 42 anos, e trabalhava como operadora de telex. Tempos antes, ela havia tentado um negócio próprio ( confecção de produtos naturais comestíveis, dizem os autos), em sociedade com uma vizinha. O casal preocupava-se com a permanente ameaça de demissão de Mário; apenas ele, em seu departamento, não era engenheiro ${ }^{37}$. Karin planejava abrir, junto com Roberto, uma doceria/sorveteria. Há notícias de que meses antes do crime seu irmão, Ricardo, havia proposto à Mário que investisse em sua empresa certa quantia de dinheiro, tornando-se seu sócio, mas Karin manifestou-se contrária a esta sociedade. Além da casa onde morava a família, o casal possuía uma casa no litoral, um terreno e dois automóveis.

Roberto já havia trabalhado como office-boy e como motorista, e estava submetendo-se ao exame de seleção para admissão num grande banco. Cursava a $7^{\mathrm{a}}$ série do ensino supletivo do $1^{\circ}$ grau; antes, havia iniciado e desistido de um curso técnico de desenho mecânico. Na data do crime, contava 18 anos de idade. Cerca de 6 anos depois, em entrevista ao jornal Folha de São Paulo, disse haver um equívoco em seu registro de nascimento e que seria, então, dois anos mais velho. Não fica claro se Cristina, 16 anos, estudava nesta época e não há referência a que tenha

\footnotetext{
${ }^{37}$ A posição de Mário em seu emprego parece-me provocar importantes reflexos sobre a situação familiar no momento do crime, e isto aparecerá afirmado sucintamente em meu texto, adiante. Para evitar alongar-me demasiado na consideração desta circunstância, sugiro a leitura de um estudo de Luc Boltanski, Os executivos autodidatas, que aborda as experiências de um grupo profissional marcado pela ambigüidade de sua posição no quadro empresarial, relacionando-a com a ambigüidade de sua posição na estrutura social [Boltanski, 1984].
} 
estado empregada alguma vez. Paulo, 17 anos, e André, 8 anos, apenas estudavam, regularmente.

Os vizinhos são unânimes em declarar que todos na família eram pessoas polidas, cordiais. Mário e Karin passavam fora a maior parte do tempo, trabalhando. Eram vistos como pessoas reservadas no trato com os outros, inclusive com os filhos; várias testemunhas referiram certa frieza e distanciamento, atribuindo este caráter ao fato de serem europeus. Especialmente Karin era vista como pessoa fria, cujo comportamento despertava às vezes a antipatia das pessoas. Alguns vizinhos e mesmo parentes mais distantes dizem que as pessoas daquela família pouco se reuniam, pois cada um tinha seus próprios afazeres. Não obstante, todas as testemunhas disseram que se davam bem, e que apenas haviam as discussões normais de todas as famílias.

Uma vizinha conta que Mário queixou-se, tempos antes, de que o filho Paulo não aceitava mais sair em sua companhia, e estaria tendo desavenças freqüentes com Roberto, porque este dava-lhe ordens. Paulo é sempre descrito como estudioso, e quase não saía de casa. Lia livros de guerra e jogava xadrez.

Cristina namorava um rapaz, contrariando a vontade dos pais. Dava-se mal especialmente com a mãe. Em razão destes atritos, havia deixado a casa por volta do mês de outubro/84, sem informar à família seu paradeiro. Hospedou-se primeiro na casa do namorado; depois com uma amiga que não depôs no processo e, finalmente, na casa de uma antiga vizinha, que agora morava noutro município. Esta senhora, amiga de sua mãe, manteve Karin informada sobre a filha e promoveu sua volta à casa depois do natal. Durante o período em que Cristina esteve ausente, Karin comentou com algumas pessoas, amigos e parentes, que Roberto vinha lhe 
dando grande apoio nesta situação difícil, e era o filho com quem melhor relacionava-se.

André era tido como garoto normal, um pouco retraído. Tinha amigos na vizinhança, entre os meninos de sua idade. Várias testemunhas confirmam a declarada predileção de Roberto por este irmão, com quem era especialmente atencioso.

Roberto é referido por várias testemunhas como dócil, cordial, prestativo, alegre. Vizinhos, amigos e parentes $^{38}$ afirmam que se relacionava bem com todos de sua família, especialmente com sua mãe e com André. Também afirmam tratar-se de rapaz responsável e ordeiro, até um pouco moralista, que tinha apenas boas amizades, não tinha qualquer vício nem envolvia-se em brigas. Ao contrário, era pacato e apaziguava as desavenças que surgiam entre os meninos da vizinhança. Uma moça ${ }^{39}$ que residiu na casa por cerca de 8 meses, afirma que Roberto ajudava a mãe em suas tarefas domésticas, e fornecia-lhe dinheiro quando estava "apertada"; também que Roberto, ao sair pela manhã, "se despedia do pai com um beijo". Tivera algumas poucas namoradas, e havia alguns meses que namorava Judite, com o consentimento dos pais dela; os depoimentos de ambos deixam claro que se tratava de um namoro sério. O pai de uma exnamorada enfatizou seu bom comportamento e suas qualidades, como também o fez um ex-patrão. Gostava de ouvir música, e este era seu principal passatempo.

\footnotetext{
${ }^{38}$ A única exceção a esta opinião generalizada sobre Roberto provem de seu tio Raul, como será apontado adiante. Este dirá que Roberto, um ano antes (com 17 anos, portanto), tornouse agressivo e desobediente, querendo levar uma vida independente.

${ }^{39}$ Trata-se de Júlia, uma ex-namorada de Roberto. Karin convidara esta moça para residir em sua casa, após o fim do namoro. Júlia deixou a casa meses antes, mas ainda na quinta-feira anterior ao crime, em visita, lá pernoitara.
} 
No processo, as informações reunidas no quadro que acabo de traçar aparecem (e permanecem) dispersas nas falas das várias testemunhas, em diferentes momentos; entretanto, a situação sócio-econômica da família não é jamais delineada com clareza, nem considerada como elemento condicionante das relações e dos eventuais conflitos que antecederam o crime. Quanto a isto, verifica-se aqui o mesmo efeito apontado por Mariza Corrêa: No processo é produzida uma mediação que achata a espessura inicial dos acontecimentos e despolitiza as relações entre as pessoas no mundo, ao ignorar o seu contexto básico (...) [Obra citada, pág. 300].

Este efeito encontra-se visível já em toda a sua clareza na tese da acusação apresentada na Denúncia, em 18JAN85, que segue sendo reafirmada até o libelo e é referendada, enfim, no julgamento. Em essência, o quadro traçado pelo promotor público, contornando os testemunhos que acabo de apresentar, retrata tão somente a quietude harmoniosa do sono da família, bruscamente rompida pelo crime de Roberto.

Todavia, aquelas falas permitem entrever um contexto bem mais espêsso, bem mais ambígüo, ambivalente: Judite, por exemplo, afirma ter presenciado “quando o réu [Roberto] e sua mãe 'faziam planos' para montar uma doceria, sendo que eu me limitaria a 'ajudar'. Entre eu e o réu havia plano de casamento, mas para o futuro, sem nada concreto para o momento"; também conta que no mês de novembro desentendera-se com seu próprio pai e dirigira-se à casa de Roberto levando todos os seus pertences; Karin e Mário intercederam junto a Roberto e aos pais de Judite, promovendo seu retorno à sua própria casa poucos dias depois. Durante o período que permaneceu na casa de Roberto, dormia no quarto de Cristina, que estava ausente (trata-se do período em que esteve morando fora), em companhia de André, o caçula. Considerando-se que Roberto e Judite haviam aberto uma conta bancária conjunta, tratavam com seriedade o 
namoro, mantinham relacionamento sexual e sonhavam com o casamento, é evidente que os planos de Karin, e a atitude dela e de Mário diante da chegada de Judite em sua casa, não se coadunavam inteiramente com os desejos e planos de Roberto e de Judite. Da mesma maneira os planos de Roberto, de obter emprego no litoral, contrariavam os projetos de Karin, de tê-lo como sócio numa doceria ${ }^{40}$.

Outros conflitos se desenham a partir dos depoimentos prestados pelo tio paterno, Raul, em seu primeiro depoimento [30JAN85], ainda durante o Inquérito Policial: afirma que Roberto desde um ano antes passara a ser 'um problema para os pais, pois abandonou a escola e passou a ter uma vida independente, não dando satisfações do que fazia e chegando altas horas da noite; QUE, Roberto, por esta época, passou a não mais respeitar os pais, chegando, às vezes a gritar com a mãe e quase chegar à agressão, isso na presença do depoente”. Mas também que "não sabe apontar a causa que levou Roberto a cometer tal gesto" [refere-se aos homicídios], e que era "um rapaz normal". Contrastadas com as considerações feitas acima, estas notícias corroboram a idéia de que a independência pretendida por Roberto instalava um conflito entre ele e seus pais, notadamente entre ele e Karin.

Raul prossegue em seu depoimento, informando espontaneamente sobre um pedido de Ricardo, feito dias antes, de que consentisse na liberação de importância devida à Mário pela empresa na qual trabalhava, para ser utilizada na defesa de Roberto; e em seguida sobre a proposta de sociedade feita por Ricardo à Mário, meses antes do crime.

\footnotetext{
${ }^{40}$ Após entrevistar Judite, o jornal Notícias Populares de 14JAN85, resume os planos do casal: Roberto [quando foi preso] tinha em seu poder, além de uma sacola cheia de revistas, uma aliança, que comprara recentemente. Ele e Judite pretendiam casar-se em breve. O casal tinha
} 
Elenca as propriedades de Mário, e informa o valor do capital passivo da empresa de Ricardo. No contexto deste depoimento, torna-se evidente uma animosidade prévia entre Raul e Ricardo, envolvendo questões patrimoniais, acirrada depois da morte do casal em razão da disputa pela herança. Dias antes, Ricardo contratara o advogado de defesa para Roberto e reinvindicara sua tutela, com a finalidade necessária de reger a pessoa de seu sobrinho, assisti-lo, e ainda, administrar-lhe os bens. Em resposta, Raul contrata um advogado para funcionar no inventário, e para promover a competente ação de exclusão de Roberto da herança.

Lidas por este prisma, as declarações de Roberto e das outras pessoas ouvidas no processo mostram-no tentando traçar um caminho para a independência financeira, apoiado nos recursos familiares: pensa em abrir uma loja de discos, em sociedade com a mãe, ou ainda uma doceria. Candidata-se a um emprego bancário e acalenta esperanças de, quando admitido, ser transferido para a cidade litorânea onde a família tem uma casa. Mostram-no, também, descrente de encontrar garantias de ser bemsucedido seguindo os passos do pai: abandonou o curso técnico de desenho mecânico, e seguia hesitante o curso supletivo do $1^{\circ}$ grau.

É preciso notar que esta atitude refletia a insegurança experimentada por seus pais em relação ao emprego de Mário, e a busca de Karin por alternativas para estabelecer-se por conta própria - o casal parecia estar, também, buscando formas de garantir a estabilidade financeira que percebiam estar ameaçada. Neste contexto, Karin contava com o apoio de Roberto para o estabelecimento da doceria.

idéia de morar na cidade [litorânea, onde ficava a casa de praia da família], onde Roberto trabalharia numa agência bancária. 
A particular inserção social desta família, suas possibilidades de emprego e negócios, de consumo e de relações sociais, estão na base dos conflitos que surgiram em seu seio por ocasião da adolescência dos filhos. Prova disto é que o mesmo conflito insinuava-se nas famílias próximas, de nível sócio-econômico equivalente: Cristina deixa sua casa para ir morar na casa do namorado, mas ali não pode permanecer muito tempo; da mesma maneira Judite dirige-se à casa de Roberto, com o mesmo resultado. Entretanto, Júlia é convidada por Karin a residir na casa e aí permanece por oito meses; porém, isto ocorre quando já não é mais namorada de Roberto e este, inclusive, já está namorando outra moça. Tudo bem pesado, parece claro que a atitude da família de Roberto, de promover a volta de Judite à sua própria casa era um veto a que o namoro entre os dois evoluísse para a vida conjugal.

Diante da pergunta do psiquiatra forense, meses depois do crime, sobre seu relacionamento com pessoas do sexo oposto, Roberto contará o episódio ${ }^{41}$ : "certa vez ela [Judite] fugiu de casa e foi morar na minha por, aproximadamente, 1 semana, isso por causa que aconteceu a maior briga lá dentro da casa dela. O pai dela ameaçou o irmão com uma faca e acabou brigando com o irmão mais velho. Aí a Judite trancou a porta para o pai não pegar a arma e, na sequência, ela fugiu de casa e foi morar na minha. $O$ irmão dela também foi embora de casa. O pai da Judite, nessa época, disse que ela não ia receber herança, segundo ela me frizou. Aí, uma semana depois de ela estar lá em casa, o pai foi buscá-la. Ele chegou na porta de casa e deu uns tiros de 7.65 para o alto, para por medo na gente. Nós até guardamos os cartuchos de lembrança”.

\footnotetext{
${ }^{41}$ Transcrevo o relato feito pelo perito, no laudo psiquiátrico. No laudo, o trecho aparece entre aspas, mas não há informação sobre como foi feito o registro; provavelmente de memória, como diz o perito que fez em outros momentos.
} 
Note-se, porém, que diante do crime de Roberto, estes conflitos perderão qualquer interesse para policiais, juristas, jornalistas, psiquiatras; ninguém faz referência ao episódio narrado, nem se o investiga. Como deixei dito na Introdução [pág. 43 e seguintes], não é apropriado abordar o conflito de gerações ali onde ele acontece, em meio a uma família real, concretamente inserida na realidade sócio-econômica.

Estes conflitos que acabo de resgatar dos autos, longe de terem sido investigados e articulados com o crime, foram sistematicamente desconsiderados, tanto durante os interrogatórios como na construção das argumentações jurídicas, como resultado de duas ordens de procedimentos: uma delas, a atenção seletiva com que policiais e juristas conduzem a inquirição das testemunhas e do próprio Roberto; outra, a seleção dos falantes, em cada uma das esferas discursivas, operada ao longo do desenrolar dos acontecimentos posteriores ao crime. Posto que as perguntas dirigidas pelas autoridades ao interrogando ou depoente não ficam registradas, a orientação que imprimem aos depoimentos não pode ser inequivocamente apontada nos autos.

Não obstante, o conteúdo desta orientação torna-se perfeitamente detectável quando se considera simultaneamente ambas as ordens de procedimentos, apontadas: vê-se nos interrogatórios e depoimentos registrados, o progressivo afastamento dos detalhes mais concretos sobre a vida das pessoas em direção a um quadro menos nítido de suas relações e de suas ocupações. Vê-se, ainda, a exclusão do campo discursivo das falas que desviam desta orientação, delineada desde antes, mas que adquire a mais absoluta clareza nos autos da denúncia. 
$\mathrm{Na}$ denúncia, apenas um breve período contextualiza os homicídios: referindo-se ao momento em que Roberto chegou em casa, na noite do crime, o promotor diz que deparando com sua genitora, na sala de visitas, esta o repreendeu pelo adiantado da hora, repreensão, diga-se, normal, natural, própria de quem se interessava pela educação e formação do filho. Após este fato, a mãe-vítima recolheu-se ao dormitório do casal [Roberto ficou na sala e ligou] o rádio com o som elevado, perturbando o descanso de seus familiares. A genitora percebendo aquela situação desceu, novamente, sendo que, mais uma vez, após chamar a atenção do filho, desligou o aparelho de som, retornando aos seus aposentos. Ressalte-se aqui, que a nova reprimenda foi também normal e verbal, buscando tão só, demonstrar a insatisfação provocada pelo acusado. Ora, esta maneira de contextualizar o crime, em verdade, descontextualiza-o, porque aparta as condutas recíprocas entre Roberto e Karin do embate que ambos travavam em direção da autonomia.

Neste embate, inclusive por razões de ordem social mais $\operatorname{amplas}^{42}$, mãe e filho revezavam-se como aliado e como oponente um do outro, em cada momento. Destacados daí, torna-se impossível recuperar o significado do comportamento de Roberto, de chegar tarde em casa e de ligar o som em volume alto depois de ter sido repreendido, e também o significado da repreensão feita por Karin; destacado de seu contexto, tornase impossível recuperar o significado do crime de Roberto; mais que isto, torna-se inadmissível qualquer tentativa de compreendê-lo. Aqui não

\footnotetext{
${ }^{42}$ Por exemplo, a ameaça de desemprego que pairava sobre Mário poderia ser correlacionada com o modelo econômico brasileiro, e este com o contexto econômico internacional.

Evidentemente, uma tal análise ultrapassaria os limites deste trabalho, mas é importante assinalar a presença destes entrecruzamentos entre a vida social e a vida familiar.
} 
couberam as estratégias de acusação e de defesa, apontadas por Mariza Corrêa nos de casos de morte em família que envolviam conflitos de gênero ${ }^{43}$.

O resultado da descontextualização operada no processo de Roberto é um quadro superficial, que retrata uma família idealizada, harmoniosa, perfeitamente inserida numa sociedade perene e acolhedora. Todas as causas para o conflito patenteado pelos homicídios vão alojar-se, assim, na pessoa de Roberto; apenas a sua conduta, mais especificamente a sua conduta homicida, será esquadrinhada. A tese psiquiátrica, de que Roberto cometeu os homicídios porque era portador de epilepsia condutopática, aparece como forma subsidiária da tese jurídica da acusação. Não há propriamente uma tese de defesa: em suas argumentações, o advogado apenas busca ampliar as consequiências penais da doença diagnosticada em Roberto, clamando por sua inimputabilidade.

Houveram, porém, tentativas da sociedade no sentido de aclarar o contexto familiar conflituoso que antecedeu os homicídios, e também uma tentativa de formular uma defesa que considerasse este contexto na explicação do crime, sem negar a responsabilidade de Roberto na prática dos homicídios. Entretanto, a cronologia do perecimento destas tentativas, feita no capítulo $O$ Estado contra Roberto..., deve ser precedida da história do crime.

\footnotetext{
${ }^{43}$ Naqueles casos, promotores e advogados esmiuçavam a vida privada de homicidas e vítimas em busca dos sinais de sua adequação ou inadequação aos papéis socialmente prescritos para cada um deles, e remetiam o conflito desencadeador do homicídio para o desempenho destes papéis, da parte de cada um dos cônjuges, ancorando ai suas respectivas argumentações sobre a "injustiça" ou a "justiça" da violência cometida pelo homicida.
} 
Capítulo 4:

Roberto, o patri-matri-fratricida... 


\section{Roberto, o matri-patri-fratricida...}

São muitas vezes coisas bem insignificantes que causam a nossa perda definitiva e irremediável.

[I. S. Turguêniev]

Impossível contar o crime de Roberto; posso apenas contar o que li nas peças policiais, jurídicas, psiquiátricas e jornalísticas que antes o fizeram. Um homicídio, como fato acontecido, perde-se irremediavelmente ao primeiro olhar humano sobre ele e, precisamente no mesmo instante, passa a restar como reconstrução coletiva, sempre inacabada, a partir das interpretações que lhe são dadas. Compete-me, então, uma escolha: qual versão apresentar primeiro ao leitor, para poder prosseguir minha dissertação? Escolho apresentar o primeiro registro da versão de Roberto para os fatos, constante do Auto de Prisão em Flagrante, lavrado cerca de 24 horas após os homicídios. Não me iludo, porém: minha escolha é o exercício do meu poder sobre minha escrita; não é remédio para o irremediável. O registro policial não esteve isento da interpretação do delegado que o presidiu e do escrivão que o datilografou; o próprio Roberto havia oferecido um primeiro relato horas antes, não registrado, e passara o dia conversando com os policiais responsáveis por sua prisão; havia também sofrido o assédio de repórteres, mantido contato com parentes e amigos e sido ameaçado de linchamento por populares, defronte a casa onde morava e onde ocorreram os homicídios. Também não esteve isento do corte operado pela própria circunstância em que o relato foi tomado e registrado: naquele momento, interessava apurar o contexto imediato do crime: as horas que o antecederam; a movimentação de Roberto no interior da casa durante a execução dos homicídios e depois, no abandono dos 
corpos e na faxina; as pessoas que poderiam confirmar ou infirmar sua versão dos fatos.

Roberto informou que o dia anterior transcorreu normalmente, e no fim da tarde saiu de sua casa para visitar a namorada, Judite. Foram, então, para a casa de uma tia dela onde reuniram-se outros jovens, primos e irmãos de Judite. A tia preparou lanches para todos, e passaram a noite jogando vídeo game e conversando; a reunião foi absolutamente tranqüila, e não houve qualquer incidente. Também não houve qualquer consumo de substâncias psicoativas, inclusive álcool; todos ingeriram apenas o refresco de laranja que a tia havia preparado. Retornou à sua casa na madrugada, por volta de 1 hora, levado de carro por um dos irmãos de Judite, Orlando, que o deixou no portão. Roberto acreditava que sua família viajaria nesta madrugada para a casa de praia que possuíam e, vendo as luzes apagadas, imaginou que já haviam partido. Entretanto, encontrou a mãe na sala, assistindo televisão, enquanto os demais dormiam em seus quartos, no pavimento superior. Deste ponto em diante, parece-me preferível copiar a escrita do Auto: "QUE, sua mãe então desligou a televisão e passou a chamar a atenção do interrogando [Roberto], dizendo que o mesmo estava chegando tarde e que ele era um vagabundo que nada fazia; que, essa reprimenda da mãe 'tocou bastante' o interrogando, mas que o mesmo nada respondeu; QUE, a mãe então subiu para o andar superior e o interrogando [trocou de roupa e] deitou-se no sofá e ligou o rádio do aparelho de som, e instantes depois sua mãe desceu novamente as escadas, dizendo ao interrogando que 'desligasse o rádio que estava incomodando' e ainda 'que o interrogando só incomodava' e dizendo isto a própria mãe desligou o rádio; QUE, o interrogando 'esperou um pouco' deitado no escuro, não podendo precisar o tempo que assim ficou; QUE, o interrogado apenas se recorda que subiu as escadas e acendeu a luz do hol 
superior e adentrando o quarto onde estavam seus pais passou a procurar uma arma que sabia que seu pai possuía, um revólver '38' [...]; QUE, o interrogando procurou então a arma no armário do quarto dos pais e não a encontrando procurou-a num gavetão que fica debaixo da cama do casal; QUE, dentre diversos objetos (sapatos e roupas), encontrou o revólver que procurava embrulhado em plástico e verificando, constatou que estava carregado; QUE, de posse da arma o interrogando foi para o banheiro, 'para tentar refletir' e para 'tentar assimilar alguma idéia'; QUE, 'estava tudo rodando' e o interrogando não ficou muito tempo no banheiro; QUE, indo para o corredor o interrogando 'permanecia atrapalhado', sem saber o que fazer, tendo nas mãos o revólver carregado;[...] QUE, foi neste momento que o interrogando ainda no corredor engatilhou a arma e a mesma disparou atingindo a folha da porta entreaberta do quarto do casal, atravessando-a; QUE, o interrogando esclarece que este disparo foi acidental, pois manobrava mal a arma; QUE nesse momento 'o interrogando não sabia o que fazer, e atrapalhou as idéias', vendo então sua mãe assustar-se, após acordar e 'dar um pulo na cama'; QUE, sua mãe 'não chegou a assimilar a idéia do que acontecera' e então o interrogando alvejou-a [...] com o barulho do disparo seu pai acordou e tentou levantar-se, ocasião em que o interrogando atirou atingindo-o [...]QUE, o interrogando 'não sabia o que fazer e agia automaticamente', assim, sua irmã ouvindo os disparos veio até o quarto dos pais e adentrou pela porta entreaberta [...] e que então o interrogando alvejou a irmã CRISTINA, acreditando o interrogando que Cristina nem mesmo o viu, não chegando a saber o que estava se passando [Roberto desceu ao pavimento inferior da casa em busca de mais munição para a arma] QUE, enquanto recarregava a arma o interrogando ouviu gemidos e 'pressentiu que havia alguém vivo' [então Roberto muniu-se de duas facas de cozinha, com as quais esfaqueou os corpos de seu pai e de sua mãe, que 
era quem gemia]; QUE o interrogando atravessou então o corredor e foi para o seu próprio quarto que partilhava com os irmãos PAULO e ANDRÉ [neste instante, Paulo acabava de levantar-se para ir ao banheiro, e Roberto esperou que voltasse e adormecesse novamente]; atirou na cabeça de Paulo [...]; QUE André, o caçula, continuava adormecido [...] e o interrogando foi até ele e repetiu o que fizera com Paulo, alvejando-o na cabeça; QUE, o interrogando então já vira a cena que provocara e então tomou a decisão de se desfazer dos corpos; QUE, o interrogando apanhou a chave do veículo Gol, de seu pai, foi até a garagem [e levou os corpos dos familiares mortos para o carro]; QUE, após acomodar os corpos no veículo [lavou o sangue que manchara a escada externa da casa, tomou banho e vestiu roupas limpas]; dirigiu o veículo até um determinado local [...] nas imediações de um cemitério, desceu do veículo, não se lembrando se trancou-o e saiu caminhando a pé, levando as chaves[...]. Amanhecia o dia 6JAN85. Roberto retorna, e inicia a limpeza de sua casa.

Este relato de Roberto será modificado várias vezes durante o processo: no interrogatório inicial, em 29JAN85, dirá que após a reprimenda da mãe sobre o incômodo do rádio, adormeceu no sofá e só acordou quando a polícia procurou-o, pela manhã, dizendo-lhe que seu pai sofrera um acidente de automóvel e que assinara a confissão constante no Auto de Prisão em Flagrante sob coação dos policiais; está claro que esta atitude deriva da orientação do advogado de defesa.

Durante as entrevistas com o psiquiatra forense nomeado como perito no Incidente de Insanidade Mental determinado pelo juiz por requerimento do Ministério Público, Roberto ainda tentará sustentar esta versão, até que o perito deixe-lhe claro que não acredita em sua amnésia; então Roberto reafirma seu relato inicial. 
Finalmente, o registro do interrogatório de Roberto diante do Tribunal do Júri Popular, em 18AGO87, deixa entrever em sua fala ambas as versões sobre os acontecimentos posteriores à repreensão da mãe: “por Deus, 'apaguei' vendo as coisas acontecerem por acidente, e não me recordo de nada" [...] Que as declarações que o interrogando assinou foram declarações feitas ao bel prazer pelas autoridades, e não representam suas palavras [...]. Que o interrogando não pode afirmar com certeza se teria cometido o crime; que 'apagou', e não sabe o que possa ter acontecido. Repetindo: o interrogando não nega o crime; 'aconteceu tudo tão rápido'; que 'apagou' e não sabe o que aconteceu'; retificando, repetindo, que o interrogando não sabe o que aconteceu; 'aconteceu tudo tão rápido, apagou e não sabe o que aconteceu; que gostava de sua família [...] que nunca passara pela cabeça do interrogando o cometimento do crime [...] que ao voltar ao contato com a realidade, ficou muito chocado, não sabia o que fazer. Não fugiu. Que não tem sentimento de culpa, para se sentir arrependido. Por essa razão, o que sente é saudade”.

É preciso dizer que nenhum dos elementos constantes do relato inicial de Roberto foram contestados pelas provas testemunhais ou periciais. Ao contrário, os testemunhos e as conclusões finais dos exames periciais apenas confirmam a versão inicial de Roberto, oferecida no Auto de Prisão, em todos os seus detalhes relevantes.

Importa muito mais, porém, fazer notar que até esse momento, ou seja, até a noite de 6JAN85, múltiplas interpretações eram possíveis para os acontecimentos daquele dia trágico. $\mathrm{Na}$ verdade, muitas foram apresentadas, através da imprensa e dos documentos jurídicos, como adiante será mostrado. Desde o mesmo dia, através da mídia, e principalmente a partir do dia 7JAN85, instalou-se na sociedade paulistana um amplo debate, com defesa e contestação de teses as mais díspares sobre 
a personalidade de Roberto, e sobre as razões de seu crime. Antes do dia 18JAN85, quando o promotor ofereceu a denúncia à justiça, parte delas havia sucumbido; restava apenas aquela cuja possibilidade a denúncia vinha consagrar. Depois, até o julgamento, todas as falas apenas podem corroborar esta interpretação. 
Capítulo 5:

O Estado contra Roberto 


\section{“O Estado contra Roberto..."}

Já não há caminhos fáceis à nossa frente; temos de contornar os obstáculos, pular por cima deles e isso porque temos de viver, seja qual for a extensão do desastre havido.

[D. H. Lawrence]

Formalmente, o processo jurídico contra Roberto inicia-se com a Denúncia, oferecida pelo Promotor Público em 18JAN85 e aceita pelo juiz. Mas antes disto, já falava a máquina tagarela da justiça: data de 8JAN85 um requerimento de relaxamento da prisão em flagrante, feito pelo advogado Décio, constituído por Roberto neste mesmo dia. No dia seguinte, o promotor manifesta-se contrário ao requerido, e em 10JAN85 o juiz decide pela manutenção da prisão em flagrante. Em 11JAN85, já Décio renuncia à defesa de Roberto. Antes de apresentar o conteúdo destes documentos, será conveniente acompanhar mais detidamente as notícias dos acontecimentos daqueles dias...

Roberto esteve sob custódia policial desde a manhã do dia 6JAN85, e sua prisão em flagrante foi oficializada no final deste mesmo dia, permanecendo então encarcerado na delegacia onde lavrou-se o Boletim de Ocorrência relativo aos homicídios.

No início da tarde do dia 7JAN85, Roberto foi transferido para a Casa de Detenção. Na saída da delegacia, respondeu às perguntas dos repórteres ${ }^{44}$. Neste ínterim, sua família era sepultada. O jornal Folha de São Paulo trazia uma reportagem sobre o crime.

\footnotetext{
${ }^{44}$ Faltam-me elementos para precisar com segurança a data e o local de realização desta entrevista, bem como o(s) repórter(es) presente(s). Pelo conteúdo transcrito da fita, e
} 
No dia 8JAN85, o crime seguiu sendo comentado pela imprensa escrita $^{45}$. A Folha de São Paulo publicou algumas frases de Roberto aos repórteres: estou muito atrapalhado e não tenho nada a declarar; agora, o melhor é morrer; acho que tenho problemas mentais, não tive consciência do que fiz; e estou moído por dentro e não consigo coordenar as idéias. Relatou, também, as impressões dos policiais e do diretor da Casa de Detenção, Luís Camargo Wolfmann, sobre ele: estava abatido, mas não demonstrava nenhum sinal de desequilíbrio mental; e estava sendo mantido sob cuidadosa vigilância para evitar que tentasse o suicídio.

A mesma matéria traz, no subtítulo Hipóteses criminais, a opinião de um advogado criminalista, José Roberto, conselheiro da secção São Paulo da OAB, sobre o provável desenrolar do processo penal: Certamente, quando for julgado, Roberto deverá ser denunciado pela Promotoria como autor de quíntuplo homicídio qualificado. Argumentos: agiu de forma a tornar impossível a defesa das vítimas e impelido por motivo fútil. Já à defesa, caberá sustentar desde a negativa da autoria à comprovação de que matou num instante em que era incapaz de se autodeterminar, ou seja, apresentava uma personalidade insana.

Em quadro separado, são publicadas algumas declarações de vizinhos e parentes, abonando a normalidade de Roberto; o jornal informa

relacionando-o com os informes do processo e dos jornais Folha de São Paulo (8JAN85) e Notícias Populares (5FEV85), parece acertado supor que tenha ocorrido no dia 7JAN85, estando Roberto dentro da viatura que o transferiu da delegacia seccional sul para a Casa de Detenção, concorrendo vários repórteres, porém, constando nesta gravação apenas o trecho no qual Roberto foi interrogado pelo repórter Carlos Eduardo, do Programa Cidade Aberta, da Rádio Difusora. Esta transcrição, porque se trata do único registro direto do discurso de Roberto e porque a utilizarei em vários momentos da minha exposição, está integralmente reproduzida no anexo I.

${ }^{45}$ Os títulos e nomes dos comentadores serão citados conforme apareceram nos jornais, na época. 
a declaração de seu tio Raul: Raul diz que o sobrinho "era um pouco violento. Respondia aos pais, uma vez até quis bater na mãe”. Meia hora depois, o próprio tio reconsidera: "ele era normal”, diz, usando o tempo pretérito para referir-se a Roberto. O delegado Newton Fernandes, chefe do Degran, afirma que, no momento em que populares tentaram linchá-lo, Roberto teria dito: já que não fiquei famoso como cantor, pelo menos vou ficar famoso assim.

Há ainda declarações do Secretário de Segurança Pública, Michel Temer, e do professor da Universidade de São Paulo, doutor em psicologia, Jacob Pinheiro Goldberg, comentando o caso. O primeiro hipotetiza que $a$ violenta reação do rapaz pode ter sido conseqüência da excessiva pressão do cinema pornográfico e da exibição das revistas que exploram o sexo nas bancas de jornais, "que sempre afeta os menos favorecidos $e$ desequilibrados"; como hipótese alternativa, sugere que o crime poderia ter sido causado por fatores psicológicos ou por um desequilíbrio nervoso violento. Conclui sugerindo a realização de um seminário sobre a violência contra a pessoa. O segundo relaciona o crime com o alívio de tensões acumuladas por muitos anos, desde a infância provavelmente, apontando que as relações de família são as mais densas e tensas da condição humana, porque nela imperam as noções de incesto, tabu e posse. Assevera, ainda, que se for feito o confronto do perfil psíquico do rapaz e do evento, é quase certeza que se descobrirá uma realidade acumulada de tensões, que não foram sublimadas, concluindo que nesse momento, esse moço é agente e vítima de uma realidade.

Neste mesmo dia, o jornal Notícias Populares trazia a manchete: Monstro da Zona Sul teve sono de anjo, sob a qual reproduzia trechos da entrevista realizada no dia anterior, informava as horas de sono e o que Roberto havia comido desde sua prisão. Trazia, também, algumas 
declarações de vizinhos e parentes, além da afirmação de um dos delegados que participou de sua prisão, Paschoal, de que Roberto teria perguntado se teria ou não direito sobre uma parte da herança dos pais.

Enquanto circulavam estas notícias, na Casa de Detenção Roberto tinha uma crise de choro, recebia a visita de uma tia e de uma prima, conversava com o diretor daquela instituição e, a pedido deste, realizava pequenos trabalhos de datilografia. Ainda neste mesmo dia outorgou à Décio o mandato para sua defesa. O diretor da Casa de Detenção diz aos jornalistas que considera Roberto um jovem frágil, que inspira muita dó, e que lhe ofereceu pequenos trabalhos burocráticos para evitar que entre em depressão; afirma ainda não considerar necessário pedir exames psiquiátricos mais acurados, pois o exame rotineiro de admissão naquela casa nada constatou de anormal ${ }^{46}$.

Décio, então, entrega à justiça o requerimento de relaxamento da prisão em flagrante. Embora sejam interessantes as razões técnicas que utiliza para argumentar a ilegalidade da prisão, para a presente discussão importa mais sublinhar as exortações que faz à justiça: primeiro, assinala que a prisão, se não se revestiu dos requisitos legais, deve ter sido efetuada para sensacionalismo que, como certamente é do conhecimento do ilustrado magistrado, crassou na espécie; depois, que: malgrado a repercussão do fato, que gera, naturalmente, a repulsa da sociedade (...) eis que se trata de um patri-matri-fratricídio, é correto afirmar-se que o requerente tem, ainda e felizmente, a segurança do processo da Lei e da Justiça. O documento ressalta que os dados objetivos colhidos no investigatório permitem considerar que Roberto não é perigoso, além de encontrar-se na face da adolescência e afirma que sua família quer tê-lo

\footnotetext{
${ }^{46}$ Estas declarações do diretor da Casa de Detenção foram publicadas pela Folha de São Paulo na edição de 9JAN85.
} 
consigo, para trazê-lo ao convívio social e, apesar de seu tresloucado gesto, não permitir que vá às masmorras de um presídio, para contatos ainda mais nefastos. Lembra que Roberto não se subtraiu à ação da justiça nem the criou embaraços, assegurando que não o fará, e conclui: ocorrida uma tragédia, só resta ao jovem Roberto responder por ela.

No dia 9JAN85, o Ministério Público manifesta-se pela manutenção da prisão, através do promotor Lázaro. Mais do que os argumentos técnicos defendendo a legalidade do flagrante, importa aqui sublinhar as observações que o promotor acrescenta em abono à sua recomendação: os crimes praticados pelo indiciado acham-se marcados pela hediondez, visto que trucidou sua família inteira, sacrificando as vidas de seus pais e irmãos. Assim, até que eventualmente se apure sua higidez mental, em nada se justifica sua soltura, pois, está mais do que correto que a justiça está a se deparar com duas hipóteses: a de crime de homicídio com várias qualificadoras, praticado por uma pessoa perversa e amoral, ou, a existência de um processo mental deteriorado por patologia que deverá ser diagnosticada por exame de insanidade mental, no momento oportuno (...) o indiciado confessou o crime em detalhes estarrecedores, havendo assim indícios claros de autoria, com prova plena da existência delituosa (...) não faz o mínimo sentido, legal, moral ou social, que se dê liberdade à um indivíduo, em nome de pressupostos formais, aparentemente, desatendidos. Os crimes causaram intenso clamor social, interferindo com a ordem pública sendo até mesmo de conveniência, que o indiciado permaneça preso, em benefício de sua própria segurança pessoal.

Neste dia, a Folha de São Paulo trazia, além das informações prestadas pelo diretor da Casa de Detenção sobre o comportamento de Roberto no dia anterior, diversos outros comentários sobre o caso. O 
mesmo promotor Lázaro, coordenador geral da Promotoria do $1^{\circ}$ Tribunal do Júri, explicava que um exame psiquiátrico para avaliar a insanidade mental de Roberto poderia ser requerido a qualquer momento, pelo advogado de defesa, pelo promotor ou pelo juiz. O diretor geral do Instituto de Classificação e Triagem, também professor de Medicina Legal da Faculdade de Medicina da USP, Nélson T. Candelária, esclarecia a natureza destes exames, e aventava duas hipóteses diagnósticas: esquizofrenia ou um transtorno anti-social de personalidade. Este último se caracterizaria pela incapacidade de se conter, ausência de sentimento de culpa, incapacidade de aprender com a experiência e de fazer julgamentos, entre outros. O Secretário da Justiça, José Carlos Dias, afirmava: fiquei chocado, simplesmente estarrecido com a história (...) [Roberto] é possivelmente um esquizofrênico. Wálter Ceneviva, jurista integrante da equipe de articulistas do jornal, informa sobre os dispositivos legais que permitem a exclusão de Roberto da herança de seus pais. Este comentário é feito em atenção à hipótese, atribuída por este jornal ao delegado Jorge, que efetuou sua prisão, de que este seria o motivo do crime pois a primeira preocupação do jovem, ao ser preso no domingo era saber se tinha direito à herança. Em quadro separado, Marta Suplicy, sexóloga; José Angelo Gaiarsa, psiquiatra; e Davi Cardoso, produtor, diretor e ator de filmes pornográficos; contestam com veemência as declarações do secretário de Segurança Pública, publicadas no dia anterior.

O jornal Notícias Populares traz as declarações do Secretário de Justiça, e ainda a explicação do crime oferecida por um médium, Edmundo Alvim: este rapaz [Roberto] vingou sua morte, ocorrida há cem anos, por causa de uma herança. Seus matadores, na época, foram os pais e irmãos, que ele, agora exterminou (...) Roberto, há cem anos, era o único herdeiro de uma imensa fortuna. Ocorre, porém, que suas vítimas de hoje quiseram 
apossar-se dela. E para isso tramaram um diabólico plano que culminaria com a morte do rapaz. Roberto foi assassinado barbaramente (...).

O desenrolar posterior do processo e seu desfecho final permitem notar que neste momento já estavam delineadas todas as interpretações possíveis $^{47}$ para o caso; por assim dizer, todos os dados estavam lançados. A decisão do juiz sobre o requerimento de relaxamento da prisão em flagrante de Roberto será, então, como que simples leitura das faces mais expostas destes dados. Contudo, isto não diminui a gravidade da decisão judicial, ao contrário: porque the cabe pronunciar a justa interpretação, a palavra do juiz determina o que, doravante, deverá subscrever tudo quanto se diga sobre o caso; equivale a determinar o que pode ou não ser dito sobre o caso.

\section{O incompreensível Roberto...}

Será conveniente arrolar as teses explicativas oferecidas até este momento: quanto às razões do crime, falava-se de pornografia do cinema, carma espiritual, conflitos familiares determinando em Roberto um estado emocional desequilibrado, distúrbios psiquiátricos de Roberto, e pretensão à herança. Quanto às possibilidades jurídicas de argumentação, ofereciamse duas teses possíveis à acusação, para a qualificação dos homicídios:

\footnotetext{
${ }^{47}$ Claro que este "possíveis" refere-se antes à possibilidade da sociedade paulistana aceitar ouvir e considerar uma dada interpretação, que ao universo abstrato de todas as interpretações enunciáveis sobre o caso.
} 
futilidade ou torpeza do motivo ${ }^{48}$; e três teses possíveis para a defesa, duas claramente enunciadas pelo Conselheiro da $\mathrm{OAB}$, negativa de autoria e insanidade mental; e uma apenas insinuada na argumentação de Décio, que privilegiava a assumpção da autoria e sugeria a investigação dos conflitos que desembocaram no crime ${ }^{49}$.

Então, no dia mesmo em que o juiz decidirá sobre o requerimento do relaxamento da prisão, a Folha de São Paulo exibe um quadro entitulado Advogado quer relaxar flagrante de matador. O Notícias Populares prefere a manchete: Advogado quer tirar monstro da cadeia. $\mathrm{O}$ juiz, acatando a argumentação do promotor, decide manter a prisão de Roberto. Imediatamente, Décio faz o pedido de habeas-corpus ${ }^{50}$. Mas a decisão do juiz, tanto quanto os títulos jornalísticos do dia, já indicavam a fragilidade da posição que Décio tentava manter; sua atitude era de defesa da absoluta legalidade dos procedimentos adotados em relação a Roberto, e postergava a formação de um juízo sobre o crime para depois das investigações cabíveis, que deveriam incluir a investigação da situação familiar que o antecedeu. A argumentação do promotor e, antes, as hipóteses apresentadas por José Roberto, caminhavam em sentido oposto: de antemão, consideravam Roberto perigoso, e irracional o motivo do crime; ademais, sopesavam, além da lei, a conveniência moral e social de

\footnotetext{
${ }^{48}$ A tipicidade do crime, quíntuplo homicídio, e as demais qualificadoras, agravantes e atenuantes, eram incontroversas: surpresa, crime cometido contra familiares, situação de menoridade do réu, etc.

${ }^{49}$ Em verdade, quando observamos que no dia 11JAN85 o jornal Notícias Populares informava as declarações de Décio, sobre ter informações de que um prolongado processo de conflito familiar deve ter sido, neste caso, o motivo que levou este moço a gestos tão violentos, devemos supor que já no dia 10JAN85 esta tese estava proposta.

${ }^{50}$ Antes do julgamento do habeas-corpus, já representado por outro advogado, Roberto renunciará a este pedido.
} 
sua eventual soltura. A decisão judicial fortaleceu esta última posição, enfraquecendo a primeira.

Para privilegiar a consideração do destino final das argumentações jurídicas inicialmente encetadas sobre o caso, passarei ao largo das teses sobre a pornografia, apresentada por Michel Temer, e sobre o carma, apresentada pelo médium espírita Edmundo Alvim, pois, na construção da verdade juspsiquiátrica sobre o caso, estas explicações não cumpriram qualquer função. A primeira foi contestada prontamente, como consta acima, e não mais retomada; quanto à segunda, o próprio jornal afirma tratar-se de uma explicação que, evidentemente, não irá convencer a justiça, só podendo, portanto, sua apresentação pública servir a outras finalidades cuja apreciação não caberia aqui. Antes de abandoná-las, porém, quero assinalar em ambas o potencial subversivo que guardavam.

Michel Temer além de trazer ao debate, embora deslocada, a questão da sexualidade, situava fora de Roberto e de sua família uma causa para o crime, que, portanto, dizia respeito à sociedade.

A explicação do médium carecia de lógica e abusava do maniqueísmo, simplesmente invertendo em sua fábula os ocupantes das posições de vítima injustiçada e de assassino cruel e usurpador; mesmo assim, talvez sua descrição do contexto emocional do crime estivesse mais próxima da realidade do que a tese, aceita integralmente, de que Roberto matou a família, com frieza e premeditada deliberação, para apoderar-se da herança. Edmundo Alvim enunciava uma outra temporalidade para a vida; esta a audácia que lhe permitia trazer à cena dos conflitos e dos interesses hereditários, simultaneamente, todas as gerações. É interessante notar que os homicídios reais, em meio àquela particular constelação familiar, promoveu exatamente a mesma coisa: o crime de Roberto tornou-o único 
herdeiro e deserdado, a um só tempo; por isto, tornou herdeiras ambas as suas avós - senhoras de idade avançada - fazendo imediatamente interessados na herança ambos os seus tios, paterno e materno, logo também os filhos destes, seus primos.

Será preciso deter-se um pouco mais no destino ulterior da tese do conflito familiar, defendida pelo professor Jacob Pinheiro Goldberg, em 8JAN85, e privilegiada pela linha de defesa traçada por Décio.

No dia seguinte à decisão judicial sobre o requerimento do relaxamento da prisão em flagrante, 11JAN85, Décio entrega sua renúncia, informando que ao avistar-se com Roberto na Casa de Detenção, este manifestou que embora quisesse manter o requerente [Décio] como seu defensor constituído está seguindo orientação exclusiva de seu tio Ricardo que insiste em que ele seja defendido por outro profissional. Todavia, neste mesmo documento de renúncia, Décio requer, ante os interesses manifestamente conflitantes do mandante e de seu tio, que revelam questões de ordem patrimonial, seja aberta vista dos autos ao Dr. Curador de Menores para que promova diligências necessárias as garantias do relativamente incapaz [Roberto].

Comentando a renúncia, a Folha de São Paulo limita-se à frase: $o$ advogado Décio, que obtivera uma procuração junto a Roberto, sem intermediação da família, se afastou do caso a pedido do rapaz.

O jornal Notícias Populares de 12JAN85, porém, traz uma coluna com declarações atribuídas à Décio, com detalhes sobre sua contratação e sobre a influência de Ricardo para que Roberto entregasse sua defesa a dois outros advogados - Tadeu, amigo de Ricardo, e José Roberto, o mesmo conselheiro da OAB que opinara antes sobre as estratégias de defesa possíveis. Estas declarações aparecem sob o título trama do tio para trocar 
advogado, encerrado com a frase: "tenho muita pena desse moço, mas não posso continuar a defendê-lo diante do comportamento do seu tio, de cujas atitudes até suspeito". Abre-se, então, novo título, a tese da defesa envolvia a família, cujo texto constitui-se quase inteiramente de declarações atribuídas à Décio: "Na verdade, eu não acho que este moço simplesmente saiu de sua cama, naquela madrugada, e armou-se de um revólver e de duas facas para matar a família inteira. Ele ainda está traumatizado, não dá para conversar direito com ele (...) é preciso que seu tio e outros parentes também ajudem a montar um quadro do que realmente aconteceu naquela madrugada. Pelo que eu já apurei, Roberto estava marginalizado pela família, estavam cobrando muito dele (...) havia um conflito familiar, que podia estar durando anos (...) nada justifica a chacina, mas havia um conflito familiar e este tio do rapaz, Ricardo, não tem interesse em que este conflito familiar seja explorado (...) ele não quer é que a linha da defesa apure este conflito familiar". Parte do conteúdo destas afirmações já fora publicado na edição do dia anterior, e aparecem novamente nas edições dos dias seguintes, acrescidas da observação, também atribuída à Décio, de que Ricardo estaria impedindo as apurações da defesa sobre o suposto conflito familiar para "evitar o que considera um escândalo maior".

O jornal Notícias Populares seguirá explorando suas declarações neste sentido até o dia 15JAN85, enquanto a Folha de São Paulo ignora-as completamente, embora tivesse publicado antes as explicações teóricas, genéricas, do professor Jacob Pinheiro Goldberg.

No dia 13JAN85, o domingo seguinte ao crime, ambos os jornais deixam de informar sobre as diligências relativas ao caso; a Folha traz uma reportagem de meia página entitulada liberdade, receita para 'curar' os conflitos familiares; o NP traz um pequeno artigo assinado por Edson Flosi, 
entitulado Roberto ..., o jovem que exterminou a família inteira. Ambas as matérias $^{51}$ tratam da mesma tese, mas de maneira radicalmente oposta: a análise de Edson Flosi permanece aderida às circunstâncias do caso, enquanto o repórter da Folha entrevista um antropólogo, uma psicóloga, três psiquiatras e duas sociólogas, mais alguns adolescentes, seus pais e uma avó, sobre o tema genérico do conflito familiar. Surgem referências a altercações provocadas por motivos prosaicos, como o modo de apertar o tubo do creme dental, etc. O contato entre Karin e Roberto, na noite do crime, aparece reduzido à fórmula dos pequenos desentendimentos, logo, os homicídios aparecem como incompreensíveis; é o que se vê no único trecho que menciona o caso: depois de um pequeno desentendimento com a mãe, ele matou toda a sua família.

Doravante, até o julgamento, nenhum outro profissional será consultado senão os juristas e psiquiatras forenses ocupados do caso. Em 30JAN85, o juiz instaura, a pedido do promotor, o Incidente de Insanidade Mental e pelo mesmo despacho nomeia curador de Roberto o advogado José Roberto. Para o campo jurídico, está descartada a tese do conflito familiar; a sociedade deixa de falar sobre isto. A verdade agora deve ser buscada pela psiquiatria forense, ou antes, pelos psiquiatras peritos designados para apresentar o laudo, Dr. Guido Arturo Palomba e Dr. José Roberto de Paiva.

\footnotetext{
${ }^{51}$ Estas matérias estão integralmente reproduzidas no anexo II.
} 


\section{Roberto, o epiléptico condutopata.}

Ganha destaque, então a tese da morbidez, que começara a articular-se já no Auto de Prisão em Flagrante, pelas insistentes perguntas das autoridades policiais sobre a normalidade de Roberto. No dia seguinte, o próprio Roberto dirá: acho que eu estou com um problema na mente; na transcrição da fita magnética onde esta declaração ficou gravada [anexo I], a frase surge após o registro de 21 interpelações do repórter, quando por seis vezes perguntou à Roberto se ele estava consciente do que fizera; mais 18 interpelações, e Roberto diz: acho que foi um problema de insanidade mental, a única coisa que eu posso precisar agora.

Neste mesmo dia, 7JAN85, a Folha de São Paulo informava que de acordo com a polícia, Roberto jamais esteve internado para tratamento psiquiátrico; na edição seguinte, 8JAN85, a primeira frase de Roberto surge ligeiramente modificada: acho que tenho problemas mentais. Entre os comentários, excluído o quadro das explicações oferecidas pelo professor Jacob Pinheiro Goldberg, já aparecem palavras e expressões como: problema psíquico, distúrbio psíquico, assistência psiquiátrica, desequilíbrio mental, assistência psicológica, depressão, personalidade insana, insanidade mental, manicômio judiciário.

No dia seguinte, 9JAN85, aparecem: depressão, exame psiquiátrico, epilepsia, insanidade mental, esquizofrenia, transtorno antisocial de personalidade. Nitidamente, passa a prevalecer nos comentários da imprensa o jargão psiquiátrico ${ }^{52}$. A hipótese de Nélson T. Candelária, de

\footnotetext{
${ }^{52}$ Este efeito pode ser, em parte ao menos, atribuído ao fato de que a primeira lista apresentada compartilha a página na qual está publicada a previsão do conselheiro da $O A B$
} 
que o exame de Roberto poderia revelar um caso de esquizofrenia ou um transtorno anti-social de personalidade, profetiza o resultado do laudo psiquiátrico, homologado apenas um ano depois, concluindo que Roberto padece de epilepsia condutopática - denominação equivalente à personalidade psicopática ou ao transtorno anti-social da personalidade (a patologia é igual, declara o perito ao Tribunal do Júri).

O Laudo de Exame de Sanidade Mental de Roberto constitui-se de 114 páginas, e o perito Dr. Guido Artuto Palomba foi ouvido como testemunha do juízo por duas vezes: a primeira, em 17OUT85, e a segunda, em 18AGO87, diante do tribunal do júri. Nesta última ocasião, solicitou-se que seu depoimento fosse registrado por estenotipista, resultando em 43 páginas datilografadas; os depoimentos do próprio Roberto e das demais testemunhas, registrados por escrivão, ocupam, em média, uma página e meia. Isto demonstra a importância atribuída pela justiça aos esclarecimentos prestados pelo psiquiatra sobre a personalidade de Roberto. O laudo apresentado compõe-se de uma primeira parte, onde estão reproduzidos os fatos criminais, segundo constam do Inquérito Policial; a denúncia, sintetizando as conclusões do promotor público; e um tópico denominado outros subsídios, que traz excertos de depoimentos de Roberto e de testemunhas, constantes dos autos, mais trechos de sua entrevista com os repórteres [anexo I].

sobre as estratégias de defesa possíveis no caso: para o leitor, a tese da negativa de autoria era inteiramente descabida frente a todas as evidências, corroboradas pela confissão de Roberto (embora isto não impeça a que este mesmo advogado, quando conquistar o caso, venha a tentar esta estratégia); restava aceitar a explicação da insanidade mental (fortalecendo o jargão psiquiátrico), posto que o mesmo advogado, até então único jurista a falar sobre o caso, argumentava pela futilidade do motivo, que não se presta a explicar o crime - dizer que foi praticado por motivo fútil é o mesmo que dizer que não houve motivo, causa, razão. 
Seguem-se os antecedentes familiares, onde a avó materna e Paulo surgem como suspeitos de padecer de alguma sócio-neuropsicopatia, aquela por ser referida pelas testemunhas como neurótica de guerra, cismada; este por haver notícia de que havia, dos 8 aos 13 anos, recebido tratamento psiquiátrico ambulatorial porquanto apresentava disrritmia $^{53}$. Nos antecedentes pessoais, o perito assinala enurese noturna até os cinco anos de idade, e sonhos de estar perdido numa floresta que provocavam o despertar; informa que Roberto não se interessa por política nem por religião; também conclui, de suas reprovações escolares e mudanças de emprego, que Roberto, em suma, não gostava de estudar e trabalhar. Ainda neste ítem, o perito faz constar informações e opiniões colhidas junto aos tios de Roberto, Ricardo e Raul, que não diferem do que já haviam declarado à polícia e à imprensa.

No tópico versão do examinando sobre o delito, o perito conta, na forma de um diálogo semelhante ao que ocorrera, como dissuadiu Roberto a confessar-lhe o crime, após mais de 8 dias de entrevistas. Começarei reproduzindo o final da primeira fala do perito: (...) sucede que, se você continuar negando, relatarei isso no laudo, juntamente com o seu cinismo, dando margem a acharem, inclusive, que você já de há muito vinha premeditando o crime. Roberto contesta a premeditação, assumindo a autoria do crime. Em seguida, narra os episódios daquela noite até o momento da repreensão pelo volume do rádio: Aí minha mãe desceu novamente (...) ela me deu uma bronca que nunca tinha dado antes, e desligou o rádio. O psiquiatra pergunta: Você lembra da música, Roberto? (...) Por favor, escreva aqui para mim o nome dela.

\footnotetext{
${ }^{53}$ Esta informação, que o perito atribui ao tio, Ricardo, não foi confirmada pelo depoimento de quaisquer das testemunhas, durante o processo.
} 
Vários outros momentos deste diálogo serviriam para ilustrar o tom que o perito imprimiu à entrevista; utilizei estes trechos iniciais porque deixam suficientemente clara a intenção do psiquiatra de tão somente corroborar as hipóteses que já trazia formuladas, e a falta de interesse igual à da polícia e da justiça - de informar-se sobre o conteúdo da repreensão feita por Karin a Roberto. É notável o deslocamento da ênfase para o nome da música que Roberto estava ouvindo no momento da repreensão: além de registrá-lo na transcrição da entrevista, o perito anexa ao laudo a folha de papel aonde Roberto o escreveu [mencionado como documento 2], junto com o registro do encefalograma. Na conclusão do laudo chegará a dizer: se [Roberto] é abúlico às atividades úteis - haja vista que abandonou os estudos e foi inconstante nos empregos - por outro lado é perseverante e fixo em outro tema: a música. Chegou, inclusive, a afirmar: 'sem música eu não vivo, eu escuto música o dia inteiro'. E também, resolveu levar a cabo hediondo crime quando a mãe desligou o rádio que estava a tocar 'Year of the cat', como bem afirmou e escreveu aos peritos (doc.2). São os contrastes do epiléptico, que sempre paga tributo à sua tara. Ora, está claro que Roberto não afirmou ao perito haver matado sua família porque a mãe interrompera sua audição da música 'Year of the cat'; à coisa bem diversa da epilepsia deve-se tributar seu crime. Mas seria igualmente injusto exigir que o perito tivesse suportado ouvir Roberto queixar-se dos sentimentos provocados pela repreensão de Karin.

Os exames físico e neurológico nada revelaram de significativo. O exame psíquico, efetuado através das entrevistas, revelou ao perito que Roberto tinha gosto pelo ócio, o seu esforço nunca teve continuidade. Estas conclusões contrariam a opinião de todos os que falaram sobre a conduta de Roberto, inclusive dois ex-patrões e exceto a opinião isolada de seu tio Raul. Deve ser lembrado que Roberto não abandonara os estudos, mas um 
curso profissionalizante de desenho mecânico; quanto aos empregos que teve, conforme os depoimentos dos ex-patrões, deixou-os por razões alheias à sua vontade, exceto o último, do qual pediu demissão após candidatar-se às provas de seleção no banco - talvez já estivesse, inclusive, aprovado; isto não foi apurado.

Segundo o perito, Roberto também não teria um móvel que sirva de mola para o futuro. Quanto a afetividade, é indiferente, mormente no que diz respeito aos fatos delituosos dos quais foi autor. O perito ainda observa que de quando em vez se lhe ocorre episódios de 'déjà vu', e que $o$ humor é, aparentemente, estável. Porém, quando contrariado nos seus propósitos torna-se violento. $\dot{E}$ de notar, entretando, que a sua agressividade deriva para o vaguear sem rumo. Isto é, ao invés de explodir e agredir, sai andando sem rumo(...) notamos, entretanto, que, durante esta poréia (marcha em grego) ele não perde a memória nem apresenta quaisquer outros distúrbios psíquicos.

Sobre a avaliação do humor de Roberto, deixarei assinalada a contradição entre ser violento e derivar a agressividade para o vaguear sem rumo; ora, é próprio do humor violento a incapacidade de derivar a agressividade para uma atividade não violenta. Deve merecer atenção, também, o fato de Roberto estar, na época, respondendo uma ação penal por quíntuplo homicídio - como fazer planos para o futuro nesta condição?

Quanto ao indiferentismo afetivo, o próprio perito declara depois, em seus depoimentos, que o descobriu principalmente em duas frases de Roberto, que deixarei em negrito. Respondendo à pergunta do perito: quando atirava, o que lhe passava pela cabeça? Afinal você estava atirando no seu pai, na sua mãe e nos seus irmãos? Roberto diz: Doutor, é como se eu estivesse atirando em sacos de batatas; a próxima pergunta do 
psiquiatra é: Roberto, uma coisa eu não entendo: concordo que você tivesse motivos para matar o seu pai, afinal, ele não the emprestava o carro, não lhe dava dinheiro, vivia se indispondo com você; concordo que você tivesse motivos para matar a sua mãe, que vivia te amolando com o negócio do som alto, etc.; concordo que você não suportasse a Cristina, a qual você tinha uma certa vergonha e que vivia te cutucando como você mesmo falou; concordo também com a sua aversão ao Paulo, que era aplicado nos estudos e você não ${ }^{54}$, mas uma coisa eu não consigo entender: e o André que era muito seu amigo. E o André? (...) Roberto responde: Doutor, é aí que eu não sei. O senhor conhece o leão que morde todo mundo e quando chega perto do domador morde ele do mesmo jeito que aos outros, sem dar ao menos uma recuadinha.

Quanto à primeira resposta, seria preciso contrastá-la com várias outras declarações de Roberto, à imprensa e em juízo, de que se sentia corroído por dentro, de que sentia saudades de sua família, de que seria melhor morrer que suportar sua tortura mental por se saber autor dos homicídios, etc. Aqui, parece, ele responde unicamente pelo que the passava pela cabeça, como perguntou o perito, não por sua afetividade. Sua resposta demonstra apenas que no momento do crime não agia com inteira clareza sobre o que fazia, ou que, durante a entrevista, não conseguia formular melhor resposta à pergunta do psiquiatra. Quanto à segunda resposta, parece bem adequada à insensatez e/ou capciosidade com que a pergunta foi formulada; ou será mesmo crível que o psiquiatra tenha sido honesto em sua avaliação dos motivos que Roberto teria para matar Mário, Karin, Cristina e Paulo?

\footnotetext{
${ }^{54}$ Note-se que apenas a observação sobre sentir vergonha de Cristina o perito colheu diretamente de Roberto. As relativas a Mário e Karin constam da denúncia (e adiante ficará
} 
Em síntese, o perito conclui que Roberto padecia de epilepsia forma condutopática, sustentando este diagnóstico como segue: a epilepsia do examinando pode ser observada através de vários sintomas e sinais bastante significativos. A saber: equivalentes comiciais [elenca: cefalalgia esporádica na região occipital, escurecimento de vista, pavor noturno com sonhos repetitivos e enurese noturna até os cinco anos, alguns episódios de 'déjà vu'], o humor explosivo, a poriomania, a abulia, a frieza de sentimentos e a morfologia do crime.

A precariedade das bases que sustentam este diagnóstico já está quase inteiramente apontada nos comentários às conclusões do perito sobre o exame psíquico de Roberto. Restaria apenas apresentar o modo como o perito apóia o diagnóstico sobre a morfologia do crime. Diz Palomba: a nossa experiência mostra que os crimes praticados pelos epilépticos, crimes violentos, na sua grande maioria tem, no mínimo, quatro destes sete [característicos] distinguidos por DU SAULE, e o examinando, por ser epiléptico e haver praticado crime hediondo, não é, como veremos, exceção à regra. Os característicos aludidos são: 1. Ausência de motivos; 2. Ausência de remorsos; 3. Falta de premeditação; 4. Instantaneidade do ato; 5. Ferocidade na execução; 6. Multiplicidade de golpes; e 7. Amnésia. Palomba reconheceu no caso de Roberto a ocorrência dos característicos enumerados em 1, 2, 3, 5 e 6; e descartou a instantaneidade do ato, pois Roberto teria esperado até que todos dormissem, e a amnésia ${ }^{55}$.

Antecipando-se às críticas dos juristas, o laudo afirma que o resultado normal do EEG não invalida o diagnóstico, e apresenta ainda

claro que não têm fundamento), e a relativa a Paulo é uma inferência do psiquiatra, não confirmada por Roberto. 
longas justificativas teóricas sobre a ausência de exames neurológicos e psicológicos através de instrumentos mais sofisticados. Finalmente, é abordada a questão da responsabilidade legal de Roberto, em face do diagnóstico apresentado.

Do ponto de vista jurídico, tal patologia implicaria na semiimputabilidade; esta conclusão foi acatada unanimemente pelos jurados ${ }^{56}$, mas talvez o símbolo maior da vitória da tese da morbidez resida na imediata substituição da pena ${ }^{57}$ por medida de segurança, de tal sorte que Roberto permanece, desde então, recolhido ao manicômio judiciário. Contudo, não venceu sozinha. Esta composição entre medida de segurança e pena - entre diagnóstico e julgamento, entre manicômio e cárcere, entre loucura e crime - deve trazer de volta a lembrança do momento em que, ainda em 10JAN85, decidindo sobre o pedido de relaxamento da prisão em flagrante formulado por Décio, o juiz fortalecia os argumentos do promotor, de que o caso de Roberto deparava a justiça com duas hipóteses: a de crime de homicídio com várias qualificadoras, praticado por uma pessoa perversa e amoral, ou, a existência de um processo mental deteriorado por patologia. Realmente, para explicar o crime de Roberto, a justiça precisou lançar mão de ambas as hipóteses ${ }^{58}$.

\footnotetext{
${ }^{55}$ No capítulo As confabulações psi sobre os homicídios violentos, a categoria nosográfica da epilepsia condutopática será analisada com maior profundidade, a partir do livro Loucura e Crime, do próprio Guido Arturo Palomba, publicado onze anos após a elaboração deste laudo.

${ }^{56}$ Cumpre esclarecer que os jurados votaram, primeiro, o quesito relativo à tese da inimputabilidade, rejeitada por 6 votos a 1; depois, votaram a tese da semiimputabilidade,aprovada, como informado acima, por unanimidade.

${ }^{57}$ O júri julgou-o culpado, nos termos da pronúncia, e, como conseqüência, Roberto foi condenado, em última instância, à pena de 25 anos de reclusão.

${ }^{58}$ Por oportuno, faço notar que, no discurso do Direito Penal e de certa forma também da psiquiatria forense, torpeza e loucura são categorias excludentes por princípio. A primeira implica uma deliberação perversa, e a segunda implica uma doença que perverte a capacidade
} 


\section{Roberto, o assassino torpe...}

Paralelamente à tese da morbidez, construía-se a argumentação sobre a torpeza do motivo do crime, baseada unicamente na pergunta de Roberto a respeito dos bens de seus pais. Atribuída inicialmente aos delegados Jorge e Paschoal, esta será a tese defendida pelo promotor público na denúncia e, após todo o processo, será aceita pelo júri, a despeito de que nenhuma prova veio aboná-la. Será preciso acompanhar sua construção, simultaneamente, na imprensa e nas esferas policial e jurídica.

Na edição de 8JAN85, o jornal Notícias Populares encerra sua matéria sobre o crime com o seguinte parágrafo: dona Célia, antiga moradora da rua, não tem palavras para comentar a chacina. Com os olhos cheios de lágrimas, ela se recorda do menino meigo que, aos 8 anos, lavava os carros da vizinhança [refere-se a Roberto]. Um menino que, de certa forma, perdeu muito de sua meiguice. Afinal, sua preocupação junto ao delegado [Bel. Paschoal] era saber se terá ou não direito a alguma parte da herança dos pais.

Em 9JAN85, quando a Folha de São Paulo publica os esclarecimentos de Wálter Ceneviva sobre a questão da herança, informa em seguida: A hipótese de Roberto ter assassinado os pais e três irmãos, como forma de se apoderar da herança, foi levantada pelo delegado [Bel. Jorge]. Segundo ele, a primeira preocupação do jovem, ao ser preso domingo, era saber se tinha direito à herança. Cumpre notar que esta informação não consta do depoimento prestado pelo delegado Jorge, no

de deliberar. Penso que a categoria nosográfica psicopatia, neste caso convertida em epilepsia condutopática, procurou apaziguar precisamente este conflito 
Auto de Prisão em Flagrante, nem em qualquer dos documentos lavrados naquele dia. Se surge na imprensa, dois dias depois, isto indica que algum dos policiais presentes na situação (a referida pergunta teria surgido durante o transporte de Roberto, de sua casa até a delegacia), Paschoal, Jorge ou qualquer outro, comentaram o episódio com os repórteres e que, provavelmente, fizeram-no sem estabelecer, de fato, conexão entre a preocupação de Roberto e o motivo do crime. Caso contrário, este episódio teria sido relatado no Auto de Prisão em Flagrante, pois é sabido que a apuração dos possíveis motivos do delito é parte importante das investigações policiais.

Ainda em 16JAN85, quando o delegado Ismael apresenta à Justiça o Relatório do Inquérito Policial, nenhuma menção é feita ao motivo do crime, nem à questão da herança, que já vinha sendo focada pela imprensa. Entretanto, na denúncia oferecida pelo promotor, em 18JAN85, fica afirmado que: várias qualificadoras, M.M. Juíz, estão a se inserir nas condutas criminosas praticadas pelo acusado. Foram delitos deliberados pelo motivo $\underline{T} \underline{O} \underline{R} \underline{P} \underline{E}$-pois, há veementes indícios nos autos de que o acusado pretendia ficar com todos os bens da família. À sua noiva não escondia os planos de montar uma sorveteria, malgrado não tivesse os mínimos recursos para tanto, havendo notícias de que, anteriormente, tentara agredir a sua genitora, visando extorquir-lhe dinheiro. O seu primeiro pensamento, após consumar os crimes, foi o de se apossar de ambas as chaves dos carros pertencentes ao seu pai. Estas chaves foram encontradas, junto a sua cabeceira, no seu quarto de dormir, havendo seguras informações, que antes dos crimes, seus pais não the davam as chaves dos veículos, sob qualquer título. Preso em flagrante, sua preocupação maior junto às Autoridades e jornalistas, era a de indagar 
sobre 'como ficaria sua herança'(??)' (a este trecho, segue-se a apresentação das qualificadoras "meios cruéis" e modo que "impossibilitou a defesa das vítimas").

Embora sem qualquer pretensão ou interesse em verificar aspectos factuais do caso, será preciso contrastar estas afirmações da promotoria com as provas testemunhais disponíveis até este dia 18JAN85, para demonstrar que sua convicção quanto ao motivo torpe do crime fundase sobre o relato da imprensa, não sobre aquelas provas. Sobre os temas abordados pelo promotor, depõem Adriano [namorado de Cristina], no Auto de Prisão em Flagrante, e Judite, em 11JAN85.

Adriano diz: QUE, respondendo a pergunta da autoridade, o depoente esclarece que a família tinha dois veículos, um Gol e um VWsedan, e que o acusado Roberto... não tinha chaves desses veículos, e quando precisava usá-los, ou queria usá-los, pedia as chaves ao pai, sendo certo que o depoente tem conhecimento desses fatos, pois viu pessoalmente uma vez quando o pai negou as chaves à Roberto, e em outra ocasião tomou conhecimento de fato semelhante, por intermédio da namorada Cristina.

Judite diz: QUE a depoente também se recorda que Roberto lhe dissera que pretendia montar uma loja de discos com o apoio da mãe, mas esse plano fora antes de Roberto conhecer a depoente; QUE, já durante o conhecimento, ou melhor, o namoro com a depoente, Roberto também, com o apoio da mãe, manifestara o desejo de estabelecer-se com uma sorveteria e ser, assim, independente.

O contexto no qual aparecem as afirmações de Adriano sobre as chaves dos carros deixa claro que respondia às perguntas da autoridade policial que presidia o depoimento, o delegado Ismael, e que esta 
autoridade tratava de investigar se as chaves do Gol que haviam sido encontradas na casa eram as únicas existentes para aquele veículo, de forma a não restar dúvidas sobre haver sido Roberto a conduzir o Gol até o local de encontro dos cadáveres e voltar à casa, levando consigo estas mesmas chaves. Adriano não diz que os pais de Roberto não lhe davam as chaves dos veículos sob qualquer título. Ao contrário, fica evidente que quando Roberto precisava usar, ou queria usar um dos carros pedia as chaves ao pai, certamente porque contava que as emprestasse, ainda que em algumas ocasiões o pai não o fizesse.

Também o depoimento de Judite não serve como sustentação para as afirmações da Denúncia. Nenhum dos testemunhos registrados até então afirma que Roberto tentara agredir sua mãe, para extorquir-lhe dinheiro. Apenas Raul, em declaração à imprensa, publicada pela Folha de São Paulo em 8JAN85, dissera que Roberto era um pouco violento. Respondia aos pais, uma vez até quis bater na mãe.

A partir da denúncia, porém, a hipótese de que a herança pudesse ser o motivo dos homicídios passa a orientar as investigações complementares ao Inquérito Policial. As testemunhas ouvidas desde então são argüidas diretamente sobre os "fatos" ali apresentados. Raul diz, em depoimento datado de 30JAN85: QUE, Roberto, por essa época (quando completou 16 anos), passou a não mais respeitar os pais, chegando, as vezes, a gritar com a mãe e quase chegar a agressão, embora não afirme, em qualquer momento, que esta atitude visasse extorquir-lhe dinheiro. É preciso notar, ademais, que esta afirmação sobre o comportamento desrespeitoso e agressivo de Roberto em relação aos seus pais é isolada. Os depoimentos de vários vizinhos da família, ouvidos durante a Instrução, bem como de outras testemunhas, arroladas em razão de haverem presenciado o relacionamento de Roberto com seus familiares, atestam, ao 
contrário: "Nessas oportunidades, eu nunca observei qualquer sinal de agressividade ou hostilidade do réu para com seus familiares, ou viceversa. O que sempre chamou a minha atenção foi a docilidade do réu, bem como sua educação e seu tratamento para com todos, se prestando, inclusive, para, com habilidade, intervir nas brigas entre os meninos da região”(Sidney, vizinho, em 17OUT85); “Eu sei que o réu recebia o salário pelo seu trabalho (quando trabalhava para Ricardo, tio materno), isto porque ele tinha dinheiro para comprar as coisas e chegava mesmo a fornecer dinheiro à sua mãe quando estava 'apertada'(...) o comportamento do réu com o seu pai era normal, lembro inclusive que o réu se despedia do pai com um beijo, quando este nos dava carona até o metrô" (Júlia, em 17OUT85); "O réu era o filho que melhor se relacionava com sua mãe. O réu não tinha qualquer divergência com seu pai" (André, primo de Karin, em 17OUT85); "que no dia 26 de dezembro (1984), a depoente esteve na casa do acusado e lhe foi dito por sua mãe (Karin), que a pessoa que mais lhe estava dando apoio, em face dos problemas com Cristina, era o próprio acusado" (Luely, vizinha e amiga de Karin, em 18FEV86). Parentes e vizinhos mais próximos afirmam que Raul freqüentava muito pouco a casa, colocando sob suspeita seu depoimento.

Outro aspecto da denúncia que passa a ser investigado é o plano de Roberto de montar uma sorveteria, malgrado não tivesse os mínimos recursos para tanto. Judite é interrogada numa segunda ocasião (170UT85), e responde: Presenciei quando o réu e sua mãe 'faziam planos' para montar uma doceria, sendo que eu me limitaria a 'ajudar'. Ou seja: Roberto fazia planos com sua mãe, e isto explicaria o primeiro depoimento de Judite, de que Roberto contava com o apoio da mãe. 
Em 22FEV85, por determinação do juiz, o delegado Ismael solicita à polícia científica a transcrição de uma fita magnética na qual encontra-se gravada a entrevista da imprensa com Roberto, e junta-a ao processo. O respectivo laudo da transcrição data de 29JAN85. No dia 30JAN85, tratando de averigüar se Roberto tivera um cúmplice, também interessado na herança, para a execução dos homicídios, Ismael interroga Orlando (irmão de Judite, que levou Roberto para casa na noite do crime) pela segunda vez, e em dado momento fá-lo ouvir um trecho da fita: $Q U E$, o depoente ouviu uma gravação nesta delegacia em que Roberto menciona uma frase que diz: 'a gente ia dividir tudo em dois', e o depoente nega que entenda o significado da frase ou que relação ela possa ter com quem quer que seja; QUE, nega que esta frase tenha relação com o depoente.

Leia-se a transcrição da fita, como consta do processo, no trecho aludido (legenda adotada: $\mathrm{R}=$ repórter; $\mathrm{I}=$ Indiciado, Roberto):

R: E o negócio da herança, Roberto, que você fala?

I: Eu não quero herança.

R: Não tem nada?

I: Não tenho, não tenho, não tenho nada a receber.

$R$ : Estava precisando de dinheiro?

I: Não, não devia nada pra ninguém.

R: Mas você ia casar, né? 
I: Ah, mas quanto a isso a gente ia dividir tudo em dois. (Este sublinhado encontra-se, a caneta, na transcrição que consta do processo. Esta é a única frase sublinhada.)

R: Então, por que você fez essa pergunta pro delegado se você ia ficar com a herança ou não?

I: Não, eu, não foi bem herança que eu queria. Eu queria saber se eu podia pegar uma parte do que tem, que a gente possuia, pra poder sair. Sair pra longe, sair de São Paulo.(a partir deste ponto, o repórter enfoca outro assunto).

Hoje, parece evidente que Roberto referia-se às despesas de casamento quando disse que quanto a isso a gente ia dividir tudo em dois. $\mathrm{Na}$ época, a frase levantou suspeitas sobre um possível co-autor para o crime e reforçou a hipótese da herança como seu motivo. Mesmo a leitura da transcrição realizada pela polícia científica não bastou para desfazer a interpretação equivocada, e o sublinhado demonstra isto. Mais ainda, esta interpretação seguiu sendo explorada, como no interrogatório de Orlando e de Judite. As suspeitas sobre o auxílio de um cúmplice apenas são afastadas em razão de provas materiais, especialmente a ausência de outras impressões digitais nas cenas do crime.

Quanto à hipótese da herança como motivo para os crimes, persistiu até o julgamento final. Mesmo sem nenhuma prova abonadora, o júri acata a tese do motivo torpe para os cinco homicídios, defendida no libelo-crime. No resultado do julgamento, ficará um vestígio concreto de sua inconsistência: todos os quesitos foram votados unanimemente pelos jurados, exceto o $3^{\circ}$ de cada série, que afirmava a condição de inimputabilidade, e o $5^{\circ}$ de cada série, que afirmava a torpeza do motivo do 
crime - Roberto teria assassinado os pais para se apoderar da herança, e os irmãos para restar como único herdeiro ${ }^{59}$.

Cumpre informar que o processo penal de Roberto compõe-se de quatro volumes, que registram os feitos da ação principal, ou seja, os relatórios de investigações e diligências, os laudos periciais, interrogatórios do réu, depoimentos de testemunhas e peritos e as manifestações da justiça - as falas dos manipuladores técnicos. Há ainda dois apensos: um, tratando do Incidente de Insanidade Mental, e outro constituído pela cópia dos autos da ação sucessória (cível) sobre os bens da família. A este último não tive acesso, pois não se encontrava de fato apensado ao principal na ocasião da consulta; segundo a explicação da instituição que o guardava isto se devia a tratar-se de um tema relativo à vida privada das pessoas envolvidas, cuja intimidade deveria ser resguardada pela justiça. Não obstante, a notícia de sua existência tive-a nos autos do processo penal: é que na fase de instrução, o juiz determinou o apensamento da cópia desta ação cível, para dela tomar conhecimento e instruir-se quanto à nomeação de tutor para Roberto. Esta cisão precisa ser assinalada: embora a questão da herança adquira centralidade absoluta na discussão jurídica sobre o crime, o processo penal faz referências muitíssimo breves à herança real - aos bens, aos regulamentos legais de sua transmissão, aos procedimentos jurídicos de decisão quanto à sua distribuição. As ponderações sobre o motivo do crime adquirem, então, o aspecto de pura abstração sobre os desejos de Roberto, sobre suas ambições, de estabelecer a doceria, de dirigir o carro do pai, de casar-se com Judite.

Como compreender que uma tese assentada sobre bases tão precárias tenha prosseguido, irrestritamente aceita, através de todas as

\footnotetext{
${ }^{59}$ Este quesito foi aprovado por cinco votos contra dois.
} 
instâncias da justiça? Parte da resposta, fundamentada pela discussão precedente, é que isto pôde ser afirmado na denúncia, e reafirmado até o desfecho final do processo, porque esteve fortalecido desde a primeira decisão judicial sobre o caso, no dia 10JAN85. Equivale a dizer que seu desmentido esteve enfraquecido desde este dia no qual, como sugeri acima, todos os dados estavam lançados.

Mas ainda não é toda a resposta. Será preciso compreender porque policiais, juristas, jurados, psiquiatras, jornalistas, vizinhos, amigos e parentes de Roberto tornaram-se cegos, surdos ou calados sobre as circunstâncias que cercaram o crime, solidarizando-se assim, em maior ou menor grau, na construção de uma imagem ao mesmo tempo insana e torpe para Roberto, a imagem de um monstro. 


\section{Capítulo 6:}

Roberto, o monstro da zona sul. 


\section{Roberto, o monstro da Zona Sul.}

O jornal Folha de São Paulo, em sua edição de 7 de janeiro de 1985, sob o título Rapaz chacina pais e três irmãos a tiros e facadas, dános, na página geral, a notícia:

“Com um revólver calibre '38' e um facão de cozinha, Roberto..., dezoito anos, estudante, matou, um a um, o pai Mário..., 46 anos, a mãe Karen..., 42 anos, e os irmãos, Paulo, dezessete anos, Cristina, dezesseis, e André, oito anos. O crime - um dos mais brutais já verificados na Capital nos últimos tempos - aconteceu pouco depois de 1h30, na residência da família, um sobrado na rua..., na zona sul de São Paulo.

Os corpos das vítimas foram descobertos ontem pela manhã, numa rua de terra, sem saída, a menos de dois kilometros da casa. As seis horas, José Barbosa..., trinta anos, pedreiro de uma casa em construção no local, percebeu quando um rapaz magro, branco, cabelos curtos, calça branca e camisa azul clara, estacionou um Gol cor ouro metálico, placa..., de propriedade da família, e saiu tranquilamente, abanando as chaves do veículo em uma das mãos."

Ao trecho acima, seguem-se dois sub-títulos: Quebra-cabeça e Sem explicações, traduzindo a perplexidade causada pelos crimes. Esta 
perplexidade acha-se resumida na frase: "A brutal violência do crime não encontrou qualquer explicação razoável entre os que o conheciam”. Havia um enigma, que agora alcançava o grande público: porque Roberto matara seus pais e irmãos?

Noutro enigma, porém, concentra-se este estudo. Ao texto da reportagem deve-se, antes de responder, perguntar. E a pergunta mais simples é sobre quem o escreveu; mas nada responde. $\mathrm{O}$ anonimato remete sua autoria diretamente para o jornal Folha de São Paulo, cujo prestígio e imagem de isenção contagiam imediatamente o texto, conferindo a todas e a cada uma de suas palavras e afirmações a aura da verdade. Mas também deixa aberta, no lugar do sujeito deste discurso, uma lacuna passível de ser preenchida por qualquer leitor; o texto apresenta-se como o discurso de todos e, para subtrair-se a endossá-lo, cada leitor precisaria fazer um esforço ativo. Outra pergunta simples seria sobre a resposta oferecida pelo jornal ao enigma proposto; novamente nada responde. O silêncio, porém, sustenta a demanda pela resposta. Quem demanda? Que gênero de resposta é qualificado como suficiente? Quem é demandado? A primeira pergunta encontra sua resposta no anonimato: todos demandam, todos querem saber porque Roberto chacinou sua família. Porém, não bastará para atender a isto qualquer gênero de resposta; é preciso encontrar uma explicação razoável. A própria reportagem informa que os conhecidos de Roberto não sabem a resposta, e menciona a declaração de Judite ("disse que Roberto era uma pessoa normal") e de seu tio Ricardo ("não há como entender"). Mas, em seguida, acrescenta que: "De acordo com a polícia, Roberto jamais esteve internado para tratamento psiquiátrico". Enquanto a afirmação do tio, aparecendo como transcrição literal, é atualizada para o leitor, a afirmação da namorada é narrada, aparecendo no pretérito: Roberto 
era uma pessoa normal". De qualquer maneira, esta declaração está invalidada pela afirmação anterior de que "a brutal violência do crime não encontrou qualquer explicação razoável entre os que o conheciam”. A sugestão é clara: para chacinar sua família, como fez, Roberto deve ser anormal, e sua anormalidade é assunto psiquiátrico. A demanda dirige-se, então, prioritariamente aos psiquiatras; eles têm competência para responder sobre o assunto.

Uma outra questão: quem é desqualificado para oferecer resposta ao enigma proposto? A isto, o texto responde especialmente por sua distribuição. O sub-título Sem explicações segue precisamente o trecho (entitulado como Quebra-cabeça) no qual o jornal apresenta (sua versão para) a versão e a explicação de Roberto para o crime. A reportagem diz: "Com a chegada da polícia começou a montagem de um quebra-cabeça que persistiu sem solução até o meio da tarde, quando Roberto confessou o crime”. Entretanto, a confissão de Roberto não solucionou o quebracabeça, ao contrário, complicou-o. É precisamente a partir desta confissão que se configura o enigma; tivesse a polícia constatado ali um caso de latrocínio e tudo estaria melhor encaixado. Mas a polícia constatou que o membro sobrevivente da família morta era o assassino, e obteve dele a confissão e sua explicação para o crime. Isto é que resulta sem explicação. Roberto está desqualificado para responder porque chacinou sua família. Sua explicação não explica, confunde. Sua explicação é parte do quebracabeça que a polícia trata de resolver.

Finalmente, deve-se perguntar ao texto: que opinião formar sobre Roberto e seu crime? A reportagem informa que para o tio de Roberto "não há como entender", e segue dizendo que "o delegado do Degran, Newton 
Fernandes, que acompanhou todas as investigações, notou frieza no criminoso e se disse estarrecido". Seu crime estarrecedor faz de Roberto uma pessoa ininteligível, mesmo para um parente próximo, e atesta sua anormalidade. Esta anormalidade deve estar relacionada com a frieza, característica notada por uma eminente autoridade policial. A legenda de uma das fotos que ilustra a reportagem afirma que "Ao saber dos detalhes do crime, os vizinhos perseguem a viatura que conduzia Roberto aos gritos de "lincha"”, e esta situação é reafirmada no texto, logo após o informe sobre a declaração de Newton Fernandes. Roberto não é apenas anormal e ininteligivel. Sua frieza torna-o odioso.

Esta primeira reportagem sobre o caso apresenta já os sulcos principais por onde escoará, ao longo dos seis anos seguintes, o discurso jornalístico sobre Roberto e seu crime. Impossível aplainar este terreno. Para buscar compreender a construção deste discurso, seus rumos e suas conseqüências, será preciso reencontrar a lisa planície que o antecedeu, será preciso imaginar as pressões que a sulcaram. É preciso retroceder um dia, focar o repórter no momento de seu encontro com a notícia. Evidentemente, não há registro preciso deste momento. Mas o processo judicial traz numerosos depoimentos sobre este dia catastrófico, suficientes para tornar recuperável uma parcela importante de seu desenrolar. O esquema abaixo apresenta os marcos mais importantes deste dia. Todos os horários indicados são aproximados, levando-se em conta os depoimentos majoritários das testemunhas ou um termo médio entre eles. 


\section{6 de janeiro de 1985}

3:00h - Mário, Karin, Paulo, Cristina e André são mortos.

6:00h - O Gol, de propriedade de Mário, é estacionado próximo ao cemitério de Congonhas, tendo em seu bagageiro os cinco cadáveres cobertos com uma manta.

7:45h - A polícia, acionada por um morador das imediações, chega ao local. Pelo menos um repórter (Cícero Carlos Bucci, da equipe de Afanásio Jazadzi na rádio Capital) chega quase ao mesmo tempo que a polícia.

8:00h - Sendo localizada, no interior do veículo, uma conta telefônica da família, um soldado PM (Natanael) telefona para a residência e fala com Roberto (diz-lhe que sua família sofreu um acidente, mas está bem), pedindo-lhe para aguardar a viatura da PM em sua casa.

8:30h - Uma viatura da PM apanha Roberto em sua casa, a fim de levá-lo ao local de encontro dos cadáveres para reconhecimento. Antes, porém, por sugestão de um policial, apanham dois amigos de Roberto (Jaime e Oscar) para acompanhá-lo, e pedem a Oscar que conte a Roberto que sua família está morta. Também por sugestão de um policial, param em uma farmácia para que seja ministrado um calmante a Roberto, pelo qual o vendedor não cobra.

10:00h - Roberto chega ao local de encontro dos cadáveres, mas mantém-se a distância. No local encontram-se policiais civis e militares, e vários repórteres. Parentes e amigos da namorada de Roberto também comparecem ao local. José Barbosa informa à polícia ter visto quando o Gol foi estacionado ali.

11:00h - Todos, policiais, repórteres e conhecidos, rumam para a casa da família, que estava sendo preservada por policiais militares desde 
às 8:30h, quando Roberto saiu em companhia dos policiais. José Barbosa também segue para a casa, levado como testemunha pelos policiais. Iniciase a perícia na residência. Roberto fica na casa de uma vizinha. Na frente da casa aglomera-se uma pequena multidão. Delegados e policiais técnicos encontram evidências que apontam Roberto como autor do crime.

12:00h - Roberto é chamado para sua casa, e aí permanece isolado dentro de uma das salas onde é interrogado por diversos delegados de polícia. Fora, circula o boato de que seria ele o autor do crime.

Das 12 às 16:00h - Muitas pessoas circulam pela casa (exceto na sala onde estavam Roberto e pelo menos um delegado), entre elas parentes e amigos da família, policiais e repórteres. Os depoimentos são contraditórios mas descrevem, todos, uma situação tumultuada no interior da residência, no quintal e nas imediações.

16:00h - Roberto confessa o crime, recebe voz de prisão, e a imprensa tem acesso a ele.

17:30h - Roberto é levado para a delegacia seccional do Degran. Na saída da casa, populares ameaçam linchá-lo.

Das 17:30h às 3:00h do dia 7JAN85 - Na delegacia, é tomado o depoimento de Roberto e das testemunhas, e lavrado o Auto de Prisão em Flagrante. $\mathrm{Na}$ assinatura deste Auto, dois repórteres figuram como testemunhas de sua leitura. $\mathrm{O}$ ambiente na delegacia também foi descrito como "tumultuado".

Os depoimentos que versam sobre este dia permitem imaginar com clareza a situação de policiais e repórteres naquela ocasião: desde o encontro dos cadáveres, logo no início do dia, tudo é confuso e perturbador. Quando a manta azul que cobria as vítimas é retirada, os policiais têm 
dificuldade já para ver quantos corpos estão no bagageiro do Gol, como fica claro no depoimento do soldado PM Natanael, em inquirição datada de 6FEV85: "QUE: abrindo a porta dianteira do veículo Gol, que estava destrancada, o depoente levantou a manta, quando então verificou que haviam quatro corpos, sendo que, posteriormente, conferindo-se melhor, ao olhar-se pelos vidros laterais verificou-se que eram cinco corpos, e não quatro;”. Mas, neste mesmo momento, já encontram-se no local repórteres e populares, esperando que a polícia transmita-lhes informações e respostas.

Também impõe-se aos policiais a tarefa de comunicar o fato ao membro sobrevivente da família. Ao falar com Roberto por telefone, o soldado Natanael, segundo conta em seu depoimento citado acima, diz-lhe que sua família sofreu um acidente, mas está tudo bem. Para Jaime e para Oscar, os policiais contam imediatamente sobre os assassinatos, mas não para Roberto. Em vez disto, pedem a Oscar que o faça, segundo o depoimento deste, no mesmo dia: "que um dos policiais que ali se encontravam chamou o depoente de lado e contou-lhe que havia ocorrido uma chacina com a família do acusado aqui presente; que Roberto encontrava-se no interior da viatura referida e os policiais pediram que o depoente contasse a ele o que havia ocorrido".

Quando policiais e repórteres chegam à casa, deparam-se com situação também confusa e perturbadora: indícios apontam Roberto como o homicida; o rapaz que até este momento aparecia a todos como vítima de uma desgraça passa a ser visto como autor da chacina familiar. Isto é simultâneo ao descortinar-se, para os presentes, de mais uma cena mórbida. Segundo o depoimento prestado em 18FEV86 pelo delegado Jorge, ele dirigiu-se à casa em companhia do delegado chefe do Degran, Newton Fernandes, e "lá constatamos que o crime efetivamente havia sido 
cometido ali pois a garagem e as escadarias estavam recém lavadas, mas havia muito sangue e também odor de sangue fresco". O delegado Ismael, em seu Relatório do Inquérito Policial concluído em 16JAN85, descreve o interior da casa, no momento da chegada dos policiais para as averiguações, como "um quadro dantesco de sangue e violência". Este contato inicial dos policiais com o interior da casa, com os vestígios do crime e com os indícios de sua autoria é concomitante com a aglomeração e assédio de repórteres e de populares curiosos no local.

Os depoimentos sobre as horas seguintes, até a prisão de Roberto, revelam a desorientação de todos os presentes, especialmente dos policiais. É notável como as testemunhas são unanimemente incapazes de precisar a hora de cada fato ocorrido ao longo desta tarde. Aliás, o único horário que cada um sabe precisar é o de sua própria chegada ao local da ocorrência; a partir deste momento, parece que todos perderam a noção do tempo. As testemunhas usam expressões vagas, como meio da tarde, quando ainda era dia, manhã, ou, quando informam um horário determinado, contradizem-se entre si.

Também há disparidades nas descrições dos fatos que ocorrem em cada lugar da casa, ao longo do dia. É especialmente difícil determinar quem tinha acesso a cada cômodo da casa, nos momentos importantes das investigações. Quando o delegado Ismael depõe, em 17OUT85 na condição de testemunha de acusação, perante o juiz de instrução da causa, suas declarações apresentam-se confusas. Sobre a sala onde permaneceu com Roberto até que este confessasse o crime, ele primeiro afirma: "Durante este período eu interrogava o réu e as vezes saía da sala para atender a imprensa, que até então não tinha acesso a casa", e que depois de obter dele a confissão, estando só, tratou de chamar "o Dr. [Jorge] e outras 
pessoas, como o Dr. [Paschoal], como também o Dr. Newton Fernandes sendo que diante de todos o réu assumiu a autoria dos fatos, (...) Nesse momento o réu recebeu 'voz de prisão', formalmente, do Dr. [Jorge]. Nesse momento a imprensa foi admitida naquela sala, quando então o réu foi apenas visto pela imprensa, uma vez que não foi permitido que se o entrevistasse". Porém, diante das perguntas do promotor (aparentemente interessado em verificar denúncias feitas anteriormente por Roberto sobre ter sido coagido a confessar mediante agressões e ameaças das autoridades policiais), afirma que durante todo o período anterior à confissão "eu somente fiquei a sós com o réu de 'conversa', mas não de 'vista', pois havia pessoas a toda a volta, tanto policiais como da imprensa. O réu também via essas pessoas e 'se sentia incomodado'. Até este momento o réu não havia confessado. É certo que nesse momento, era somente esta sala interior, digo, inferior, que não tinha o acesso livre para quem quisesse entrar. No entanto, os demais aposentos, inclusive os superiores, eram acessíveis aos presentes. Quando eu cheguei a casa do réu (às 13 h, segundo o início de seu depoimento), os objetos apreendidos já haviam sido guardados, ou melhor, os objetos apreendidos já estavam sob guarda da polícia. Em nenhum momento, vi esses objetos na parte inferior da casa, especialmente sobre o sofá", e depois: "assim que o réu admitiu os fatos diante do Dr. [Jorge] e recebeu a voz de prisão, foi o réu entrevistado por cinco ou seis repórteres, quando então o réu confirmou os fatos, o que foi inclusive gravado mecanicamente". Nesta mesma audiência, outras testemunhas são inquiridas. Judite afirma que quando entrou na casa, a pedido do delegado Ismael (por volta das $15 \mathrm{~h}$, segundo o depoimento deste), notou que "em seguida, lá entrou bastante gente, inclusive a imprensa". Irene, tia de Judite, afirma ter chegado à casa as 16h, "onde deparei com muitas pessoas na rua, bem como dentro da casa. Eu lá entrei, e falei apenas com meus sobrinhos Ricardo e Orlando. Nesse 
momento eu não vi o réu. Nesse momento eu não ouvi qualquer versão sobre a autoria dos crimes, contudo, vi a mesma calça branca com detalhe colorido no bolso, que estava sendo usada pelo réu na noite de sábado, calça essa manchada de sangue. Essa calça estava exposta sobre um sofá, juntamente com uma faca de pão, um outro facão grande, e um par de tênis, um revólver, uma camisa azul forte. A faca não serrilhada apresentava sangue, como também no tênis", e depois das perguntas do defensor-curador: "aquelas peças que descrevi, estavam expostas sobre um sofá, em tal posição, que era o que se via primeiro ao se entrar na sala". Em 20DEZ85, inquirido em audiência, Oscar, amigo que acompanhou Roberto ao local do encontro dos cadáveres, afirma que quando entrou na casa chamado pelos policiais (pouco depois de Judite, por volta das $15 \mathrm{~h}$ ), "no interior da casa já havia repórteres (...) na parte de baixo da casa vi um revólver e duas facas 'tipo facão', manchadas de sangue. Vi também um tênis 'e uma calça branca, também manchados de sangue,". Quando das perguntas do promotor, respondeu que: "quando eu entrei na casa do réu, na manhã do domingo, como já disse, observei que a perícia técnica já havia sido feita e que as armas e roupas que mencionei estavam dispostas, digo, expostas sobre um sofá, quando então eram filmadas e fotografadas pelos repórteres, sendo que ninguém as tocava".

Evidentemente, a situação era confusa, e todos, em maior ou menor grau, davam sinais de desorientação. Entretanto, todos, especialmente os policiais, deviam seguir fazendo seu trabalho.

O laudo do Exame em Local de Homicídio, realizado pela polícia científica neste dia, mas cujo relato foi concluído e apresentado apenas no dia 14JAN85, utiliza uma linguagem reta, precisa e clara. O relato sobre as 
investigações feitas no interior da casa inicia-se pelo alerta: "cabe lembrar que o grande número de pessoas ali presente, alheias aos trabalhos periciais possam ter prejudicado a constatação de todos os vestígios e indícios em sua totalidade. No entanto, os que constam do presente trabalho julgamos ser suficientes para a devida caracterização do fato". A leitura deste laudo, isoladadamente, transmite uma impressão de extrema minúcia e objetividade. Porém, quando se o compara com o Auto de Prisão em Flagrante, redigido no mesmo dia dos exames, nota-se que o laudo apenas menciona as evidências que encontram-se arroladas já neste Auto. Torna-se evidente que havia intercâmbio de informações, hipóteses, suspeitas, entre a polícia científica e as autoridades policiais (delegados) presentes. É impossível que todos os detalhes constatáveis na residência fossem relacionáveis com a cena dos homicídios e com a conduta de Roberto. Mais provável é que peritos e autoridades tenham, com maior ou menor grau de clareza e consciência, solidarizado-se nas investigações em busca de uma versão plausível para os fatos; uma versão ordeira, compreensível pelas pessoas em geral, e que pudesse ser assimilada pelo que estes experientes policiais sabiam de situações semelhantes ${ }^{60}$. A impressão inicial causada pela leitura do laudo parece derivar muito mais do tempo que a polícia científica dispôs para elaborar seu texto e lapidar sua redação, que das condições de realização dos procedimentos de exame. Em vez da minúcia, aparece então a seleção; em vez da objetividade, aparece o esforço para ordenar logicamente os achados.

\footnotetext{
${ }^{60}$ Isto era, também, o que deles era esperado. Na edição de 8JAN85, o jornal Notícias Populares descreve a verificação da autoria dos crimes: "De início, Roberto negou a autoria do crime. Sua história seria capaz de convencer a todos, menos ao experiente delegado Paschoal..., policial dos mais astutos, com 23 anos de carreira.". Esclareço, desde já, que a atuação deste delegado não aparece no Inquérito como decisiva para a constatação da autoria; talvez isto apenas não tenha sido registrado nos autos, ou talvez esta referência derive apenas de um maior contato dele com o(s) repórter(es) deste jornal.
} 
Até certo ponto, este é um esforço bem-sucedido. Quando, no mesmo dia, Jorge, delegado que prendeu e conduziu Roberto à Delegacia Seccional, testemunha diante do delegado Ismael (o mesmo que, horas antes havia obtido a confissão de Roberto), sua fala é reta e clara, suas conclusões sobre o crime parecem bem concatenadas. Testemunha e autoridade inquiridora são, ambos, delegados de polícia, e ambos estiveram quase o dia inteiro em redor de Roberto, no local do crime. É praxe que o escrivão não anote as perguntas feitas pela autoridade à testemunha, registrando apenas a resposta desta. Entretanto, pela leitura do depoimento fica quase sempre claro o momento e o teor da pergunta que motivou cada resposta. No caso deste testemunho, nota-se que o delegado Jorge falou livremente, sem perguntas por parte de Ismael. Apenas no final do depoimento, uma afirmação desconexa com o tema que vinha sendo desenvolvido sugere ter sido questionado sobre sua impressão a respeito de Roberto. Suas palavras: "QUE O DEPOENTE pode notar em conversa com o acusado presente que se trata de um rapaz visivelmente de bons princípios, desconhecendo o depoente qualquer ato de anormalidade de sua personalidade, confessou o crime com detalhes e em momento algum demonstrou sequer uma emoção pelo seu gesto. Nada mais disse e nem the foi perguntado".

Entretanto, o mesmo delegado Jorge, depondo como testemunha de acusação perante o juiz de instrução da causa, em 18FEV86, apresenta uma versão bem menos clara e encadeada das investigações realizadas e das conclusões daquele dia. Isto pode relacionar-se com o intervalo de mais de um ano entre os dois depoimentos, mas também com o fato de que o juiz não estivera presente naquelas diligências. Aparentemente, o juiz interrompe-o várias vezes, a pedir-lhe explicações e ratificações sobre o que acaba de dizer. Quando relata o curso da investigações e interrogatórios efetuados na casa, afirma que "o ambiente estava 'meio 
tumultuado', pela presença de repórteres e jornalistas que a tudo assistiam, uma vez que as investigações já haviam sido encerradas. Assim interrogado, o réu inicialmente negou os fatos". Sobre o ambiente na delegacia, onde era lavrado o Auto de Prisão em Flagrante, no momento em que Roberto é apresentado ao Sr. José Barbosa (que presenciou quando o Gol foi estacionado no local de encontro dos cadáveres) para reconhecimento diz: "devo esclarecer que no momento do reconhecimento 'o tumulto era grande', na delegacia de polícia, mas não atrapalhando o reconhecimento" e depois de pergunta do promotor: "o tumulto a que fiz referência, ainda agora, ocorria fora das dependências do Cartório, a partir 'do corredor'”. E adiante, respondendo ao defensor: “durante os trabalhos desenrolados na Delegacia de Polícia, o delegado oficiante (Bel. Ismael) teve dificuldade na condução dos trabalhos, em razão dos tumultos a que já fiz referência”.

É notável que estas três afirmações sobre os tumultos na delegacia seguem de perto as declarações que ressaltam a lisura das diligências efetuadas: “...se procedeu ao reconhecimento 'observadas as regras legais'...”, e “...eu prendi o acusado em flagrante, em face de sua confissão e levando em consideração, também, as provas materiais e testemunhais". Cumpre informar que estas situações abordadas, a confissão, o reconhecimento pela testemunha e a prisão em flagrante delito, são questionadas em sua retidão legal durante o processo. A menção ao "tumulto" parece servir como justificativa para eventuais imperfeições nos procedimentos adotados (claro que nisto apenas são abarcados pequenos deslizes nas formalidades prescritas para os procedimentos, não a inadmissível coação do suspeito para que confessasse), mas principalmente parece servir como garantia da atitude correta dos policiais em presença de pessoas alheias à polícia. Especialmente a presença da imprensa é invocada como garantia da atuação irrepreensível dos policiais, como neste mesmo 
depoimento do delegado Jorge: "os fatos a partir do encontro dos cadáveres, foram presenciados por vários repórteres e fotógrafos de vários jornais e emissoras de rádio e televisão, como o Jornal da Tarde, O Estado, a Folha da Tarde, a Jovem Pan e a rádio Capital”, ou outro, do delegado Ismael, em 17OUT85: "não sei dizer se houve qualquer violência (coagindo o réu a confessar os crimes) antes da minha chegada (à casa), mas acredito que não tenha havido porque a imprensa estava presente".

Estes depoimentos permitem compreender que, para os policiais, os "tumultos" representaram algo além de um empecilho ao seu trabalho: representaram também uma "platéia" que exigia, fiscalizava e sustentava seu desempenho no papel da polícia. A presença de populares e repórteres, cobrando dos policiais respostas sobre os fatos, parece ter servido como estímulo para que estes continuassem seu trabalho, mesmo em condições repulsivas. Isto é notável, principalmente, com relação à imprensa: na presteza com que Ismael saía da sala onde interrogava Roberto, para atender a imprensa; na liberação do acesso à residência aos repórteres, tão logo foram concluídos (talvez antes) os exames da polícia científica; na exposição das provas materiais para que a imprensa pudesse filmá-las e fotografá-las; no convite aos repórteres para que assistissem à confissão do réu junto com as autoridades policiais, como depois, na delegacia, para que assistissem a leitura do Auto de Prisão em Flagrante. Torna-se evidente a atitude ambivalente da polícia com relação à imprensa, reclamando às vezes de sua interferência no trabalho policial, mas ao mesmo tempo franqueando-lhe o acesso ao local deste trabalho, quando possuía autoridade e motivos razoáveis, talvez até imperativos, para impedi-lo naquele momento. 
Esta atitude ambivalente revela o estabelecimento de um laço de solidariedade entre policiais e repórteres que, embora permaneçam relativamente discriminados enquanto grupos profissionais, aliam-se no enfrentamento daquela situação desafiadora. As pessoas presentes, por suas relações com os fatos, agrupavam-se enquanto policiais, imprensa, "interessados" (parentes e amigos de Roberto e/ou de sua família) e "curiosos" (moradores e trabalhadores das imediações, inclusive o Sr. José Barbosa). Já nos primeiros momentos da investigação, parte dos interessados e dos curiosos são destacados pela polícia como "testemunhas". Destas, algumas passam em seguida a figurar como "suspeitos" (Roberto, Adriano, Orlando).

Este agrupamento, ao mesmo tempo que resulta do trabalho da polícia, também o orienta. A atitude de cada policial em relação a cada um dos presentes, bem como a resposta de cada um à polícia, passa a pautar-se por este enquadramento. É parte essencial do papel da polícia discriminar estes grupos, e operar com base nesta discriminação. Desde seu primeiro contato com a ocorrência, o policial é questionado pelos demais, principalmente pela imprensa, sobre a natureza e motivos dos fatos, sobre os suspeitos, sobre as pistas e testemunhas. Neste sentido, a imprensa funciona quase como um "oponente", mas é preciso ressaltar o aspecto confortador desta oposição: a todo momento sua demanda aos policiais pelas informações e respostas sobre a ocorrência confirma o papel destes, e reforça sua atuação.

Desempenhar satisfatoriamente o papel policial significa responder estas questões o mais brevemente possível. Apenas isto já torna compreensível a urgência que a polícia demonstra em informar a imprensa de cada indício encontrado, mesmo antes de poder compor um quadro minimamente abrangente dos fatos. Mas esta urgência deve encontrar 
explicação também nas emoções experimentadas pelos policiais expostos àquela situação. Em situações semelhantes, nota-se que a maioria das pessoas mostra-se compelida a pronunciar algo sobre o fato, mesmo que seja apenas uma interjeição de horror ou piedade. Boa parte delas inclina-se a conjecturar motivos, explicações, detalhes ou suspeitos. Compreendo isto como uma tentativa de evitar, ou de dissipar, a angústia suscitada pelo encontro com o estranho, com algo que escapa às categorias familiares ao sujeito, à sua experiência cotidiana, confrontando-o com os limites de seu conhecimento e de sua experiência.

Não podemos pensar senão com o conhecimento e experiência de que dispomos. O estranho é para nós, a rigor, imponderável. Mas também não podemos estar serenos diante daquilo que não podemos pensar, e por isto geralmente tentamos assimilar o estranho ao conhecido. Operação delicada, que por si é incapaz de elidir nossa angústia; sua eficácia reside na confirmação de sua validade por uma outra pessoa, resgatando para nós a realidade de um mundo compreensível. Por isto precisamos falar com alguém, compartilhar nossas ponderações sobre o acontecimento.

Naturalmente, naquela ocorrência, cada policial podia contar com a solidariedade e coesão de seu próprio grupo, com a sustentação mútua de seus papéis dentro deste grupo e com a confirmação destes papéis na atitude de todos os presentes. Mas, a cada momento, impunha-se a necessidade de confirmar o ponderado com a pessoa ao lado. Naturalmente, também, naquela situação, os repórteres apresentavam-se para os policiais como as pessoas mais confiáveis para este compartilhar. Todos os demais aparecem para a Polícia, quase por dever de ofício, como suspeitos de participação naquele acontecimento estranho. Policiais e Imprensa têm seguramente apenas uma relação profissional com os fatos. Além disso, compartilham já o mesmo jargão, talvez alguns dentre eles 
tenham experiências comuns no atendimento de outras ocorrências, e seguramente muitos já se conheciam dos plantões nas delegacias. Tudo isto contribui para que, mesmo em meio à multidão e ao tumulto, policiais e repórteres busquem proximidade, falem entre si, troquem informações, impressões e hipóteses sobre o caso.

Muitas testemunhas mencionaram os boatos sobre Roberto ser o autor dos crimes, que começaram a circular horas antes do término das investigações. O jornalista Cícero Carlos Bucci, em depoimento prestado em 6FEV86, ao delegado Araújo, titular do Distrito Policial da área de encontro dos cadáveres, afirma "QUE, foi um dos primeiros a chegar ao local (de encontro dos cadáveres), e presenciou quando o filho da família chacinada chegava; QUE pode notar que o jovem, ao chegar ao local, não manifestou emoções normais de uma pessoa que tivesse visto toda a família chacinada, pois sua reação fisionômica foi de tranquilidade, como se já houvesse visto tal quadro anteriormente, fato que despertou a suspeita das pessoas presentes no local; QUE, posteriormente, em vista de tal comportamento, os policiais rumaram para a casa das vítimas a fim de localizar a chave do veículo que não estava na ignição e proceder a outras investigações; que lá chegando, para surpresa geral, foi encontrada a chave do veículo num dos quartos". Este depoimento, mesmo admitindo que parte de seu conteúdo seja resultante de elaborações posteriores aos acontecimentos daquele dia, revela que este repórter presumia-se informado das suspeitas e intenções dos policiais à medida que estas se configuravam, como se fôra um deles. Certamente não estava de todo desautorizado a sentir-se assim, visto que estava sempre presente nos locais das diligências policiais. Na tentativa frustrada de reconstituição do crime, em 4FEV85, é mencionado como uma das "testemunhas convidadas para $o$ ato", e assina o respectivo Auto de Reconstituição de Crime, quando o acesso a este ato foi vedado aos demais jornalistas, segundo informou o 
jornal Notícias Populares, em sua edição de 5FEV85: “O delegado Ismael não permitiu que os jornalistas acompanhassem a reconstituição. 'Trata-se de um local privado' - falou o delegado. 'E eu espero que vocês colaborem. Do contrário será impossível reconstituir o crime”.”. Aliás, o próprio depoimento de Bucci, citado acima, ocorreu na fase de Instrução do Juízo por requerimento do promotor, em razão deste jornalista haver presenciado a confissão feita por Roberto, em sua casa. Tudo isto demonstra uma relação bem estreita entre jornalistas e policiais, inclusive sugerindo tratamentos preferenciais com base em vínculos de camaradagem.

Estes apontamentos pretendem esclarecer um dos motivos para que o depoimento desse jornalista - como de resto, o discurso jornalístico como um todo - reverbere os testemunhos sobre o comportamento de Roberto naquele dia, conforme foram registrados nos autos do Inquérito Policial: "QUE, positivou-se também que o acusado presente após ter deixado o veículo e cadáveres naquele local, saiu tranquilamente do local"(depoimento do delegado Jorge, em 6JAN85, no Auto de Prisão em Flagrante); "QUE, o depoente viu então descer do veículo uma pessoa do sexo masculino, jovem branco (...), QUE o depoente, viu claramente quando o jovem acima mencionado fechou a porta do veículo e com um molho de chaves na mão deixou o local, a pé, calmamente, em direção a saída da rua" (depoimento prestado pelo Sr. José Barbosa, no mesmo Auto); "QUE Roberto encontrava-se no interior da viatura referida e os policiais pediram que o depoente contasse a ele o que havia ocorrido (refere-se à morte dos familiares de Roberto); que o depoente entrou na viatura e conversando com o acusado aqui presente, sem rodeios contoulhe o ocorrido; que Roberto não demonstrou qualquer surpresa, ou 
emoção, mostrando-se totalmente frio, chorando um pouco, sem perder o controle emocional" (depoimento de Oscar, no mesmo Auto); ou ainda: "QUE, no local onde estavam abandonados os corpos, Roberto... não quis se aproximar, permanecendo a uma distância de uns trinta metros, demonstrando nervosismo, e querendo chorar" (depoimento do soldado PM Donizeti, em 5FEV85); "QUE pelo telefone Roberto demonstrou nervosismo.(...) Que Roberto mandou que o depoente entrasse $e$ o depoente entrou (...) (na sala da casa de Roberto, quando foi buscá-lo para conduzi-lo ao local de encontro dos cadáveres)"QUE Roberto estava nervoso e solicitou ao depoente que fizesse uso do telefone na sala (para contactar Ricardo, amigo de Roberto e irmão de Judite. Depoimentos do soldado PM Natanael, em 6FEV85); "Que da casa de Roberto até a casa do cunhado de Roberto, este mostrava-se chocado, muito nervoso, demonstrando não acreditar no que havia acontecido; que somente após darem a verdadeira notícia ao depoente e ao cunhado de Roberto, foi que os policiais narraram os fatos verdadeiros a Roberto, ou seja, de que a família do mesmo havia sido assassinada" (Depoimento de Jaime, que acompanhou Roberto ao local de encontro dos cadáveres, prestado em 22FEV85); "QUE Roberto não quis se aproximar do carro Gol, onde estavam os corpos e a certa distância chorou um pouquinho; QUE o depoente foi falar com Roberto, que mostrava-se nervoso" (depoimento de Araújo, o primeiro delegado a chegar no local de encontro dos cadáveres. Prestado em 22FEV85). Todos os grifos em negrito são meus.

Será preciso notar que durante o Inquérito Policial foram ouvidas, ao todo, 29 testemunhas, sempre sob a presidência do delegado Ismael. Tudo indica que, como é costume acontecer nestas ocasiões, Ismael inquiria a testemunha sobre os aspectos que visava esclarecer, ouvia e interpretava suas respostas, formulava mentalmente a redação destas respostas e ditava ao escrivão o que deveria ser registrado; entre outras 
observações, a linguagem empregada no depoimento de José Barbosa, improvável para um ajudante geral na construção civil, confirma isto.

É notável que estes registros tragam quase tão somente descrições sobre a tranqüilidade ou o nervosismo de Roberto. Penso que Ismael possa ter reduzido a diversidade das descrições apresentadas pelas testemunhas ouvidas a estas duas categorias, por conformarem-se mais facilmente ao que era esperado de Roberto em sua condição de assassino da própria família, segundo o que é "conhecido", "sabido". O nervosismo coaduna-se com a idéia de criminoso, enquanto a tranqüilidade após o crime, supostamente ligada à frieza, coaduna-se com a idéia de perversão ou loucura. Quanto às descrições recalcitrantes a esta redução, parece que as perguntas seguintes procuraram desqualificar. Quando Jaime afirma que Roberto mostrava-se chocado, logo em seguida esclarece, provavelmente em resposta a uma pergunta do delegado, que neste momento ele ainda não havia sido informado pelos policiais de que seus parentes estavam mortos, ficando sugerido que seu choque era simulado. Desacredita-se a descrença de Roberto na versão apresentada pelos policiais - mentirosa, sem dúvida. Mas principalmente desacredita-se que, embora fosse o autor dos crimes, Roberto pudesse estar chocado. Também quando o delegado Araújo afirma que Roberto chorou, especifica que chorou pouquinho. Talvez, se ficasse afirmado que Roberto "chorou um pouco" isto pudesse ser compreendido como uma avaliação objetiva do tempo durante o qual ele permaneceu chorando; mas o diminutivo duplica a escassez do choro: ele é uma vez escasso, possivelmente em relação ao tempo de sua duração, e outra vez escasso, mas desta vez em relação a algo indefinido. Fica implícito que seu choro era insuficiente para aquela situação. Desacredita-se então que Roberto pudesse chorar o bastante a morte de seus parentes. 
Esta descrença na normalidade das emoções e do comportamento de Roberto é um dos mais profundos sulcos que marcaram os rumos do discurso jornalístico sobre ele e seu crime. Penso que o registro policial dos acontecimentos contribuiu significativamente para isto, e sua forma derivou, em boa medida, da situação angustiante que aqueles policiais tiveram de enfrentar. As colusões havidas entre policiais e repórteres, estes também expostos à angústia, determinaram que os discursos policial e jornalístico proclamassem em uníssono a anormalidade e a frieza de Roberto, sua torpeza e sua loucura.

Isto pode ser, em alguma medida ${ }^{61}$, verificado nos autos do processo mediante a comparação dos depoimentos acima citados com outros, de algumas destas testemunhas que foram inquiridas noutra ocasião pelo juiz da Instrução, Dr. Martins. Antes de iniciar esta comparação, cumpre esclarecer que no Auto de Prisão em Flagrante, presidido por Ismael, constam ainda, além dos citados acima, os depoimentos de Adriano, Orlando e Ricardo, mas nestes não há registros de referências ao comportamento de Roberto durante aquele dia. Diante do juiz, porém, Orlando pronunciou-se sobre isto: "O réu disse-me então, preocupado, que alguma coisa havia acontecido com seus pais, que era do conhecimento dos policiais, que não queriam contar a ele" e "o réu também estava neste local (de encontro dos corpos) e, embora não estivesse chorando, dizia, abraçado ao Oscar 'até meu irmãozinho"” e ainda "quando então eu conversei com o réu, que me dizia 'que não acreditava' e se lamentava”,

\footnotetext{
${ }^{61}$ Digo em alguma medida porque estas pessoas foram submetidas aos interrogatórios anteriores e estiveram expostas ao noticiário da imprensa, sendo esperado que seu próprio linguajar tenha acomodado-se ao linguajar de policiais e repórteres. Até porque estas pessoas também estavam angustiadas pelo acontecimento, sendo esperável que aceitassem de bom grado uma versão construída de modo a dissipar ou minimizar esta angústia.
} 
(Orlando, em 10OUT85). Também o registro do depoimento de Judite ao delegado Ismael não faz referência ao tema, mas ela afirma, diante do juiz: "A primeira vez que vi o réu (no dia do crime), estava ele chegando a casa das vítimas, levado por meus irmãos. Não lembro o que me disse o réu nessa ocasião. O réu se mostrava um pouco nervoso e 'meio' abatido" (Judite, em 17OUT85). Outras testemunhas falaram sobre o tema em ambos os interrogatórios, e será preciso ler o que disseram em presença do juiz: “...em direção ao local onde estavam os corpos (...) paramos em uma farmácia, quando então o réu tomou um calmante, pois estava muito nervoso. Durante o trajeto (...) contei ao réu que cinco corpos haviam sido encontrados em um veículo 'Gol', corpos esses de seus familiares. Em razão disso o réu começou a chorar fazendo menção ao fato de que 'até meu irmãozinho' havia sido vítima. Registro que não notei no acusado, nesse momento, 'aquele impacto', eis que eu aguardava uma reação mais violenta(...) encontrei-me novamente com o réu, lá pelas 11:30 horas (...) ainda chorando e lamentando a morte dos parentes”. Às perguntas do promotor, respondeu: "Quando noticiei ao réu a morte de seus parentes, manteve-se ele com a cabeça baixa, chorando 'médio', não chegando a chorar convulsivamente, lamentando então que até seu irmãozinho havia morrido". Ao defensor, respondeu: "Confirmo que o conhecia 'três ou quatro' meses. Quando eu afirmei no início do depoimento que o réu reagiu 'sem aquele impacto', fiz essa afirmação não com base no comportamento anterior do réu, mas sim com base naquela que seria a minha reação em situação semelhante" (Oscar, em 20DEZ85). Também a testemunha que viu quando o Gol foi estacionado fala em presença do juiz: "havia um único ocupante que trancou o carro e foi embora, em direção contrária a que eu estava, pelo que não passou por mim”. Ao promotor, respondeu: "Eu vi que aquele indivíduo que estacionou o carro, o trancou e saiu naturalmente com a chave na mão" (José Barbosa, em 10OUT85). 
Finalmente, temos o testemunho do delegado Jorge: "Lembro-me que o réu 'chorou rapidamente' em duas oportunidades, uma antes de confessar a autoria dos fatos, e outra durante sua confissão, ainda na casa das vítimas. Eu fiquei sabendo que no dia seguinte, já no xadrez (refere-se à Casa de Detenção) o réu teria chorado bastante" (Jorge, em 10OUT85).

Em essência, talvez estes depoimentos digam basicamente o mesmo que aqueles prestados durante o Inquérito Policial. Mas é notável que, mesmo considerando-se as observações no final da página anterior (nota 61), ainda encontre-se nestes tão maior diversidade de descrições para o comportamento de Roberto naquela ocasião. Lá, Roberto era apenas tranqüilo, frio e nervoso, chorando pouquinho. Aqui, Roberto aparece nervoso, preocupado, perplexo, lamentoso, abatido, cabisbaixo e choroso. Aqui ele tranca o carro e sai naturalmente, sem despertar a atenção de José Barbosa. Aqui ele chora médio e chora rapidamente, chegando mesmo a apenas chorar, em vez de chorar pouquinho.

Penso que esta diferença de capacidade para ouvir e registrar o que dizem as testemunhas sobre Roberto, apresentadas pelo delegado Ismael e pelo juiz Martins, relaciona-se com o momento e ocasião em que cada um deles presidiu tais oitivas. Enquanto o juiz ouve as testemunhas meses após o crime, o delegado comparece ao local mesmo de sua ocorrência, no mesmo dia. Ele acompanha as descobertas dos indícios de autoria e é a primeira pessoa a ouvir a confissão de Roberto, depois de passar algumas horas em contato com ele. Mais que isto: são horas de contato nas quais, provavelmente, terá surgido entre eles um mínimo que seja de confiança e intimidade. Em seu depoimento em juízo, em 17OUT85, Ismael diz que “a essa altura o réu se mostrava calmo, e já me 
chamava de "Seu Ismael", demonstrando depositar confiança em mim. Estando o réu somente comigo, nesta sala, acabou admitindo a autoria dos fatos". É preciso deter-se a imaginar o ambiente que este delegado logrou criar, dentro daquela sala, para conseguir que Roberto o tratasse com tal intimidade, depositasse nele tal confiança. É preciso considerar quanto é exigido de uma pessoa, quanta aceitação, quanto interesse sincero deve dedicar ao outro, para que logre angariar sua confiança mesmo em contextos muitíssimo menos adversos que aquele. É preciso reconhecer que Ismael só poderia ter logrado conquistar esta confiança e intimidade mediante uma atitude acolhedora para com Roberto, e é preciso reconhecer que acolhimento não é algo simulável, pelo menos não inteiramente. Em suma, é preciso reconhecer que Ismael esteve em contato genuíno com Roberto durante algumas horas, e que neste contato permitiu-se aceitá-lo e acolhê-lo. Não cabe a objeção de que o delegado Ismael apenas instrumentalizava, a serviço de seu ofício, sua capacidade humana para o contato; esta capacidade exerceu-se genuinamente e apenas pôde ser útil às investigações porque mostrou-se suficiente para angariar a confiança - e daí a confissão - de Roberto. Mas, obtida a confissão, que destino Ismael poderia dar, naquele contexto, aos sentimentos despertados em seu íntimo pelo contato com Roberto? O Relatório do Inquérito Policial, que redigiu e apresentou ao Ministério Público dez dias depois, sugerem que tenha relegado ao silêncio qualquer sentimento de afeição, empatia, compreensão, solidariedade. Como os depoimentos que ele presidiu, conforme apontados acima, sugerem que tenha simplificado as descrições de seu comportamento. Algum incômodo deve ter restado, porém; dias depois do crime, Ismael admitia passar em frente e deter-se a olhar para a casa de Roberto, sem qualquer objetivo profissional (conforme a Folha de São Paulo de 10JAN85). 
Penso, ainda, que aquelas diferenças nos testemunhos sobre o comportamento de Roberto sejam evidências de que seus respectivos registros (o que inclui o sujeito, a hora e o lugar destes registros), mais que o comportamento mesmo, determinaram qual imagem de Roberto seria transmitida nos discursos policial e jornalístico. Imagem esta que exerceu influência também sobre o laudo psiquiátrico e o processo judicial, inclusive em suas conclusões e deliberações. Tal afirmação sustenta-se na observação de que as reações de Roberto no início daquele dia são relatadas apenas à noite, quando todos já estavam convictos de que ele praticara os homicídios. A despeito dos verbos e adjetivos empregados para descrever e qualificar a conduta de Roberto, transparece dos depoimentos, através da atitude de cada testemunha em relação a ele, que seu comportamento pareceu normal para os presentes pelo menos até antes dele aparecer como suspeito da autoria do crime. Os soldados PM mantêm a tranquilizadora versão sobre o "acidente sem conseqüências graves", mesmo depois de estar em contato direto com Roberto a algum tempo; preocupam-se em procurar amigos que possam transmitir-lhe a dolorosa notícia e acompanhá-lo no reconhecimento dos corpos, como também preocupam-se em providenciar-lhe o apoio de um medicamento calmante. Aliás, o soldado Natanael esteve na sala da casa por vários minutos sem notar os indícios materiais do crime, que depois todos reportaram evidentes, até ao olfato. $\mathrm{O}$ vendedor da drogaria onde Roberto foi medicado deixou de cobrar-lhe a despesa. O delegado Jorge, quando relata no Auto de Prisão em Flagrante seu contato inicial com a ocorrência, ainda no local de encontro dos cadáveres, conta: "QUE, devido ao estado traumático apresentado pelo acusado presente, no local do encontro do veículo e cadáveres, o depoente não teve oportunidade de interrogá-lo, deixando esta providência para ser feita posteriormente". 
Mesmo admitindo que Roberto estivesse fingindo todo este tempo, é forçoso reconhecer que todos o tratavam como se suas reações fossem coerentes com a situação. Até Roberto aparecer como culpado pelas mortes, todos comportaram-se em relação a ele como se seu próprio comportamento fosse normal. A "percepção" de todos quanto à anormalidade deste comportamento, sua frieza, sua incoerente tranqüilidade, a ausência do choro suficiente, tudo isto parece ser uma interpretação posterior, a serviço do enquadramento de Roberto em uma imagem pré-existente de "monstro assassino". A este procedimento de lapidação, de aparamento de arestas mediante desqualificações, seleções, deformações, quase a totalidade dos discursos posteriores sobre Roberto e seu crime irão conformar-se. Já em 8JAN85, o jornal Notícias Populares traz na capa a manchete: MONSTRO DA Z. SUL TEVE UM SONO DE ANJO.

Esta imagem consolidou-se sobre a tese de que Roberto praticara o crime por um motivo torpe: apoderar-se da herança dos pais, construída a partir do comentário de um policial com um repórter. Antes, no tópico Roberto, o assassino torpe, páginas 122 e seguintes, apontei as distorções nas falas das testemunhas que permitiram o acatamento desta tese, contra todas as evidências apuradas no Inquérito Policial ${ }^{62}$.

Mostra-se incrível a interpretação dada pelo promotor público aos depoimentos de Judite e Adriano sobre a sorveteria e as chaves dos carros. É sem fundamento sua afirmação sobre as extorsões de dinheiro. Em verdade, a alegação de torpeza na denúncia encontra seu fundamento em sua frase final: Preso em flagrante, sua preocupação maior junto às

\footnotetext{
62 É interessante notar que esta tese contradita a outra, também vitoriosa, da epilepsia condutopática: fala-se aqui de ambição e premeditação, e na outra, de abulia e ausência de premeditação do ato criminoso.
} 
Autoridades e jornalistas, era a de indagar sobre "como ficaria sua herança”.(??). Mais precisamente, encontra sua explicação no repetido sinal de interrogação, no final da frase. Não é difícil imaginar quão incompreensível soou esta pergunta aos policiais que a ouviram, como tantas outras coisas perturbadoras que presenciaram e ouviram naquele dia. Não é difícil imaginar a necessidade que sentiam de transferir à outrem todas estas coisas, como na clínica se diz que o cliente deposita sua angústia no terapeuta. Todos - policiais, repórteres, promotor, cada um a seu tempo - tiveram que dar um sentido a tal pergunta. Não admira que este sentido tenha divergido tanto do que lhe deu o próprio Roberto, quando a proferiu. Roberto queria escapar da situação na qual se encontrava, e pensava em recursos para poder sair pra longe, sair de São Paulo $^{63}$. Aliás, alguns elementos sugerem que ele sequer disse a palavra herança, mas teria perguntado sobre os negócios de seus pais, aparentemente referindo-se às coisas, objetos ou recursos materiais, financeiros.

Os policiais, entretanto, estavam preocupados em chegar rapidamente à delegacia de polícia. Naquele momento, a pergunta de Roberto era apenas um despropósito, algo a ser ignorado em favor da urgência em afastar-se da ameaça de linchamento que, inclusive, fazia periclitar a segurança dos próprios policiais. O delegado Jorge, depondo como testemunha de acusação em 10OUT85, confirma a pergunta de Roberto: "É certo que neste trajeto entre a casa das vítimas e a Delegacia de Polícia, o réu perguntou-me se teria direito à herança de seus parentes mortos. Diante desta pergunta, eu e meus colegas nada comentamos, até mesmo porque estávamos preocupados em chegar rapidamente à Delegacia de Polícia, a fim de preservar a integridade física do réu, uma

\footnotetext{
${ }^{63}$ Vide declarações de Roberto aos repórteres, no anexo I.
} 
vez que 'o povo queria lincha-lo'”. O delegado Ismael, depondo como testemunha de acusação em 17OUT85, diz que "alguns circunstantes se aproximaram do veículo gritando palavras como 'assassino', tendo eu levado um pontapé quando protegi o réu com o meu corpo".

Naquele contexto, a pergunta soou como um contra-senso: matar a família $\boldsymbol{e}$ perguntar sobre seus recursos materiais? É provável que algum dos policiais tenha retido a pergunta despropositada e, passado o momento do perigo de linchamento, tenha comentado com algum dos repórteres seu conteúdo. Para aqueles policiais, submetidos às exigências daquele dia, não era possível sustentar este enunciado até que o próprio Roberto pudesse esclarecer a intenção que havia em torno de sua pergunta. Era bastante, já, conceber que Roberto matara seus pais e irmãos. Era demasiado compreender que estivesse interessado em saber sobre o destino dos recursos materiais da família. Mesmo que, já no momento da pergunta, Roberto tivesse podido expressar sua intenção de sair pra longe daquela situação de assédio, prisão, ameaça, isto conflitava demasiado com a realidade, conforme era compreendida pelos policiais: a materialidade do crime, as provas de sua autoria, a prisão em flagrante delito, a custódia das autoridades policiais, a ameaça de linchamento... como compreender que Roberto quisesse sair pra longe?

Tudo apresentava-se inominável, imponderável, incompreensível: o rapaz normal que mata, o filho repreendido que mata a mãe, o filho que mata o pai, o irmão que mata três irmãos mais jovens, o assassino da família que pergunta dos bens. O promotor Lázaro, na Denúncia, utiliza-se de muitos adjetivos para descrever o crime: barbárie, insensatez, estupidez, selvagem, cruel, trágico, sanguinolento, odioso, aterrador, quadro aterrorizador à própria besta do apocalipse, horroroso, grotesco, brutal, horrível, além de outros referidos à Roberto e seus 
sentimentos durante os homicídios. Mas a denúncia data de 18JAN85. Nos primeiros relatos do crime, não bastaria adjetivá-lo. Era preciso, antes, enquadrá-lo num enunciado compreensível, aceitável. Primeiro, foi preciso compreendê-lo como chacina. Em seguida, foi preciso compreender a pergunta sobre os recursos materiais como pergunta sobre o direito à herança. Mas ainda era difícil sustentar o enunciado "chacina a família $\boldsymbol{e}$ pergunta sobre a herança". Seria preciso articular seus termos numa ordem razoável, convincente. Então, surge uma explicação compreensível: Roberto chacinou a família para receber a herança. 


\section{Capítulo 7:}

As confabulações psi sobre os homicidas violentos 


\section{As confabulações psi sobre os homicidas violentos.}

Enquanto compete à justiça estabelecer a verdade sobre os homicídios violentos, compete aos saberes psi estabelecer a verdade sobre o funcionamento mental do homicida. No caso de Roberto, ambos estes campos contribuíram para compor a explicação do crime. A justiça considerou-o um homicida torpe, condenando-o a 25 anos de reclusão, e isto respondia ao motivo pelo qual ele teria cometido os homicídios. A psiquiatria considerou-o epiléptico condutopata e sugeriu que fosse mantido a ferros por quanto tempo vivesse. Aparentemente, isto deveria responder à minha pergunta antiga, que esbocei no preâmbulo desta dissertação, ou seja, como Roberto tornou-se capaz de cometer aqueles homicídios cruéis, a despeito do horror que sua prática despertaria em qualquer outro ser humano. Para a psiquiatria forense, isto tornou-se possível porque Roberto era portador de um cérebro epiléptico.

Terminado o julgamento, a Folha de São Paulo publicou, em 22AGO87, uma reportagem entitulada Neurologista afirma que epilepsia de assassino da família não existe ${ }^{64}$. Foram entrevistados dois neurologistas, e suas opiniões sobre o assunto são taxativas: Carlos José Reis de Campos, Chefe do Setor de Investigações e Tratamento das Epilepsias da Escola Paulista de Medicina, disse que a epilepsia condutopática não existia em nenhum tratado do mundo inteiro, e que a terminologia empregada por Guido Arturo Palomba produziu um malefício maior que o assassinato dessa família inteira; fez sustentar sua opinião dizendo que a agressividade não é característica do paciente epiléptico e

\footnotetext{
${ }^{64}$ Reproduzida integralmente no Anexo III.
} 
que a crise agressiva é absolutamente rara. Por sua vez, Michel Pierre Lison, professor titular da Faculdade de Medicina de Ribeirão Preto (USP), apresentado pelo jornal como uma das maiores autoridades brasileiras no assunto, afirmou que a noção de periculosidade do epiléptico é muito antiga e é utilizada para tentar explicar homicídios inexplicáveis, acrescentando que um epiléptico, durante uma crise, jamais teria condições de executar o massacre de uma família inteira. Informou que durante certas crises, o indivíduo pode ficar confuso e, se for contido, pode empurrar a pessoa ou até agredi-la, mas faz isto de forma confusa, sem muita agressividade, como um bêbado. Também foi consultado o médico Isaac Sapaznikov, do New York Metropolitan Hospital, que disse nunca ter ouvido falar de epilepsia forma condutopática, mas que não descartava $a$ possibilidade de ser esta uma nova denominação da epilepsia do lóbulo límbico, na qual o paciente sofre uma descarga não apenas psicomotora, mas de todo o sistema emocional (...), não reconhece o seu nome, perde a noção de realidade e pode cometer alguns atos de violência e loucura.

Nesta ocasião, porém, estava já o laudo homologado pelo juiz e referendado pela decisão do tribunal do júri; as opiniões tardias de dois dos maiores neurologistas do país não poderiam alterar o destino de Roberto talvez por isto foram então ouvidas e publicadas. Os clamores e colusões sociais que contribuíram para que o diagnóstico feito pelo perito fosse endossado pela justiça foram tratados no tópico Roberto, o epiléptico condutopata. Mas não seria honesto inocentar assim todo o campo psi de qualquer responsabilidade na construção deste laudo. Na conceituação da epilepsia condutopática, feita por Palomba, encontram-se reverberações de uma atitude em relação aos homicidas, que graça em toda a psiquiatria e também entre os psicólogos: um esforço no sentido de encontrar uma causa biológica para a conduta homicida, geralmente relacionando esta causa com a frieza, crueldade e falta de empatia do criminoso. Seria preciso 
realizar uma leitura crítica da literatura psi sobre homicidas para apontar esta atitude, e para tentar compreender o que a motiva.

Reconhecida a impossibilidade de revisar exaustivamente todo o conhecimento que pode ser correlacionado aos homicídios violentos no campo do saber psicológico, resta selecionar para estudo alguns autores e, na ausência de critérios inquestionáveis de representatividade, fica autorizada uma escolha bastante livre. Tomarei, então, para consideração, três autores: os dois primeiros - M. Philip Feldman e Luiz Miller de Paiva representando duas importantes tendências da psicologia criminal, o behaviorismo e a psicanálise; o terceiro - o próprio Guido Arturo Palomba - representando a psiquiatria forense.

Não foi, porém, inteiramente aleatória esta escolha: quanto ao primeiro autor, seu livro Comportamento Criminoso. Uma Análise Psicológica [Felman, 1979], é obra de referência obrigatória para a criminologia. O segundo, é autor de um extenso e detalhado livro sobre tanatismo - Crime: Tanatismo [Paiva, 1981] - no qual ocupa-se longamente dos aspectos psicológicos envolvidos na criminalidade, sob o ponto de vista psicanalítico. Este foi o único trabalho em cujo índice encontrei um título específico para tratar de homicídios - Capítulo IV, título 1. Homicídio: forma de tanatismo - e unicamente este fato determinou sua eleição para representar o discurso psicanalítico sobre o assunto, sem qualquer consideração de mérito. Quanto ao terceiro, indicava-o o fato de ter sido responsável pelo diagnóstico de Roberto, mas foi selecionado também por ser figura prestigiada em seu campo, de que é testemunho a realização de milhares de laudos psiquiátricos para diversas varas criminais do país, sendo freqüente sua indicação como perito em casos de homicídios violentos de grande repercussão na imprensa; dele, será considerado trechos do livro Loucura e Crime. Cabe aqui o alerta de 
que a natureza destas fontes obriga a uma exposição um tanto longa das posições de seus autores, pois, de outra maneira, incorre-se no risco de lesar os pontos de vista focados, ou negligenciar aspectos essenciais à sua compreensão.

\section{Feldman e os componentes hereditários da personalidade.}

Feldman não trata de homicídios e homicidas, mas de comportamentos criminosos. Entretanto, como sustenta uma analogia entre os comportamentos agressivos e os comportamentos criminosos desempenhados contra a pessoa e como, de fato, nenhum homicídio pode ser cometido senão mediante uma agressão, pode-se tomar como pertinentes suas afirmações sobre a agressão. Sua análise procura identificar os fatores (com especial ênfase os ambientais) influentes sobre a aquisição, o desempenho e a manutenção dos comportamentos criminosos.

Segundo ele, são importantes para a aquisição do comportamento agressivo: o ambiente social favorável, no qual padrões culturais e subculturais determinam um esquema de reforçamento de condutas agressivas específicas; a aprendizagem associativa, quando a resposta agressiva para determinada situação é generalizada para uma outra, associada àquela mediante o processo de condicionamento clássico, seja por estimulação direta do sujeito, seja por sua exposição a um modelo; e a aprendizagem observacional, que resulta na imitação de modelos agressivos, inclusive de suas táticas gerais, respostas específicas, atitudes e valores. 
É conveniente detalhar as conclusões de Feldman sobre os principais fatores que ampliam ou restringem a eficiência dos modelos, reais (pais, colegas, figuras públicas, personagens dos noticiários, etc.) ou fictícios (personagens do cinema, situações experimentais, etc.), em promover a aquisição do comportamento agressivo. Parte deles estão ligados ao processo de modelação, como o tempo de exposição ao modelo, presença concomitante de modelos não-agressivos, a presença de um único ou de múltiplos modelos similarmente agressivos, instruções explícitas para segui-lo, etc. Outros, referem-se ao potencial do próprio modelo para exercer influência sobre o observador, e relacionam-se com sua habilidade em executar a agressão bem-sucedida, com as conseqüências de sua agressão, com o contexto de sua atuação ( por exemplo: foi previamente agredido pela vítima, ou a vítima é alguém execrável, etc.), e com seus atributos físicos e intelectuais, suas semelhanças e dessemelhanças com o observador, e o quanto detém de status e poder, absolutos ou comparativamente superiores aos do modelo não-agressivo conflitante. Outros, ainda, modulam a sensibilidade do observador, como seu condicionamento pregresso a propósito da agressividade e seu estado emocional anterior à exposição ao modelo, sua capacidade para justificar a atuação do modelo e a percepção de suas próprias possibilidades (pessoais e conjunturais) de sucesso ao imitá-lo.

Todos estes fatores, Feldman arrola fundamentando-os a partir dos resultados de estudos observacionais ou experimentais; mas em breve comentário sobre a imprensa acrescenta mais um - a perturbação psicológica - sem explanação. Segue-se o trecho aludido: "Jornais e televisão têm proporcionado modelos para a imitação de assassinos, seqüestradores de pessoas e aviões. Mas permanece exato que a arrasadora maioria dos leitores de jornal e telespectadores não pratica tais atos, o que sugere a importância de outros fatores para os que o 
fazem, tais como comportamentos ilegais anteriormente reforçados, a oportunidade disponível na situação vigente e a posse de talentos especiais, assim como a influência de grave perturbação psicológica ”[pág. 133/ grifo meu]. Nenhuma observação é feita à propósito da possibilidade inversa, ou seja, que pelo menos em alguns casos, a exposição aos modelos agressivos e eventualmente sua imitação, ou apenas a identificação imaginativa com eles, possa ter sido influente sobre o desenvolvimento de grave perturbação psicológica.

Entretanto, quando leva-se em conta a importância da autoimagem e da identidade para a preservação do equilíbrio psicológico, e o conflito resultante da adoção de um modelo contrário às normas sociais explícitas da não-violência, esta possibilidade parece bastante plausível. Se, além disso, notar-se o quanto são freqüentes os modelos agressivos que atendem aos principais requisitos de eficácia para promover no observador a identificação e imitação - os reais, porque muitas vezes as consequiências visíveis da agressão são pouco intimidadoras ou mesmo atraentes, como é o caso dos crimes impunes ou da riqueza alcançada por criminosos violentos, ou porque o modelo agressivo pode estar investido de considerável poder e prestígio social, ou ainda, pode haver uma atitude social prévia de apoio e justificativa para suas ações agressivas; os fictícios, porque são desenhados especialmente para este fim, como é o caso dos heróis para todos os gostos dos filmes violentos - então aquela possibilidade parecerá bastante provável.

$\mathrm{O}$ autor aponta como determinantes situacionais do desempenho de um comportamento agressivo "a presença de um modelo, a excitação emocional anterior, o álcool (embora haja complicações), as experiências anteriores aversivas, físicas ou verbais, a presença de estímulos agressivos, tais como uma arma, a retirada de reforços valorizados(se a 
retirada anterior levou à agressão positivamente reforçada), a frustração (idem), as ordens e instruções para agredir”. Sobre as interações entre agressor e vítima, no tópico específico em que as trata [Interação entre Agressor e Vítima, págs. 148-150], o autor conclui que predispõem ao comportamento agressivo, ou aumentam o nível da agressão, "o adversário de status inferior e o adversário com menor capacidade de revide, ou que provavelmente não revidará seja qual for sua capacidade", e a "intenção agressiva percebida do adversário" (mais que o nível real da agressão usada pelo adversário), e que provavelmente a expectativa de futuras interações diminuam a agressão manifestada entre os adversários. Estranhamente, não foi neste, mas no tópico Ordens e Instruções [págs. 145-148], que Feldman considerou a questão da proximidade do contato entre agressor e vítima como um dos determinantes situacionais do comportamento agressivo, respaldado no clássico estudo de Milgram sobre a obediência. Tomando por base uma observação deste autor, aponta a possibilidade de haverem pessoas capazes de cumprir ordens para a agressão embora sintam-se subjetivamente aflitas diante do sofrimento da vítima, e pessoas para as quais "não há conflito" nesta situação. Embora aí esta afirmação, que contradita as posições explícitas do autor opostas às teorias da coerência da personalidade, tenha estado diluída, a idéia tipológica subjacente resulta reforçada ao reaparecer em outros capítulos.

Feldman afirma que a manutenção do comportamento agressivo, relacionada com a reincidência, "é fortemente controlada pelas condições de reforço vigentes, quer as do próprio agressor, quer as dos agressores observados" [modelos], considerando separadamente aspectos ligados às condições de reforço externo e de auto-reforço. Sobre o reforço externo, ressalta que a agressão pode ser seguida por conseqüências satisfatórias para o agressor, como aquisições materiais, aprovação social ou ascensão na hierarquia social, ou pela ausência de consequiências insatisfatórias, ou 
"castigo"; e que estas condições de reforço favorecem a manutenção do comportamento agressivo. Considera que a demonstração de sofrimento pela vítima pode "ter efeitos reforçadores ou inibidores, dependendo do seu nível e da medida em que [serve] como evidência de agressão bemsucedida", podendo ser "altamente tolerada se garantir que os agressores obterão recompensas".

Sobre o auto-reforço, Feldman observa que, além dos reforços materiais e sociais, é provável que "certas pessoas adquiram sistemas de auto-reforço nos quais o comportamento agressivo freqüente é fonte de grande auto-estima", e um dos modos de transmissão destes sistemas seriam os modelos sociais para a agressão. Outros componentes do autoreforço da agressão seria a auto-excitação, que mantém a ira e é mantida por pensamentos sobre o objetivo visado - a destruição de um inimigo ou de um grupo odiado, por exemplo, e a difusão da responsabilidade, como acontece em situações grupais, que facilita justificar para si mesmo a própria conduta agressiva, discrepante da norma social da não-violência.

Finalmente, o autor faz notar a importância, para a eficácia do sistema de auto-reforço da agressão, dos "mecanismos de redução da dissonância, tais como inferiorização da vítima, negação da gravidade da dor, atribuição à vítima da culpa pelo ato agressivo e esquecimento seletivo da gravidade da aflição da vítima". Segundo ele, "atitudes anteriores contrárias à agressão podem ser também lentamente modificadas pela gradual dessensibilização da aversão anteriormente sentida, ou pela instigação a um comportamento gradualmente mais agressivo, em conjunto com a recepção de reforço positivo por tais comportamentos, assim como pelo uso bem-sucedido de mecanismos de redução da dissonância”. 
Todos estes apontamentos feitos pelo autor conduzem à conclusão de que o comportamento agressivo encontra-se basicamente sob o controle das condições ambientais, inclusive seus aspectos ligados à aquisição de um sistema de auto-reforço da agressão e à interação do agressor e vítima. E, com efeito, este parece ser seu entendimento quando, tratando de refutar a teoria da catarse para a explicação do comportamento agressivo, afirma que "os elementos-chave de uma estrutura explanatória do comportamento criminoso são os ambientes sociais adequados à aquisição, os próprios processos aquisitivos, as situações nas quais o desempenho de comportamentos criminosos, uma vez adquiridos, é mais provável, e as condições que mantém tais comportamentos".

Não obstante, alguns de seus apontamentos sugerem o reconhecimento da importância de uma interação entre fatores ambientais e biológicos no desempenho e manutenção, e especialmente na aquisição do comportamento agressivo. Por exemplo, Feldman faz notar, explicitamente, que a probabilidade de agressão bem-sucedida e positivamente reforçada, portanto com tendência a repetir-se, depende em boa medida da compleição física do agente [pág. 133]; também que as técnicas educativas agressivas dos pais, que servirão como modelo de comportamento agressivo a ser imitado pelo filho, podem ter sido "deflagradas pelos atributos biológicos da criança" que a tornam insensível às técnicas orientadas pelo amor [pág. 134].

O que ele não diz é que a mesma compleição física vantajosa do agente poderia, também, haver favorecido a identificação por semelhança com a maioria dos modelos agressivos fictícios, e isto ter desempenhado um papel na ocorrência da agressão que desencadeou o processo de reforçamento. $\mathrm{O}$ autor também não critica a constatação de que a cultura ofereça como alternativa para educar uma criança recalcitrante às técnicas 
amorosas unicamente as técnicas agressivas, como não critica a impropriedade desta nomenclatura que transmite a idéia de ser possível educar-se uma criança sem amor, apenas pela agressão.

A respeito da contribuição de fatores biológicos e ambientais para o comportamento criminoso, ele próprio sumaria sua posição, dizendo que "a abordagem cientificamente mais defensável é a interacionista, que leva em conta o comprimento da cadeia que une sucessivamente genes, enzimas, processos bioquímicos, desenvolvimento estrutural $e$ potencialidades de resposta" [pág.206].

Note-se, porém, que a cadeia sugerida por Feldman estanca um elo antes da verdadeira interação com o ambiente, quando a potencialidade de resposta converte-se em desempenho, passível de reforço, extinção ou punição. E, no entanto, ele dispunha de todos os elementos para prosseguir. No silêncio do autor, pode-se pensar que tenha tomado a personalidade, seu próximo tema, como o elo faltante desta conversão.

No capítulo Personalidade e Crime [capítulo 6, págs.207-239], o autor disseca, com o rigor próprio dos behavioristas, a teoria eysenckiana sobre as dimensões da personalidade - a extroversão (E), o neurotismo (N) e o psicotismo (P) - e suas implicações quanto ao processo de aprendizagem, que supostamente explicariam as tendências individuais para respeitar as leis ou para delinqüir.

É conveniente repassar, a largas pinceladas, a exposição desta teoria: a personalidade de um indivíduo seria estável, explicando porque uma pessoa porta-se coerentemente em diferentes situações e ocasiões, e suas principais dimensões $[\mathrm{E}, \mathrm{N}$ e $\mathrm{P}]$ seriam mensuráveis através de inventários apropriados. Escores elevados em qualquer destas dimensões apontariam indivíduos propensos à delinquiência, uma vez que a extroversão, o neurotismo e o psicotismo seriam perniciosos para a 
adequada aprendizagem da evitação de conseqüências desagradáveis mediante a abstenção de condutas socialmente reprovadas, predispondo o sujeito à aquisição de comportamentos criminosos.

Este efeito seria resultante de uma sensibilidade diferenciada (em relação à norma estatística) aos estímulos comumente utilizados nos métodos de socialização, em consequiência de condições neurológicas específicas; a extroversão associada a um nível baixo de excitação cortical, e o neurotismo a uma acentuada labilidade do sistema nervoso autônomo. Até o momento da análise de Feldman, Eysenck não havia postulado as bases neurológicas ou psicológicas do psicotismo, fazendo derivar a previsão de correlação positiva entre o nível de delitos e os escores em $\mathrm{P}$ diretamente do conteúdo dos ítens das escalas para sua mensuração. Segundo Feldman, a pessoa com alta contagem em $\mathrm{P}$ é descrita como caracterizada pelos seguintes traços: "solitário (não presta atenção nos outros); criador de casos (não se ajusta aos demais); desumano e cruel; sem sentimentos (insensivel aos problemas alheios); ávido de sensações; hostil aos demais; amante de coisas fora do comum; indiferente ao perigo; gosta de fazer de tolos os outros". E acrescenta ser tentadora a idéia de "considerar P como representando psicopatia, e não psicotismo no sentido costumeiro de comportamento psicótico"'[pág. 214]. Também não havia sido nomeado o extremo inferior da dimensão $\mathrm{P}$, enquanto considerava-se que $\mathrm{E}$ variava desde a introversão até a extroversão, e $\mathrm{N}$ desde a elevada estabilidade emocional até o elevado neurotismo. Os estudos realizados com a população em geral mostraram que $\mathrm{E}$ e $\mathrm{N}$ apresentam distribuição normal ("sino"), enquanto P distribui-se assimetricamente, com a maioria das pessoas obtendo escores baixos ("jota").

Submetendo esta teoria ao crivo dos estudos sobre personalidade, criminalidade e hereditariedade, Feldman conclui pela determinação 
genética das posições extremas em $\mathrm{E}$ e $\mathrm{N}$, e menciona evidência em favor da dupla determinação, genética e ambiental, de P elevado. É digno de nota que, a despeito das diferenças empíricas e das lacunas teóricas que discriminam $\mathrm{E}$ e $\mathrm{N}$ de $\mathrm{P}$, o autor não registra qualquer suspeita sobre esta última ser um artefato da escala usada em sua suposta mensuração em vez de compor, de fato, uma dimensão da personalidade.

Prossegue o autor em suas conclusões: "os que obtém escore elevado, especialmente em todas as três dimensões, provavelmente infringiriam regulamentos e causarão conseqüências prejudiciais aos outros a fim de alcançar os seus próprios objetivos de maneira mais ou menos coerente. Os que obtêm escore particularmente baixo em todas as três dimensões provavelmente evitariam tais comportamentos com igual coerência, exceto na mais extrema combinação de ganho potencial relativamente elevado, punição branda, ainda que surpreendido, e ampla oportunidade. A maioria, que obtém escore médio, provavelmente seria inconsistente em seus comportamentos delituosos e dependeria do padrão total de tentações e entraves situacionais" [pág. 225]. Aparentemente, não ocorreu ao autor que esta maioria pudesse ter aprendido, no ambiente social, a comportar-se de maneira coerentemente egoísta e oportunista.

Feldman faz também ressalvas quanto à suposição eysenckiana, basilar para este modelo teórico, de que a socialização (ou seja, o respeito às leis) depende do treino de evitação de conseqüências aversivas, considerando, ao contrário, que o reforçamento positivo mostra-se mais relevante que a punição para qualquer aprendizado; assim, segundo suas conclusões, aprender-se-ia positivamente tanto a não-delinqüir quanto a delinqüir. Esta constatação, levada às suas últimas consequiências, solaparia as bases da teoria eysenckiana sobre a tendência pessoal para o crime. Entretanto, Feldman restaura a mesma tese, partindo agora da suposição de 
que pessoas de elevada extroversão têm mais probabilidade de misturar-se socialmente do que as introvertidas, estando mais expostas a experiências de treinamento positivo para delinqüir. Diz o autor: "Se essa mistura social as expõe a modelos de comportamento delituoso, as pessoas de E elevado tendem mais que as de E baixo a adquirir tanto atitudes favoráveis aos delitos como comportamentos delituosos" [pág. 228]. Quanto às pessoas de elevado neurotismo, argumenta que talvez tenham também maior probabilidade de misturar-se socialmente, especialmente quando são extrovertidas, além de serem mais sensíveis aos reforços sociais, particularmente àqueles que as ajudam a enfrentar seus problemas emocionais. "Se tais reforços, diz, forem proporcionados a comportamentos delituosos, estes comportamentos poderão ser mais facilmente adquiridos "[pág.230].

Sobre o psicotismo, acata a tese eysenckiana de que possa obstar o treino de evitação quando forem utilizados os métodos sociais de indução ou de retirada do amor, posto que sua eficácia exigiria, respectivamente, o desenvolvimento de uma resposta empática à aflição de outrem ou a predisposição para sentir-se perturbado pela perda do amor, e sustenta que, neste caso, os métodos físicos de punição seriam mais apropriados; fica implícita a crença de que $\mathrm{P}$ elevado denuncia incapacidade para a empatia e ausência da necessidade de amor. Afirma, sumariamente, que "pessoas de $P$ elevado reagem mais fortemente a experiências de aprendizagem positiva referentes a atitudes e comportamentos delituosos do que as pessoas de $P$ baixo”[pág. 231], e pondera ainda que devam estar “mais expostos à aprendizagem vinda de outras pessoas, quer direta, quer vicariamente", uma vez que freqüentemente envolvem-se em comportamentos bizarros (segundo a composição das escalas de mensuração de $\mathrm{P}$ ), predominantemente de grupo (posto que $\mathrm{P}$ elevado tende a correlacionar-se positivamente com E elevado). 
Feldman abre, então, mais um tópico de ressalvas [Ambientes Sociais, pág.231-233], no qual lembra que as variáveis situacionais desempenham papel muito mais importante que as variáveis de personalidade para a ampla maioria de pessoas, que obtém escores médios em E, N e P; e faz notar que mesmo aquelas pessoas situadas nos limites superiores destas dimensões "terão menos probabilidade de adquirir comportamentos criminosos se forem usados tanto os métodos de treinamento otimamente eficazes (para a sua mistura particular de personalidade) como se for rara a exposição a experiências de aprendizagem social da delinqüência do que se os métodos forem menos que ótimos e freqüente a exposição às experiências sociais” [pág.232].

Seguem-se conclusões específicas sobre a aquisição (muito pouco acrescenta-se ao já exposto), desempenho e manutenção do comportamento criminoso, à luz da teoria. Sobre as implicações entre desempenho criminoso e psicotismo, dimensão de particular interesse para nossa discussão, Feldman conclui que as pessoas de escore elevado "talvez tenham mais probabilidade de cometer um delito do que os de P baixo quando a proximidade da vítima é grande e sua aflição evidente”[pág.235]. Quanto à manutenção, julga poder-se esperar que "pessoas de escore P elevado sejam menos sensiveis à aflição das vítimas $e$, portanto, mais inclinadas do que as de escore $P$ baixo a perpetrar repetidamente delitos nos quais a aflição da vítima esteja bem evidente. Contudo (...), os processos de redução da dissonância cognitiva ajudam os delinqüentes em geral a menosprezar a vítima [logo] a "vantagem" extra conferida por P elevado será mais evidente [na fase de aquisição] e na perpetração de delitos nos quais o sofrimento e a aflição da vítima são particularmente evidentes "[págs. 236-237]. 
O autor ainda finaliza o capítulo comentando a possibilidade de que as mensurações de $\mathrm{E}, \mathrm{N}$ e $\mathrm{P}$ reflitam conseqüências sociais e pessoais dos comportamentos criminosos, em vez de determinar seu desempenho ou manutenção. Por exemplo, peculiaridades da vida carcerária poderiam acentuar " a "falta de sentimento" e outros comportamentos representados na dimensão $P$ ", bem como uma carreira criminosa duradoura, pelo que exigiria de continuada depreciação das vítimas e negação de sua aflição [pág. 238].

A despeito de todas estas ressalvas, Feldman reconhece nas dimensões eysenckianas da personalidade a tendência "a prestar uma útil contribuição para a explicação do comportamento criminoso, porém mais com respeito à sua aquisição do que ao seu desempenho ou manutenção e muito mais no caso de escores extremos do que no de escores médios. Mesmo no que concerne à aquisição, entre os que obtêm escores extremos a personalidade é apenas parte da história; as variáveis situacionais representam ai papel significativo”[pág.239].

Em verdade, é no mínimo duvidosa a utilidade de E, N e P para a explicação da aquisição do comportamento criminoso, e isto à luz das considerações do próprio Feldman. Uma vez abandonada, como ele sugere, a premissa de que se aprende a não delinqüir mediante o treino de evitação, que seria a área de aprendizagem afetada pelas singularidades neurológicas responsáveis pela posição particular de um indivíduo nas dimensões da personalidade, a única conclusão possível, até então, é que o meio social ensinaria a delinqüir. As supostas dimensões da personalidade seriam úteis apenas para explicar a maior ou menor facilidade do indivíduo em estabelecer contatos sociais, e assim expor-se mais ou menos à aprendizagem das atitudes, valores e comportamentos modelares disponíveis na sociedade, que podem ser majoritariamente pró-sociais, anti- 
sociais ou oportunistas. Portanto, mesmo para os casos de escores extremos, teria sido melhor reconhecer nas variáveis situacionais um papel determinante, e não apenas significativo.

Cento e onze páginas de Feldman acham-se resumidas nestas poucas, acima. Tanto quanto seu conteúdo, espero ter conseguido preservar o sabor de honestidade transmitido por este texto; o esforço honesto de seu autor para compreender os fatores individuais e coletivos influentes no comportamento criminoso. Prova deste empenho é o zelo com que lembra a necessidade de considerar-se o outro pólo, sempre quando uma conclusão faz incidir a ênfase sobre um deles.

Mas compreender exige apreensão simultânea, e não apenas de ambos os fatores como também de suas relações. Embora procure esgotar as possibilidades de raciocínio sobre os dados de pesquisa disponíveis sobre o assunto, e mesmo buscando articulá-los com um modelo teórico de cunho interacionista, as análises de Feldman conduzem-no a conclusões vagas, que pouco acrescentam àquilo que se pode aprender sobre crimes pela simples leitura das notícias de um punhado deles: uma explicação abrangente jamais poderá repousar apenas sobre fatores ligados à pessoa do criminoso, nem tampouco apenas sobre fatores situacionais, próximos ou remotos.

Faltou-lhe atinar, segundo penso, com um elo verdadeiramente capaz de promover a junção entre características individuais e características do ambiente social. Feldman parece considerar, equivocadamente, que este elo seja formado pelos componentes hereditários da personalidade, uma vez que supostamente condicionariam a interpretação da situação ambiental e as possibilidades de aprendizagem de determinadas respostas a esta situação. Se Feldman entendesse a 
personalidade como unidade que integra constituição, temperamento e caráter, teria falhado em notar que ela já seria produto da interação indivíduo-ambiente. Se, como parece ser o caso, entende-a como simples conglomerado de disposições temperamentais hereditárias, falhou em notar que estas disposições não resistem incólumes à forja social.

Pode-se imaginar, por exemplo, que um indivíduo chegue ao mundo dotado inatamente de uma disposição "otimista" e de um particular interesse pelos contatos sociais (características da extroversão), mas é quase certo que este otimismo possa ser ultrapassado por situações desfavoráveis, extremas ou continuadas, e que contatos humanos altamente desagradáveis possam resultar numa insensibilidade defensiva aos reforços sociais, mais ainda porque estes contatos eram muito importantes para aquele indivíduo; ou seja: as disposições hereditárias podem influir na interpretação do mundo e nas possibilidades de aprendizagem, mas apenas até um limite que é dado pelo ambiente sócio-cultural. Além disso, é neste confronto com o meio que aquelas disposições adquirem conteúdo e sentido, através das valorações e das orientações que recebem dos agentes socializadores, potencializando sua capacidade de condicionar as interpretações e a aprendizagem do indivíduo. Portanto, persiste o problema de encontrar um elemento integrador entre aquelas tendências hereditárias, estas valorações e orientações sociais, e a conduta finalmente adquirida e desempenhada pelo indivíduo.

Um dos resultados daquele equívoco é a persistência da idéia de que características hereditárias poderiam fundar diferenças entre as pessoas não apenas quanto à probabilidade de aquisição do comportamento criminoso em geral como de cada gênero particular de crime. Resiste, subjacente, a crença em que disposições genéticas determinariam o modo como diferentes agressores experimentam as demonstrações de sofrimento 
da vítima, a despeito de todas as considerações sobre o caráter adquirido da empatia que, segundo o próprio Feldman, tem seu desenvolvimento dependente dos modelos e oportunidades de comportamento empático proporcionados pelo pais, e do afeiçoamento destes à criança [Capítulo 2, Aprendendo a não delinqüir: Experiência e Treinamento na Infância. págs. 60-96, especialmente o tópico O Papel do "Afeiçoamento", nas págs. 8384]; assim também resiste a crença de que o modelo de treino empregado pelos pais seria deflagrado pelas características genéticas da criança, e que uma destas características poderia ser a insensibilidade ao amor. Esta insensibilidade tornaria o indivíduo refratário aos métodos educativos sociais, pois ele seria indiferente tanto às ameaças de retirada do amor, que supostamente não lhe faria falta, quanto aos sinais de aflição dos agentes socializadores por sua conduta, que supostamente não o perturbariam dada a pouca estima que seria capaz de dedicar-lhes.

Portanto, a insensibilidade genética do indivíduo ao amor conduziria, de um lado, a que seus pais fossem levados ao emprego de técnicas educativas agressivas que tornar-se-iam modelos de conduta agressiva para o indivíduo; de outro lado, conduziria a que o próprio indivíduo desenvolvesse uma estima incipiente aos outros, cujo resultado seria a aprendizagem deficiente do comportamento empático. Em resumo, falhando a compreensão sobre a natureza da interação indivíduo-meio, a tentativa de explicação do comportamento tende a recair sobre as características genéticas do indivíduo, provavelmente em função da histórica dicotomia inato-adquirido, e especialmente naquilo que diz respeito aos comportamentos desviantes, sendo o agressivo um dos mais perturbadores dentre todos.

Mas é preciso acentuar a natureza subjacente desta ênfase na determinação genética da conduta desviante. Não fosse por isto, seria 
logicamente esperável que Feldman sustentasse claramente uma ligação entre aquela suposta predisposição genética à insensibilidade amorosa e o comportamento psicopático, que segundo suas conclusões, no tópico específico em que o trata [capítulo 7: Distúrbio Mental e Crime, Psicopatia, págs. 250-268], caracterizam-se pela falta de sentimentos pelos outros, particularmente pelas vítimas. Entretanto, embora essa ligação seja de fato sugerida, isto é feito de maneira difusa e reticente, sendo bem mais franco e evidente o esforço do autor em desqualificar a especificidade do comportamento psicopático em relação aos comportamentos criminosos em geral.

Não obstante, encerra o tópico lembrando a existência do rótulo médico legal "psicopata", e derivando desta existência alguma injunção à pesquisa. Transparece disto tudo uma conflitiva incerteza sobre a correção da explicação formulada, fruto da honestidade intelectual do autor, que ora pressiona-o no sentido de "apagar" as contradições daquela explicação, ora pressiona-o a incluir elementos que apontam tais contradições.

Assim, a desqualificação da psicopatia (uma afirmativa velada de sua inexistência) redimiria o autor de haver atribuído sua causa, indevidamente como ele deve intuir, à constituição genética do indivíduo, enquanto, por outro lado, a lembrança do rótulo médico-legal sublinha tanto sua existência virtual no campo social, quanto a existência de indivíduos que a realizam - os homicidas cruéis, por exemplo - e a necessidade de continuar buscando uma explicação verdadeiramente interacionista para isto. 


\section{Paiva e as origens do tanatismo.}

Será parcial a consideração do livro de Luiz Miller de Paiva, e isto por diferentes motivos: primeiro, como já foi dito, este livro foi escolhido sem qualquer consideração de mérito ou afinidade, unicamente em razão de um capítulo especialmente dedicado ao tratamento do homicídio como forma de tanatismo, o que de pronto desobriga, embora não impeça, comentar outros assuntos tratados pelo autor. Porém, e este é o segundo motivo, sua leitura revelou-se extremamente difícil, em parte por desagradar-me o estilo do autor, em parte por algumas vezes divergirem nossos pontos de vista. Naturalmente não fica eliminada a hipótese de que minhas limitações tenham contribuído mais que tudo para esta dificuldade, mas de qualquer modo torna-se temerária qualquer crítica, e tanto pior quanto mais extensa; limitar-me-ei, então, ao essencial para nosso assunto.

Há ainda uma terceira razão, creio que acima de suspeitas, para esta parcialidade: mesmo o capítulo em questão é dedicado, em boa parte, à definição da criminologia e à epidemiologia descritiva do crime (em geral); logo, uma crítica concentrada desta parte seria desinteressante tanto por seu caráter didático e genérico, afastado demais do nosso assunto, quanto porque algumas de suas discussões e todos os seus índices numéricos são, hoje, desatuais.

Sobre homicidas, especificamente, Paiva começa a pronunciar-se a partir do tópico Síndrome do núcleo amigdalóide e síndrome do desumano [pág. 206 e seguintes]. Desde o título, já é preciso notar a funda indecisão que permeia todo o texto: no título, a partícula aditiva $\boldsymbol{e}$ transmite a idéia de que serão tratadas duas síndromes distintas; o texto, porém, é 
impreciso quanto ao gênero de relação admitido entre ambas. Também pode ser útil alertar que para nossa discussão não importa muito a natureza desta(s) síndrome(s), nem se ela(s) tem (têm) qualquer realidade fora do texto, mas apenas a apreciação que Paiva faz dela(s).

De início, o autor vincula a síndrome do núcleo amigdalóide aos casos de epilepsia temporal por uma relação subordinativa, na qual a síndrome do núcleo amigdalóide compreende os casos de epilepsia temporal aos quais esteja conjugada a personalidade impulsiva agressiva. No mesmo momento, inaugura-se a indecisão apontada, como pode ser visto no trecho que segue: "O epilético temporal, ou melhor, o indivíduo com a síndrome do núcleo amigdalóide, quando levado por uma afetividade mórbida ou por estados emocionais patológicos é que comete os clássicos crimes hediondos a que nossa literatura forense se refere. É o que Derek Miller denominou de 'sindrome assassina ou do desumano'; todavia, o indivíduo impulsivo agressivo (síndrome do núcleo amigdalóide) pode não ser portador de síndrome do desumano; isto dependeria principalmente do fato social. Contudo, as nossas observações parecem ter acrescentado mais dois sinais, dentre os já assinalados por Derek Miller, tais como a positividade do EEG, principalmente quando aparece o foco temporal, e a parte psicótica da personalidade do neurótico descrito por Bion” [págs. 206-207].

Até aqui, pode-se supor que a síndrome do desumano seria uma subclasse da síndrome do núcleo amigdalóide, distinta desta por certo fato social. Mas o autor não esclarece, até o final de sua explanação sobre esta(s) síndrome(s), qual seria este fato social. Além disso, a partir do trecho citado acima, passa a empregar, ora a partícula alternativa/ adversativa ou para ligar as duas expressões: "os indivíduos portadores de síndrome do núcleo amigdalóide ou síndrome do desumano 
apresentam..."[pág.212]; ora a partícula $\boldsymbol{e}$, porém em contextos que levam a crer que se refira a uma única entidade, como no quadro Síndrome do núcleo amigdalóide e desumano: características da personalidade psicótica.[quadro 26, pág. 220]; ora a partícula $\boldsymbol{e}$, num contexto em que fica clara a referência a duas entidades separadas, como em "acreditamos... haver uma predisposição hereditária, isto é, maior carga de agressividade ou inveja inata... constituindo as síndromes do núcleo amigdalóide e do desumano, que por sua vez, dependeriam do meio ambiente para se desenvolverem "[pág.227]; ora, ainda, usando-as isolada e, aparentemente, aleatoriamente.

A meticulosidade com que procurei fazer acompanhar a forma deste discurso não é preciosismo, mas uma tentativa de perseguir o pensamento do autor quando escrevia; e esta forma apresenta os rastros da indecisão: talvez a síndrome do desumano seja distinta da síndrome do núcleo amigdalóide, e neste caso seria preciso compreender a relação entre ambas; poderia tratar-se de uma relação causal, sendo possível que um portador de epilepsia temporal tenha, certa ou freqüentemente, elevada carga inata de impulsividade, agressividade e/ou inveja, que determine ou predisponha ao desenvolvimento de uma personalidade preponderantemente psicótica; então ele estaria fadado ou inclinado a cometer um crime hediondo.

Verificando-se sempre a alternativa mais determinista proposta pelo enunciado acima, poder-se-ia prescindir de qualquer consideração dos fatores mesológicos para explicar seu crime, tornando-se irrelevante a menção de qualquer fato social: a causa do crime seria o foco epilético presente no lobo temporal do cérebro do indivíduo.

Porém, bastaria verificar-se uma das alternativas probabilísticas para impor-se novamente o problema de ponderar as causas do particular 
desdobramento daquela seqüência, que levou o sujeito a assassinar, ou a não assassinar; o que equivaleria a deslizar para a hipótese de tratar-se de uma relação contingente, na qual a síndrome do desumano apareceria como resultado da conjugação fortuita, no mesmo indivíduo, da síndrome do núcleo amigdalóide (conseqüência certa ou freqüente de ser portador de epilepsia temporal) e de uma personalidade preponderantemente psicótica cujos fatores determinantes deveriam ser buscados no ambiente.

É difícil resistir ao impulso de obturar as fissuras de um discurso, e por muito pouco podemos perdê-las de vista. Felizmente, Paiva oferece um mapa detalhado de seu percurso, no índice do livro: o tópico que está sendo tratado pertence à Epidemiologia analítica do crime (como este título está sob a rubrica de Homicídio: forma de tanatismo, deve-se compreender que crime, aqui, restringe-se a homicídios), e constitui-se por dois subítens, que seguem-se à apresentação da(s) síndrome(s), conforme já está reproduzida, acima. Estes dois sub-ítens são: Material clínico, onde o autor cita como evidência da relação entre epilepsia temporal e Síndrome do Núcleo Amigdalóide o resultado de uma pesquisa que realizou, sugerindo a associação entre impulsividade, agressividade, e disritmia temporal [Paiva, L. M. de. Amygdaloid nucleus syndrome and the dehumanization

syndrome. In "psychotherapy and psychosomatics". Ed. S. Karger. Ag. 1987], concluindo que "nos pacientes que apresentaram disritmia temporal não pudemos afirmar que os focos estariam diretamente relacionados com as lesões dos núcleos amigdalóides, porém, acreditamos na possibilidade de estarem comprometidos"[pág.208]; em seguida, apresenta o relato sobre um paciente que, alcoolizado, assassinou a tiros de revólver a mulher com quem vivia, durante uma discussão, e cujo EEG revelou disritmia temporal bilateral; e Comentários gerais, onde o autor afirma, sumariamente, que "os indivíduos portadores de Síndrome do Núcleo Amigdalóide ou Síndrome do desumano apresentam, durante o 
tratamento psicanalítico, como pudemos observar em 18 casos, as características (da) personalidade psicótica"(descrita por Bion), e esclarece, brevemente, que este conceito refere-se a um estado mental que se apresenta, num mesmo indivíduo, alternadamente com um estado de personalidade não psicótica. Em seguida, apresenta muito sucintamente os principais traços da personalidade psicótica: intolerância às frustrações e predomínio do instinto de morte. Encerra-se, assim, o tópico Síndrome do núcleo amigdalóide e síndrome do desumano.

O índice apresenta, então, uma falha na seqüência numerada, saltando de 2.3.4.2.6 para 2.5 - Índice de periculosidade, possível descuido no trabalho de edição; mesmo assim, fica claro que saiu-se do campo particular dos criminosos portadores da(s) síndrome(s), voltando-se à rubrica geral dos homicidas. Aqui apresenta-se, inequívoca, a fissura: o índice assinala, e a falha redunda, a mudança de assunto, enquanto o texto prossegue quase sem trepidar, exceto pela interposição do novo título, apresentando antecedentes pessoais e familiares provavelmente relacionados ao desenvolvimento daquela(s) síndrome(s), resumidos no quadro 25 - Síndrome do núcleo amigdalóide e desumanização: antecedentes pessoais e familiares [pág. 220], no qual figuram, literalmente, como antecedentes pessoais: "enurese, piromania, crueldade (para com os animais e amigos), ausências e EEG positivo"; e como antecedentes familiares: "pais violentos (alcoólatras), carência de afetividade (rejeição materna) ou os pais incutem o sentimento da criança de "não ser humana", EEGs podem ser positivos".

Até aqui é preciso sublinhar, primeiro, que ao admitir o conteúdo expresso no quadro, o autor parece inclinar-se a aceitar a hipótese de relação contingente entre duas síndromes distintas, posto que reconhece a influência de antecedentes não relacionáveis com a epilepsia temporal ou a 
disfunção do núcleo amigdalóide, segundo, que este reconhecimento tornase extensivo por ser extemporâneo pois, conforme assinala o índice, encontra-se agora referido aos homicidas em geral, e não apenas aos portadores da(s) síndrome(s), e terceiro, que uma ambigüidade insinua-se também no título deste quadro: o autor fala de um sujeito desumano?, de um processo de desumanização sofrido por este sujeito? ou ainda, como se depreende de um trecho da página seguinte no qual a palavra desumanização vem significar que "a pessoa assassina desumaniza totalmente (em sua mente) outras pessoas", estaria falando de um processo no qual este sujeito desumaniza as outras pessoas e por isto vê como inconseqüente sua destruição?

A resolução desta ambigüidade poderia informar sobre a decisão de Paiva quanto à natureza da(s) síndrome(s). A primeira e a terceira acepções coadunam-se com a hipótese de duas síndromes distintas, numa relação determinista na qual a síndrome do núcleo amigdalóide causa a síndrome do desumano, porém, a primeira poderia estar sugerindo uma crueldade mais radical e mais bruta, enquanto a terceira faz intervir uma elaboração desta crueldade pois, para destruir um ser humano o sujeito precisaria antes desumanizá-lo totalmente em sua mente, o que pode ser uma sugestão de que o homicida experimente um conflito ao descumprir a lei.

A segunda acepção coaduna-se melhor com a hipótese de que haveriam duas síndromes distintas, sem relação causal, e onde fatores ambientais determinariam a síndrome do desumano. O conteúdo do quadro, iluminado por esta possível acepção de seu título, dá pistas sobre qual seria o principal destes fatores: os pais incutem o sentimento da criança de não ser humana, ou seja, desumanizam o sujeito. 
Parece-me evidente que aqui o autor encontra-se emaranhado, sem que o saiba, porém, com questões relacionadas com a formação da auto-imagem do indivíduo, na interação com seus pais (os transmissores da cultura à crianca) e de como esta auto-imagem, posteriormente, poderia condicionar a conduta do sujeito e seu posicionamento frente aos preceitos ético-morais explícitos de sua cultura. Digo que não o sabe porque, em vez de seguir a senda que aqui abriu-se para a consideração simultânea de indivíduo e sociedade - único modo de apreender a decantada interação Paiva deixa-a perder-se de sua vista. Esta senda parece ter-se aberto num descuido já que sua principal pista é dada pela palavra desumanização, em lugar de desumano, talvez mero erro de edição. Mas este é exatamente o tipo de fissura do discurso que, penso, não devemos obturar; ainda que não tivéssemos aprendido as lições da psicanálise e suas aplicações na análise do discurso, no mínimo para tratar com justiça o autor: um estudioso que, como ele, dedica-se a tratar um tema em profundidade, escrevendo quatro extensos volumes, não merece ser considerado negligente com sua edição.

Adiante, ele irá retomar a questão do sentimento de desumanidade, incutido na criança pelos pais; primeiro quer encerrar, como é o costume, a consideração dos fatores biológicos da personalidade, onde está inserido o tópico em questão. Depois, ainda precisará falar, também separadamente, dos fatores mesológicos da personalidade.

Assim Sobrevém o tópico 2.6 - Conclusões sobre os fatores biológicos da personalidade. As afirmações conclusivas explícitas do autor são: "Em conclusão, achamos que o biotipo de Lombroso, como foi descrito, não corresponde à verdade. $O$ atavismo, se existe, não é por epilepsia pois, como vimos, o epilético não é mais agressivo ou criminal do que os não epiléticos; acreditamos, como sói ocorrer na maioria das psicoses endógenas, haver uma predisposição hereditária, isto é, maior 
carga de agressividade ou inveja inata (predominância do instinto de morte) constituindo as síndromes do núcleo amigdalóide e do desumano, que por sua vez, dependeriam do meio ambiente para se desenvolverem (...) A distinção entre a teoria freudiana e a lombrosiana é que naquela todos os seres humanos vivem durante toda a vida com seus instintos imorais e antissociais, e nesta o homem criminoso é distinto do resto da sociedade. Todavia, a conciliação entre estes pontos de vista está no fato de que aquele homem, nascido com maior carga de instinto de morte (agressividade destrutiva) tendo tido traumas nos períodos de molde e sofrendo má influência do ambiente social, pode tornar-se um criminoso, pois o homem(...) não é bom, nem é demônio..." [grifo meu]. E, finalizando: "A personalidade do criminoso não deve ser estudada somente sob o ponto de vista constitucional e sim de maneira gestáltica [grifo meu], isto é, valorizando tanto o fator biológico como o mesológico e principalmente salientando a importância de um superego frágil...”[pág. 227].

Manifestamente, Paiva decide-se pela existência paralela de duas síndromes, cujas origens seriam inatas e cujos desenvolvimentos dependeriam do meio. Porém, este pronunciamento sobre a interação dos fatores biológicos e mesológicos aparece enunciado na forma de uma sucessão destes fatores, como se pode ver no trecho que grifei, e não poderia ser diferente já que o deslocamento para adiante das questões que tocariam os modos concretos desta interação deixou em seu lugar apenas uma lacuna. Se a relação entre fatores enuncia-se como sucessão, em vez de ponderar suas interveniências, a idéia de causalidade impõe-se e seu peso recai inevitavelmente sobre o primeiro elo apresentado que, por viciosa tradição, costuma ser o genético. Paiva demonstra acreditar também nisto, e dever-se-ia pensar sobre o que o impediu de realizar o estudo da personalidade criminosa de maneira efetivamente gestáltica. 
Paiva ainda opera mais dois deslocamentos daquelas questões: não as tendo tratado no tópico mesmo em que surgiram [2.5 - Índice de periculosidade], ele "utiliza-se" (inadvertidamente, talvez) do próximo [2.6 - Conclusões sobre os fatores biológicos da personalidade] para lançar conceitos cujo conteúdo remete ao meio ambiente, mas que ali ficam sem definição e não são integrados às conclusões finais explícitas: período de molde, meio familiar, meio social, frustrações, ego forte, ego frágil, sentimento de injustiça, imitação social e aprendizagem social. Tratá-los aí, entre os fatores biológicos, talvez tivesse resultado na apreensão da interação entre indivíduo e sociedade, mas Paiva não o faz. Ainda o tópico seguinte [2.7 - Fatores mesológicos da personalidade], o autor os fará saltar, e apenas para ocupar-se de uma apresentação didática e superficial do conceito de personalidade, das biotipologias psicanalítica e de Karen Horney, e da escala de necessidades de Maslow.

Então, Paiva abre o tópico 2.8 - Fatores mesológicos do criminoso, por cujo título parece escapar ao campo de discussão da interação dos fatores biológicos e mesológicos da personalidade, que implica todos nós, pessoas, já que parece ter saído do campo de discussão da personalidade; agora, ele falará de criminosos. Isto sublinha-se no primeiro parágrafo, dos dois que compõem a introdução do tópico: “É fator exógeno, proveniente do meio externo, familiar e social. Este fator funciona como causa coadjuvante ou até determinante para quem delinqüa”.

O segundo parágrafo anuncia: "Para compreendermos bem a importância deste fator na espécie humana recordaremos o período crítico nos animais."[pág. 231], denunciando que persiste no autor, coercitiva, a necessidade de continuar considerando aspectos biológicos, e ele de fato 
discorre sobre estampagem, período crítico, comportamentos defensivos e agressão intra-específica, baseando-se em experimentos e observações realizados com patos, pintos, ratos, cães, peixes, carneiros, etc., etc., por oito páginas. Depois disto, sim, serão retomados aqueles conceitos lançados dois tópicos antes, aproximando novamente as adiadas questões relativas ao modo concreto da interação entre fatores biológicos e ambientais.

Contudo, como foram deslocadas para fora daquele campo de debate, está neutralizado seu potencial para solucionar o problema da interação indivíduo-sociedade, pois agora, segundo o título, fala-se apenas de fatores ambientais, causa coadjuvante ou até determinante, ou seja: em regra coadjuvante, embora excepcionalmente determinante, para quem delinqüa, ou seja: para o criminoso, não para o crime; mas este é outro descuido do autor.

Sem notar este descuido, tudo que vem depois parece dizer respeito às causas coadjuvantes (secundárias) do crime, cuja causa determinante seria, então, biológica, no sentido de genética, que é como Paiva utiliza. Como das outras vezes, o que de melhor fez Paiva foi descuidar-se, pois novamente seu lapso alerta para possíveis conclusões mais acertadas. Isto não deve ser fortuito. Ele próprio invoca sua experiência de ter "observado durante muitos anos(...) centenas de pacientes com disritmia cerebral e distúrbios de comportamento dos mais variados graus "[pág.208].

Certamente esta longa e rica experiência calou fundo em sua mente. Acredito que isto falou mais alto que os preconceitos sempre quando ele descuidou-se; por isto, prefiro tomar tudo que Paiva apresenta em seguida de outra maneira: como indícios de que, em regra, fatores familiares, sociais e genéticos coadjuvam (auxiliam-se mutuamente) para 
causar (produzir, motivar) as personalidades (de todos nós, criminosos ou não); embora excepcionalmente os fatores familiares e sociais prescindam do auxílio dos fatores genéticos para esta causação, de que são exemplos as dinâmicas e mitos que circunscrevem um "lugar da doença" familiar para o qual será designado um de seus membros, independentemente de possuir uma constituição genética saudável, e a produção social de personagens míticos, figuras fictícias sem qualquer substrato genético.

Mas Paiva o que faz, em seu texto, é traçar um quadro do desenvolvimento do indivíduo, do nascimento à idade adulta, fundamentado em sua experiência clínica mas, principalmente, nas observações e teorizações propostas pela corrente kleiniana da psicanálise. Deste quadro, julgo suficiente destacar tão somente as conclusões finais de Paiva sobre como as vicissitudes deste desenvolvimento podem estar relacionadas com o crime e o criminoso.

Em resumo, o autor considera que "a personalidade humana é muito complexa: existem fatores genéticos, tais como as alterações cromossômicas, as malformações do sistema nervoso, inveja inata etc., mas existem também fatores ambientais principalmente nos primeiros anos de vida (primeiro período de molde), fatores ambientais familiares (segundo período de molde) e fatores sociais. A nosso ver, a atitude criminosa dependeria, portanto, mais dos traumas durante o desenvolvimento da personalidade nos períodos de molde do que do ambiente social pernicioso (...) apesar do contato social, a família continua exercendo papel preponderante na formação do caráter" [tópico 2.10 - Conclusões sobre a epidemiologia descritiva e analítica do crime e do criminoso. Pág. 285].

Paiva não seguiu uma linha muito reta até chegar a esta conclusão, e é bem difícil estabelecer com segurança sua posição quanto às 
questões que aí estão envolvidas. Procurei afirmar o menos possível sobre isto, e não restou-me alternativa senão citar o próprio autor, em trechos que me pareceram particularmente expressivos; está claro que o "mosaico" assim construído apenas com a devida cautela pode ser tomado como uma apresentação de suas idéias. De qualquer modo, penso haver preservado-lhe o essencial, ou pelo menos aquilo que era mais notável.

Quanto aos dois "períodos" de molde, mencionados pelo autor, corresponderiam, respectivamente, à lactação e ao ambiente familiar desde o nascimento até o início da adolescência. Em concordância com o modelo teórico adotado, Paiva considera as relações mãe-filho preponderantes na formação da personalidade. Diz ele: "Um dos mais importantes objetos que existem é a genitora: na relação mãe-filho está a chamada relação primitiva do objeto.(...)na ausência do afeto materno, há introjeção de objetos maus (pais maus), podendo motivar, na idade adulta, sentimentos de culpa por fantasias agressivas inconscientes. A nosso ver, estas fantasias e subseqüentes culpas poderão ser consideradas como causas freqüentes de doenças mentais, inclusive de crimes e de idéias de suicídio"[pág.240/1].

Quando discorre sobre Doenças motivadas por carência afetiva [tópico 2.8.3, págs. 242-252], Paiva apresenta alguns motivos para esta carência: ausência da mãe nos primórdios da vida da criança; mãe que, mesmo presente, não atende as necessidades instintivas da criança, por insensibilidade ou desafeiçoamento; lares desfeitos; disciplina desigual, ora frouxa, ora estrita, em que um dia a criança é cumulada de afagos e no outro espancada; e ainda um último motivo que certamente é considerado muito importante pelo autor, já que sua enunciação recebe grande destaque: separa-se dos demais por espaçamento duplo e título em itálico, como se 
fosse um tópico distinto, contudo, sem que apareça assim no índice ${ }^{65}$. Trata-se de Mensagens bruxas, e a isto são dedicadas sete das dez páginas que falam das consequiências da carência afetiva - lembrando que o título do tópico é doenças motivadas pela carência afetiva.

Note-se desde já que, embora o autor não explicite isto, pode-se depreender a razão pela qual tanto espaço é dedicado à apresentação de um motivo, quando o texto pretende falar de conseqüências: é que a mensagem bruxa parece ocorrer sempre em "segunda edição", ou seja, sua ocorrência numa geração de pais é motivo de ocorrência na próxima geração (quando seus filhos forem pais), e conseqüência de sua ocorrência na geração anterior (quando estes pais eram filhos) - pois através delas falam os objetos maus introjetados.

A conceituação da mensagem bruxa, segundo a referência fornecida por Paiva, é dada por Berne, E. Transactional analysis in psychotherapy [Edit. Grove Press. N. Y. 1961. Pg. 30]: “A mensagem bruxa é uma comunicação transmitida de maneira negativa, sentida, portanto, como uma censura e condenação com poder de maldição, sempre de pais para filhos(...) A nosso ver, a mensagem bruxa é sempre inconsciente, com predomínio do instinto de morte, embora às vezes pareça estar sob influência libídica. Sob o ponto de vista analítico a mensagem bruxa é o resultado da introjeção de objetos tanáticos; o indivíduo que manda a mensagem bruxa age de acordo com os sentimentos agressivos destes objetos; outras vezes há excesso de identificação projetiva destes objetos; que tanto podem ser os pais como qualquer

\footnotetext{
${ }^{65}$ Pessoalmente, considero-o mesmo bastante importante pois remete a questões relacionadas com a formação da auto-imagem e com a designação do "lugar" ou do "papel" do indivíduo no grupo familiar, que me parecem cruciais para a compreensão da trajetória posterior deste indivíduo em meio à sociedade, além de darem ensejo à discussão das articulações entre a organização familiar restrita e o contexto social mais amplo.
} 
indivíduo, transformados em objetos bizarros [conforme Bion, W. R. Os elementos de psicanálise. Zahar. Rio. 1966], os quais tornam-se perseguidores internos por terem adquirido poder de maldição. Em nossa experiência, sentimos a mensagem bruxa pelas atitudes objetivas dos pais dizendo: "você está com o diabo no corpo"; a criança sente-se com o próprio diabo e age como tal fazendo peraltagem e tomando atitudes antissociais (...) A mensagem bruxa não se revela apenas quando os pais, não acreditando no bom que o filho possui, só enxergam o ruim, mas também pela atitude de indiferença ou mesmo pelo silêncio quando deveriam dar uma só palavra de alento, esperança ou crédito (...) A mensagem bruxa pode, nesta condição de indiferença, coincidir com o "duplo vínculo" de Bateson [Bateson, G. Doble vinculo y esquizofrenia. Edit. C. Lohlé. Buenos Aires. 1977] ou injunções contraditórias e paradoxais" [págs.245/6].

Encerrando este tópico, Paiva afirma que "a origem do desenvolvimento do caráter e da saúde mental está na rica e frutífera comunhão de infinitas formas entre mãe-filho, pais e irmãos. Fantasias inconscientes podem surgir no primeiro período de molde a serem produtoras de sentimentos agressivos ou de culpa acarretando assassinatos ou depressões e suicídios "[pág. 252], o que coaduna-se com algo dito antes: "o ego e o superego das crianças que sofreram privações graves [refere-se a crianças privadas do afeto materno, especialmente por interrupção das relações materno-filiais nos primeiros três anos de vida, mas sendo possível ampliar este entendimento para os demais motivos de carência afetiva apontados pelo autor, entre eles a mensagem bruxa] tendem a não se desenvolver suficientemente; convertem-se essas crianças em personalidades psicopáticas, sem afetividade, incapazes de deduzir as conseqüencias de seus atos ditados pelas más experiências, passam a ser as piores inimigas de si próprias e da sociedade”[pág. 244]. A última frase 
remete ao conceito de tanatismo: "chamamos de tanatismo uma entidade clínica, na qual existe um predomínio relativo do instinto de morte, levando o indivíduo a uma autodestruição aguda ou crônica e causando, invariavelmente, danos a outrem "'[pág. 19].

Da explanação inteira do tópico 2.8 - Fatores mesológicos do criminoso depreende-se que Paiva admite a seguinte ordem de relações: O tanatismo seria resultado de uma constituição genética predisponente à agressividade e inveja, e de culpa persecutória em função de fantasias inconscientes agressivas em relação aos pais, cujo agravamento depende, em boa medida, dos traumas do período de lactação (privação de afeto materno); esta constelação de fatores determinaria a introjeção dos objetos tanáticos, muitas vezes sentidos como bons.

Esclarece o autor: "o individuo não só internaliza objetos maus, porque lhe são impostos, mas também porque necessita deles e deseja governá-los. Se os pais, por um lado, são objetos maus, por outro são indispensáveis (...) daí o filho preferir internalizá-los, apesar de ruins. Como não os tolera ruins, procura idealizá-los como bons, do que resulta a internalização de objetos tanáticos, sentidos como bons(...) Assim os indivíduos, quando crianças, introjetam objetos tanáticos filicidas, como sói acontecer com delinqüentes. Quando adultos, os esconjuram, porém não ficam livres deles. Este sentimento filicida que a criança absorve dos pais, julgamos de fundamental importância na origem das idéias assassinas"'[pág. 273]. Em alguns casos, acresce-se o processo de identificação introjetiva do sujeito com estes objetos, conduzindo-o à autodestruição, por exemplo, pelo consumo de drogas, ou ao suicídio; estas seriam maneiras de atacar o objeto mau, agora internalizado. 
Entretanto, segundo o autor, as origens do tanatismo repousam sobre a capacidade (instintiva) humana de ter fantasias inconscientes, que são o corolário mental, o representante psíquico do instinto [pág. 26], e sobre a capacidade individual de "elaborar fantasias inconsciente de maneira destrutiva"[pág. 30]. Enquanto aquela primeira capacidade encontra-se presente em todo ser humano, sendo distintiva da espécie, esta última decorre de predisposições genéticas que distinguem os homens entre si, como se lê no trecho: "o homem pode nascer com o ego forte ou fraco, na dependência das suas predisposições genéticas(...); ele pode nascer com maior ou menor capacidade de inveja, que é forma de agressividade; quanto maior a inveja maior a capacidade de elaborar fantasias inconscientes de maneira destrutiva. $O$ indivíduo nascendo com ego forte apresenta melhores condições de superar as dificuldades dos períodos de molde e as vicissitudes da vida. Aquele nascido com ego frágil (...) tem dificuldade de enfrentar as frustrações próprias deste mundo, cheio de defeitos, tornando-se exageradamente revoltado contra as injustiças existentes na sociedade, tal como o delinqüente ou o criminoso portador de personalidade psicótica; estes acabam em "angústia existencial" por defeito ontogenético (ansiedade ontogênica). Há, portanto, uma segunda evolução do homo sapiens: o saber transpor a própria ignorância sobre as suas fantasias inconscientes e sobrepujar e controlar o resquício de animalidade” [págs. 30/1].

Fica implícita a crença de que a constituição genética do indivíduo não apenas determina o grau de tanatismo que irá apresentar, como o seu grau de humanidade ou, o que é dizer o mesmo, seu grau de animalidade, uma vez que, embora todos nós tenhamos sido agraciados pela primeira evolução do homo sapiens, a capacidade de ter fantasias inconscientes, nem todos nascemos dotados da capacidade de empreender a segunda, de modo a sobrepujar e controlar os resquícios de animalidade, 
ascendendo à plenitude humana. Para estes, Paiva ainda oferece a chance de compensar seu defeito ontogenético mediante a reeducação, especialmente aquela promovida pela psicanálise. Porém, este indivíduo pode sentir medo, que também é inato, de reeducar-se, e neste caso o incremento do tanatismo será inexorável [págs. 31/2]. Corroboram esta leitura inúmeros trechos do livro, inclusive a epígrafe do seu capítulo final: "Há pessoas que nascem com um rouxinol no coração e, por mais miserável que seja a gaiola, o passarinho sempre canta"[Cap. VIII: Neurose de êxito ou sucesso. Mensagens anti-bruxa e anti-tanática, pág. $353]$.

Voltando para os efeitos da privação afetiva no desenvolvimento da personalidade e na tendência ao crime, tudo quanto o autor afirmou ilumina-se agora de nova luz, ou melhor, da mesma luz que iluminava suas conclusões sobre os fatores biológicos e mesológicos da personalidade [tópicos 2.6 e 2.7]: a sequiência explicativa inteira termina por radicar-se na constituição genética do indivíduo, que condiciona sua interpretação daquilo que o ambiente familiar e o ambiente social proporciona a ele. Isto tem o poder de neutralizar as repetidas afirmações sobre a importância das relações materno-filiais e sobre a influência do ambiente familiar e social.

Restam inócuas no texto passagens como: "a sociedade pode exercer, também, a sua influência pelo exibicionismo jornalístico dos crimes; este exibicionismo atuaria no criminoso já com tendência ao crime. $O$ indivíduo tenta o crime na procura de auto-apreço e de ser assim aceito na turma (gang). A situação climática quase não tem influência sobre a criminalidade, embora certos períodos do ano (natal, por ex.) exacerbem os conflitos já existentes (similar aos depressivos) '[pág. 278], ou: "Cada um de nós avalia, a seu modo, o grau de moralidade e mesmo de criminalidade de nossa conduta, de acordo com o meio em que se 
vive"[pág. 279], ou ainda: "a conduta de um indivíduo depende mais do seu período de molde do que dos impulsos instintivos herdados. Esta influência do meio está baseada em tendências destrutivas e eróticas reforçadas pelo princípio da realidade”[pág. 288], e finalmente: “Onde quer que exista uma sociedade que admire salteadores e aprecie a sagacidade ou o destemor dos assassinos, as características desta sociedade se refletirão nos pais, mesmo quando eles próprios não forem criminosos, influenciarão os filhos ”[pág. 289].

É lastimável que o autor destroce, assim, sua própria argumentação. Mas isto não a despoja inteiramente de mérito, extensivo a Paiva por um caminho tortuoso, mas válido: aquilo mesmo que é contraditado quando tomamos globalmente o texto de Paiva, é o que pode ser reabilitado como indício de um roteiro mais adequado para buscar-se a compreensão das interações entre indivíduo e sociedade. Seu texto serve de esclarecedor exemplo, tanto de alguns dos modos como tais indícios podem obnubilar-se para o cientista, quanto de como podem resistir às armadilhas da língua, e mesmo, utilizando-se de suas ambigüidades, transparecerem através delas. Acredito que para isto contribui a posse de um conhecimento tácito sobre os labirínticos contornos daquelas interações, obtenível apenas mediante a larga experiência com seus aspectos mais complexos, em geral aqueles mais problemáticos - e nisto reside o mérito de Paiva.

\section{Palomba e a epilepsia condutopática.}

Antes de iniciar a análise de seu texto, é preciso alertar que, diferentemente de Feldman e Paiva, animados da disposição franca de 
teorizar sobre crimes e criminosos, Palomba não pretende tratar das causas do crime, nem mesmo tratar de qualquer crime ou criminoso, mas ocuparse apenas dos “(...) loucos externamente perigosos, cujos atos acabam ferindo os bens tutelados por lei (...) e das suas patologias”[pág. 19], visando, principalmente, "deixar registrado, para que outros tenham acesso, alguns casos clínicos"'[Prefácio], e secundariamente, contribuir para a divulgação da Psiquiatria Forense, especialmente entre juízes, médicos, advogados, promotores e psicólogos.

Ele informa, porém, que nos primeiro e segundo capítulos, e no início de cada um dos demais, "há a parte teórica; talvez possa servir ao leitor não especializado na matéria como introdução aos principais tipos de loucura: reúne, numa síntese, as doutrinas vigentes", mas está claro que este não é o principal propósito do trabalho. Diante da despretenciosidade com que o autor trata o conteúdo teórico de seu livro, talvez possa parecer descabida sua consideração numa dissertação acadêmica; pode ocorrer a alguém que seria mais pertinente considerar uma obra mais rigorosa.

Se não bastarem a dissipar tal objeção as credenciais de Palomba, que à época da publicação, segundo o editor, já era autor de "cerca de sete mil perícias para as diversas Varas Criminais e Cíveis da Capital e Interior do Estado de São Paulo e para vários outros Estados brasileiros", devem bastar estes argumentos: sendo composto, em sua maior parte, por laudos emitidos pelo autor em sua prática profissional, o livro reflete, com uma autenticidade que dificilmente poderia ser igualada em obras de outra natureza, o efetivo exercício da psiquiatria forense, e uma vez que interessa conhecer as respostas oferecidas por esta ciência aos casos de homicídio dos quais é chamada a ocupar-se, então dificilmente se poderia encontrar fonte mais genuína para buscá-las; e a propósito, vale notar que, embora em nenhum momento $\mathrm{o}$ autor atribua deliberadamente qualquer 
especificidade a este tipo de crime, o livro apresenta vinte e um casos clínicos, dos quais vinte tratam de homicídios, consumados ou tentados, e mesmo no único caso em que a perícia ocorreu por motivo diverso - porte de entorpecente - o réu era suspeito de, antes, haver matado o próprio pai. Aliás, a maioria dos casos relatados pertence a modalidades de homicídio que geralmente provocam grande comoção social pois pesou na escolha do autor, como ele diz no prefácio, “... as formas monstruosas como foram praticados alguns delitos". Em acréscimo, creio que possa causar alguma surpresa perceber, contrariando aquela despretensão, o quanto de sistematizações e generalizações sobre loucura e crime podem ser derivadas de seu texto, e refiro-me não às teorias adotadas pelo autor, que orientam sua escrita e assim permanecem nele subjacentes, mas ao que emerge do próprio livro.

Loucura e Crime compõe-se de catorze capítulos, sendo o primeiro dedicado à definição da loucura. Nele, Palomba opõe loucura, ou doença mental, à normalidade, e informa que a norma psiquiátrico-forense, baseada na capacidade de entendimento e de auto-determinação (razão e livre-arbítrio) parece-lhe "a mais adequada e segura para a caracterização da normalidade mental humana”[pág. 17].

O segundo capítulo apresenta uma classificação dos criminosos, em cinco tipos básicos: impetuosos, ocasionais, habituais, fronteiriços e loucos. A construção destas cinco classes atende a critérios visivelmente heterogêneos: ocasionais e habituais referem-se à freqüência com que o indivíduo delinqüe e, indiretamente, ao contexto social que propicia ocasiões para a prática e para a formação do hábito criminoso; impetuosos refere-se a uma característica do indivíduo, que teria sido determinante na prática de um crime; enquanto fronteiriços e loucos situam os indivíduos na 
linha contínua que, segundo o autor, ligaria normalidade e doença mental. Ainda, estes critérios sobrepõem-se de diversas maneiras: faltando ao indivíduo a emendabilidade típica do criminoso ocasional, ele pode tornarse habitual [pág. 22]; os três primeiros tipos seriam "normais, isto é, de indivíduos psicologicamente dentro da faixa de normalidade mental", enquanto fronteiriços e loucos pertenceriam "ao terreno do patológico" [pág. 23]; entre habituais e fronteiriços "há, em certos casos, interpenetrância de tipos, isto é, muitos habituais são fronteiriços, muitos fronteiriços são habituais"'[pág. 23]. Estas imprecisões podem ser resultado de que, como esclarece o autor, o sistema de classificação adotado, originalmente desenvolvido por Candido Motta [Motta, C.: Classificação dos Criminosos. São Paulo, Rossetti, 1925], foi adaptado "para atender ao que condiz com as nossas [de Palomba] observações”[pág. 21].

Menos visível é a ambigüidade com que estão discriminados, nesta classificação, os criminosos impetuosos e os loucos que agem por impulso momentâneo ${ }^{66}$. Sobre os primeiros, diz o autor: "Agem em curtocircuito, por amor à honra, sem premeditação, fruto de uma anestesia momentânea do senso crítico. Dentre os delitos que praticam relacionamse principalmente o crime passional, e alguns tipos de assassinatos e de agressão física. O criminoso por ímpeto, às vezes, por causa de uma simples discussão, sentindo-se ofendido, acaba por descarregar a arma(...) Não raro os jornais trazerem notícias sobre assassinatos e brigas após inexpressivos abalroamentos(...), normalmente, depois de praticado o crime, arrepende-se do que fez, e isso se deve ao fato de o psiquismo que possui ser, no seu todo, satisfatoriamente estruturado, salvo a falha do

\footnotetext{
${ }^{66}$ Adiante, quando o autor tratar especificamente da epilepsia, esta ambigüidade alcançará ainda os criminosos fronteiriços, mas por ora basta considerar os impetuosos e os loucos impulsivos.
} 
senso moral quando em face de determinada situação que o instiga"[pág. 21].

Sobre os loucos criminosos, o autor afirma serem "indivíduos com notável e permanente alteração de uma ou de várias funções da economia biopsicológica, que delinqüem”, e divide-os em dois grandes grupos: "os que agem graças a um processo lento e reflexivo e aqueles que agem por impulso momentâneo”. Nestes últimos, “(...) a deliberação do crime (...) é fruto de uma impulsão momentânea. O impulso súbito é seguido de imediata execução. $O$ ato é em curto-circuito, reação primitiva, sem motivo algum que possa justificar o tipo de atitude (...) o ato é praticado sem pensar, instantaneamente”. O paradigma da doença, para este grupo, "pode ser a epilepsia e muitas vezes a oligofrenia". Loucos criminosos de ambos os grupos, segundo o autor, quando presos “confessam o que fizeram, são indiferentes ao processo, não têm remorsos, desprezam ou são indiferentes para com as vítimas, muitas vezes mostramse satisfeitos com a ação que praticaram ”[pág. 25].

Desta exposição pode-se depreender três elementos de diferenciação entre os dois tipos: primeiro, a presença ou ausência de doença mental ou, mais especificamente, de epilepsia ou oligofrenia; segundo, o arrependimento ou o não arrependimento do sujeito; e terceiro, a existência ou não de um motivo que possa justificar sua atitude. Nem será preciso demonstrar a ineficácia deste último elemento para a discriminação pretendida pelo autor: ele próprio menciona assassinatos impetuosos cometidos por causa de uma simples discussão ou após abalroamentos inexpressivos. Quanto ao segundo, deve-se guardar cautela sobre a exatidão com que se reconhece o remorso nos homicidas. É possível sustentar, inclusive, que a atribuição de loucura ao criminoso acione tendências 
preconceituosas no sentido de invalidar os motivos de sua conduta ${ }^{67}$, e de desconhecer suas demonstrações de remorsos, conforme foi apontado anteriormente, no estudo do caso de Roberto, assim como é possível sustentar, num sentido aparentemente inverso mas em verdade complementar a este, que a atribuição de loucura ao criminoso pode ser manifestação do assombro social diante dos motivos do crime e da conduta posterior de seu autor, na medida em que estes motivos e estas condutas contrariam aquilo que é compreendido pela concepção explícita da humanidade; ou seja: é possível sustentar que a aposição do rótulo de louco, em alguns casos, mais que conseqüência da detecção da presença da doença mental no indivíduo, resulte de um concerto solidário das várias organizações institucionalmente encarregadas de formular a resposta social ao crime e ao criminoso. Portanto, ambos os elementos, motivos e arrependimento, devem ser descartados como meio inequívoco de diferenciar entre criminosos normais impetuosos e loucos criminosos impulsivos.

Restaria o primeiro elemento, a presença ou ausência de doença mental, mas isto é precisamente o que se trata de discriminar, de maneira que, levando-se em conta o que está dito imediatamente acima, este elemento estaria reduzido a uma questão de convicção na fidedignidade dos métodos diagnósticos disponíveis para a detecção da loucura. Obviamente, não caberia aqui o tratamento inteiro desta questão. Quando estiver em pauta o diagnóstico dos epilépticos criminosos será inevitável abordá-la, ainda que parcialmente. Agora, o que deve ser notado é como o contexto de suas observações vem influir sobre a classificação proposta pelo autor:

\footnotetext{
${ }^{67}$ Para ilustrar esta tendência, pode-se recordar os resultados da experiência de David L. Rosenham, cujo resumo e referências sobre as publicações são apresentados em: R. Jaccard, A Loucura. Rio de Janeiro: Zahar, 1981[capítulo 3: Linguagem e Poder: Rotulagem Psiquiátrica e Invalidação Social].
} 
Palomba é psiquiatra forense, sendo frequentemente requisitado a deliberar sobre a insanidade mental (suposta pelo juiz) de indivíduos acusados da prática de crimes extraordinários, monstruosos. Seu livro trata precisamente de casos como estes, nos quais o perito deliberou pela loucura do réu. Disto decorre a necessidade de haver uma classe para abrigar aqueles casos extraordinários nos quais a perícia deliberou pela normalidade mental do réu. Minha análise posterior pretende demonstrar que a classe dos criminosos fronteiriços, e portanto a categoria nosográfica da epilepsia forma condutopática que Palomba faz-lhe equivalente, atende a uma necessidade semelhante: acomodar os criminosos que se apresentam desconformes ao diagnóstico de loucura e cujos crimes acrescentam ao extraordinário uma nuance de monstruosidade.

Os restantes doze capítulos de Loucura e Crime recebem, nesta ordem, os títulos: os esquizofrênicos, os toxicômanos, os alcoolistas, os epilépticos, os oligofrênicos, os neuróticos, os condutopatas, os simuladores de loucura, os piromaníacos, os místicos, os parricidas, os assassinos seriais. É preciso notar que esta seriação não resulta aleatória, e a circunstância de que o autor tenha professado sua intenção de quase tão somente deixar registrado, para que outros tenham acesso, alguns casos clínicos que durante vinte anos de profissão chamaram sua atenção não justifica desconsiderar-se a importância da sistematização operada por este índice.

Se pela expressão doutrina vigente compreender-se o conjunto das proposições geralmente aceitas pelos integrantes de um campo científico, que orientam as produções deste campo servindo-lhe como referência fundamental e, portanto, obrigatória mesmo quando se trate de o contestar, então, deve-se acatar que os cinco primeiros capítulos são plenamente concordantes com a doutrina vigente na psicopatologia, que é 
praticamente unânime em classificar a loucura sob duas rubricas: a das psicoses funcionais, entre as quais se pode relacionar os esquizofrênicos, e a das psicoses associadas à patologia cerebral orgânica, agrupadas em síndromes cerebrais crônicas, entre as quais se pode relacionar os epilépticos e os oligofrênicos, e síndromes cerebrais agudas, entre as quais se pode relacionar os toxicômanos e os alcoolistas [conforme Butcher, J. N.: Psicologia do Anormal. São Paulo: Cultrix, 1975]; mas deve-se perceber que, a partir daí, o livro não se limita a reunir, numa síntese, a doutrina vigente, como apresenta-o seu autor, mas embute uma teorização particular, que merece ser analisada.

Seguem-se três capítulos cujos títulos fogem ao campo consensual da loucura. Os neuróticos não são loucos, como o próprio autor afirma, já na primeira frase do capítulo: "Neurose não é doença mental, loucura propriamente dita" [pág. 131], abstendo-se, inclusive, de registrar casos desta espécie (o capítulo, diferentemente de todos os demais, constitui-se apenas da parte teórica). Os simuladores de loucura, evidentemente, não são loucos, mas farsantes, e se algumas páginas são a eles dedicadas em Loucura e Crime, é apenas para frisar a impossibilidade de equívoco nas conclusões periciais posto que, nas palavras do autor, “... 'o louco tem aspecto de louco': há um brilho típico nos olhos do delirante, há uma postura física típica no corpo do deprimido, há uma movimentação típica nos casos de mania, há uma inflexão de voz típica para determinadas patologias, isso para falar de algumas características grosseiras, que o simulador, por mais hábil que seja, não consegue imitar"; e isto, conjugado com "o conhecimento da vida anterior do examinando, com o exame acurado da manifestação psicopatológica, com os pródromos da doença, que são indissimuláveis, fatalmente levarão o perito a um juízo de certeza”’[pág. 158]. 
Mas, entre os neuróticos e os simuladores de loucura, há os condutopatas, categoria que, logo a seguir, será considerada com maior detalhe, tanto porque este é o diagnóstico atribuído a Roberto, quanto porque é a categoria que mais atenção recebeu em Loucura e Crime. Na classificação apresentada por Palomba, estes são os criminosos fronteiriços, que vivem entre a normalidade e a loucura, o que torna curioso que entre o primeiro bloco de capítulos, dedicados aos loucos criminosos, e este, dos fronteiriços, o autor tenha intercalado os neuróticos, que são normais, quando pareceria mais natural intercalar condutopatas entre loucos e neuróticos. É igualmente curioso que os simuladores de loucura, que vem afirmar a infalibilidade de um perito atento, tenha seguido os condutopatas, antecedendo os quatro últimos capítulos, nomeadamente os piromaníacos, os místicos, os parricidas, os assassinos seriais (note-se que estes títulos já não fazem referência às categorias nosográficas da loucura, mas às peculiaridades dos crimes que ilustram o capítulo), que trazem, cada um deles, um caso exemplar da condutopatia.

Esta inusitada maneira de ordenar a apresentação dos capítulos permite dizer que o livro organiza-se em duas partes: uma que trata dos loucos criminosos em geral (capítulos III, IV, V, VI e VII); e outra que trata especificamente da condutopatia ou, como fica melhor definida pelo autor, epilepsia condutopática (capítulos IX, XI, XII, XIII e XIV). Os capítulos I e II, introdutórios, e o capítulo VI sobre os epilépticos, seriam partilhados por ambas.

Permanece incerta a necessidade que o autor sentiu de incluir os capítulos sobre neurose e sobre simuladores de loucura, tornando irresistível a insinuação de que ele deva intuir que a condutopatia situa-se a meio caminho da normalidade angustiada e conflitiva do neurótico, e da fraude oportunista do falso louco. Certo é que, tacitamente, Palomba trata a 
epilepsia condutopática não exatamente como zona fronteiriça entre a normalidade e a loucura, mas como algo bem distinto, tanto da normalidade quanto das demais formas da loucura.

Na parte teórica do capítulo VI, Palomba sumaria a história da epilepsia desde quando, na antiga Grécia, era compreendida como possessão demoníaca, até a descoberta científica de seu substrato anatomopatológico. Conta que "na Grécia de recuados tempos acreditavase que vinha o espírito de cima e abatia o indivíduo, donde o nome epilepsis: epi, o que está acima; lepsis, abater, pegar. Este espírito, sempre maligno, podia tomar o indivíduo de duas maneiras, total ou parcialmente(...) no primeiro caso era a possessão demoníaca completa; no segundo, possessão demoníaca incompleta"[Carvalhal Ribas, J. As fronteiras da Demonologia e da Psiquiatria. Edigraf, 1964. Citado por Palomba], e que "havia também um outro tipo de indivíduo votado ao diabo: era o homem ruim, muitas vezes bruxo, feiticeiro, que tinha livre trânsito pelos mundos ctônico e terrestre, fazia pacto com o anjo decaído e promovia berzabuns"’[pág. 90].

Deve ser assinalado o equívoco semântico de equiparar os vocábulos demônio e diabo: Aurélio Buarque de Holanda instrui que "demônio" deriva do grego daímon, "deus, deusa", "divindade", sendo sua acepção, nas crenças da Antiguidade e no politeísmo, a de "gênio inspirador, bom ou mau, que presidia o caráter e o destino de cada indivíduo; alma, espírito". Apenas pela força da doutrina monoteísta judaico-cristã pode adquirir o significado de "diabo", gênio do mal, anjo dissidente e decaído, Lúcifer. Aliás, a etimologia de "epilepsia", fornecida pelo próprio Palomba, já alerta sobre a imperfeição do ajuste efetuado: na epilepsia, o indivíduo era abatido por um demônio que estava acima dele, 
não havendo relação direta possível (embora não se descarte a possibilidade de outro gênero de relação) com o indivíduo que transitava livremente pelos mundos ctônico e terrestre, e isto sem sequer considerar que, para o grego antigo, o mundo ctônico nada ou muito pouco tinha em comum com o reino do anjo decaído.

Esta interpretação da epilepsia como possessão demoníaca atravessou milênios, e o autor comenta que, ainda no final do século passado, era conceituada pelos tratadistas como "afecção sine matéria do sistema neuromuscular". A passos largos, Palomba percorre o desenvolvimento da caracterização moderna da epilepsia, libertada, enfim, "das densas nuvens do escuro pensamento nada científico para ser iluminada pela luzes da ciência”, atribuindo notável importância a alguns estudos, todos realizados no Laboratório de Estudo do Cérebro do Hospital de Juqueri, em Franco da Rocha.

Primeiramente, destaca as pesquisas realizadas por Otávio Perez Velasco, sobre a anatomia dos cérebros de pacientes com diagnóstico de epilepsia genuína, ou seja, nas quais estão presentes os paroxismos convulsivos, que teria estabelecido o substrato anatomopatológico da epilepsia, com base no qual propôs o conceito do Cérebro Epiléptico [referido a: Perez Velasco, O: Clinicoanatomical Contribution to Present Day Concepts on Epilepsy. Boletim do Centro de Estudos Franco da Rocha, Vol. V: XII, n ${ }^{\circ}$ 1. 1950], e as pesquisas de Walter Edgard Maffei, que estendeu as conclusões e conceitos de Velasco sobre a epilepsia genuína a outras formas do mal, sustentando que "a epilepsia é uma só, baseado no conceito de o substrato anatomopatológico ser um só"'[referido a: Maffei, W. E.: As Bases Anatomopatológicas da Neuriatria e Psiquiatria. São Paulo, Imprensa Metodista, 1951], portanto, "síndromes sensoriais, 
viscerais ou psíquicas [sem o quadro convulsivo], passaram a ser consideradas como de natureza epiléptica” [pág. 90-91].

Em seguida, Palomba destaca os estudos de Átila Ferreira Vaz, de quem foi colaborador na década de 70 , sobre "cérebros de pacientes que, em vida, receberam o diagnóstico de personalidade psicopática”, cujos resultados levaram-no à conclusão de que "o cérebro de psicopatas explosivos ou epileptóides apresenta as mesmas malformações descritas por Velasco ao estudar a dita epilepsia genuina" [referido a: Vaz, A F: Tratado de Psiquiatria (São Paulo, Edigraf, 1971), Aproximação de Conceitos Neuropsiquiátricos (Ver. Arquivos, Vol. 23, 1957), e Conheça Psiquiatria (São Paulo, Edigraf, s/d)].

Desta caracterização moderna, Palomba deduz a "imposição categórica de dividir o velho mal sagrado em formas clínicas "[pág. 92], o que passa a fazer, afirmando a existência de três formas principais de epilepsia, conforme segue: "As três formas são: neurológica, relacionada à velha possessão demoníaca completa; psicótica, relacionada à velha possessão demoníaca incompleta e condutopática ou comportamental, relacionada ao homem ruim que fazia pactos com o diabo, às vezes bruxo, feiticeiro."[pág. 92].

A epilepsia neurológica "diz respeito às manifestações epilépticas cujos sintomas e sinais predominantes são os de ordem orgânica, ainda que possa haver perda ou comprometimento da consciência"'[pág. 92], incluindo-se nesta forma as crises parciais simples, caracterizadas por sintomas motores; as crises parciais com sintomatologia neuro-vegetativa, tais como piloereções, taquicardia, incontinência urinária, alguns distúrbios das funções nervosas superiores sem comprometimento da consciência, como dismnésias e lapsos, e crises epilépticas simples com sintomas sômato-sensoriais, como escotomas cintilantes, fosfenos e outros; 
e as crises epilépticas generalizadas, convulsivas e não-convulsivas. Sobre as relações desta forma epiléptica e criminalidade, Palomba afirma que "o epiléptico neurológico não delinqüe mais do que o homem dito normal, porque, nessa forma, o mal é neurológico, não psíquico” [pág. 99]. A epilepsia psicótica apresenta diferentes quadros mórbidos: a psicose epiléptica; o estado crepuscular não lúcido ou status epilepticus de ausência; o furor epiléptico; e os distúrbios do humor. A psicose epiléptica "é um distúrbio engendrado pelo cérebro epiléptico que consiste em alterações graves do psiquismo, semelhantes às que se verificam na esquizofrenia paranóide" [pág. 93], embora existam diferenças entre ambas. O diagnóstico diferencial entre as duas psicoses é facilitado pela presença, na epilepsia psicótica, de sinais e sintomas da epilepsia forma neurológica. Afirma Palomba que “quando não há história pregressa de crises convulsivas generalizadas, encontram-se outras de manifestações orgânicas do círculo comicial: mioclonias, cefalalgias hemicrânia, enurese noturna, fosfenos, escotomas cintilantes, poriomania etc." [pág. 94]. Quanto aos distúrbios de humor, o autor deixa indicada a sugestão de que a psicose maníaco-depressiva estaria relacionada, também, ao cérebro epiléptico [referido a: Coura, S. H.: Psicoses Maníaco-Depressivas, Etiologia e Patogenia. Boletim do Centro de Estudos Franco da Rocha, vol. 14, 1981].

Interessam mais de perto o estado crepuscular e o furor epiléptico, posto que ao longo do livro Palomba ressalta a importância destas condições na conduta homicida. Segundo o autor, a ingestão de álcool pelo indivíduo portador de cérebro epiléptico, mesmo em doses moderadas, pode desencadear o furor epiléptico, caracterizado por estreitamento de consciência, automatismos motores e verbais e irritabilidade. São freqüentes as explosões hetero e auto-agressivas, resultando muitas vezes em homicídios, suicídios ou automutilações. Este 
quadro costuma durar algumas horas, e ao seu término o indivíduo queda exausto, prostrado em sono profundo; em regra, uma amnésia lacunar cobre todo o episódio psicótico.

Quanto aos estados crepusculares, sempre segundo o autor, podem durar desde alguns minutos, até semanas. Caracterizam-se por turvação da consciência, desde sua obnubilação até confusão extrema. Dependendo do grau de estreitamento e desagregação da consciência, os atos do indivíduo podem apresentar-se ordenados ou desordenados, mas sempre denotando anormalidade. Também a estes estados sucede-se o sono profundo e amnésia completa sobre o período do surto. Podem ocorrer desordenadas crises de pânico e acessos de agressividade, com liberação de automatismos motores e verbais, geralmente em episódios curtos. Mas "às vezes a consciência fica orientada em um determinado sentido ou segundo uma forte tendência afetiva, e o indivíduo passa a praticar atos complexos" [pág.94].

A explanação teórica da epilepsia condutopática inicia-se no capítulo II, na classificação dos criminosos fronteiriços, e prossegue ainda no capítulo IX, os condutopatas. No capítulo VI, que ora é apresentado, Palomba define-a no seguinte parágrafo: "Epilepsia condutopática, em suma, pode ser assim enunciada: certos cérebros epilépticos engendram hipersincronias neuronais (disritmias cerebrais), que afetam a capacidade de auto-crítica e de julgamento dos valores éticos e morais, e a afetividade, $o$ entendimento e a conação, resultando em atos complexos condutopáticos, comportamentais, (atos em curto-circuito, atos psicopáticos, reações primitivas) que tendem a repetir-se e cronificar-se (personalidade psicopática), estando sujeitos a fatores desencadeantes externos, às vezes banais. Esses indivíduos não sofreram crises convulsivas ou, quando muito, algumas poucas vezes na infância. Entretanto, sempre 
apresentam vários equivalentes comiciais, como, por exemplo, enurese noturna tardia, escurecimento de vista, escotomas cintilantes, crises de pavor noturno, sensação de rotação do corpo, cefalalgia hemicrânia, sonambulismo, vigilambulismo etc." [pág. 98].

Contudo, as consequiências deste enunciado apenas podem ser extraídas das afirmações feitas em pontos distintos do livro. Assim é que, no capítulo II, o autor estabelece com toda clareza que os criminosos fronteiriços são precisamente epilépticos condutopatas que delinqüiram: "loucos morais, loucos lúcidos, idiotas morais, psicopatas, condutopatas, são alguns [dos nomes] mais usados. Dedicaremos um capítulo especial a esse interessante tipo de criminoso (capítulo IX).” [pág. 24]; portanto, é de epilépticos condutopatas que fala quando afirma, na mesma página, que "os grandes delinqüentes desse tipo [fronteiriço] delinqüem especificamente. Por exemplo, há aqueles que só matam homossexuais, outros só prostitutas etc., mas todos seguem um determinado ritual. Uns matam depois de embebedar a vítima; outros, depois de amarrá-las. Uns põem fogo no cadáver; outros, cortam etc. Os exemplos não minguam”.

Esta imagem do epiléptico condutopata torna-se mais contundentemente nítida no final do capítulo IX, quando Palomba afirma a existência de "um tipo especial de epiléptico condutopata de extrema periculosidade e incorrigivel. É o assassino serial (serial killer), ao qual dedicaremos um capítulo específico (capítulo $n^{\circ}$ XVI)” [pág. 142]. No capítulo anunciado, diz sucintamente: "psiquiatricamente [os serial killers] quase sempre são tipos que podem ser fundidos com os condutopatas, o que permite dizer que são condutopatas assassinos seriais. A deformidade está na falta de senso moral, na afetividade subdesenvolvida, na vontade fraca, no entendimento limitado, sem comprometimento da inteligência, da memória, da senso-percepção, da vigilância. Íntegras estas últimas 
faculdades, os assassinos seriais fronteiriços agem como se fossem normais, planejando, dissimulando, ocultando-se para evitar que sejam descobertos. Mas a ação é fria, cruel, insensível, egoísta, perversa. Sentem prazer na maldade em si, na vingança, na morbidez” [pág. 223]. E há bem pouco mais que isto, durante todo o livro: apenas a indicação do cérebro epiléptico como causa suficiente para tanto mal.

Palomba assevera que a epilepsia condutopática designa com melhor propriedade situações de perturbação da saúde mental, antes designadas por diferentes nomes: "personalidade psicopática explosiva" (Schneider), "personalidade psicopática excitável” (Kraepelin), "personalidade psicopática icto-afim" (Mauz), "psicopata brutal impulsivo" (Baer), "psicopata epileptóide” (Kretschmer). Argumenta que "personalidade psicopática é uma ficção, pois o indivíduo com tais e tais distúrbios de conduta ou é um neurótico ou um esquizofrênico simples ou um débil mental ou um epiléptico condutopata” [pág. 141] ${ }^{68}$. Sustenta o autor: "uma vez diante de uma então dita 'personalidade psicopática', correto é identificar perfeitamente a patologia básica que está causando o distúrbio de conduta" [pág. 141]. Esta identificação, afirma, é sempre possível, atentando-se para os "inconfundíveis sinais e sintomas clínicos da epilepsia" (os equivalentes comiciais citados acima, no final da página 208) e para os "característicos do crime” [pág. 142]. Distrai-se Palomba de que estes característicos constituem precisamente a conduta cuja causa sua análise pretende estabelecer.

\footnotetext{
${ }^{68}$ Sobre a crítica de Palomba ao conceito de "psicopatia" pode-se consultar também: Palomba, G. A , Delenda Psicopatia. "Psiquiatria Biológica": Associação Brasileira de Psiquiatria Biológica 7(2): 77-79, 1999.
} 
Sustenta o autor que "todo o delito violento praticado por epiléptico obrigatoriamente tem que ter quatro dentre os sete característicos enumerados a seguir: 1) ausência de motivos plausíveis; 2) falta de premeditação; 3) ferocidade na execução; 4) instantaneidade na ação; 5) multiplicidade de golpes; 6) ausência de remorso; 7) amnésia ou reminiscências mnêmicas confusas sobre o ato praticado” [pág. 101].

Não é o caso de deter-se na consideração do conteúdo destes característicos ou da regra de sua aplicação; interessa apenas perceber que, quando os sistematiza, aplica e apregoa, o autor faz mais que catalogar os elementos típicos do delito violento praticado por epiléptico: esta sistematização professa uma subversão do procedimento pericial, na medida em que vincula o diagnóstico psiquiátrico às características do crime, conforme foram interpretadas e registradas pelos orgãos policiais e judiciários. A lembrança das discussões introdutórias ao tema do homicídio violento, especialmente quanto à qualidade do registro policial do crime e quanto à instauração do Incidente de Insanidade Mental que determina a perícia (vide tópico As confabulações sociais sobre os homicídios violentos), podem iluminar este entendimento.

Recuperando a seqüência de eventos que vai culminar no diagnóstico psiquiátrico torna-se visível que o registro policial do crime condiciona todas as interpretações subseqüentes, inclusive a ordem judicial para a perícia, comumente formulada com base nas informações constantes do Inquérito Policial. Deste modo, antes de proceder ao exame do criminoso o perito é informado sobre os característicos de seu delito, aqueles mesmos que, por contrariarem as pré-concepções dos manipuladores técnicos que se ocuparam do caso sobre normalidade e loucura, humanidade e ferocidade, levaram o juiz a duvidar da integridade mental do réu - que é o que a perícia trata de verificar. No caso específico 
de Roberto, Palomba deixa claro em seus depoimentos que havia presenciado seu interrogatório inicial, pelo juiz de instrução da causa, bem como a tentativa de reconstituição do crime, antes mesmo de iniciar seu exame de sanidade mental, bem como que havia conversado com alguns delegados de polícia e investigadores que trabalhavam no caso.

Pretende o Direito que o laudo psiquiátrico forense constitua prova verdadeira da responsabilidade ou irresponsabilidade subjetiva do réu, condição de sua culpabilidade, pelo ato contrário aos seus ditames; e pretende ainda que esta prova, como qualquer outra, produza-se absolutamente isenta da participação dos encarregados do julgamento sobre a culpa ou inocência do réu, condição da Justiça. No Direito, o conhecimento especializado da psiquiatria sobre a verdade da alma do réu confere ao laudo psiquiátrico seu valor de verdade, enquanto a isenção do sistema judicial em relação à produção das provas que serão julgadas confere às sentenças seu valor de justiça. Na psiquiatria, a verdade do conhecimento sobre a alma deriva da cientificidade do procedimento adotado em sua procura.

Para a psiquiatria forense, submetida simultaneamente às exigências do direito e da psiquiatria, o ideal seria mensurar objetivamente o conteúdo da alma do réu, estabelecendo com total imparcialidade e autonomia o verdadeiro montante de razão e livre-arbítrio disponível para ele no momento de seu crime. Mas a psiquiatria não possui instrumentos totalmente objetivos para esta mensuração e, embora possa encontrar algum apoio nos exames neurológicos, seu principal recurso, já não para mensurar mas apenas para estimar o conteúdo da alma, ainda provém da nosologia; evidentemente, a precisão desta estimativa depende da perfeição do diagnóstico, o que, no sistema de verdade da psiquiatria, faz recair sobre este processo a importância da objetividade e imparcialidade. 
Mas é também evidente que tendem a escapar ao controle do psiquiatra forense a influência exercida pelas informações prévias que recebe a respeito do periciando e de seu crime sobre suas hipóteses diagnósticas, logo sobre todo o processo diagnóstico até sua conclusão; assim como escapam ao seu controle as condições de registro, interpretação e transmissão destas informações. Estas circunstâncias são potencialmente lesivas à imparcialidade e à objetividade do procedimento diagnóstico e, portanto, bastam para desvirtuar o laudo pericial sobre a sanidade mental do réu pois solapam seus critérios de isenção e verdade, exatamente as virtudes que dele exige o direito penal.

Contudo, enquanto decorrem da organização estipulada pelo direito para o sistema judicial, estas circunstâncias não impedem à psiquiatria forense uma autonomia de princípios em face das préconcepções leigas quanto aos critérios de razão, normalidade e loucura, mesmo quando um perito se deixe influenciar, inadvertidamente, por estas pré-concepções transmitidas no bojo da ordem de perícia. É diferente, porém, quando um psiquiatra forense professa tomar-se como recurso diagnóstico os caracteres do crime segundo foram observados e registrados por manipuladores técnicos leigos em psiquiatria, especialistas em outras áreas de saber, participantes de outros sistemas de verdade.

As premissas da psiquiatria operam quando o perito procura enxergar a alma do criminoso através da lente de sua hipótese diagnóstica, mesmo quando esta lente esteja inadvertidamente contaminada por préconcepções alheias, pois o próprio enquadre científico da psiquiatria postula a possibilidade, logo a exigência, de perceber e criticar esta contaminação. Mas a profissão de Palomba sustenta a possibilidade de que uma lente alheia à psiquiatria e à ciência sirva para o perito enxergar a 
hipótese diagnóstica através da qual deve orientar o exame da alma do criminoso; aquelas pré-concepções contaminantes subvertem-se em premissas aceitas e professadas; a psiquiatria forense já não as pode criticar. Isto não se pode confundir com humildade científica, nem com uma atitude inter ou transdisciplinar. Esta profissão, exercida e apregoada pelo perito, destitui a psiquiatria forense de sua especialidade, antepondo às suas premissas outras que lhe são estranhas, abdicando assim de sua posição.

No limite, sistematizadas as equivalências entre os quadros característicos dos crimes e os quadros nosográficos da psiquiatria, poderse-ia prescindir do psiquiatra forense: o enquadramento de um crime, resultante da observação, interpretação e registro efetuados pelos policiais e serventuários da justiça, automaticamente inscreveria seu autor sob a correspondente rubrica psiquiátrica, cuja nosografia estabeleceria já uma estimativa da razão e livre-arbítrio do criminoso, bem como de sua periculosidade e emendabilidade, segundo reiteradas afirmações de Palomba ${ }^{69}$.

Antes deste limite, mas já deslocada de sua especial posição a psiquiatria forense (posição na qual o perito poderia criticar as préconcepções leigas sobre a normalidade e a loucura), o laudo pericial sobre a sanidade ou insanidade mental do réu reduz-se ao endosso aparentemente científico aos pressupostos que orientaram a ordem judicial para a perícia. Compreendida em suas conseqüências, a sistematização dos característicos obrigatórios a todo delito violento perpetrado por epilépticos pode ser

\footnotetext{
${ }^{69}$ Em diversos trechos do livro, como alhures, Palomba reitera o prognóstico para o criminoso portador de epilepsia condutopática: "a reincidência é certa", a justiça deveria "mantê-los longe da sociedade, muitas vezes necessário seja por quanto tempo viverem, para a salvaguarda social", em "segregação perpétua".
} 
inserida entre as ações que solidariamente constróem a resposta social ao crime e ao criminoso, em cujo enunciado o conceito de loucura denota desumanidade. Ficam como questão os motivos suficientes para engendrar em Palomba esta profissão de renúncia à sua especialidade.

Em compensação, Palomba é bastante zeloso da conceituação da condutopatia, o que se evidencia em seu empenho em apagar, riscar, destruir $^{70}$ o conceito de personalidade psicopática proposto por Kurt Schneider. Revendo a formulação deste conceito, conforme foi apresentada em 1923, verifica-se que Schneider consigna os "crimes brutais" aos psicopatas dos tipos explosivo e desalmado. Suas hipóteses explicativas são, essencialmente, idênticas às de Palomba: os psicopatas explosivos (também chamados "epileptóides") matariam mediante um "ato em curtocircuito", durante uma "absense" - é basicamente o mesmo que o ato em curto-circuito do epiléptico psicótico, durante o estado crepuscular não lúcido ou durante um episódio de furor epiléptico. Os psicopatas desalmados chegariam ao homicídio pelo embotamento afetivo frente aos homens e pela amoralidade, resultantes de uma apreensão intelectual ou afetiva deficiente dos conceitos morais - é basicamente o mesmo que se pode ler sobre os atos condutopáticos do epiléptico condutopata em Loucura e Crime, à página 98 (vide citação acima).

Porque, então, Palomba convida-nos a gritar pela destruição do conceito de psicopatia? Qual a gritante diferença entre seu modelo explicativo e o de Schneider, capaz de justificar convite tão dramático? Pareceu-me que a principal diferença refere-se ao enquadramento nosológico da psicopatia/condutopatia. Para Schneider, o conceito de

\footnotetext{
${ }^{70}$ Na edição citada do artigo "Delenda Psicopatia", o significado do vocábulo delenda é cuidadosamente expresso sob o título: “*Deleo, es, ere, evi, etum: apagar, riscar, destruir. Delenda Cartago: destrua-se Cartago (Cícero)". Palomba encerra sua argumentação com o parágrafo: "Portanto, a bom direito, gritemos: delenda psicopatia."
} 
personalidade psicopática não se articula com os conceitos de enfermidade, patologia ou doença nervosa, pois não haveria qualquer componente corporal associado à sua origem e desenvolvimento; sua origem seria essencialmente disposicional. Palomba, diferentemente, afirma que a causa da condutopatia é o cérebro epiléptico [pág. 95], cujo funcionamento patológico engendraria variados tipos de distúrbios de conduta [pág. 97], podendo resultar na prática dos mais cruéis delitos [pág. 141].

Retomemos agora a explanação sobre a epilepsia condutopática, e vejamos como o autor vincula o foco epiléptico detectável pelos sintomas clínicos (já está claro que, para Palomba, a morfologia do crime é um deles) e a conduta homicida característica, ritualizada e repetitiva: "indivíduos que dessa forma de epilepsia padecem possuem limiar de excitação cerebral baixo, porque portam cérebro epiléptico. Recebem os fatos do mundo pelos sentidos, nas vias nervosas periféricas, que se enlaçam aos centros protopáticos e epicríticos sensitivos, motores e mnêmo-associativos cerebrais, que, dependendo do estímulo, duração e intensidade, engendram hipersincronias neuronais, emitindo estímulos que chegam aos nervos que se ligam à musculatura, assegurando a continuidade funcional altamente complexa ou bem simples, entre a impressão, a elaboração e a expressão, com sintomatologia biopsicossocial inerente à alteração cerebral.” [pág. 96/97].

Em termos neurológicos, a crise condutopática seria então resultante de uma crise [epiléptica] parcial complexa; no nível da consciência, esta crise determinaria um estado crepuscular lúcido ou orientado [pág. 95]. Neste estado de consciência, o indivíduo praticaria "atos complexos, ordenados, que podem durar minutos, horas ou dias, sem perder a consciência, com a memória geralmente conservada. Há 
diminuição da capacidade de entendimento, com comprometimento da esfera conativa e do mecanismo de controle emocional, afetivosentimental" [pág. 96]. Em outras palavras, a ordenação, que confere forma ao ato, derivaria da particular configuração cerebral do indivíduo: uma vez ativados os centros cerebrais "doentes" com energia suficiente para engendrar uma hipersincronia neuronal, o indivíduo quedaria "paciente" de seu cérebro, ou seja, de sua doença.

Palomba acata sem reserva a explicação da epilepsia proposta por Velasco, sumariada no trecho onde lê-se: "o desencadear da crise epiléptica seria explicado [por Velasco] por uma descarga do paleocortex ou dos núcleos arquiencefálicos dele dependentes, produzindo em conseqüência a inibição do neocortex e a liberação dos centros inferiores"; este funcionamento anormal seria resultante de uma alteração no desenvolvimento cerebral, determinante de um desequilíbrio anatômico entre os dois hemisférios cerebrais ou de parte deles [nota 39, página 91].

Isto ajuda esclarecer a natureza da analogia sugerida pela descrição do ato condutopático como "ato em curto-circuito": a imagem transmitida pelo autor é a de um traçado fixo, que enlaçaria feixes neuronais aferentes, centros mnemo-associativos e feixes neuronais eferentes, destacado e inteiramente isolado do restante da rede neuronal precisamente pela fixidez de suas conexões. Apresentando-se um estímulo adequado, a seqüência da estimulação seguiria um curso invariável, sendo inexorável a execução dos atos condutopáticos correspondentes ao ramo eferente daquele "laço" doentio, da mesma maneira como seria inexorável a emergência para a consciência de determinadas imagens mnêmicas e o estabelecimento de determinadas associações. Isto explicaria a especificidade do delito, e também a incorrigível periculosidade do criminoso. Todo este processo ocorreria em automática consonância com o 
conteúdo das porções neuronais ativadas em conseqüência da hipersincronia, e sem qualquer modulação por parte do entendimento, função nobre do neocortex, posto que a reação primitiva desenrolar-se-ia inteiramente à margem da atividade cortical. Durante a crise condutopática, ficariam sustadas as capacidades de auto-crítica e de julgamento dos valores ético-morais, restando assim esfacelada a conatividade. Também estariam inoperantes os controles racionais e afetivo-emocionais da conduta.

Esta imagem transmitida pelo texto revela, subjacente, a estreita analogia operada com a situação de curto-circuito num sistema elétrico, quando uma conexão acidental oferece um circuito de mínima resistência ao fluxo elétrico, desviando-o do curso resistente que o tornaria utilitário. $\mathrm{O}$ modelo explicativo sugerido é essencialmente similar ao do "arco reflexo" e, de fato, o linguajar de Palomba corrobora esta compreensão. Assim é que afirma, no capítulo IX, quando discorre sobre as peculiaridades dos crimes violentos praticados por epilépticos condutopatas, que “...via de regra, a memória [sobre o crime] quase sempre está conservada, nunca há remorso e o delito pode dar uma falsa idéia de premeditação. Em verdade, são apenas atos ordenados, complexos, mas desprovidos de crítica, de emoção, de sentimento superior, que os franceses chamam de "automatismos mentais de longa duração”. Esses estados estão associados à anormalidade cerebral ligada ao lobo temporal, e é como se o paciente estivesse assistindo a um filme, a cujas cenas projetadas está alheio, sem sentimento e sem crítica. Terminado o "espetáculo", acabada a sessão, o paciente pode lembrar-se do que viu, mas como "assistiu ao filme" sem sentimento, obviamente não tem remorso (...) Não há emoção, nem durante, nem depois" [pág. 142]. 
Compete aos psiquiatras e neurologistas julgar a validade específica deste modelo explicativo para a conduta criminosa, confrontando-o com os conhecimentos acumulados nestes campos, relativos ao funcionamento cerebral e aos meios disponíveis para o diagnóstico da epilepsia; mas certamente cabem-lhe reparos importantes do ponto de vista da psicologia.

É preciso notar, primeiro, a fragilidade da explicação causal proposta: não é evidente, por si, que um ato em curto-circuito, uma reação primitiva, deva ser obrigatoriamente "psicopático", no sentido de antisocial e cruel. Mesmo admitindo-se que um distúrbio cerebral possa resultar em atos pouco ou nada voluntários e/ou conscientes, ainda ter-se-ia que explicar porque estes atos dirigem-se contra os preceitos da vida em sociedade e porque assumem determinada forma. Especialmente quando sustenta-se, como Palomba, que assumam formas bastante específicas ${ }^{71}$. Acatar sua explicação implicaria em afirmar que a porção primitiva do cérebro humano abriga cadeias neuronais aferentes, mnemo-associativas e eferentes, pré-ordenadas para desencadear respostas anti-sociais e cruéis bastante específicas (esfaquear, envenenar, atear fogo, etc), diante de determinados estímulos (a repreensão de um familiar, a atitude sedutora de uma prostituta, um homossexual, etc). Evidentemente, a interpretação do crime como "reação primitiva", como sustenta Palomba, é inadmissível.

No máximo, pode-se admitir que um ato em curto-circuito incline-se a atualizar conexões prévias, estabelecidas por um processo

\footnotetext{
${ }^{71}$ Devem ser lembradas as afirmações de Palomba, citadas à página 210 , falando dos epilépticos condutopatas: "os grandes delinqüentes desse tipo delinqüem especificamente. Por exemplo, há aqueles que só matam homossexuais, outros só prostitutas etc., mas todos seguem um determinado ritual. Uns matam depois de embebedar a vítima; outros, depois de amarrá-las. Uns põem fogo no cadáver; outros, cortam etc. Os exemplos não minguam".
} 
social de condicionamento quanto aos modos de expressão da agressividade e os objetos preferenciais para a agressão. Mas apenas isto já colocaria de volta a necessidade de estudar os conteúdos destes condicionamentos que conferiram a forma precisa de cada homicídio.

Finalmente, deve-se atentar para o modo como Palomba sustenta a incorrigível periculosidade do indivíduo, advertindo que "normalmente, $o$ delito violento praticado por epiléptico, seja de que forma for, mostra, por si, que o doente é portador de alta periculosidade, e portanto capaz de reincidir. Às vezes os sinais de conduta agressiva podem começar em tenra idade, outras vezes, pouco mais, pouco menos, no final da adolescência: é o crime como que primeiro ato de uma série de muitos. Quando começa cedo, via de regra, não amaina nunca; quando na adolescência, início da juventude, com a idade a conduta agressiva passa para o comportamento marginal: os crimes são menos impulsivos e mais pensados "[pág. 100. Grifo meu].

Note-se que esta constatação (que grifei) não se coaduna com as afirmações de Palomba sobre o caráter involuntário, puramente reflexo, do ato criminoso dos epilépticos: sob a forma psicótica, o autor os descreve como sendo "uma verdadeira convulsão, que não difere da convulsão comum, senão pelos movimentos combinados em relação a um fim determinado" [pág.25], ou, no caso da forma condutopática, como "apenas atos ordenados, complexos, mas desprovidos de crítica, de emoção, de sentimento superior [podendo ser chamados de] 'automatismos mentais de longa duração', resultantes de um impulso mórbido associado a um estado de estreitamento da consciência (estado crepuscular) - nada mais que sintomas da doença [pág. 142]. Se as ações criminosas dos epilépticos transformam-se com a idade do indivíduo no sentido de menor impulsividade e maior reflexão - e a larga experiência de Palomba neste 
campo deve bastar para angariar nossa confiança em sua constatação deve-se ao menos suspeitar que sejam algo distinto de uma convulsão ou de um automatismo.

Então, torna-se imperioso perguntar porque Palomba afirma reiteradamente, sempre com terminante convicção, que no caso do indivíduo epiléptico, seja na forma psicótica, seja na forma condutopática, os delitos, "ao cabo são expressões sintomáticas do mal” [pág. 101]. Aqui não se trata, está claro, de questionar a doença epilepsia, nem sua descrição ou os recursos que permitem seu diagnóstico; deve, sim, ficar sob suspeita que determinados crimes sejam tão somente sintomas desta doença. Há uma inevitável indelicadeza nisto: equivale a colocar sob suspeita, além do diagnóstico de Roberto, todo o modelo explicativo oferecido por Palomba para 14 casos de homicídio violento (tentados ou consumados), dentre os vinte apresentados em Loucura e Crime.

\section{Notas para um novo modo de confabular}

\section{dentro do campo psi.}

Em minha leitura dos textos de Feldman e Paiva, apontei insistentemente as passagens onde cada um destes autores resvala para uma explicação biológica da conduta homicida violenta. Pretendia com isto assinalar que ambos, em essência, sugerem que o homicida seria portador de uma predisposição biológica perversa e pouco propícia ao estabelecimento de vínculos amorosos; depois, que esta disposição biológica seria acirrada pelo infortúnio de um ambiente familiar desfavorável até que, finalmente, estivesse estabelecida uma personalidade 
insensível, incapaz de amor e de empatia, e dotada de impulsos particularmente cruéis. Em acréscimo, a perversidade do indivíduo ainda poderia ser estimulada pela exposição a modelos agressivos ou pelo contato com um meio social inadequado.

O esquema apresentado por Palomba apenas desprezaria as contribuições respectivas dos meios familiar e social na formação da personalidade perversa e na estimulação do comportamento criminoso; de resto, seria semelhante aos demais.

Todos estes autores consideraram relativos ao plano individual os aspectos biológicos, psíquicos e familiares, e relativos ao plano coletivo os aspectos sociais mais amplos, como a escola, a mídia, os aparatos legal, judiciário e penal, etc. É notável a contaminação recíproca nas conotações de termos como, de um lado: "indivíduo", "interno", "psíquico", "particular", "privado", "familiar", e de outro: "grupo", "externo", “conduta”, "comum”, "público”, "social”.

Evidentemente esta seriação não é casual, mas resultante do desenvolvimento histórico destes conceitos. Faz-se necessário resgatar a complexidade, ao mesmo tempo que o sentido "empírico" de cada um destes termos: o mundo "interno" de um indivíduo está repleto de imagens "comuns" a muitos outros indivíduos da mesma cultura; a "conduta" humana implica sempre na articulação de elementos de ambas as séries; "indivíduos" desempenham papéis "sociais"; as "famílias" ocupam posições definidas no contexto "social" e estas posições resultam em acesso diferencial aos recursos econômico-culturais, com repercussão sobre as experiências "privadas" de seus membros e sobre suas atuações "sociais"...

É claro que o modo dicotômico como especialmente Feldman e Paiva organizaram as coisas tem ressonâncias com as explicações usuais 
das interações entre indivíduo e coletivo e padece, como sói acontecer com as teorias em psicologia social, dos desvios psicologizantes e socializantes. Seria necessário, para superar estes desvios, compreender o que torna tão difícil olhar a interação indivíduo-coletivo de modo concreto e explicitar os processos implicados em sua realização.

Parte destas dificuldades surgiram ao longo do desenvolvimento histórico das ciências humanas, pelo engendramento e cronificação de antinomias que constituem a maneira de pensar do homem atual ${ }^{72}$. É importante notar que estas antinomias não "impregnam", não "desviam" nosso pensamento, senão que são, já de longa data, parte constitutiva dele. Apenas a advertência sobre a complexidade da conduta humana, sobre a impossibilidade de compreender o homem pela consideração de aspectos isolados de sua natureza, etc., não basta para neutralizar a força coercitiva de antinomias como "inato x aprendido", "biológico x social", "corpo x mente" - força esta redobrada pelo fato de tratarem-se, em verdade, de antilogias; palavras que engendram sua própria realidade, porque dirigem a percepção e o raciocínio do sujeito, sem que disto ele possa tornar-se imediatamente consciente.

Acredito que Feldman, Paiva e Palomba, falharam em superar aquelas três aparentes antinomias, que não obstante criticaram explicitamente, os primeiros em razão da superficialidade e generalidade com que trataram as interações entre indivíduo e coletivo, desviando da consideração dos modos concretos desta interação, e o último, porque desconsiderou a dimensão simbólica do ser humano.

Mas, segundo a minha leitura, os modelos traçados pelos três autores estudados padecem, ainda mais, de um efeito biologizante, produto

\footnotetext{
72 José Bleger trata destas antinomias no primeiro capítulo do livro Psicologia da Conduta [Bleger, 1984].
} 
da incompreensão dos liames que, prendendo indivíduo e coletivo, prendem também o "psíquico" e o "social". Contra este efeito, será preciso enfatizar que não se pode encontrar explicação para qualquer conduta, boa ou má, de um indivíduo, sem compreender suas interações com o meio que o cerca; mas isto significa algo diferente do somatório de fatores proposto pelos autores estudados. Significa compreender o modo concreto como aqueles diversos fatores conjugam-se para condicionar, simultânea e congruentemente, o comportamento do indivíduo e da coletividade.

Por exemplo, não basta dizer que uma dotação biológica perversa, somada a um ambiente familiar pernicioso, resulta numa personalidade anti-social, propensa a cometer crueldades. Primeiro, será preciso entender o que significa, concretamente, nascer com dotação biológica particularmente insensível ao amor e aos outros (para usar o jargão de Feldman) ou particularmente tanática (para ficar com Paiva). Como deve comportar-se um bebê insensível? Ou um recém-nascido tanático?

Estes autores parecem usar o termo "biologia" ou "fatores biológicos" referindo-se essencialmente ao genótipo do indivíduo. Mas o genótipo não tem expressão na realidade cotidiana, logo não pode exercer qualquer efeito nas relações do indivíduo, senão pelo fenótipo que contribui para condicionar - e este já supõe o contato influente do meio. Nenhuma característica biológica manifesta-se inteiramente isenta da influência ambiental; naturalmente, no caso humano, o ambiente implica sempre numa ordem sócio-econômico-cultural. Dizer que a influência familiar opera sobre fatores biológicos, sem discriminar seus componentes genotípicos e fenotípicos, obnubila o alcance da influência social sobre a família e sobre a constituição biológica do indivíduo. 
Quando um ser humano chega a manifestar um instinto, um humor, uma compleição física, já o faz marcado pela particular situação de sua família numa ordem sócio-econômica-cultural, que influenciou as condições de seu desenvolvimento até o momento desta manifestação, mesmo a mais precoce. Ao nascer, o bebê humano já traz as marcas das condições nutricionais de sua gestação, os cuidados perinatais, os recursos materiais disponíveis para seu sustento, etc.

Além disso, a recepção de suas manifestações em seu ambiente familiar também estará previamente condicionada por influências desta mesma ordem. As demandas do bebê pelos cuidados típicos da maternagem envolvem necessidades materiais e de afeto; o modo como os adultos respondem sua demanda está condicionado pelos recursos econômicos e culturais que puderam auferir no contexto social em que estão situados.

Para buscar um exemplo extremo do que estou dizendo, pode-se recorrer à situação mais remota na qual um indivíduo demanda a satisfação de uma necessidade: ora, a resposta possível a um bebê faminto que chora depende das possibilidades materiais específicas da família em atendê-la. Mas, qualquer que seja a resposta material possível - dar-lhe ou não o alimento, qual seja, ou com que regularidade - estará implicado nela um colorido afetivo: o bebê só pode experimentar na relação com a família a gratificação ou a frustração envolvidas na situação de receber ou não o alimento e, por sua vez, a família experimenta na relação com o bebê os sentimentos resultantes da situação de dispor ou não dos recursos para atendê-lo.

Os adultos, porém, têm algumas palavras para nomear esta experiência; quando o fazem para si, transmitem-nas ao infante. $\mathrm{O}$ montante e a qualidade destas palavras é o que fica na dependência de 
quanto e como pôde a família dispor dos recursos culturais produzidos pela sociedade.

Parte essencial deste jogo refere-se às possibilidades que o adulto detém, ou não, de compreender e de expressar sua particular inserção social e sua particular inserção familiar. Seguindo o mesmo exemplo, quanto maior a consciência do adulto sobre a amplitude da situação na qual ele e o bebê se encontram, mais poderá nomear suas respectivas experiências de maneira abrangente, qualquer que seja a resposta material possível: no extremo da limitação da consciência adulta sobre a situação social e familiar de ambos, o adulto só pode nomear a experiência da demanda infantil e da sua própria possibilidade em atendê-la, referindo-a apenas à criança e à si mesmo; assim, quando a família ignora o contexto global determinante da sua experiência, a nomeação dela apenas pode distribuir ao adulto e à criança seus sinais positivos ou negativos ${ }^{73}$. Neste sentido, quando o adulto nomeia uma experiência, está ao mesmo tempo atribuindolhe um valor, e transmitindo-o ao infante. Este valor incorpora-se à criança, enquanto sua consciência possível a respeito de suas próprias potencialidades, condutas, necessidades, afetos e sentimentos e a respeito de sua posição relativa no mundo. A mensagem bruxa mencionada por Paiva adquire, dentro desta compreensão, outro aspecto; sua origem é encontrada no contexto social, não na biologia.

\footnotetext{
${ }^{73}$ Lembremos a situação de Dejanira e Quincas, relatada no preâmbulo deste estudo: incapaz de enunciar uma avaliação abrangente das condições sócio-econômicas que mantinham insuficientes os recursos para atender as necessidades de todos os membros de sua família, Dejanira atribuía à Quincas esta situação (ao seu comportamento delinqüente, ao fracasso escolar, ao desemprego, etc.), e simultaneamente atribuía-lhe certo valor pessoal: vagabundo, obtuso, preguiçoso, ruim, etc. Na impossibilidade, também condicionada por sua inserção social, de aprender a enunciar de outro modo sua própria situação, Quincas fatalmente reproduz o modo de Dejanira, acusando-a de licenciosidade, negligência, ruindade, egoísmo, etc.
} 
O esforço psíquico para estruturar a própria identidade e para satisfazer as próprias necessidades pressiona a criança a demandar novos nomes e valores; a discriminar as variações das expectativas do ambiente social; a captar modelos de condutas possíveis para si. À medida que ela cresce, sofistica-se a acuidade com que reconhece as oportunidades de obter respostas às suas necessidades e a eficácia de cada modelo de conduta possível em cada uma destas oportunidades, de acordo com suas próprias condições. Auxiliado pela exposição aos modelos sociais, o indivíduo integra estas representações de si mesmo e do mundo; passa a operar segundo os padrões de conduta construídos pelo jogo destas representações.

Nomeadas, as experiências da criança convertem-se paulatinamente em auto-imagem e em realidade. Objetivadas em suas condutas, estas representações estarão permanentemente expostas ao veredicto do meio familiar e social que, reagindo ao comportamento do indivíduo, cumula-as de novos nomes e valores. Neste sentido, a autoimagem opera como dispositivo integrador das características individuais e das características do ambiente social, condicionando a singular sensibilidade do indivíduo - ou seja: suas possibilidades de identificação aos modelos de conduta disponíveis no espaço social ${ }^{74}$.

A construção social de um modelo de conduta se faz por processos coletivos de simbolização, nomeação e valoração, similares aos

\footnotetext{
${ }^{74}$ Não acho oportuno nem útil precisar rigorosamente o conceito de auto-imagem. Com esta expressão, quero referir a percepção que o sujeito tem de suas próprias aspirações, qualidades e potencialidades, bem como de sua particular posição no contexto social enquanto fator condicionante das suas possibilidades de realizar seus desejos. Naturalmente, a tensão resultante do jogo simultâneo destas várias percepções sobre si mesmo - então, a própria autoimagem que estou referindo - deve orientar a escolha pelo indivíduo das condutas que lhe são mais adequadas para interagir com o ambiente em busca da satisfação de suas necessidades e desejos.
} 
que promovem a construção da auto-imagem individual. Feldman fala em modelos sociais reais e fictícios mas é necessário ponderar que o modelo é sempre depuração, recortes, montagens; o modelo social é sempre fábula, é o que pôde ser dito. Mesmo quando sustenta-se sobre a imagem de uma pessoa real, o modelo social não se constitui senão mediante extirpações e implantes: sobre o fluxo contínuo dos acontecimentos de sua existência, deve-se operar criteriosa interpretação e seleção - pode resultar mais verossímil, mas não é essencialmente diferente da ficção. No sentido em que o estou tomando, o modelo social é sempre personagem de fábula, é a personificação de um ideal de conduta referido a um contexto cuja descrição torna igualmente idealizado.

Talvez não seja indiferente o fato de ser uma pessoa real ou um personagem de cinema ou TV a servir de suporte para um dado modelo social de conduta. Mas é certo que a personificação tende a propiciar no observador uma reação global de aceitação (ou rejeição) do modelo apresentado, que prescinde da identificação com seu conteúdo total. Desde que o observador possa identificar-se com as características principais do personagem, estará inclinado a identificar-se também com as secundárias, digamos, com seu estilo; bem como a aceitar como válida as descrições do contexto de atuação do modelo e as justificativas para seu comportamento de tal forma que a assimilação de um modelo social de conduta pode determinar o reordenamento de largas porções das representações sobre si e sobre o mundo.

Os modelos sociais - assim como a auto-imagem - partilham com os mitos a possibilidade de misturar elementos logicamente imiscíveis; tratam-se todos de constructos igualmente simbólicos, fabulosos, mentirosos - esta qualidade isenta de crítica a exposição e a observação dos modelos sociais, como dos mitos. Assim como a transmissão da mensagem 
bruxa mencionada por Paiva, também a comunicação de um modelo social ocorre de forma predominantemente inconsciente, acrítica. Isto não significa que sejam aleatórios o conteúdo e a freqüência relativa dos diferentes modelos expostos no espaço social. Significa apenas que os sujeitos mais diretamente responsáveis por sua exposição e o sujeito que o observa e assimila estão todos parcialmente alienados dos fatores que condicionaram desde a construção até a comunicação de cada modelo específico.

Os modelos sociais, enquanto organizadores da auto-imagem e consequentemente da conduta do sujeito, podem, então, ser pensados como elos de articulação entre os planos individual e coletivo. Assim, quando crescido, já sujeito falante, o indivíduo porta a voz familiar e social. Suas condutas trazem embutidas esta voz, embora continuem a demandá-la - o sujeito age sempre esperando uma resposta do meio. Passa-se o mesmo com suas interpretações do ambiente social, que inclui a conduta alheia: o sujeito responde ao meio com a voz que lhe foi possível adquirir, neste mesmo meio. Palavras como indivíduo, coletividades, biológico, psicológico, familiar, social, passam a indicar momentos da análise da conduta humana, e não mais suas categorias possíveis.

Tudo quanto afirmei nos parágrafos precedentes, deve aplicar-se a qualquer objetivação da conduta humana, entre elas um homicídio violento, entre elas uma teoria científica que procure explicá-lo. Insistindo em apontar os desvios dos modelos oferecidos pelo campo psi para explicar a conduta dos homicidas violentos, fiquei obrigada a sugerir caminhos mais promissores.

Começarei dizendo, então, que a superação deste modelo pareceme exigir o abandono do projeto de encontrar, servindo-se apenas da 
"lógica", a verdade absoluta sobre os fenômenos humanos. A lógica esclarece relações entre conceitos, entre palavras. Mas o homem, que cria e usa as palavras, está presente ainda aquém e além delas. A experiência humana acontece antes do advento da palavra que a nomeia, e também porque foi nomeada; a experiência humana pode ser causa e conseqüência da palavra.

Quando a experiência humana é causada pela palavra não gera conhecimento, apenas repete, cristaliza, porque o sujeito desta experiência substitui o genuíno contato consigo e com o objeto pela representação lógica, verbal, deste contato: representação alheia, formulada pela história história familiar, história social, história da ciência - herdeira dos desvios resultantes das disputas de poder e dos compromissos do desejo.

Isto já é bastante sabido pelos psicólogos clínicos; na clínica, sabe-se que a transformação resulta de uma fala conseqüente da experiência, resulta da possibilidade de nomear a própria experiência, de reconhecer-se como sujeito de uma história que se atualiza, ainda que esta possibilidade construa-se a partir da oportunidade, oferecida pelo enquadre terapêutico, para falar, repetitivamente, sobre uma história na qual o sujeito aparece como objeto.

Falta ser aprendido pelos que trabalham na psicologia social; falta aprender que a nomeação prévia do mundo - o que é "indivíduo", "social", "biológico", etc. - por um lado, dirige nossa observação e nosso raciocínio, e por outro, não nos isenta de responsabilidade em sua atualização. Isto obriga-nos a criticar os conceitos construídos sobre o mundo, e a fazê-lo não a partir de outros conceitos, também históricos, alheios, mas a partir de uma experiência na qual assumimos nosso lugar de sujeito total, um sujeito humano, com tudo que isto implica. 
Trata-se, evidentemente, de criticar o discurso científico a partir da experiência subjetiva do mundo, do fenômeno que se quer conhecer; uma crítica que se constitui num novo discurso proferido para verbalizar aquela experiência. Também aqui, podemos aprender com os clínicos: eles trabalham manejando "instrumentos", como a contratransferência ou a empatia, que operam pela compreensão do contágio das experiências subjetivas, do cliente para o terapeuta; eles experimentam, no grau possível, a experiência do cliente, guardando porém a possibilidade de emergir desta experiência e de nomeá-la, compreendê-la; depois, utilizam esta compreensão para instruir suas intervenções facilitadoras da emergência, no paciente, desta fala genuína, subjetiva, desta pronunciação transformadora.

Estes mesmos "instrumentos" podem ser úteis ao psicólogo social para intentar a compreensão dos fenômenos que estuda com a diferença que, neste campo, ele mesmo deve pronunciar-se sobre aquilo que compreendeu. As teorias servem, em ambos os campos, como "âncoras" ou "bóias salva-vidas", que auxiliam a emersão, mas não o mergulho que possibilita a compreensão. Este mergulho não se faz sem angústia, e sem a possibilidade de sustentar esta angústia, pelo tempo e no grau possível.

A possibilidade de sustentar a angústia depende de muita coisa, algumas das quais talvez estejam além da nossa capacidade de apreensão e/ou de comunicação. Mas certamente não pode ser desenvolvida sem que o sujeito abandone a pretensão lógica, e o projeto de falar a verdade inteira e última sobre o fenômeno. É preciso que o sujeito admita que ainda não tem as palavras todas para verbalizar sua experiência, e mesmo se e quando as tiver, não serão as últimas. Servirão apenas como nomes, âncoras ou 
bóias de salvação para que ele próprio, ou outrem, possam re-experienciar e ressimbolizar o fenômeno.

Sumariando, parece-me necessário que o estudo das interações humanas, seja iluminado pela crítica das palavras e das categorias sobre as quais o conhecimento científico é usualmente construído, pela cautela com as armadilhas da língua dos homens - que obscurece aquilo mesmo que quer revelar - e pela lembrança de que as teorizações científicas são, também, falas humanas. Principalmente, parece-me necessário desenvolver um freio epistemológico e ético, para fazer protelar a satisfação do nosso humano pendor para reduzir o desconhecido ao que é sabido, o Outro ao Mesmo. Penso que devemos aprender a desprestigiar a coerência, as formas puras, as manifestações inequívocas, as identidades; devemos suspeitar sempre que tudo isto, em vez de verdade, sejam construções a serviço de sua dissimulação, sejam produtos da vontade de verdade.

A atitude, então, deve ser de abertura, mais que isto, de atenção para o acontecimento, para o inesperado, o cambiante, para aquilo que se apresenta como irrelevante ou contraditório, e que por esta abertura pode ser reconhecido como de surpreendente importância para a compreensão e para a transformação do discurso. Penso que esta atitude seja a mais adequada para permitir o conhecimento daquilo que é humano: um fenômeno social, um indivíduo, um grupo ou uma organização, um crime, uma teoria científica.

Enquanto não pudermos fazê-lo, é provável que não possamos enxergar em um homicida violento nada além de sua crueldade; e que os sinônimos científicos para a palavra monstro encerrem tanto ou mais dissimulação de nossa angústia diante do desconhecido, que conhecimento.

Resta-me provar um pouco do meu próprio remédio... 


\section{Capítulo 8:}

Um ensaio sobre homicidas e homens fabulosos 


\section{Um ensaio sobre homicidas}

\section{e homens fabulosos.}

Ao longo de todo o estudo do caso Roberto, procurei descobrir, entranhados em seus relatos, os vestígios das interações havidas entre as pessoas que se ocuparam daqueles homicídios. Desde o primeiro momento do crime, conforme foi relatado, até o seu julgamento pelo júri pareceu-me que todos estiveram, a maior parte do tempo, empenhados num confronto.

O objetivo manifesto das relações estabelecidas entre as pessoas delegados e testemunhas, juízes e delegados, peritos e Roberto, etc. - era saber a verdade sobre Roberto e os homicídios que havia praticado. Todavia, boa parte das falas registradas insinuam a intenção de um golpe, desferido com o objetivo de desacreditar a possibilidade de entender a verdade. Desacreditou-se, assim, a humanidade de Roberto...

Roberto, por sua vez, pouco falou no processo; aliás, mesmo antes do crime Roberto já falava pouco quando era descomposto: ele próprio, e as testemunhas de seu comportamento anterior - exceto seu tio Raul - disseram que Roberto nada retrucava ao pai quando este reclamava do volume do som, ou negava as chaves do carro; quando foi repreendido pela mãe, momentos antes do crime, também nada teria dito. Às acusações de Karin, de que ele era um vagabundo, que só incomodava, Roberto respondeu com um silêncio de morte: apanhou o revólver e tentou refletir...

Quando li pela primeira vez o relato que Roberto fez à polícia sobre este momento, senti um arrepio: eu já conhecia o desfecho da cena, mas ocorreu-me que, naquele instante, Roberto pensava em matar-se. 
Minha angústia aumentou um bocado quando li sua declaração sobre haver engatilhado a arma e, por manejá-la mal, haver detonado o tiro que atingiu a porta do quarto de seus pais. Num átimo, perguntei sobre como ele poderia justificar à mãe este disparo; também num átimo, Roberto respondeu minha pergunta, narrando as mortes de sua mãe, seu pai e sua irmã. Ainda restavam os dois irmãos que dormiam, e Roberto decidiu darlhes a mesma resposta muda, mortal. Naquela ocasião, Roberto não pôde lançar mão de outro recurso para responder à sua família.

Em pelo menos mais uma oportunidade Roberto precisou portar um revólver - provavelmente aquele mesmo; talvez também enquanto refletia sobre alguma coisa. Em 15JAN85, Adriano, namorado de Cristina, declarou à polícia haver visto Roberto com um revólver na mão, meses antes do crime. Nesta ocasião, Mário, Karin, Paulo e André estavam viajando; Cristina e Judite estavam no pavimento inferior, e Adriano subira para ir ao banheiro. Deparou então com Roberto no corredor do pavimento superior, segurando a arma. Roberto assustou-se; Adriano atentou para o coldre grande e vistoso; mas não trocaram qualquer palavra sobre o assunto. Não há registro de outras informações sobre o episódio. Certo é que o porte daquele revólver tinha para Roberto um sentido simbólico anterior/exterior aos homicídios que cometeu meses depois; aliás, esta arma devia parecer-lhe algo impertinente ao patri-matricídio que realizou, pois ele precisou esfaquear os corpos de seu pai e de sua mãe depois de os balear - a atitude de empunhar o revólver naquela noite trágica não estava inteiramente vinculada à decisão de matar sua família; ao menos em parte, vinculava-se a alguma outra coisa. Talvez, como me pareceu inicialmente, à idéia de suicídio; ou talvez o gesto de empunhar aquele revólver doméstico tivesse aos poucos adquirido para Roberto o valor simbólico de compensar suas fraquezas, de fazê-lo sentir-se poderoso, inatacável, invulnerável. Talvez tudo isto tenha começado de um modo pueril - do 
mesmo modo como as meninas não resistem a calçar às escondidas os sapatos de salto alto das mães. É perfeitamente razoável pensar que a desgraça daquela família principiou no fascínio que as armas, como outros símbolos da violência e da morte, exercem sobre boa parcela de nossos sócios culturais - Mário não deve ter encontrado qualquer dificuldade para adquirir aquele revólver; Paulo também tinha interesse pelo assunto: lia sobre guerras, sabia tudo de guerra.

Não pode haver dúvidas de que vivemos numa sociedade tanática e, instruídos por um século de psicanálise, não devemos estranhar isto: trata-se, é claro, da consequiência do zêlo com que procuramos remover de nosso cotidiano a inaceitável idéia da morte. Mas, aceita ou não, a morte se impõe ao homens. Na realidade, ela se apresenta como parte da nossa condição natural, ou como resultado da miséria e da truculência inerentes ao ordenamento perverso das relações sociais contemporâneas. Prodigalizam-se recursos humanos e materiais para eliminar as formas naturais da morte; velam-se suas formas sociais - não é coerente, não é racional, mas é lucrativo que assim seja: do ponto de vista empresarial, morte e violência são grandes negócios. Na imaginação humana, é inexorável a idéia da morte; resta à cultura oferecer elementos para que os indivíduos possam intentar sua simbolização. A chamada cultura de massa aborda o tema pelo mesmo prisma dos demais negócios; que outra coisa se poderia esperar? $\mathrm{O}$ homem moderno quase esquece a morte natural, entretido pelas imagens rasas de catástrofes e assassinatos, reais ou fictícios: os jornais conseguem eclipsar a parte essencial das determinações sociais das mortes que retratam à exaustão e o cinema pode imaginar maldades e violências bem mais agudas e requintadas que as realmente praticadas pelos piores criminosos. Tudo é feito para aliviar a gravidade da morte; tão leve tornou-se que crianças já brincam de matar de verdade: têm sido terrivelmente freqüentes os casos de franco atiradores que mal 
entraram na adolescência. Ainda não era bem assim quando Roberto matou sua família, mas o terror e a morte já assumiam ares de ideal estético; as armas já eram, há muito, objetos fascinantes. Mas Roberto manejava mal o revólver e deflagraram-se o primeiro tiro e a sucessão de mortes...

Passaram-se algumas semanas entre minha primeira leitura do depoimento de Roberto e a leitura do trecho da denúncia em que o promotor narra ao juiz o mesmo episódio, dizendo que Roberto em posse do revólver subiu à parte alta da casa, dirigindo-se ao dormitório de seus pais, oportunidade em que, pela sanha homicida que o acometia, já disparou o primeiro tiro na porta dos aposentos ${ }^{75}$. O promotor, porta-voz da justiça, não pôde encontrar outra resposta para a conduta de Roberto.

Polícia, justiça e psiquiatria encarregaram-se de confirmar a realidade deste primeiro tiro, mas ninguém disse uma palavra para afirmar ou para negar que tenha sido disparado acidentalmente, como declarou Roberto. O caráter involuntário, acidental, deste tiro parece ter sido o elemento mais difícil de compreender, de tudo quanto Roberto contou sobre seu crime; sobre isto, o processo manteve silêncio. Esta era a parte da verdade que não se poderia entender, sob pena de precisar admitir a propiciação social daquele acidente. Para falar deste tiro, a melhor tática seria denunciar nele uma intencionalidade máxima e torpe. Certeiro, então, o golpe desferido pelo promotor e igualmente certeiro o silêncio do defensor.

Roberto, que nunca fôra nem loquaz nem eloqüente, respondia quando perguntado mas não estava em posição de convencer alguém. Diante de seus oponentes só podia pensar em escapar daquelas acusações.

75 Até certo ponto, esta versão conseguiu distrair-me bastante de minha própria hipótese de que Roberto estivesse pensando em suicídio quando apanhou o revólver. Tanto que só recentemente notei que 
Pensava em sair de São Paulo; pensava em morrer. Talvez nunca tenha podido pensar em outras maneiras de defender sua posição, senão se ausentando do confronto: sair andando sem rumo, mudar-se para o litoral, matar-se, matar os oponentes. As palavras nunca lhe valeram; apenas a fuga e a morte.

Como poderiam as palavras valerem àquela família, logo a qualquer um de seus membros, se era próprio de sua condição social que as contradições permanecessem caladas? A justiça zela por assegurar ao réu o direito do contraditório e ampla defesa. Para defender-se, para contraditar o que era dito, tanto na ocasião em que Karin o repreendeu, quanto na ocasião em que o repreenderia pelo tiro acidental, Roberto precisaria possuir palavras para nomear a realidade muito ampla que condicionava sua situação - a insatisfação com os estudos, a busca de um emprego mais compensador, a ansiedade pela vida adulta - refletindo-se em suas condutas. De fato, não as possuía. Como poderia então defender-se quando o promotor o acusou de torpe premeditação?

Depois do crime, mais que nunca, as palavras não poderiam valer à Roberto para dizer sua verdade, para explicar seus atos. Palomba, falando ao Tribunal do Júri, garante que para se poder compreender, psicologicamente, ele [Roberto] tentaria suicídio. Ele não tentaria ficar em pé. Pouco importa quando e como toda a tragédia começou; fato é que, ficando vivo, tentando ficar em pé, Roberto torna-se um monstro - qualquer coisa que faça, exceto matar-se, inclusive falar a verdade, apenas aumenta sua monstruosidade.

Não obstante, todos tentamos ficar em pé, o tempo todo. Nós chamamos de forte, de valente, aquele de nós que consegue sobreviver à 
uma tragédia, que entrega ao cemitério seus mortos e segue vivendo, que procura consertar os estragos de um acidente e toca a vida em frente. Ao contrário, quando algum de nós se mata, então, se somos religiosos, nós o chamamos pecador; se somos psicólogos, nós o chamamos auto-destrutivo; todos o chamamos covarde.

$\mathrm{O}$ individualismo moderno nutre-se dos valentes. Em verdade, portar as bandeiras da igualdade e da liberdade exige de cada um de nós que sejamos mais do que valentes, que sejamos intrépidos: todos os dias, haja o que houver, precisamos encerrar o expediente com competência precisamos sobreviver. Cotidianamente, a sociedade capitalista ilustra os extremos alcançados por esta lógica.

Roberto reagiu com a valentia que lhe era possível aos acontecimentos daquela noite; ele lutou intrepidamente para preservar sua própria viabilidade. Todavia, na lógica de nossa sociedade, a elegância uma espécie de resíduo do ideal da fraternidade - é fundamental: o sucesso depende de que as coisas estejam arranjadas de modo a dispensar a contabilidade de exibir quanto custou a outrem a sobrevivência de cada um; a mínima falha neste quesito é imperdoável.

O crime inteiro de Roberto, desde o mutismo diante da repreensão de Karin até a faxina que procurava ocultar os vestígios das mortes, revelava ao mesmo tempo os extremos de sua fraqueza e de sua valentia; precisamente por isto era trágico. Desnudado em sua vulnerabilidade, desgraçado pelo acaso, sobrepujado em sua argúcia, emudecido, fracassado, Roberto presta-se perfeitamente a encarnar a antítese do homem ideal da modernidade - a carregar suas faltas.

O processo penal e o laudo psiquiátrico trataram de dizer que Roberto não era um dos nossos. Aos poucos, os jornalistas convenceram-se disto, e também eles deixaram de registrar os discursos discordantes. $\mathrm{O}$ 
próprio Roberto delegou, enfim, ao Tribunal a definição de si mesmo, a verdade de seus atos: no dia do julgamento, já não podia afirmar com certeza se teria cometido o crime.

Deixei dito na página 53 que o crime de Roberto desafiava os porta-vozes da sociedade a formular um discurso capaz de compreendê-lo, e que a resposta possível seguiu o caminho de uma dupla idealização desumanizante: as vítimas humanas, reais, foram convertidas em Mãe, Pai e Irmã(o) ideais; Roberto foi convertido em Monstro ideal. O indivíduo moderno, a família burguesa e o sistema social estabelecido foram postos à salvo de qualquer crítica.

Desde então, procurei resgatar os interditos que permitiram à justiça e à psiquiatria construir suas fábulas, e demonstrar como a imprensa fê-las ecoar na sociedade; desde então, falei sobre a resposta que a justiça e a psiquiatria deram, do lugar da sociedade, ao crime praticado por Roberto, no lugar do indivíduo. Mas já na mesma página deixei como questão qual o modelo de homem, de relações humanas, derivava desta fábula juspsiquiátrica, sugerindo que este modelo certamente seria influente na formação das subjetividades, no assujeitamento do indivíduo à ordem social, aos diferentes papéis que prescreve. Não posso tratar esta questão inteira. Mas não deixaria de ensaiar uma conclusão sobre a influência desta fábula no processo de assujeitamento dos indivíduos ao papel social que lhe é prescrito.

Minha leitura dos discursos registrados sobre Roberto, sublinhando o cuidado com que procuravam desacreditar suas razões, suas explicações e, principalmente, suas manifestações afetivas, permitiu conjecturar sobre o modo peculiar como Roberto figurou neles quase sempre como o Outro. Insinua-se destes discursos uma exclusão radical de 
Roberto, para fora do campo da humanidade - isto parece repetir-se em todos os casos célebres de homicídios violentos.

Um homicídio sempre põe em jogo múltiplas situações de relacionamentos interpessoais, desde a relação entre o homicida e a vítima; entre aquele e os manipuladores técnicos e repórteres que se ocuparão do caso; as relações destes últimos entre si, mediadas ou não pelas respectivas instituições das quais são agentes (por exemplo, a relação entre o delegado e o investigador, ou com o juiz, ou entre este e o psiquiatra forense, etc.); entre o homicida e seu advogado; seus familiares e conhecidos; os detentos que compartilham com ele a prisão; até, com certa licença, a "relação" das pessoas comuns com o caso, que apresenta todos os elementos característicos de uma interação social mediante contato indireto ${ }^{76}$.

Todas estas interações permitem supor algum grau de expectativas, comunicação e influência recíproca entre os envolvidos: o interesse das pessoas sobre detalhes da vida do homicida e da vítima, os sentimentos que lhes são devotados, a expectativa sobre a futura conduta do homicida que condiciona a interpretação de suas atitudes, a mobilização para intervir sobre seu destino e/ou para comunicar-lhe o repúdio aos seus crimes.

Estes elementos permeiam todas as interações havidas entre as demais pessoas e o indivíduo criminoso. Quando envolvem pessoas explicitamente investidas da função de porta-voz da sociedade, estas interações mostram-se mais claramente sociais, todavia, como cada um de seus membros porta a voz da sociedade, todas as interações humanas guardam o caráter de uma interação social. Em qualquer interação humana com o homicida, portanto, estarão em jogo aqueles mesmos elementos -

\footnotetext{
${ }^{76}$ Conforme Eva Maria Lakatos, em Sociologia Geral, verbetes interação e contato, do glossário [Lakatos, 1986]
} 
seja num linchamento, numa manifestação popular sobre o curso das investigações, na aplicação da justiça da cadeia, numa entrevista jornalística, nos rituais do processo penal ou no exame psiquiátrico sobre sua sanidade mental.

Como o homicida também porta a voz social, estes elementos encontram nele sua contrapartida: a constante presteza com que se dispõem a comunicar diante da imprensa seus traços pessoais e suas explicações para o crime cometido, sendo comum que se preocupem com isto mesmo antes de perpetrá-lo - como lembram os bilhetes escritos por Mateus da Costa Meira antes de se encaminhar para o cinema onde disparou a esmo contra a platéia ${ }^{77}$. Também é freqüente que o homicida antecipe, em suas declarações, os reproches e os sentimentos que espera sejam-lhe dirigidos pelas pessoas; em geral, fazem isto num tom de constatação que não polemiza quanto à justiça destes reproches e sentimentos, muitas vezes endossando-os de antemão. É comum demonstrarem clara compreensão da lógica que orienta os argumentos passíveis de acatamento por parte de seus interlocutores. Sugeri alhures, para exemplificar isto, que os rapazes de Brasília tinham motivos de ordem social para acreditar sensata e aceitável, como justificativa para o crime que cometeram, suas declarações de que pensavam tratar-se de um mendigo, e não de um índio, o homem que incendiaram ${ }^{78}$ [Ribeiro, 1999].

Que esta interação entre o homicida e as demais pessoas, seus sócios culturais, apresente-se sempre incongruente e falha não significa que não ocorra, mas antes que é preciso atinar com os determinantes de sua sistemática falência - penso tratar-se precisamente da circunstância de que

\footnotetext{
${ }^{77}$ Crime ocorrido em São Paulo, em novembro de 1999.

${ }^{78}$ Crime ocorrido em Brasília, em abril de 1997.
} 
entre ambos se interpõe a pauta social que preconiza para cada envolvido um certo papel a ser desempenhado nesta interação.

Em verdade, isto é o mesmo que ocorre em qualquer interação social; estamos sempre assumindo e desempenhando um certo papel em nossas relações com os outros. O que é específico das interações havidas com o homicida é que os papéis prescritos para ele e para qualquer pessoa que com ele deva se relacionar, são ambos tributários da fábula juspsiquiátrica de um monstro desumano.

Esta fábula prescreve a exclusão como única resposta possível à conduta excludente objetivada pelo homicídio; como a causa desta conduta repousaria, em tese, sobre o indivíduo homicida, descura-se que seu crime possa ter sido já sua resposta possível a uma exclusão prévia que o vitimava. Então, a conduta do homicida na relação com sua vítima, no momento do crime, aparece como exemplo extremo do desconhecimento e exclusão do Outro.

A resposta formulada pela sociedade para o crime admite, na maioria dos casos, que o homicida seja incapaz de empatia, e de reconhecer na vítima uma pessoa que, como ele, sente e deseja. Esta seria, então, a razão porque se tornaria capaz de matar friamente um outro ser humano por motivo fútil, apenas porque atravessou seu caminho, ou para servir como objeto de seus desejos perverso - sem qualquer remorso ou ressonância afetiva para com a sorte de suas vítimas.

O estudo do discurso psiquiátrico sobre Roberto deve ter bastado para colocar sob suspeita estas afirmações; de qualquer modo, bastaria considerar que o homicida é um homem, um ser social: isto torna forçoso admitir que, em primeiro lugar, ele reconhece em sua vítima um ser humano como ele. Se realiza uma cena em que a trata como "coisa", isto deve implicar uma negação daquele reconhecimento primário. 
Não fosse assim, porque haveriam os garotos de Brasília, por exemplo, que procurar um mendigo - um ser humano - para se divertirem ateando-lhe fogo aos pés, em vez de incendiar pneus ou atear fogo a um animal qualquer? Parece evidente que eles tinham uma noção muito clara da classe humana, e queriam atingir precisamente esta classe. Previam exatamente o sofrimento e o desespero que seriam sentidos por seu alvo, apenas que imaginar esta cena, em vez de repugná-los ou apiedá-los, afigurou-se divertido para eles. Caberia perguntar o motivo pelo qual estes rapazes sentiam-se enfadados e carentes de diversão - sentiam-se empobrecidos. Caberia perguntar de onde veio a idéia de que infligir sofrimento e desespero em outrem poderia diverti-los - a eles, rapazes que tinham acesso a todas as formas de divertimento proporcionadas pela cidade e, inclusive, acabavam de sair de uma casa noturna. E ainda, que a melhor espécie de pessoa, a espécie aceitável pela sociedade para ser utilizada neste propósito, seria um dos representantes máximo de seus excluídos, seria um mendigo.

Para confrontar a tese da insensibilidade, da incapacidade de empatia, seria preciso ponderar que o homicida, como qualquer ser humano que conte alguma idade, esteve exposto às noções explícitas de certo e errado, do bem e do mal; também às regras do convívio social, que implicitamente distribuem as possibilidades de conduta entre os indivíduos e as possibilidades de resposta social a estas condutas. As contradições que se insinuam entre aquelas noções e estas regras, o homicida, criado num sistema social mantido ao custo de calar estas contradições, não pode ter palavras para expressar. Talvez este seja o desafio lançado à sociedade por seu crime.

Não pode ser exato que estes homens não experimentem alguma dissonância quando seus atos afrontam tão intensamente os preceitos mais 
explicitamente caros aos seus semelhantes. No caso de Roberto, deve estar evidente que apenas pelo descrédito às suas manifestações afetivas pôde-se dizer que não sentia dor ou remorso pelos homicídios que cometeu, que não recriminava seus próprios atos.

Torna-se necessário supor meandros através dos quais os homicidas, mesmo os mais hediondos, logram adaptar-se ao desempenho de suas ações cruéis, e seguir convivendo consigo mesmos e com seus pares sociais, ao menos até que seus crimes sejam descobertos. Estas considerações levam a pensar que estes indivíduos, para atuarem desta maneira aviltante à humanidade, tenham que possuir arquitetada uma autoimagem compatível com o papel monstruoso que desempenharão diante dos outros homens.

Não fica afirmado aqui que esta auto-imagem pareça-lhe monstruosa ou bela, nem que suas principais peças estejam ajustadas antes do primeiro crime, e menos ainda que sua arquitetura seja obra exclusiva de seu portador. Apenas que deva ser de natureza tal a minimizar o conflito experimentado pelo sujeito quando seus sentimentos, pensamentos ou atos - expressões de sua individualidade - confrontam os limites morais e éticos impostos à coletividade humana. Provavelmente, estes confrontos e suas soluções peculiares através dos ajustes na auto-imagem do indivíduo iniciam-se bem antes que o primeiro crime seja perpetrado, antes até de sua premeditação, se foi premeditado; e podem estar em jogo mesmo nos casos dos crimes chamados impulsivos, debilitando as contenções morais e éticas do impulso que resulta no homicídio. Evidentemente, a família deve desempenhar importante papel na construção desta auto-imagem, mas é preciso bastante cuidado para não lhe atribuir demasiada responsabilidade em suas deformações. 
De toda maneira, deve haver um ajuste dialético entre autoimagem e conduta, operando nestes homicidas como em qualquer pessoa, mas neles como se tivesse um "sinal negativo". Mateus da Costa Meira, quando foi preso, declarou: "Sempre achei que ia matar. Penso nisso desde que cheguei a São Paulo" (então aos 17 anos, quando iniciava seu curso de medicina numa conceituada faculdade, cerca de 6 anos antes de efetivar seu crime). Cabe perguntar que imagem tinha de si este rapaz para achar que se tornaria um assassino, quando até então poderia ser considerado adaptado e bem sucedido, e qualquer pessoa preveria para ele um futuro bem diverso.

Encontrar uma explicação para seus disparos contra a platéia do cinema não pode significar encontrar o melhor nome para descrever seu afastamento da realidade compartilhada pelas pessoas à sua volta. De fato, explicar seu crime significa compreender como chegou a ter uma autoimagem tão negativa, discrepante daquela que seria esperada levando-se em conta seus atributos e realizações até aquele momento. Causa estranheza pensar que durante os seis anos seguintes nada o reconduziu para um prognóstico mais positivo sobre si mesmo, ao contrário, sua negatividade parece ter sido aguçada até o ponto dele finalmente tomar como digno de si o ato de matar, aceitando todas as conseqüências disto - sendo uma delas a correção, afinal, daquela discrepância.

Advirto, porém, que não fica implícita aqui a afirmação de que o indivíduo conforme-se completamente a esta auto-imagem malévola, que o impele a aceitar desempenhar um papel monstruoso; ao contrário, enfatizo que um conflito residual deva sempre obstar sua plena aceitação, fazendo o sujeito retroceder diante de uma ou outra atrocidade. É irresistível invocar em defesa disto o caráter plausivelmente metafórico dos disparos de Mateus contra o espelho, momentos antes de substituir drasticamente sua imagem pública, de pessoa para monstro. 
Há quem diga que estes crimes espetaculares são cometidos por pessoas presunçosas em busca de fama; penso que poucas explicações poderiam ser menos coerentes. Antes, parece-me claro que apenas um sujeito descrente de sua capacidade para angariar o reconhecimento (noutra palavra: o amor) de seus pares sociais mediante atitudes benignas poderia aceitar a atenção horrorizada que um crime monstruoso pode propiciar.

Se auto-imagem e conduta ajustam-se reciprocamente, permitindo ao indivíduo prosseguir em busca da satisfação de suas necessidades sociais $^{79}$ - como a necessidade de afeto e aprovação, ou de atenção e confirmação existencial - então é preciso admitir que a sociedade seja eivada por algum sistema congruente, apropriado para atender, no caso destes homicidas, uma dinâmica individual assim marcada por um sinal maligno. Em outras palavras, se alguns homens conduzem-se como monstros no meio social, deve-se supor que o meio social os alimente deve haver um nicho social que lhes seja propício ${ }^{80}$.

\footnotetext{
${ }^{79}$ Conforme a discussão precedente, às páginas 242 e seguintes.

${ }^{80} \mathrm{O}$ conceito biológico de nicho, sabemos, refere-se amplamente à interface entre o modo de vida de uma espécie e as condições oferecidas pelo ambiente para a satisfação de suas necessidades. Mais que adaptação, este termo sugere oportunismo; mais que competição, sugere um quadro ambíguo de exclusão/inclusão. $\mathrm{O}$ uso metafórico deste conceito pareceu-me particularmente pertinente porque ele não expressa qualquer noção de territorialidade ou de segregação entre as espécies (como é o caso do conceito de habitat); caso contrário, a comparação pretendida poderia transmitir a idéia de gueto, ou submundo, ou ainda de subcultura marginal, quando a intenção é oposta: adaptado para o contexto social, o conceito de nicho (então, o nicho social) deve expressar a interface dinâmica, entretecida e fluida, entre os modos de atuação dos indivíduos e as condições sistemáticas da sociedade, que permite sejam satisfeitas em algum grau as necessidades de ambos os pólos, particularmente as necessidades de ordem gregária: no que concerne à sociedade, a necessidade de preservar os sistemas ideológicos que sustentam os padrões de desempenho dos papéis sociais; no que concerne ao indivíduo, desde as necessidades de afeto e aprovação, que exigem para sua satisfação uma relação amorosa entre indivíduo e grupo, até as de pertencimento, participação e reconhecimento no grupo social, que não fazem referência ao sentido desta relação, podendo esperar-se que seja eficiente em atender estas necessidades mesmo quando não seja amorosa.
} 
Se pudermos considerar auto-imagem e conduta como ocupando, no plano individual, posições simétricas às das representações e respostas sociais, então teremos que imaginar um elemento capaz de promover a efetiva tradução de um plano noutro, ou seja, de oferecer ao indivíduo uma forma validada socialmente para atuar em busca da satisfação de suas necessidades observando os limites impostos pela imagem construída de si, e oferecer aos seus sócios culturais um gabarito para a interpretação de seus atos que isente a todos os demais de responsabilidade neles e, simultaneamente, siga garantindo a validade social da forma empregada em sua conduta. A idéia de modelo social preenche ambas as exigências.

Penso que o modelo social do assassino psicopata constitui-se em modelo de conduta assimilável por indivíduos dotados de uma autoimagem de cunho particularmente malígno, seja ela antecedente, conseqüente ou independente da prática de um crime cruel. Mas este modelo de monstro desdobra-se no modelo de homem: quando responde ao homicídio violento desconfirmando a humanidade de seu autor, excluindo do discurso social qualquer alusão às suas fraquezas, aos seus conflitos, seus desejos e sentimentos benignos, às suas demonstrações de angústia; a sociedade opera uma mutilação na pessoa integral, boa e má, do homicida. O criminoso real é excluído da cena; vem substituí-lo então a figura de um monstro fabuloso.

A fábula juspsiquiátrica, sendo proclamada pela voz social do tribunal, valida ao mesmo tempo outra exclusão igualmente necessária à sua construção: cada indivíduo obrigado a relacionar-se com o homicida deve excluir de suas representações a mais ligeira compreensão, a mínima empatia, a menor simpatia, despertada em si mesmo pelo contato com o Outro. Depura-se assim o modelo do homem bom - em verdade, o julgador 
excludente, mutilador da humanidade do sujeito criminoso que, para fazer seu trabalho, precisa também mutilar sua própria humanidade.

Incutido em cada membro da sociedade, este modelo empobrece em todos a capacidade humana de sustentar o pensamento sobre a contradição e o conflito, de criticar a si mesmo e às instituições que criou, de compreender empaticamente outro ser humano, de elaborar seus próprios desejos e temores, de suportar a angústia. Este modelo preconiza a validade de responder ao outro excluindo-o e mutilando-o, sempre quando sua conduta nos contradite, nos contrarie, nos angustie. A construção e a validação da fábula juspsiquiátrica sobre o homicida violento fornecem um modelo social de conduta que perverte as relações de alteridade; este é o modelo desdobrado nos papéis do monstro psicopata e do homem bom.

Nossa justiça e nossos saberes psi produziram já tanta abundância e variedade de monstros modelares, e nossa tecnologia já os divulgou em tal escala, que qualquer indivíduo participante de nossa cultura, por mais bizarra que resultasse sua auto-imagem, não teria dificuldade em encontrar um sob medida para as suas necessidades bastaria circular um pouco pelos canais da TV, no cinema, nas páginas policiais ou na internet. Há quem alimente e cultue estes monstros, e sempre haverá quem procure orientar a própria conduta inspirando-se em seu modelo. Uns, parecem encontrar neles um ideal estético para suas vidas; outros, uma alternativa de interação com o ambiente social.

A fábula vale, igualmente, como gabarito para responder ao mais singular dos casos; aparadas algumas arestas, qualquer homicida pode sempre ser ajustado à imagem de um monstro desumano. Esta operação é facilitada quando o homicida efetivamente espelhou-se na fábula, mas será possível sempre: é da natureza desta fábula servir a substituir a figura humana do criminoso... amplia-se assim nossa galeria de monstros. 
Consola-me a idéia de que este estudo tenha conseguido retirar daí a imagem de Roberto. Parece-me importante desmantelar os nichos onde a sociedade moderna tem cultuado seus monstros modelares, e creio que não há meio mais eficaz de fazê-lo que resgatar a humanidade daqueles que ali foram entronizados. Mas, melhor que qualquer um, sei que não há nisto consolo bastante para aplacar a angústia suscitada pelas páginas anteriores.

Talvez fosse mais confortador fazer sugestões morais para a família, a justiça, a psiquiatria, a imprensa, o cinema... mas não seria um conforto honesto. Não vejo, sinceramente, caminho para remediar o sofrimento humano que possa desviar da subversão do atual ordenamento das relações humanas, que possa prescindir de uma transformação radical do sistema sócio-econômico que regula a formação e a vida de cada indivíduo do mundo contemporâneo. Assim, aos agentes de cada uma destas instâncias sociais, digo apenas: procurem agir com benevolência e sinceridade; façam isto para subverter a regra de egoísmo e dissimulação que sustenta a exploração e a opressão do homem.

Penso que a benevolência e a sinceridade sejam algumas das atitudes mais revolucionárias que se possa adotar hoje em dia, precisamente porque fazem adiar os julgamentos: quando tudo nos convida a desprezar os fracassados e a enaltecer os vitoriosos, é preciso estancar por um momento para atentar às regras do jogo. A benevolência, permitindo perdoar as culpas do Outro, permite que o aceitemos em sua singularidade, que conheçamos suas razões e, então, as regras que as condicionam. A sinceridade é benevolência conosco: é a aceitação integral de quem somos, incluindo nossas fraquezas e culpas, nosso poder e responsabilidade. A sinceridade permite a empatia e a identificação com o fracassado e com o 
vitorioso, simultaneamente; disto resulta a capacidade de assumir nossa responsabilidade na reformulação das regras, na recriação do mundo.

As diferentes escolas da psicologia produziram farta nomenclatura para referir estas coisas; não as explicito propositadamente, para melhor permitir à cada leitor utilizar aquela com a qual tenha maior afinidade. É relativamente fácil aplicá-las aos casos mais brandos de culpa e fracasso; mas é bem difícil quando se trata de um caso extremo como o de Roberto, de sua família e dos representantes sociais que dele se ocuparam. Contudo, espero ter conseguido demonstrar tratar-se de um procedimento possível e frutífero para a compreensão crítica e para a transformação do nosso mundo, onde estes casos extremos têm sido freqüentes e até banalizados.

Disse antes que este estudo sustentava-se sobre uma profissão de fé. À psicologia, penso, resta o trabalho de conclamar cada homem à construção de um mundo mais acolhedor e efetivamente mais humano, para si mesmo e para todos os outros, ao mesmo tempo que denuncia a ideologia que lança aos ombros dos indivíduos a responsabilidade pelas contradições e destemperos da sociedade. Evidentemente, acredito que isto seja útil à construção de uma nova ética das relações humanas: o fortalecimento dos vínculos amorosos, o exercício da solidariedade, a aceitação do outro, a serenidade diante do desconhecido e da angústia que ele provoca, a responsabilidade social. 


\section{Pós-escrito}

Horas depois de dar por concluída esta dissertação, voltou-me à lembrança uma idéia ocorrida cerca de três anos antes: dedicá-la à Arakcy Martins Rodrigues, professora que mal conheci. Na época, eu seguia seu curso Indivíduo, Grupo e Sociedade [IP-USP/ PST-5743, 1997], e tinha lido uma entrevista que dera em 1981 à Olgária Matos e Fernando Mesquita, comentando certo acontecimento de 1955: moradores de um lugarejo chamado Catulé, no interior de Minas Gerais, acreditando que o demônio apossara-se de alguns dentre eles, mataram quatro crianças e feriram gravemente outras pessoas da comunidade. Os dois líderes religiosos do grupo foram mortos pela polícia.

Os comentários de Arakcy sobre o caso do Catulé soaram-me como encorajamento ao meu próprio modo de abordar o tema dos homicídios violentos. Senti por ela imensa simpatia - ternura, até; e também senti dó: parecia amargurar-se com o que dizia. Infortunados desencontros impediram-me de conversar com ela a respeito do assunto, até que ela morreu. Prossegui o estudo e redigi seu relato sem mais lembrar dos sentimentos que a leitura daquela entrevista havia provocado em mim; talvez por isto não tenha podido referir antes sua contribuição para minha análise do caso de Roberto.

Reli agora a entrevista; as palavras finais de Arakcy soaram-me como a chave necessária a fechar minha própria dissertação. É bom, porque permite corrigir meu lapso a tempo de trazer para cá a sua voz:

"As idéias estão bem atropeladas, mas acho que deu para transmitir (...) que fenômenos muito atípicos e aparentemente caóticos demais podem ser, muitas vezes, uma condensação de situações muito dignas de estudo mas que se apresentam, infelizmente, na forma de catástrofes assustadoras das quais todos, até os cientistas, têm que fugir" [Rodrigues, 1981]. 


\section{Bibliografia}

Adorno, Sérgio. Crime, Justiça Penal e Desigualdade Jurídica. As mortes que se contam no Tribunal do Júri. Revista USP, 21 [132:151], 1994

Adorno, Theodor W. \& Horkheimer, M. "Sociedade" e "Indivíduo" In: Temas Básicos de Psicologia [25:60]. São Paulo: Cultrix, 1978

Albuquerque, J.A.G. O louco, entre o juiz e o médico. In: Metáforas da Desordem [81:96]. Rio de Janeiro: Paz e Terra, 1978

Arendt, Hannah. A Condição Humana. (tradução de Roberto Raposo) Rio de Janeiro: Forense Universitária, 1987

Benevides, Maria Victória. Violência, povo e polícia. Violência urbana no noticiário de imprensa. São Paulo: Brasiliense, 1983

Berger, P.L. \& Luckmann, T. A Construção Social da Realidade. Tratado de Sociologia do Conhecimento. (tradução de Floriano Souza Fernandes) Petrópolis: Vozes, 1978

Birman, Joel. O lugar do psíquico na experiência da loucura. Ciência-Hoje, 6 [30:36], 1983

Bleger, José. Psicologia da Conduta. Porto Alegre: Artes Médicas, 1984

Boltanski, Luc. Os executivos autodidatas (tradução de Arakcy Martins Rodrigues).

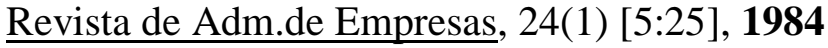

Brandão, Junito de Souza. Mitologia Grega III. Petrópolis: Vozes ( $6^{\text {a }}$ edição), 1995

Butcher, James Neal. Psicologia do anormal. São Paulo: Cultrix, 1975

Canevacci, Massimo (Introdução e Organização). Dialética da Família. Gênese, estrutura e dinâmica de uma instituição repressiva (tradução de Carlos Nelson Coutinho). São Paulo: Brasiliense (4 edição), 1981

Castaldi, Carlo e outros. O Demônio do Catulé. In: Estudos de Sociologia e História. São Paulo: Anhembi, 1957

Corrêa, Mariza. Morte em Família.Representações jurídicas de papéis sexuais. Rio de Janeiro: Graal, 1983

Damergian, Sueli. Entre a vida e a morte: a violência contra a infância nos grandes centros urbanos. In: Steiner, M.H.F. (org) Quando a criança não tem vez: violência e desamor. São Paulo: Pioneira, 1986

Feldman, M. Philip. Comportamento Criminoso. Uma análise psicológica (tradução de Áurea Weissenberg). Rio de Janeiro: Zahar, 1979 
Figueiredo, Luís Cláudio M. Revisitando as Psicologias. Da epistemologia à ética das práticas e discursos psicológicos. São Paulo: Educ; Petrópolis: Vozes, 1996

Foucault e Heidegger. A ética e as formas históricas do habitar (e do não habitar). Tempo Social: Ver. Sociologia da USP, 7 (1-2) [139:149]. São Paulo, 1995

Foucault, Michel. As ciências humanas. In: As palavras e as coisas [447-501]. São Paulo: Martins Fontes, 1966

Os assassinatos que se conta. In: Foucault, M. (org.), Eu, Pierre Rivière, que degolei minha mãe, minha irmã e meu irmão (tradução de Denize Lezan de Almeida). Rio de Janeiro: Graal, 1977

1977

Vigiar e Punir. História da violência nas prisões. Petrópolis: Vozes, Microfísica do poder. Rio de Janeiro: Graal, 1979

O que é iluminismo. In: Escobar, C.H. (org) Michel Foucaul. $O$ dossier. [103:112]. Rio de Janeiro: Taurus, 1984

O que é um autor? Lisboa: Ed. Veja, Col. Passagens, 1992

A Ordem do Discurso. Aula inaugural no College de France, pronunciada em 2 de dezembro de 1970 (tradução de Laura Fraga A. Sampaio). São Paulo: Loyola (2 ${ }^{\text {a }}$ edição), 1996

Gonçalves $\mathbf{F}^{\mathbf{0}}$, José Moura. Passagem para Vila Joanisa. Uma introdução ao problema da humilhação social. Dissertação de mestrado apresentada ao IP-USP/ PST. São Paulo, 1995

Hare, R.D. Psicopatia: Teoria e Pesquisa. (tradução de Cláudia Moraes Rego). Rio de Janeiro: LTC, 1973

Hentig, H.V. El asesinato. (tradução de José Maria Rodrigues Devesa) Madrid: Espasa, 1962

Holland, Ray. Eu e contexto social. (tradução de Angela Melim) Rio de Janeiro: Zahar, 1979

Hoy, David Couzens (org). Foucault. Buenos Aires: Nueva Visión, 1988

Jaccard, R. Linguagem e poder: rotulagem psiquiátrica e invalidação social. In: $\underline{A}$ Loucura. Rio de Janeiro: Zahar, 1981

Klein, Melanie \& Riviere, Joan. Amor, ódio e reparação. (tradução de Maria Helena Senise) São Paulo: Edusp, 1975

Lacan, Jacques. Kant com Sade. (tradução de Jussara Falek Brauer, inédita), 1963 
Maingueneau, Dominique. Novas Tendências em Análise do Discurso. São Paulo: Pontes, 1989

Maisonneuve, Jean. Introdução à Psicossociologia. São Paulo: Edusp, 1977 A Psicologia Social. São Paulo: Martins Fontes, 1988

Martins, José de Souza. Linchamentos: a vida por um fio. Travessia: Revista do Migrante, 4 [21:28], 1989

Mázzaro, Antonio Cláudio. Investigação Clínica da Personalidade de Adolescentes Homicidas através do Procedimento de Desenhos-Estórias. Dissertação de mestrado, PUCCAMP. Campinas, 1984

Mirabete, Júlio Fabbrini. Manual de Direito Penal. São Paulo: Atlas, 1996

Monteiro, Antonio Lopes. Crimes Hediondos. São Paulo: Saraiva (5 ${ }^{\mathrm{a}}$ edição), 1997

Paiva, Luiz Miller de. Crime:Psicanálise Psicossomática. Tanatismo (Volume 1). Rio de Janeiro: Imago, 1981

Palomba, Guido Arturo. Loucura e Crime. São Paulo: Fiuza, 1996

Patto, Maria Helena Souza. A produção do fracasso escolar: histórias de submissão e rebeldia. São Paulo: Casa do Psicólogo, 2000

Peter, Jean-Pierre \& Favret, Jeanne. O Animal, o Louco, a Morte. In: Foucault, M. (org.), Eu, Pierre Rivière, que degolei minha mãe, minha irmã e meu irmão (tradução de Denize Lezan de Almeida). Rio de Janeiro: Graal, 1977

Ramalho, José Ricardo. Mundo do Crime: a ordem pelo avesso. Rio de Janeiro: Graal, 1983

Rascovsky, A. El Filicídio. Buenos Aires: Orion, 1973

Rech, Daniel. A violência, o crime e a justiça. Travessia: Revista do Migrante, 4 [29:32], 1989

Reik, T. El asesino desconocido. Buenos Aires: El Ateneo, 1943

Ribeiro, Sandra M.P. O fenômeno social do homicídio estarrecedor. Pulsional: Revista de Psicanálise, 116/117 [134:147], 1999

Rivers, William L. \& Schramm, Wilbur. Responsabilidade na comunicação de massa. (tradução de Muniz Sodré e Roberto Lent). Edições Bloch, s/d.

Rocha, Luiz Carlos da. Vidas Presas: uma tentativa de compreender a tragédia da criminalidade junto às suas personagens oprimidas. Dissertação de mestrado apresentada ao IP-USP/ PST. São Paulo, 1984

Rodrigues, Arakcy Martins. $O$ do Catulé e outros demônios. In: Almanaque Cadernos de Literatura e Ensaio, 12 [24:37]. São Paulo: Brasiliense, 1981 
Schneider, Kurt. Las Personalidades Psicopáticas. (tradução de Bartolomé Llopis) Madrid: Morata, 1943

Sodré, Muniz. A comunicação do grotesco. Um ensaio sobre a cultura de massa no Brasil. Petrópolis: Vozes, 1983

Souza, Lídio de. Olho por olho, dente por dente: representação de justiça e identidade social. Tese de doutoramento apresentada ao IP-USP. São Paulo, 1995

Stein, Conrad. As erínias de uma mãe. Ensaio sobre o ódio. (tradução de Nelson da Silva Jr.) São Paulo: Escuta, 1988

Sutherland, Edwin H. Princípios de Criminologia. (tradução de Asdrúbal Mendes Gonçalves) São Paulo: Ed. Martins, 1949

Tassara, Eda T. de Oliveira \& Damergian, Sueli. Para um novo humanismo. Contribuições da Psicologia Social. Estudos Avançados, 10(28) [291:316], 1996

Vernant, Jean-Pierre. A morte nos olhos. Figurações do Outro na Grécia Antiga. Ártemis, Gorgó. (tradução de Clóvis Marques) Rio de Janeiro: Zahar, s/d. 
Anexos 
ANEXO I: Laudo pericial de transcrição da entrevista concedida por Roberto a diversos repórteres do "Programa Cidade Aberta"

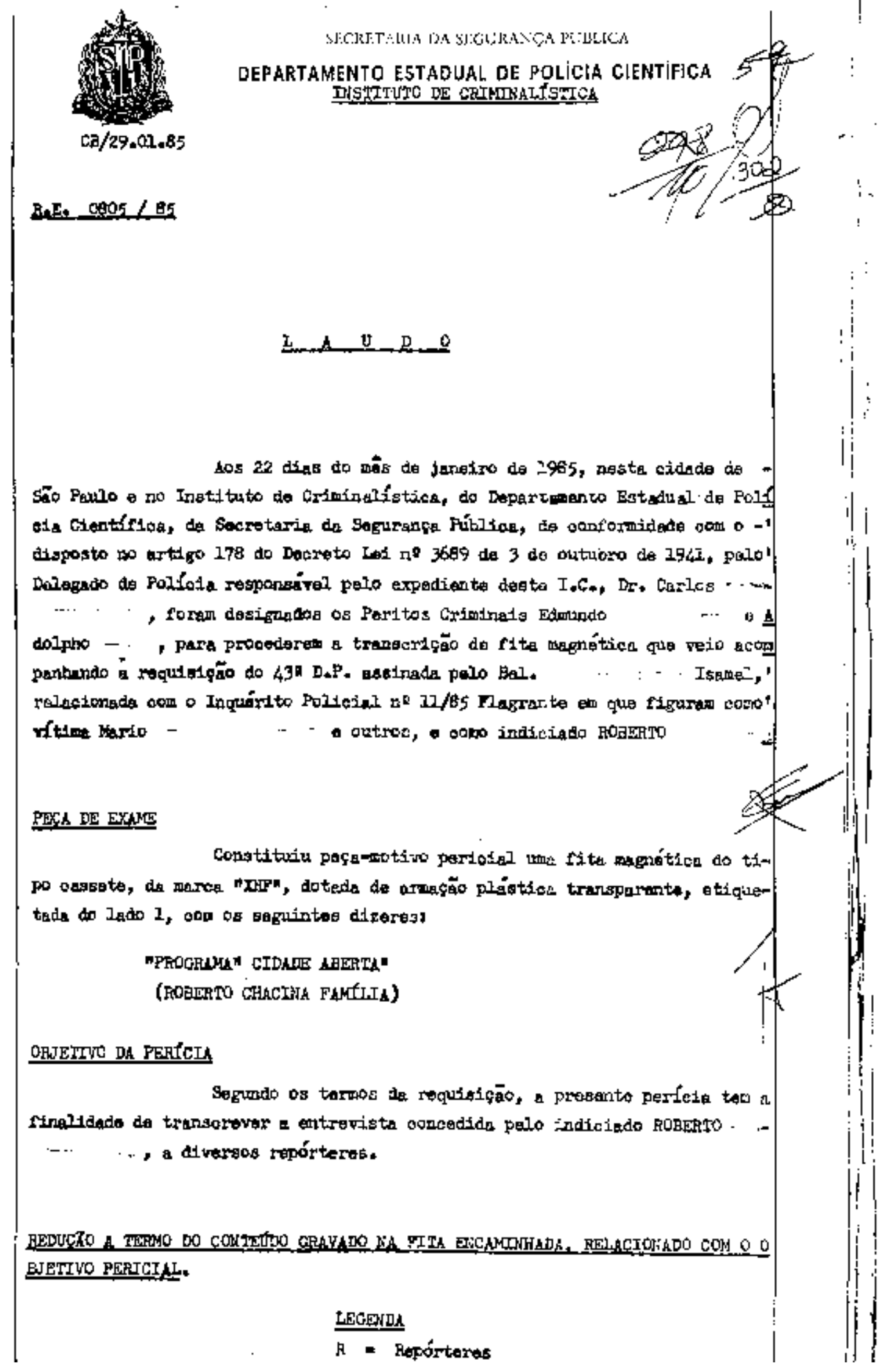



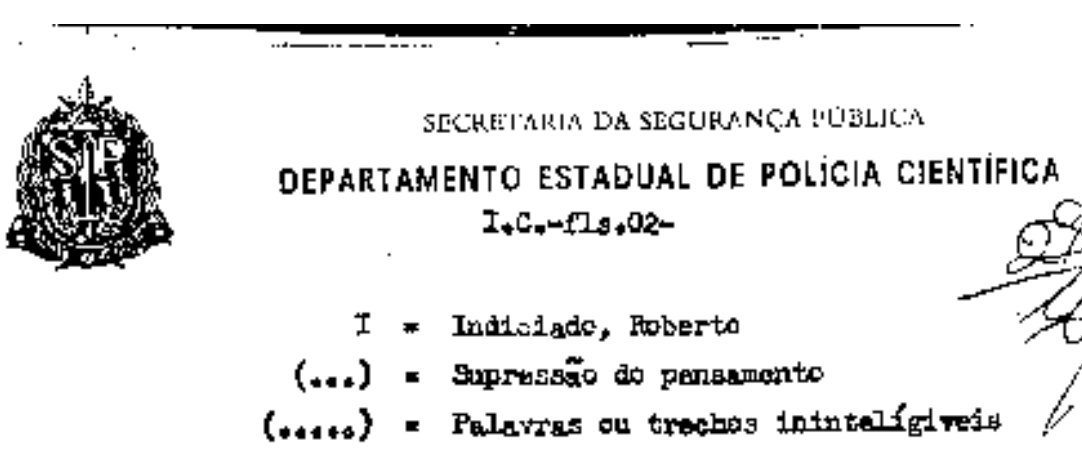

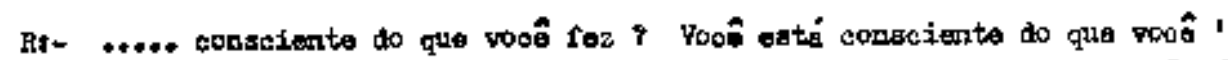

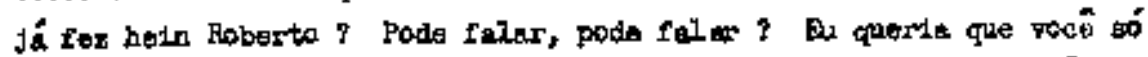

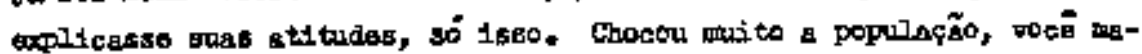

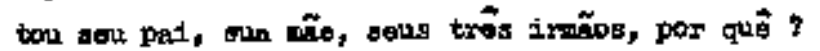

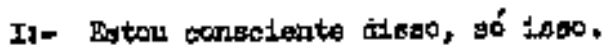

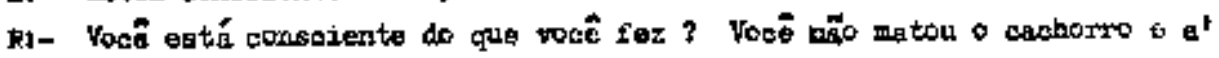

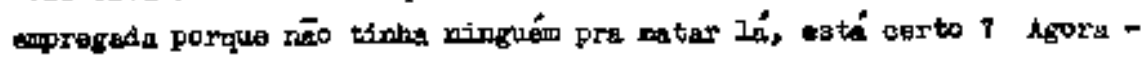

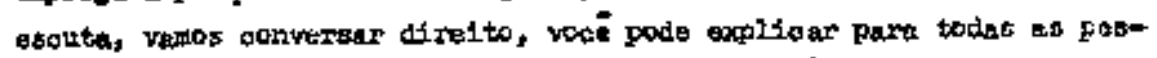

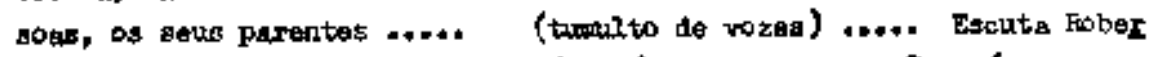

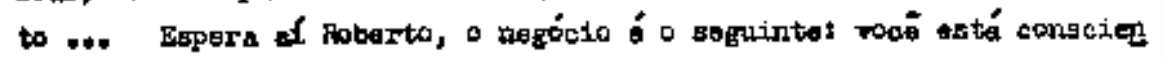
to do que você $\mathrm{foz} T$

In IYre a wo razendo o favor.

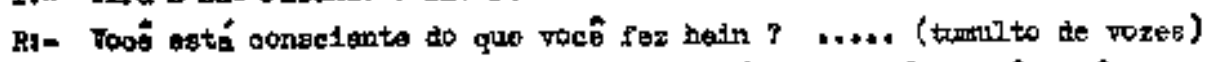

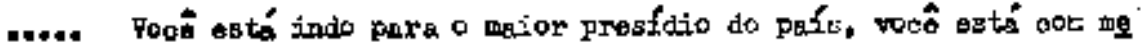
to ? ..... medo 柏 quث ?

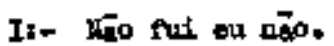

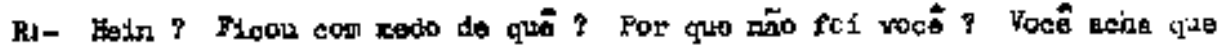

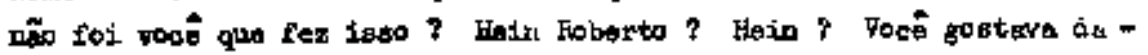

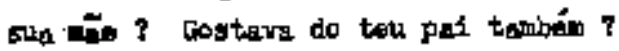

I1- toritos, de todos.

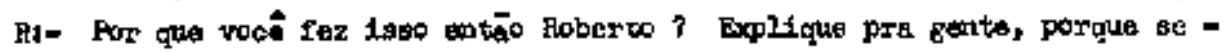

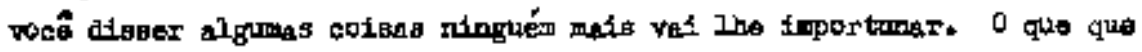
acontengu recimanta cor vacê $\mathrm{P}$.....

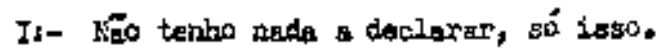

R!. .....

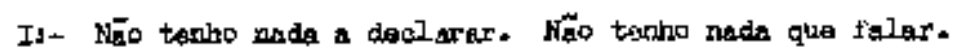

R:- Yock món gente o qua acontecer con voci aqui ? .....

I:- POيso in embore?

Ri- Ispera foberto, Você eatá tranquilo koberto ?

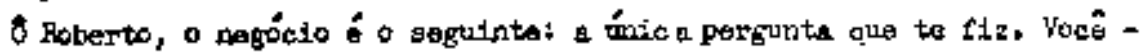

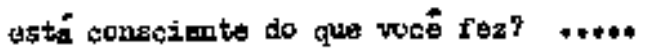

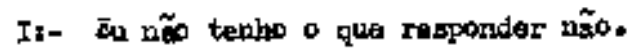

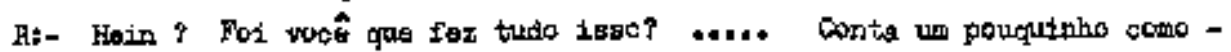

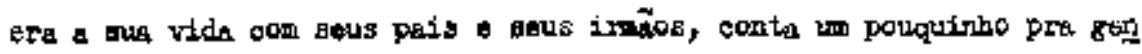
ta. Era mutio zoxim ?

It Ha taino mada a deol zar no. 


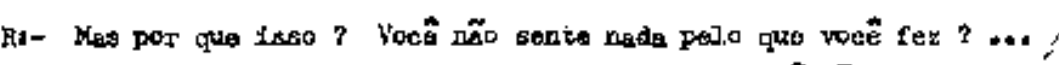

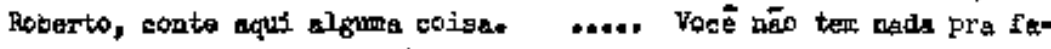

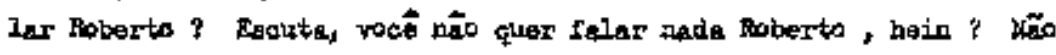
vol falur nade 7 J Iar rada liaberto.

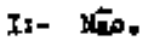

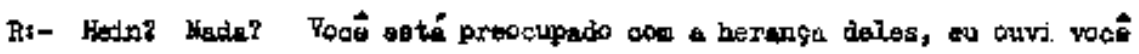

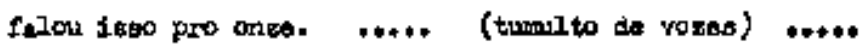

I1- Mós năb temos berts.

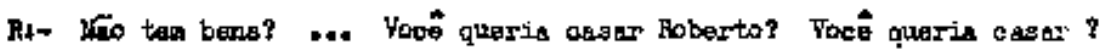

Ir = queria.

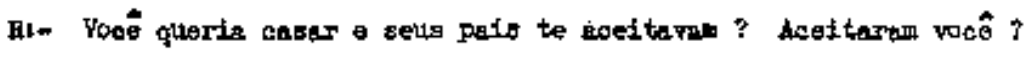

It- Nagitersm,

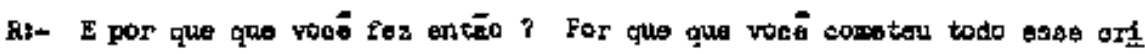

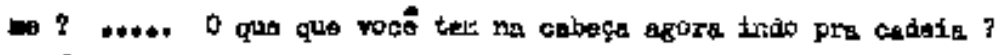

Ii- Estí tado entrolado.

B: $=$ Nodn $?$

Ii- Eston musto atrapsithado.

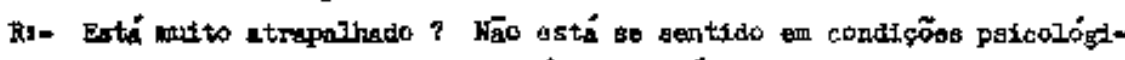

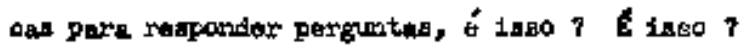

II- 撂.

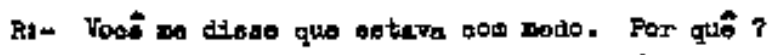

I3* Howiso do que val acontioer hora, ní ?

Ra- 0 qua pedie heontoger 3

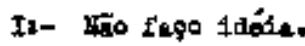

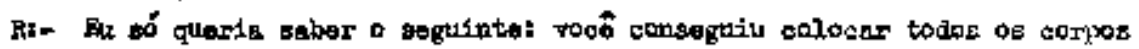
demtro do carro sozinho it

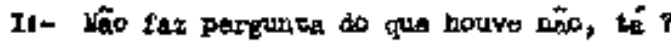

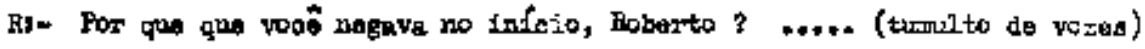

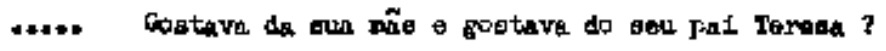

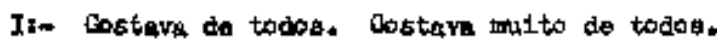

at- Por que voeâ fez 1sto, por qute vocô pratícou o crime?

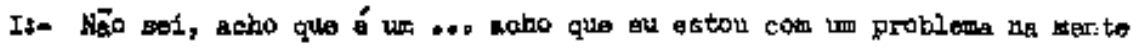
nolo qué isso.

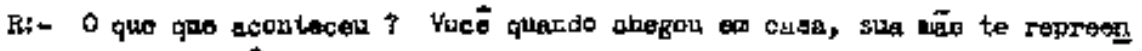
dot que veet floot furiogo, fot por 1980.

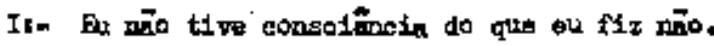

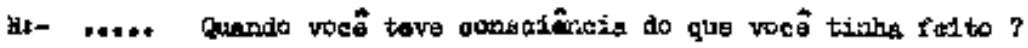

II- Dopais que acabor tudo.

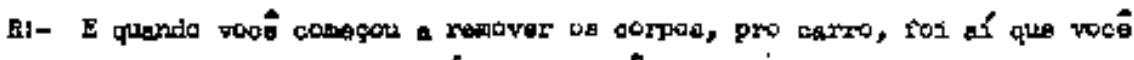

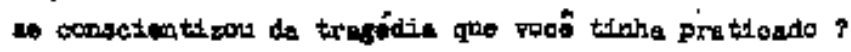




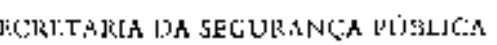
DEPARTAMENTO estadual DE POLICIA cientifica,

$I . \mathrm{C},-\mathrm{rls}, \mathrm{OL}$

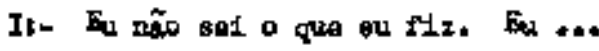

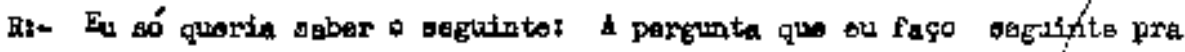
voose, é esaat

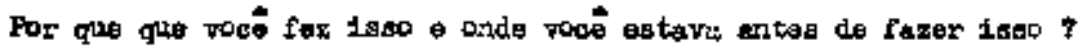

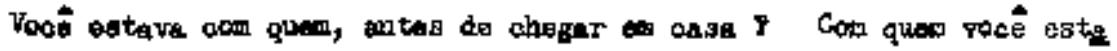
va?

Ii: Estara na chap de ure amigs.

Rt:- Soi , Tus nemorede.

It: Isso.

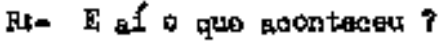

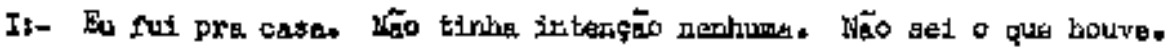

Et- Vooê está arropindido ?

Ii- Bartarte, atuito.

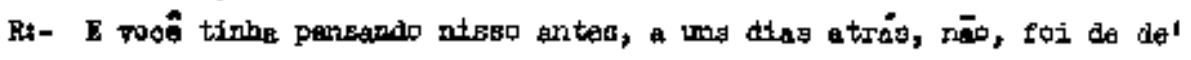
momerto ?

I1- Foi de momente, fol ha hozk.

It- E o nagóclo da harange, Robarto, qus pooe fala?

II- Bu não quaro hornaça.

Rt:- Who tom nada?

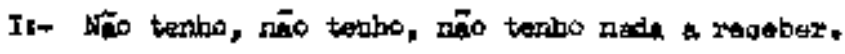

at- Estara pretisando de dinhexio?

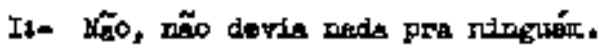

Ri- has voö ia oasser, á̉ ?

II- Lh, mas quguto 1aso a gente in dividtr tudo am dois.

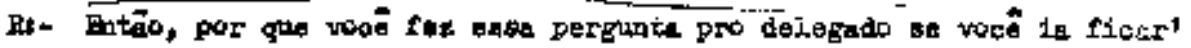
gat a herança do ñ̃o ?

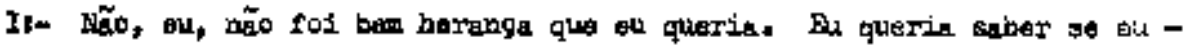
podie pegar une parto do qui tom, que a gente posecize, pre poder I

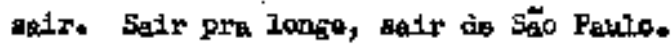

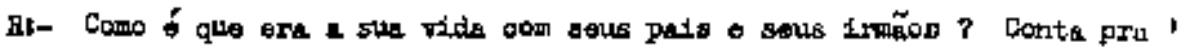
genta um pouruluino.

Ij- Exa nistrit.

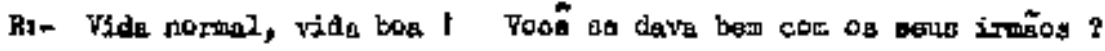

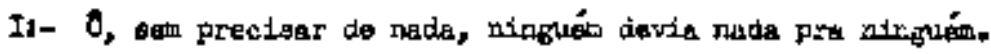

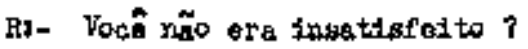

It- Wấ, ora beom satisifolto.

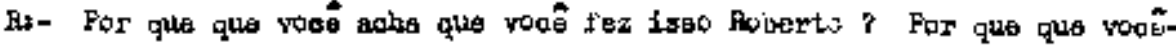
neha, você tam consciência dïse ? .....

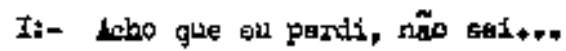

Ka- Voob chogou on pensar risso? 


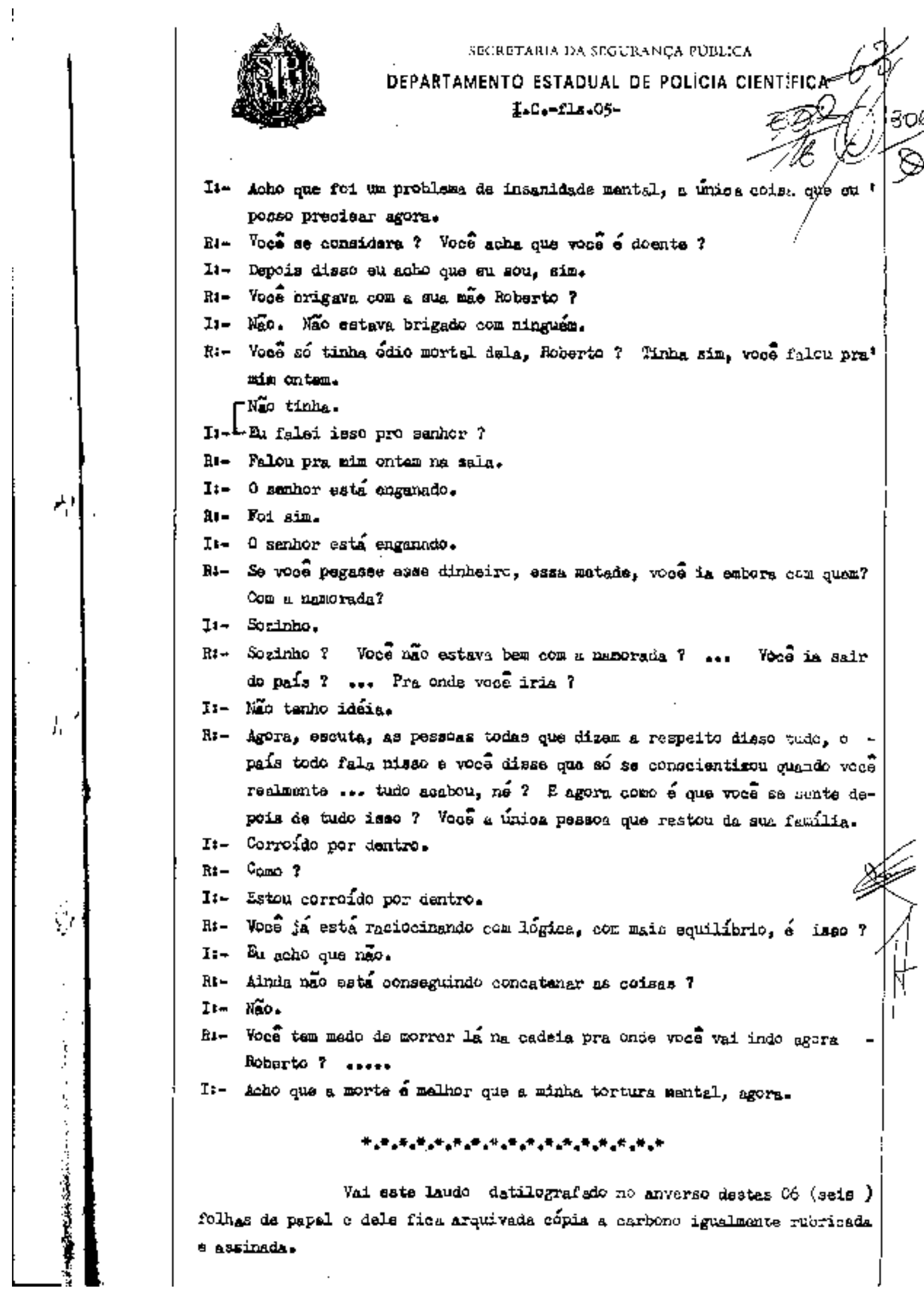


ANEXO II: Reportagens publicadas pelos jornais "Notícias Populares" e "Folha de São Paulo" no dia 13 de janeiro de 1985 (domingo seguinte ao crime)

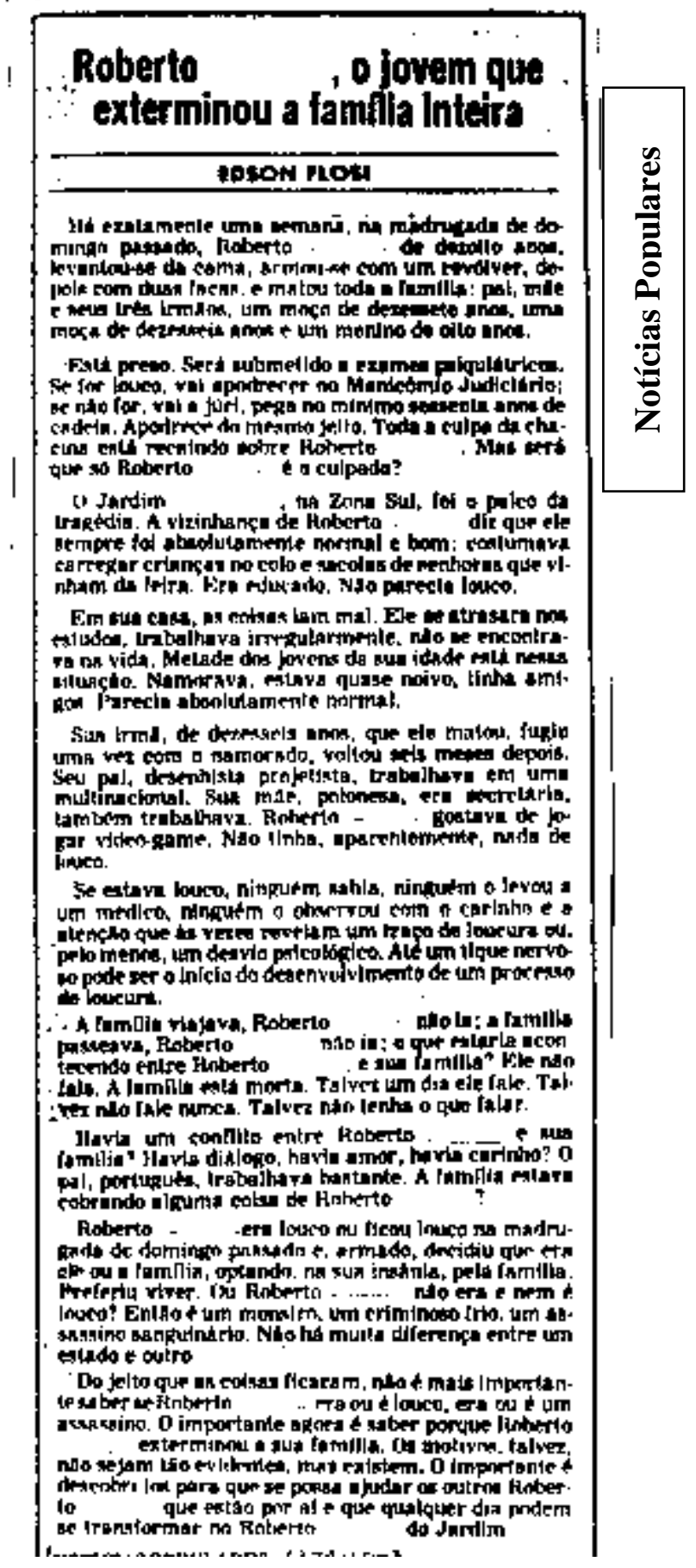




\section{Liberdade, receita para curar' os conflitos familiares}

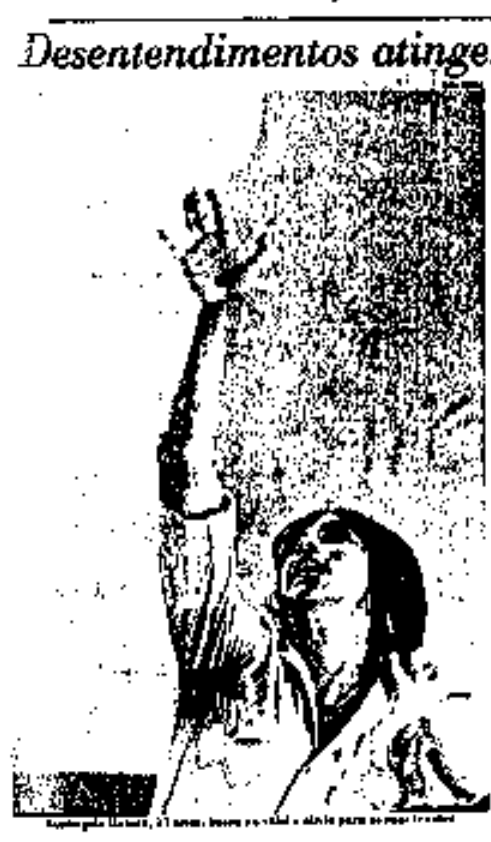

Violência é uma exceção, afirma antropólogo gaúcho 等 (n)

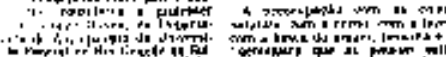

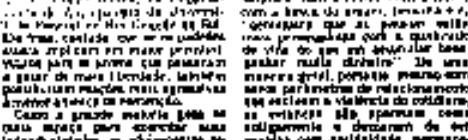
然 (t)

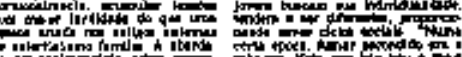

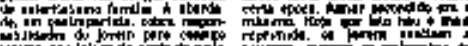

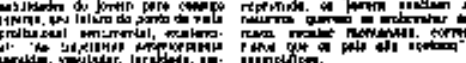

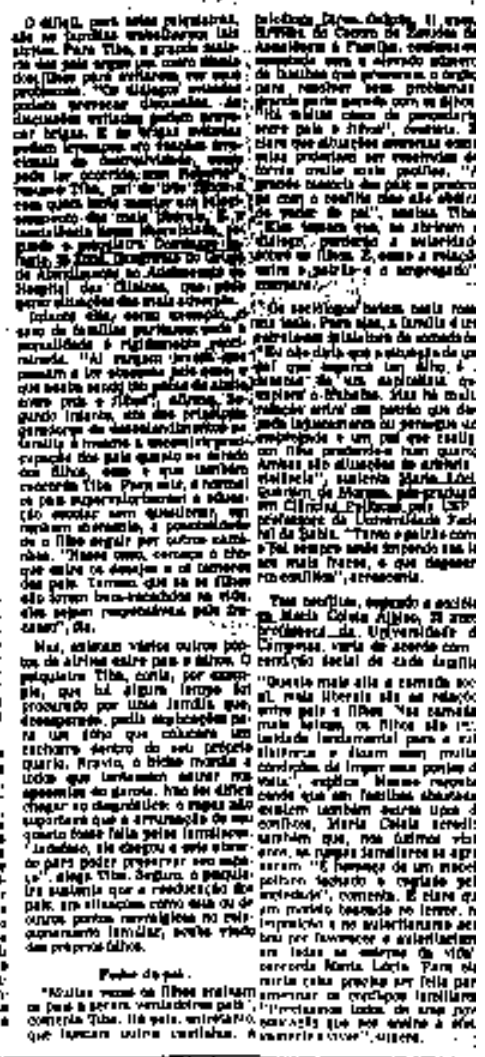

Folha de São Paulo 
ANEXO III: Reportagem publicada pelo jornal "Folha de São Paulo" em

\author{
22 de agosto de 1987 (três dias após a condenação de Roberto pelo
}

Tribunal do Júri).

\title{
Neurologista afirma que epilepsia de assassino da família não existe
}

\author{
On feporidgen Laça \\ - de Novo Yark
}

I nuroleginca tiathe Jout Rring id Cempos, 37, cheile do setor de

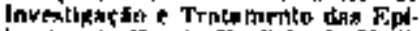

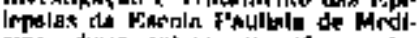
cins, ditwe ntorm gto ThAo exiple. "itn to nhum trutedo to munda inteirv". a "eplleminla condulopdilica"

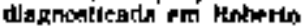

File nflo sitheou reprecillcam-air $\vec{r}$ inuilo eprementado pela prrito Subda Artura Palomba, por dracthinectio, mas a terrainalogla

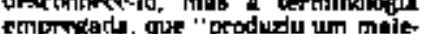
strpinkath, que "peodusu um moit. foro maior que

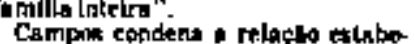

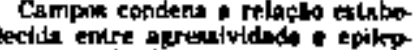
lectid entre agrunitwidad epikg utculo passadg", que reaviva o pre-

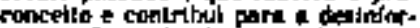

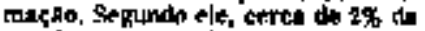
populacis t/m tyllepalia, numbo que

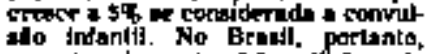
apraximadamente 2.0 milhters de

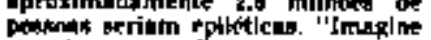
a mal que ate ditantalico broduzlu a mal que aise ditantalico brodurlu nin puppingdo

O nurohingla diz que a egreairt. dade nia e chractertidica do pacienie epiletico e que cribe agreulva "aboolutemenle nra", Ele oftreil

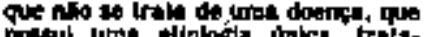

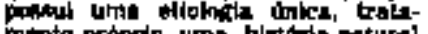
monto proprito, uma hitarie neturel - diagnarileso unicos, mite de uni undromis $-\mathrm{em}$ que, no coatricio, noce fulores cha ditereniea.

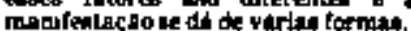

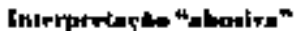

Pirn a rxurolndiala Michel Pietre Lisan, 51. professor thtular de Faculdade de Mextcina de Kubeirsa frreto

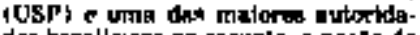
des branlleirat od assunlo, a nocha de

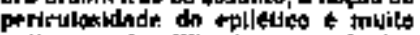

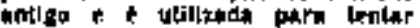
oxplles horlickdion inceptiedvela.

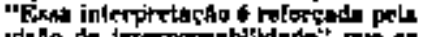

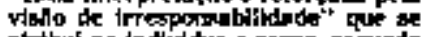
atribuf no indi widwo e nerve, argurda

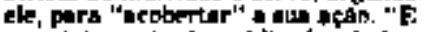

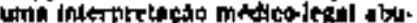

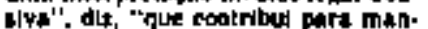

Defesa pede a reduçáno da pená

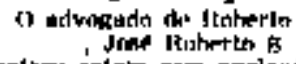

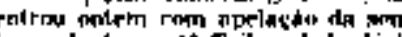

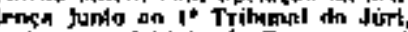

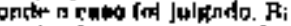
apelaride porquen entendor one "0 jud

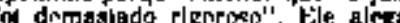

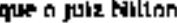

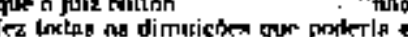
umentor alfm do qun dryeria

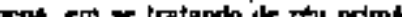

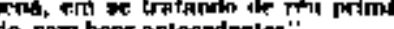

a pens mintma para himoleddlo

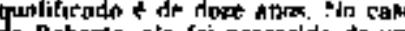
de Roberto. pla fó mcreachda de um erco, codalizandn detrasebs anut. A

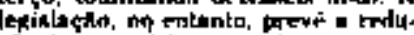

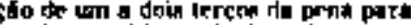
os rews sermi.impulavels. o jus optos

ex a fiecta do tolleliro agtrying" por etuc rexlocínio, o pulbico crado d derilpar a pulmico

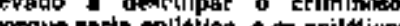

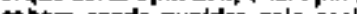

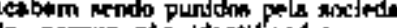

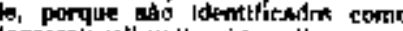
agtest|win" nul "prriknow.

sokundo Istman, Ftimsss que

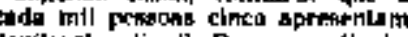
"epilepala ntirn". Por ease edkeulo haveria cerra de seteretpition tril epilellec no Briall. Eubort cries

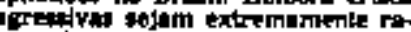

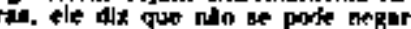

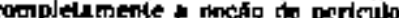

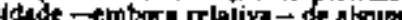

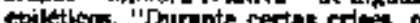
Thikes. Durninte certas crimalo contur cor conter pade ampurar pasea on

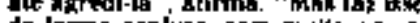

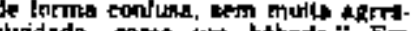
alvidade, crmo um bahondo." Em

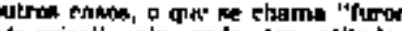
was crime", cle pode In suliudes

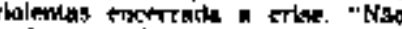
controce rentum cano nue Iroht

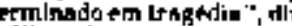

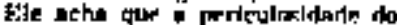

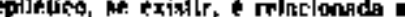

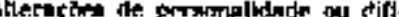

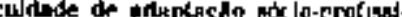
cond, "Frlatertrmente,

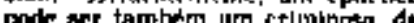

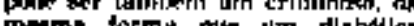

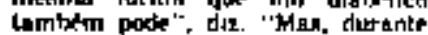

itsminulclo mbnor tum lercio choteodo angim, ara des ancen obto

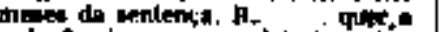

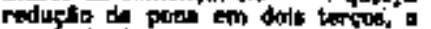

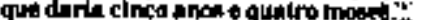

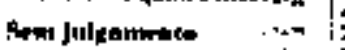

Apropar doc recursoa, por parts do promodor $e$ do advorada, Robetio no. aert levado * porvo jul|pmmento: aprolackn bers examinidn gor un dos Comartes Crimiantd do Totherral de Jualtç, ramtumta por trits denctir arrodow e um prealdent:

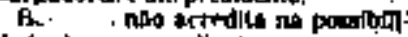
dade de que rety rilirsil portranega clarto. "Ele pode estar nu fin d. Alno que yerr". dle of advitotdo.

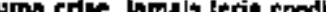
coodicole di oxecurtar o masoscre de luma tomtia atrina," No caso do Paberto elo

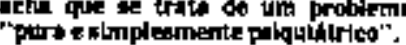

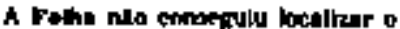

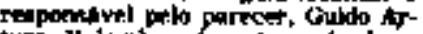

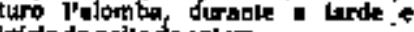
intele de noile de onturm.

Denandancto nave

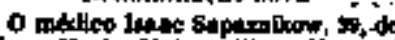
Ner Yot: Metropolltan Houpite ruate supfele de líoplial dal Clint

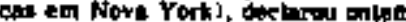

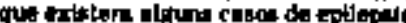
rante rurose deaconhectidat en wire ax homno latre ume descin

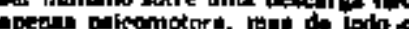

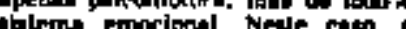

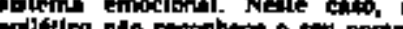

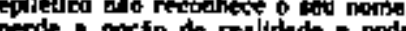

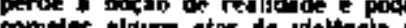

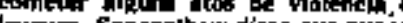

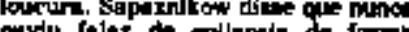

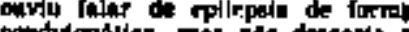
cotchulopalien، mal no deicarita.

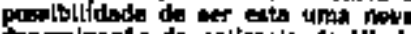

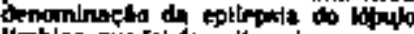

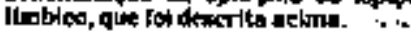

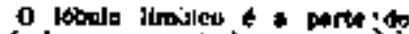
cetrebro que controli in emnodè

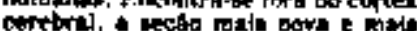

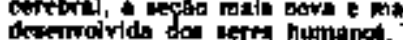

